\title{
ON THE ORIGIN OF SIPHONARIID POLYPROPIONATES: TOTAL SYNTHESIS OF CALOUNDRIN B AND ITS ISOMERIZATION TO SIPHONARIN B
}

\author{
A Thesis Submitted to the \\ College of Graduate Studies and Research \\ In Partial Fulfillment of the Requirements \\ For the Degree of Doctor of Philosophy \\ In the Department of Chemistry \\ University of Saskatchewan \\ Saskatoon
}

By

FABIOLA BECERRIL-JIMÉNEZ

(c) Copyright Fabiola Becerril-Jiménez, February 2012.

All rights reserved. 


\title{
PERMISSION TO USE
}

In presenting this thesis in partial fulfilment of the requirements for a Postgraduate degree from the University of Saskatchewan, I agree that the Libraries of this University may make it freely available for inspection. I further agree that permission for copying of this thesis in any manner, in whole or in part, for scholarly purposes may be granted by the professor or professors who supervised my thesis work or, in their absence, by the Head of the Department or the Dean of the College in which my thesis work was done. It is understood that any copying or publication or use of this thesis or parts thereof for financial gain shall not be allowed without my written permission. It is also understood that due recognition shall be given to me and to the University of Saskatchewan in any scholarly use which may be made of any material in my thesis.

Requests for permission to copy or to make other use of material in this thesis in whole or part should be addressed to:

\author{
The Head \\ Department of Chemistry \\ University of Saskatchewan \\ 110 Science Place \\ Saskatoon, SK S7N 5C9 \\ CANADA
}




\section{ACKNOWLEDGMENTS}

I want to take this opportunity to express all my gratitude to my supervisor Dr. Dale Ward for his guidance during the past five years. You taught me to perceive chemistry from a different perspective. Thank you!

I would like to thank my advisory committee members, Dr. Soledade Pedras, Dr. Marek Majewski, and Dr. Nicholas Low for their suggestions throughout my graduate studies.

Special thanks are given to the Department of Chemistry, University of Saskatchewan, Natural Sciences and Engineering Research Council (NSERC) of Canada for financial support.

I am very thankful to Dr. Keith Brown, Dr. Gabriel Schatte, and Ken Thoms for their technical support.

Special acknowledgments to Dr. Pia Wennek for her support and interest in my teaching development, I had a wonderful time teaching under your supervision!

All my appreciation to Dr. Michel Gravel and his group, in particular to Miss. Karen Thai and Dr. Eduardo Sánchez for those wonderful moments.

I want to thank to all my friends for their support and encouragement especially to Dr. Alfredo Vázquez, Lucille and Francisco Otero, Armando Marenco, Vishal and Jackie Jheengut, Sandip Pardeshi and Nancy Bawa, Gerry and Shirley Falk.

I would like to thank all the former and current members of the Ward group for the enjoyable moments we shared together and the constructive discussions in the lab: Dr. Garrison E. Beye, Dr. Martin Gillis, Dr. Vishal Jheengut, Dr. Sandip Pardeshi, Dr. Jianheng Shen, Pramod Jadhav, Thano Karagiannis, Alieh Kazemeini, Leon Lai, Nikki Theaker, Mojtaba Biniaz, Muxi Cheng, Sushital Jana, Diptarghya Kundu, Jackie Lu, and Mohammad Mehdi (Pooyan) Zahedi.

Foremost, I am really thankful to my parents for their unconditional support and encouragement. I would like to thank Dirceu, Juan, and Nelly for their love and support.

Thank you to my husband Lalo for his support, understanding, patience, and those long waits after hours. 


\section{With all my love to Eduardo Paty and José Luis}




\section{TABLE OF CONTENTS}

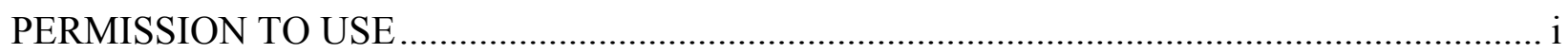

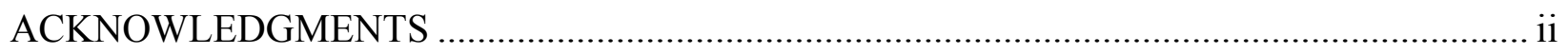

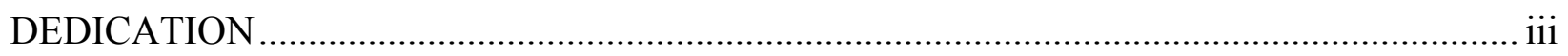

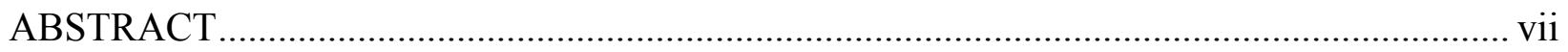

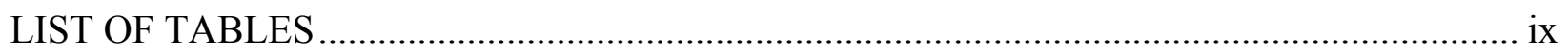

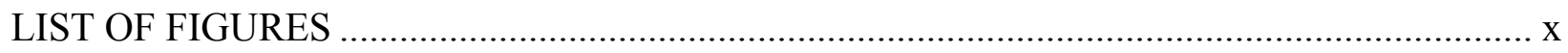

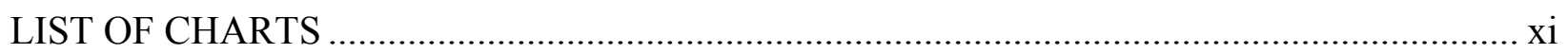

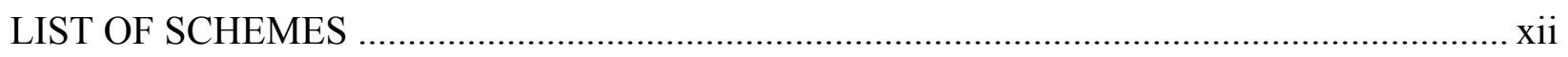

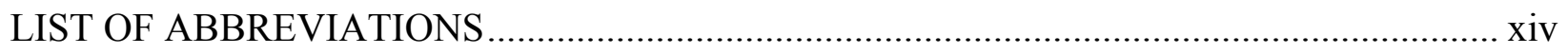

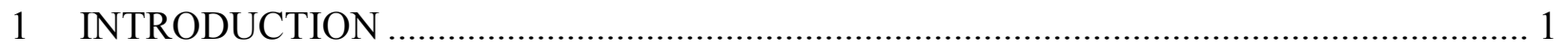

$1.1 \quad$ Polypropionates from Siphonaria zelandica ...................................................................... 1

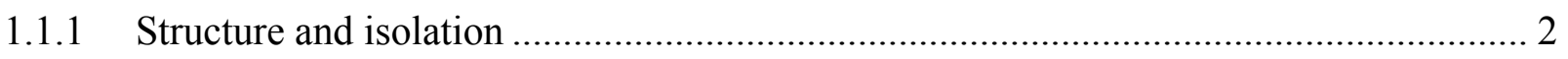

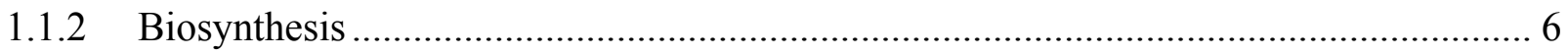

1.1.3 Hypothesis on the origin of siphonariid polypropionates ............................................. 9

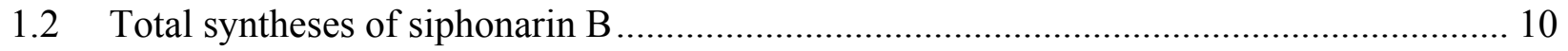

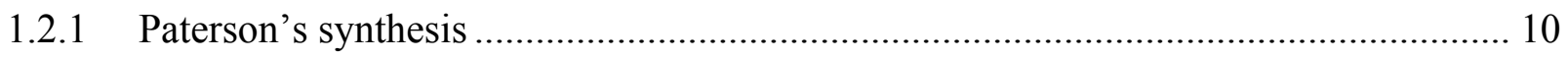

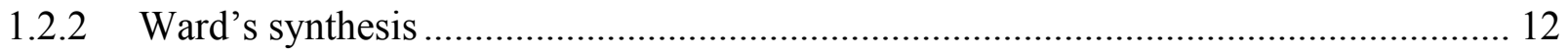

1.2.2.1 Synthesis of siphonarin B from the putative acyclic linear precursor ................... 12

1.2.2.2 Revised hypothesis on the origin of siphonariid polypropionates ......................... 17

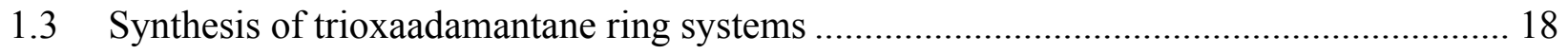

1.3.1 Hoffmann's synthesis of the trioxaadamantane ring system of muamvatin ................. 18 
1.3.2 Paterson's synthesis of muamvatin................................................................ 20

1.3.3 Perkins' approach to Dolabriferol........................................................................ 22

1.3.4 Ward's synthesis of the trioxaadamantane ring systems of muamvatin and caloundrin B

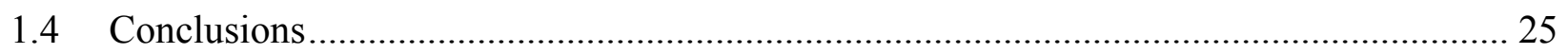

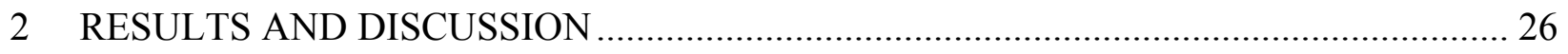

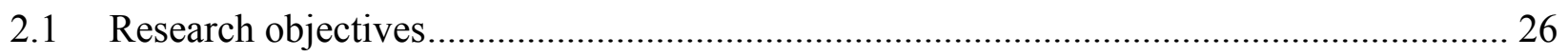

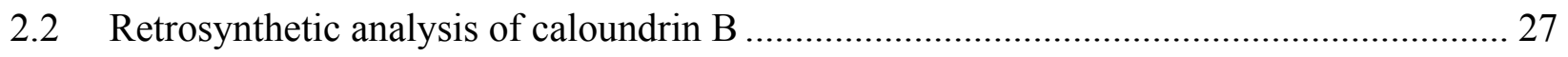

2.3 Formation of the trioxaadamantane ring system of caloundrin B................................ 29

2.3.1 Sulphur-bridged trioxaadamantanes from 5-alkanoyl-3-[hydroxy(4-oxotetrahydro-2Hthiopyran-3-yl)methyl]dihydro-2H-thiopyran-4(3H)-one precursors ...................... 32

2.3.1.1 The isopropyl analogue (from the 5-(2-methylpropanoyl) precursor)................. 32

2.3.1.2 The 3-benzyloxy-2methylpropyl analogue (from the Roche ester)..................... 36

2.3.2 Trioxaadamantanes from 2-substituted 7-hydroxy-4,6,8-trimethylundecane-3,5,9-trione

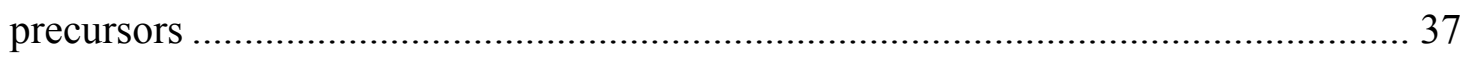

2.3.2.1 7-Hydroxy-2,4,6,8-tetramethylundecane-3,5,9-trione precursor ........................ 37

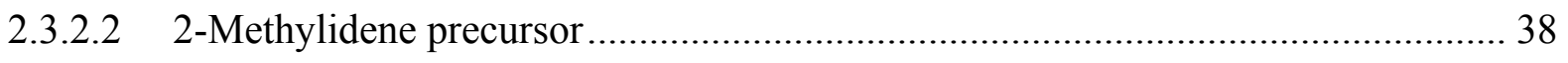

2.3.2.3 2-Benzyloxymethyl precursors (from the Roche ester) .................................... 39

2.3.2.4 2-(4-Benzyloxytetrahydro-2H-thiopyran-3-yl) precursor................................ 45

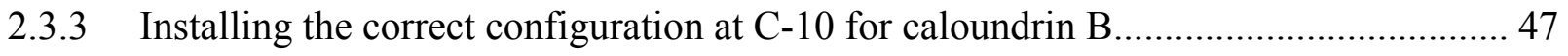

2.4 Application of aldol coupling with kinetic resolution to the synthesis of caloundrin B..... 51

2.4.1 The thiopyran route to polypropionates: design of aldol reactions that proceed with

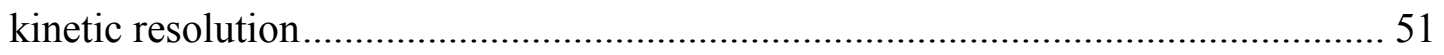


2.4.2 Non-linear effects in the enantiotopic group selectivity of aldol reactions of chiral reactants

2.4.3 Study of the selectivity in the aldol reactions between 3-pentanone and racemic 2-(6ethyl-3,5-dimethyl-4-oxo-4H-pyran-2-yl)propanal ................................................ 56

2.4.4 Study of the stereoselectivity of aldol reactions between the enantiopure trioxaadamantane ketone fragment and the racemic pyrone aldehyde fragment....... 59

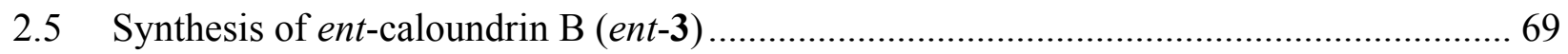

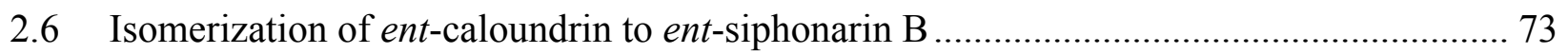

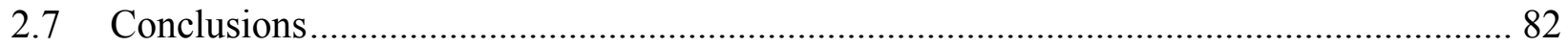

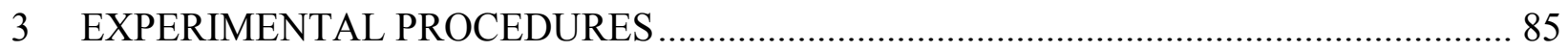

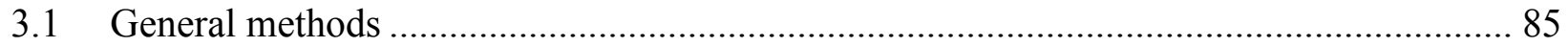

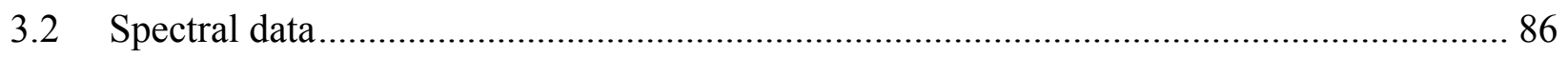

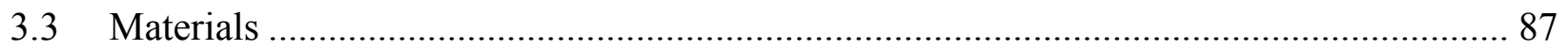

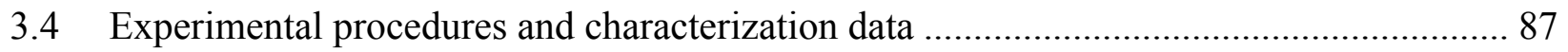

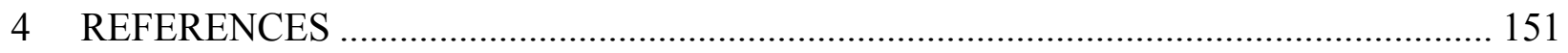




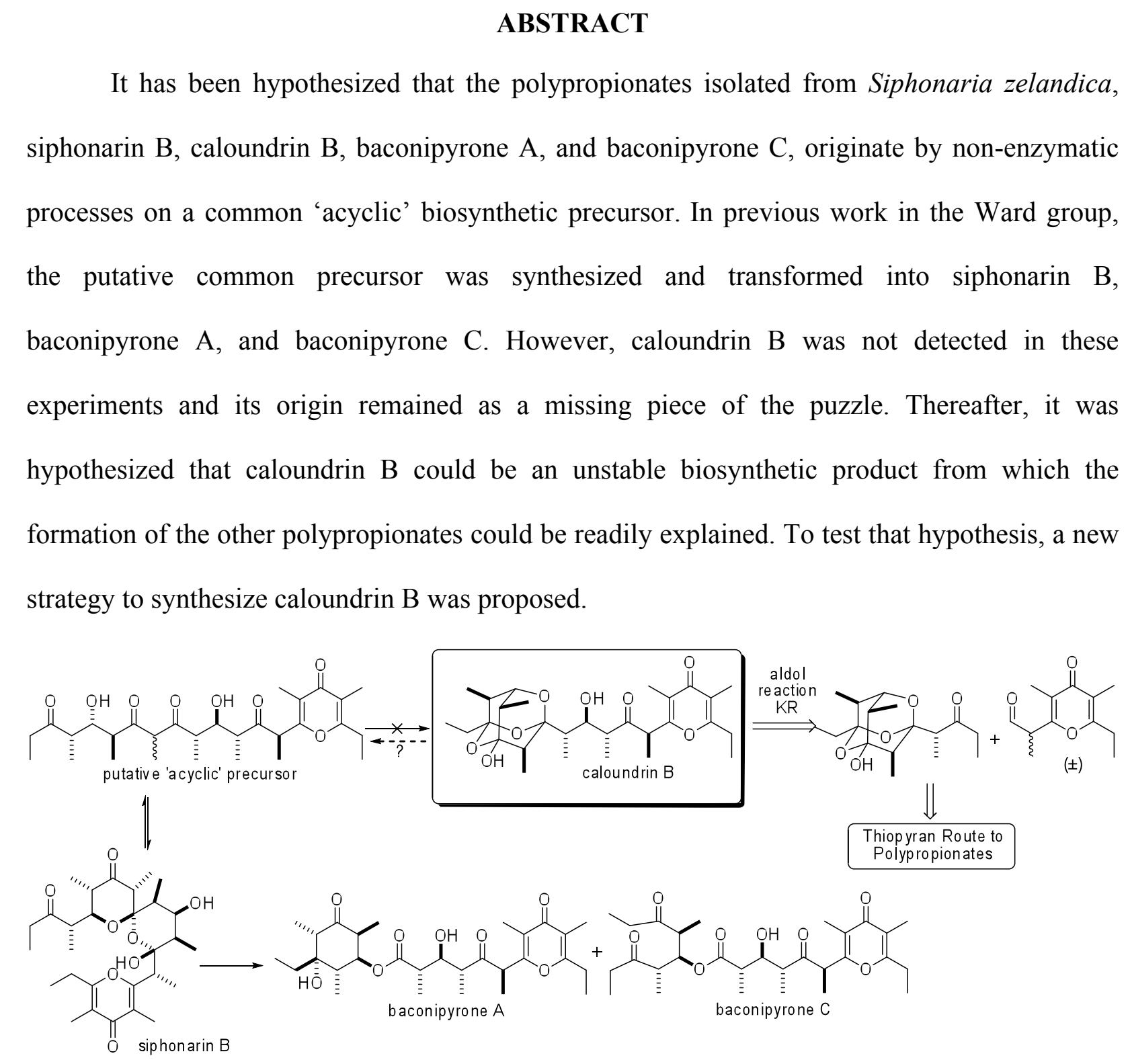

This thesis describes and analyzes the manner in which the first synthesis of entcaloundrin B was achieved. The two key steps towards the target molecule involved the synthesis of the trioxaadamantane motif and the assembly of the complete skeleton of entcaloundrin B via a novel aldol coupling between the trioxaadamantane-containing ketone and the $\gamma$-pyrone-containing aldehyde, that proceeds with kinetic resolution. 
The studies toward the synthesis of caloundrin B allowed the development of new methodologies and the application of a recently disclosed protocol to design aldol reactions that proceed with kinetic resolution. During the course of those studies, a non-linear effect was identified and characterized.

After completion of the synthesis, ent-caloundrin B was isomerized to ent-siphonarin B under thermodynamic conditions, thus confirming the relative and absolute configuration of entcaloundrin B. This transformation leads to the conclusion that caloundrin B is much less stable than siphonarin B; as a consequence, caloundrin B cannot be an artifact of isolation as previously proposed, but instead, it could be the biosynthetic product from which siphonarin B, baconipyrone $\mathrm{A}$, and baconipyrone $\mathrm{C}$ are formed. 


\section{LIST OF TABLES}

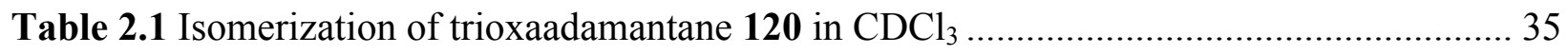

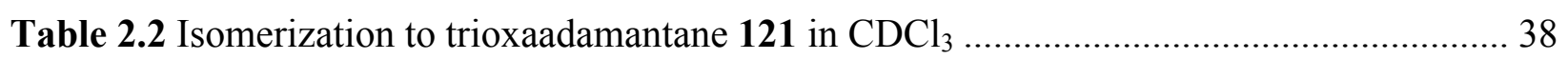

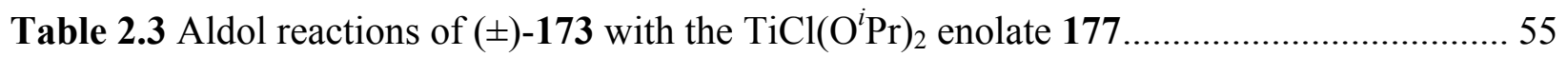

Table 2.4 Aldol reactions between 3-pentanone and racemic 2-(6-ethyl-3,5-dimethyl-4-oxo-4H-

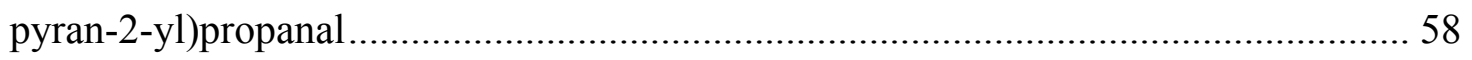

Table 2.5 Comparison of ${ }^{13} \mathrm{C}-\mathrm{NMR}$ chemical shifts of aldol adducts $181,182,183,184$, and 185

Table 2.6 Comparison of ${ }^{1} \mathrm{H}-\mathrm{NMR}$ chemical shifts of aldol adducts $181, \mathbf{1 8 2}, \mathbf{1 8 3}, \mathbf{1 8 4}$, and 185

Table 2.7 Comparison of ${ }^{1} \mathrm{H}-\mathrm{NMR}$ chemical shifts of aldol aducts $181, \mathbf{1 8 2}, \mathbf{1 8 3}, \mathbf{1 8 4}$, 186, and

188 63

Table 2.8 Comparison of ${ }^{1} \mathrm{H}-\mathrm{NMR}$ chemical shifts of aldol aducts $181, \mathbf{1 8 2}, \mathbf{1 8 3}, \mathbf{1 8 4}$, 190, and 192 66

Table 2.9 Comparison of ${ }^{1} \mathrm{H}-\mathrm{NMR}$ chemical shifts of aldol aducts 181, 182, 183, 184, and 19168

Table 2.10 Comparison of ${ }^{1} \mathrm{H}-\mathrm{NMR}$ spectra of natural 3 and synthetic ent-3 ........................ 71

Table 2.11 Comparison of ${ }^{13} \mathrm{C}$-NMR spectra of natural $\mathbf{3}$ and synthetic ent-3........................ 72

Table 2.12 Comparison of ${ }^{1} \mathrm{H}-\mathrm{NMR}$ spectra of natural 2 and synthetic ent-2 ....................... 75

Table 2.13 Comparison of ${ }^{13} \mathrm{C}-\mathrm{NMR}$ spectra of natural 2 and synthetic ent-2 (inverse detection

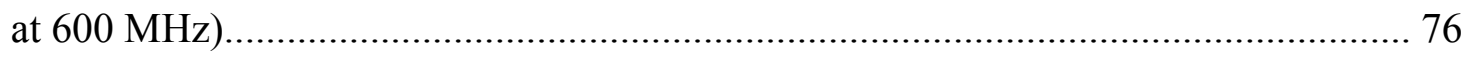

Table 2.14 Comparison of ${ }^{13} \mathrm{C}-\mathrm{NMR}$ spectra of ent-3, ent-14-epi-3, 6, and 14-epi-6 ................ 80 


\section{LIST OF FIGURES}

Figure 1.1 Siphonariid polypropionates isolated from Siphonaria zelandica ........................... 1

Figure 1.2 Assignment of the absolute configuration of 1 and 2 by synthesis of 9 .................. 2

Figure 1.3 Stereochemical comparison of siphonariid polypropionates ................................ 8

Figure 1.4 Hypothesis about the biosynthetic origin of siphonariid polypropionates ................. 9

Figure 1.5 Revised hypothesis on the origin of siphonariid polypropionates.......................... 18

Figure 2.1 Major objectives of the research................................................................ 27

Figure 2.2 Ground state energies for the equilibrium conformer of 146, 10-epi-146, 148, and 10-

epi-148 42

Figure 2.3 Starting materials to prepare trioxaadamantanes 116, ent-116, 10-epi-116, and ent-10epi-116 43

Figure 2.4 Formation of $\mathbf{1 3 4}$ and 10-epi-116 after isomerization with imidazole.................... 45

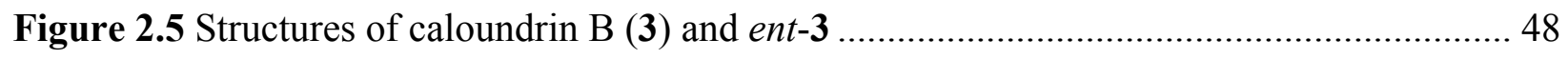

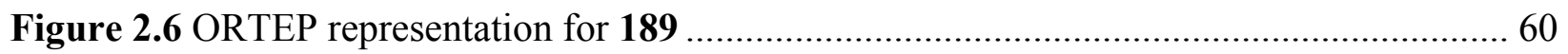

Figure 2.7 ${ }^{1} \mathrm{H}-\mathrm{NMR}$ of the isomerization of ent-3 in a solution of imidazole in $\mathrm{CDCl}_{3}$ at room temperature for 1 day 74

Figure 2.8 HPLC studies for the isomerization of ent-3 in a solution of imidazole in $\mathrm{CH}_{3} \mathrm{CN}$ at room temperature for 8 days 78 


\section{LIST OF CHARTS}

Chart 2.1 Isomerization of trioxaadamantane 120 in $\mathrm{CDCl}_{3}$ 35

Chart 2.2 Comparison of ${ }^{13} \mathrm{C}$-NMR chemical shifts of $\mathbf{1 8 5}$ with those of the model aldol adducts

$(181,182,183$, and 184). 62

Chart 2.3 Comparison of ${ }^{13} \mathrm{C}-\mathrm{NMR}$ chemical shifts of $\mathbf{1 8 8}$ (major compound) with those of the model aldol adducts $(\mathbf{1 8 1}, \mathbf{1 8 2}, \mathbf{1 8 3}$, and 184) 64

Chart 2.4 Comparison of ${ }^{13} \mathrm{C}-\mathrm{NMR}$ chemical shifts of $\mathbf{1 8 6}$ (minor compound) with those of the model aldol adducts $(\mathbf{1 8 1}, \mathbf{1 8 2}, \mathbf{1 8 3}$, and 184) 64

Chart 2.5 Comparison of ${ }^{13} \mathrm{C}-\mathrm{NMR}$ chemical shifts of $\mathbf{1 9 0}$ (minor compound) with those of the model aldol adducts $(\mathbf{1 8 1}, \mathbf{1 8 2}, \mathbf{1 8 3}$, and 184) 66

Chart 2.6 Comparison of ${ }^{13} \mathrm{C}-\mathrm{NMR}$ chemical shifts of 192 (major compound) with those of the model aldol adducts $(\mathbf{1 8 1}, \mathbf{1 8 2}, \mathbf{1 8 3}$, and 184) 67

Chart 2.7 Comparison of ${ }^{13} \mathrm{C}-\mathrm{NMR}$ chemical shifts of 191 (major compound) with those of the model aldol adducts $(\mathbf{1 8 1}, \mathbf{1 8 2}, \mathbf{1 8 3}$, and 184) 69 


\section{LIST OF SCHEMES}

Scheme 1.1 Rationale for the transformation of siphonarins to baconipyrones........................ 3

Scheme 1.2 Proposed cyclization pathways for the two epimers at C-8 of 13 ........................ 5

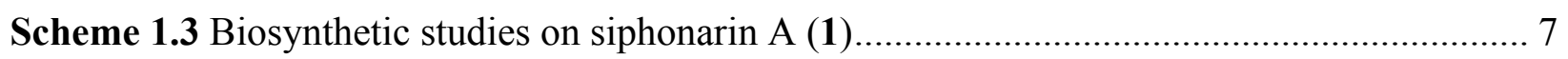

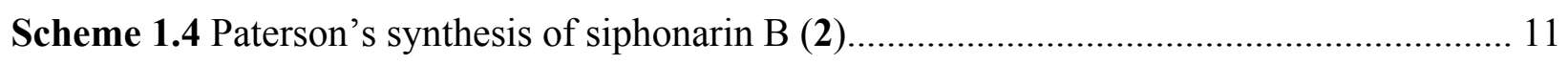

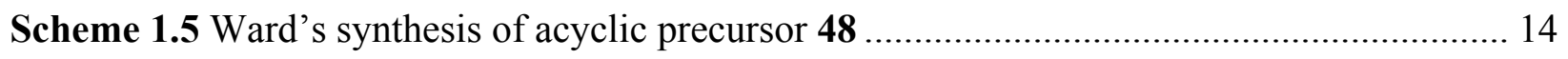

Scheme 1.6 Isomerization of acyclic precursor 48 ...................................................... 16

Scheme 1.7 Model studies to form the trioxaadamantane moiety of muamvatin (19)............... 19

Scheme 1.8 Formation of the trioxaadamantane moiety of muamvatin (19) ......................... 20

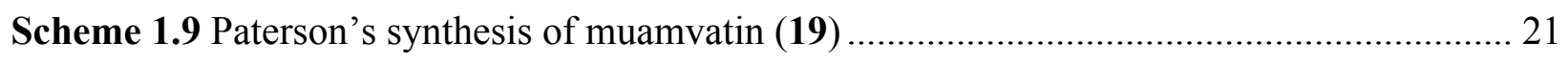

Scheme 1.10 Formation of a trioxaadamantane moiety during Perkin's approach towards the

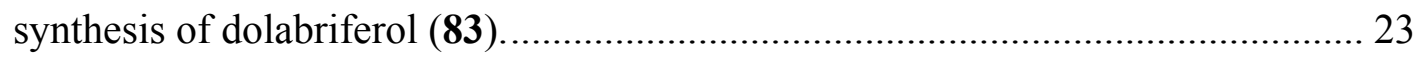

Scheme 1.11 Synthesis of model trioxaadamantanes (58 and 89) from muamvatin (19) and

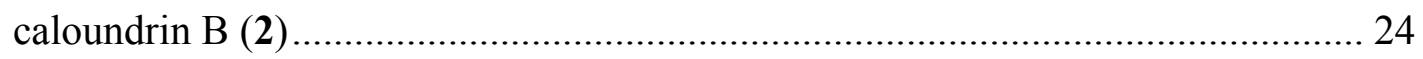

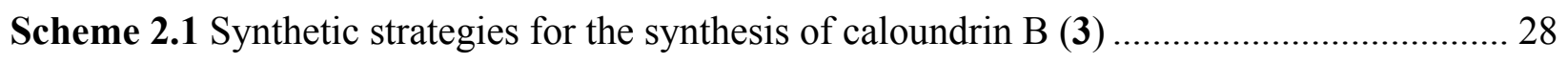

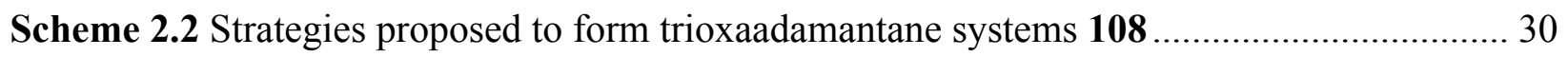

Scheme 2.3 Proposed approaches for the generation of trioxaadamantane systems that would

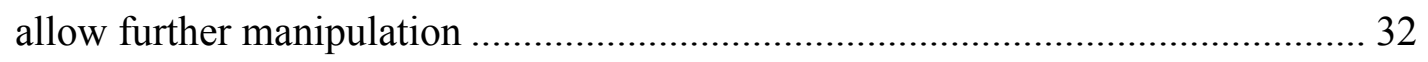

Scheme 2.4 Formation of trioxaadamantane system bearing an isopropyl substituent following

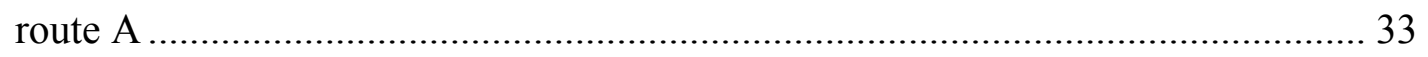

Scheme 2.5 Isomerization of trioxaadamantane $\mathbf{1 2 0}$ to 121 under basic conditions................. 34

Scheme 2.6 Approach to trioxaadamantane 116 from 102 and Roche ester-derived aldehyde 29 36

$$
\text { xii }
$$


Scheme 2.7 Formation of trioxaadamantane system 121 following route B

Scheme 2.8 Approach to a trioxaadamantane system bearing a 2-propenyl substituent.............. 39

Scheme 2.9 Approach to trioxaadamantane 116 from Roche ester-derived aldehyde 29............ 39

Scheme 2.10 Attempts at folding hemiacetal 134 or 144 to the trioxaadamantane system 116 or 145 41

Scheme 2.11 Synthesis of the trioxaadamantane ent-10-epi-116.............................................. 44

Scheme 2.12 Preparation of enantioenriched aldehyde 159.................................................... 46

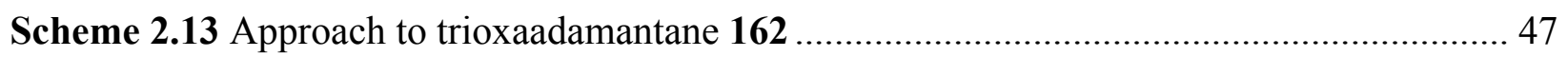

Scheme 2.14 Attempts to invert the configuration at C-10 of ent-10-epi-164 or ent-10-epi-167 49

Scheme 2.15 Preparation of ketones ent-10-epi-95 and ent-95 ............................................. 51

Scheme 2.16 Rational design of aldol reactions with kinetic resolution...................................... 53

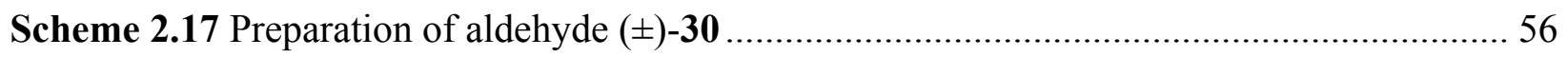

Scheme 2.18 Possible products from the aldol reaction of ent-10-epi-95 and ( \pm )-30, assuming that Felkin aldehyde diastereoface selectivity is favored ........................................ 59

Scheme 2.19 Derivatization of $\mathbf{1 8 5}$ to determine the relative configuration................................ 61

Scheme 2.20 Aldol reaction of enantiopure ent-95 and ( \pm )-30 assuming that Felkin aldehyde

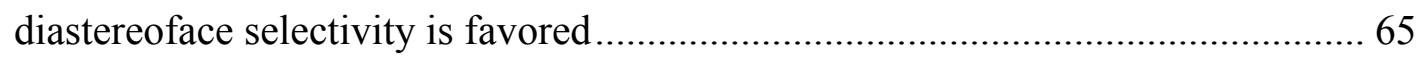

Scheme 2.21 Aldol reactions of ent-95 and $( \pm)$-30 under different conditions.............................. 68

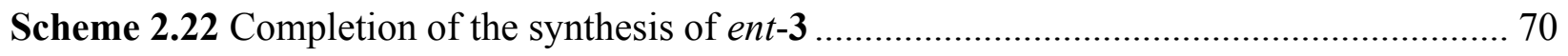

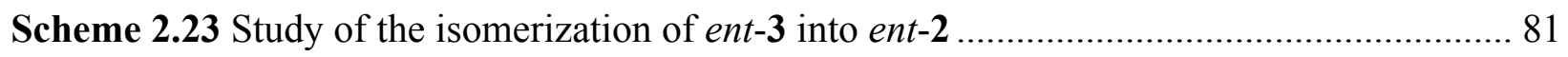




\section{LIST OF ABBREVIATIONS}

$\alpha$

$[\alpha]_{\mathrm{D}}$

Ac

AM1

ap

$\mathrm{aq}$

Ar

9-BBN

$\mathrm{Bn}$

BORSM

$b p$

br

${ }^{t} \mathrm{Bu}$

$\mathrm{Bz}$

${ }^{\circ} \mathrm{C}$

calcd

CI

CIF

$\mathrm{cm}$

COSY observed optical rotation

specific rotation (expressed without units; the actual units,

$(\mathrm{deg} \cdot \mathrm{mL}) /(\mathrm{g} \cdot \mathrm{dm})$, are implied $)$

acetyl

Austin model 1

apparent (spectral)

aqueous

aryl

9-borabicyclo[3.3.1]nonyl

benzyl

based on recovered starting material

boiling point

broad (spectral)

tert-butyl

benzoyl

degres Celsius

calculated

chemical ionization

crystallographic information file

centimeter(s)

correlation spectroscopy 


$\begin{array}{ll}c \text {-Hex } & \text { cyclohexyl } \\ \delta & \text { chemical shift in parts per million } \\ \text { d } & \text { day(s); doublet (spectral) } \\ \text { DBU } & 1,8 \text {-diazabicyclo[5.4.0]undec-7-ene } \\ \text { DCC } & N, N \text { '-dicyclohexylcarbodiimide } \\ \text { DEIPS } & \text { diethylisopropylsilyl } \\ \text { DEPT } & \text { distortionless enhancement by polarization transfer } \\ \text { DIBAL-H } & \text { diisobutylaluminium hydride } \\ \text { DIPEA } & \text { diisopropylethylamine } \\ \text { DMF } & N, N \text {-dimethylformamide } \\ \text { DMP } & \text { Dess-Martin periodinane } \\ \text { DMSO } & \text { dimethyl sulfoxide } \\ \text { dr } & \text { diastereomeric ratio } \\ \text { DRIFT } & \text { diffuse reflectance infrared Fourier transform spectroscopy } \\ \text { ee } & \text { enantiomeric excess } \\ \text { EI } & \text { electron impact } \\ \text { ent } & \text { enantiomer of } \\ \text { epi } & \text { epimer of } \\ \text { ECCuiv } & \text { electrospray ionization } \\ \text { ESI } & \text { ethyl } \\ \text { Felumn } & \end{array}$




$\begin{array}{ll}\text { FTIR } & \text { Fourier transform infrared } \\ \text { g } & \text { gram(s) } \\ \text { h } & \text { hour(s) } \\ \text { HMBC } & \text { heteronuclear multiple bond correlation } \\ \text { HMDS } & \text { hexamethyldisilazane, bis(trimethylsilyl)amide } \\ \text { HPLC } & \text { high-performance liquid chromatography } \\ \text { HRMS } & \text { high resolution mass spectrometry } \\ \text { HSQC } & \text { heteronuclear single quantum correlation } \\ \text { IBX } & \text { 2-iodoxybenzoic acid } \\ \text { IR } & \text { infrared } \\ J & \text { coupling constant (in NMR spectroscopy) } \\ \text { KR } & \text { kinetic resolution } \\ \text { LDA } & \text { lithium diisopropylamide } \\ \text { lit. } & \text { literature value (abbreviation used with period) } \\ \text { LRMS } & \text { mutual kinetic enantioselection } \\ \text { M } & \text { metresolution mass spectrometry } \\ \text { M } & \text { molar (moles per litre) } \\ \text { MKE } & \text { parent molecular ion } \\ \text { MHz } & \text { megahertiplet (spectral) } \\ \text { minute(s) } & \end{array}$




\begin{tabular}{|c|c|}
\hline mol & mole(s) \\
\hline MOM & methoxymethyl \\
\hline $\mathrm{mp}$ & melting point \\
\hline MS & mass spectrometry \\
\hline Ms & methanesulfonyl or mesyl \\
\hline MW & molecular weight \\
\hline$m / z$ & mass-to-charge ratio \\
\hline$v$ & wavenumber \\
\hline NMR & nuclear magnetic resonance \\
\hline NOE & nuclear Overhauser effect \\
\hline ORTEP & oak ridge thermal ellipsoid plot \\
\hline PCC & pyridinium chlorochromate \\
\hline $\mathrm{Pd} / \mathrm{C}$ & palladium on charcoal \\
\hline $\mathrm{PDC}$ & pyridinium dichromate \\
\hline $\mathrm{Ph}$ & phenyl \\
\hline piv & pivaloyl \\
\hline PMA & phosphomolybdic acid \\
\hline PMB & $p$-methoxybenzyl or $p$-methoxyphenylmethyl \\
\hline ppm & part(s) per million \\
\hline PPTS & pyridinium para-toluenesulfonate \\
\hline${ }^{i} \operatorname{Pr}$ & iso-propyl \\
\hline $\operatorname{Pr}$ & propyl \\
\hline
\end{tabular}

xvii 


$\begin{array}{ll}\text { PTLC } & \text { preparative thin-layer chromatography } \\ \text { Py } & \text { pyridine } \\ \text { q } & \text { quartet (spectral) } \\ \text { quant } & \text { quantitative } \\ \text { R } & \text { alkyl substituent } \\ \text { rac } & \text { a prefix to denote racemic } \\ \text { Raney-Ni } & \text { Raney }{ }^{\circledR} \text {-Nickel } \\ \text { R } & \text { retention factor (in chromatography) } \\ \text { rel } & \text { relative } \\ \text { rt } & \text { room temperature } \\ \text { s } & \text { singlet (spectral); second(s) } \\ \text { t } & \text { triplet (spectral) } \\ \text { TAS-F } & \text { tris(dimethylamino)sulfonium difluorotrimethylsilicate } \\ \text { TBAF } & \text { tetrabutylammonium fluoride } \\ \text { TBDMS or TBS } & \text { tert-butyldimethylsilyl } \\ \text { TES } & \text { triethylsilyl } \\ \text { Tf } & \text { trifluoromethanesulfonyl } \\ \text { TFA } & \text { trifluoroacetic acid } \\ \text { TFAA } & \text { trifluoroacetic anhydride } \\ \text { THF } & \end{array}$


TMS

TOF

Ts

$\mathrm{v} / \mathrm{v}$

wt trimethylsilyl

time-of-flight (in mass spectrometry)

tosyl (para-toluenesulfonyl $\left[p-\mathrm{CH}_{3}-\mathrm{C}_{6} \mathrm{H}_{4}-\mathrm{SO}_{2}\right]$ )

volume per unit volume (volume-to-volume ratio)

weight 


\section{INTRODUCTION}

\section{CHAPTER 1}

\subsection{Polypropionates from Siphonaria zelandica}

Marine polypropionates have been poorly studied and very little is known about their biological activity or role in the chemical ecology of the producing organisms. ${ }^{1,2}$ The main difficulties are that only very small amounts of material are available by extraction of marine organisms (e.g., mollusks) and, in many cases, the isolated compounds are thought not to be genuine biosynthetic products but rather artifacts of isolation.

Marine pulmonates of the genus Siphonaria, also known as false limpets, are intertidal airbreathing mollusks that are a rich source of polypropionates. ${ }^{3}$ For example, the decapropionates siphonarins A (1) and B (2), baconipyrones A (4), B (5), C (6) and D (7) and caloundrin B (3), have been isolated from Siphonaria zelandica (Figure 1.1). ${ }^{4}$

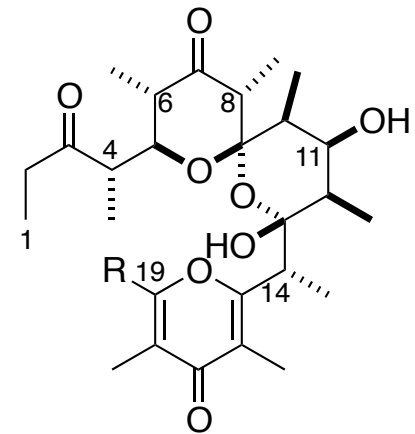

siphonarin $A(1), R=M e$ siphonarin $B(2), R=E t$

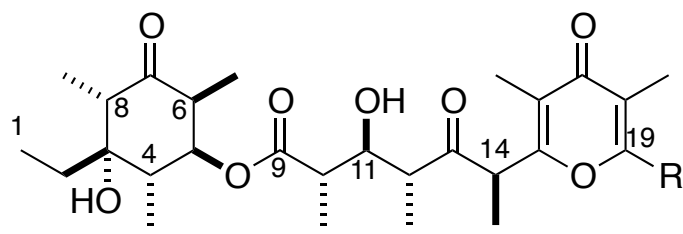

baconipyrone $A(4), R=E t$ baconipyrone $\mathrm{B}(\mathbf{5}), \mathrm{R}=\mathrm{Me}$

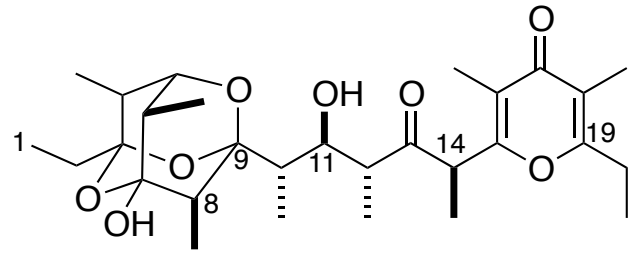

caloundrin B (3)

Figure 1.1 Siphonariid polypropionates isolated from Siphonaria zelandica. 


\subsubsection{Structure and isolation}

In 1984, Faulkner et al. reported the isolation of siphonarin A (1) and siphonarin B (2) from Siphonaria zelandica collected in the intertidal zone along the coast of New South Wales, Australia, with a yield of ca. $0.05 \mathrm{mg}$ of each siphonarin/animal. ${ }^{5}$ The structure and relative configuration of siphonarin A (1) was determined by spectroscopic and X-ray analysis. The homologue siphonarin B (2) has an ethyl rather than a methyl group at C-19 and was assigned the same relative configuration as in $\mathbf{1}$ by analogy. In 1994, Garson et al. determined the absolute configuration of $\mathbf{1}$ by X-ray analysis of its $p$-bromophenylboronate derivative. ${ }^{6}$ Contemporaneously, Paterson et al. were able to assign the absolute configuration of siphonarins $\mathbf{1}$ and $\mathbf{2}$ by enantioselective synthesis of the $\gamma$-pyrone acid $\mathbf{9}$, a degradation product isolated with dihydrosiphonarin B (8) (Figure 1.2). ${ }^{7}$ Subsequently, the total syntheses of siphonarin B (2) by Paterson et al. ${ }^{8}$ and Beye and Ward, ${ }^{9}$ confirmed the absolute configuration of $\mathbf{1}$ and $\mathbf{2}$.<smiles>CCc1oc([C@H](C)[C@@]2(O)O[C@@]3(OC2[C@@H](C)C(O)CC)[C@@H](C)C(C)C(O)[C@@H]3C)c(C)c(=O)c1C</smiles><smiles>CCc1oc(C(C)C(=O)[C@H](C)[C@H](O)[C@H](C)C(=O)O)c(C)c(=O)c1C</smiles><smiles>C=CC(=O)C(C)C(=O)COS(=O)(=O)C(C)C(=O)CC[C@@H](C)c1oc(CC)c(C)c(=O)c1C</smiles>

Figure 1.2 Assignment of the absolute configurations of 1 and 2 by synthesis of 9. 
The isolation of the baconipyrones 4-7 from specimens of Siphonaria baconi ${ }^{*}$ collected at the intertidal zone near Melbourne, Australia (Figure 1.1) was reported in 1989 by Faulkner et al. ${ }^{10}$ The amounts isolated for each compound were: $\mathbf{4}, 0.05 \mathrm{mg} / \mathrm{animal} ; \mathbf{5}, 0.046 \mathrm{mg} / \mathrm{animal} ; \mathbf{6}$, $0.016 \mathrm{mg} /$ animal; 7, $0.046 \mathrm{mg} / \mathrm{animal}$; and $\mathbf{1}, 0.008 \mathrm{mg} / \mathrm{animal}$. The structure and relative configuration of baconipyrone B (5) was determined by X-ray analysis and showed that the configurations at C-4, C-6, C-10, C-11, C-12, and C-14 were identical to those of siphonarin A (1) (Figure 1.1). In contrast to $\mathbf{1}, \mathbf{2}$, and $\mathbf{3}$, the baconipyrones do not contain a contiguous carbon skeleton of polypropionate units. Due to the stereochemical similarities between the siphonarins and baconipyrones, Faulkner et al. ${ }^{10}$ suggested that baconipyrones A (4) and B (5) are generated from siphonarins A (1) and B (2), respectively, via a retro-Claisen reaction (Scheme 1.1).

Scheme 1.1 Rationale for the transformation of siphonarins to baconipyrones.
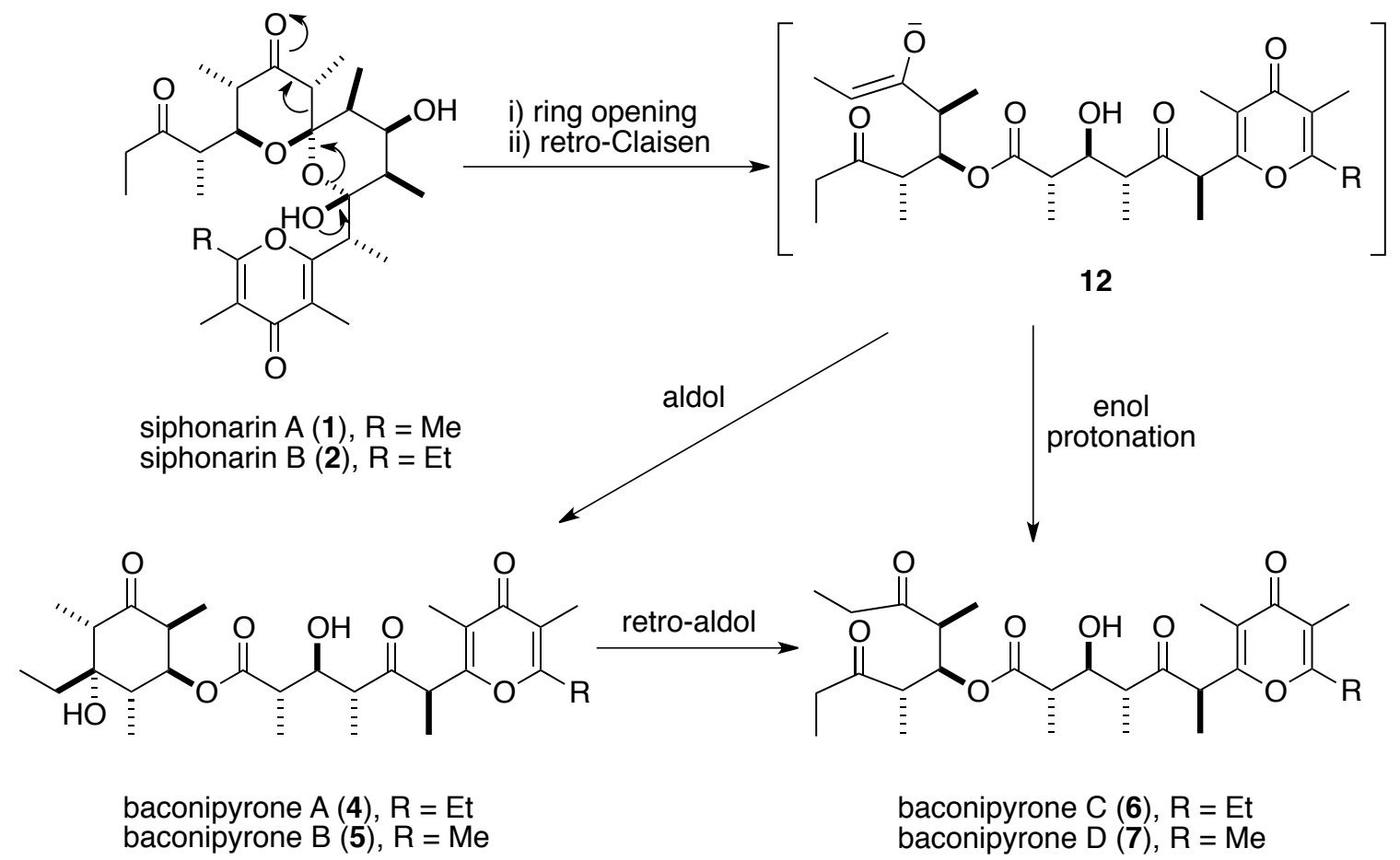

\footnotetext{
${ }^{*}$ Siphonaria baconi is considered synonymous with Siphonaria zelandica
} 
Thus, Faulkner et al. ${ }^{10}$ hypothesized that ring opening of siphonarins $\mathbf{1}$ or $\mathbf{2}$ followed by a retro-Claisen reaction would produce enolate $\mathbf{1 2}$ (Scheme 1.1). Subsequent protonation of $\mathbf{1 2}$ would produce baconipyrones C (6) or D (7), while a stereoselective intramolecular aldol reaction on 12 would afford baconipyrones A (4) or B (5). Additionally, 4 or 5 might produce 6 or 7 , respectively, via a retro-aldol reaction. Based on the proposed mechanistic rationale, the authors suggested that the relative configuration at the stereogenic centres in baconipyrones $\mathrm{C}$ (6) and D (7) are identical to those in baconipyrones A (4) and B (5).

After a careful extraction from S. baconi, Garson et al. did not observe the presence of any baconipyrones (4-7). This observation suggested that the baconipyrones could be artifacts formed during metabolites extraction and isolation. ${ }^{11}$

In 2000, Paterson et al. achieved the total synthesis of baconipyrone C (6) demonstrating that its absolute configuration corresponded with the independently reported siphonarins $\mathbf{1}$ and 2. ${ }^{12}$ The synthesis of $\mathbf{6}$ also corroborate previous studies where the absolute configuration of siphonarins 1 and 2 and baconipyrones 4-7 was confirmed through the synthesis of the $\gamma$-pyrone acid 9 (Figure 1.2). ${ }^{7}$ Baconipyrone C (6) has also been synthesized by Gillingham and Hoveyda ${ }^{13}$ and Yadav and coworkers; ${ }^{14}$ more recently, Beye and Ward synthesized $\mathbf{4}$ and $\mathbf{6}$ from its putative acyclic precursor. ${ }^{9}$

In 1994, Garson and coworkers reported the isolation of caloundrin B (3) $(1.6 \mathrm{mg})$ together with siphonarins A (1) and B (2) from 160 specimens of S. zelandica collected from rock platforms at Caloundra, Australia. ${ }^{15}$ The structure of caloundrin B (3) was deduced by spectroscopic methods providing strong evidence for the presence of a $\gamma$-pyrone and the trioxaadamantane motif with the indicated relative configuration. The C-12 to C-21 fragment seemed to match with the same fragment present in baconipyrone C (6) (Figure 1.1). However, 
the relative configuration along the chain $(\mathrm{C}-10$ to $\mathrm{C}-14)$ and the overall absolute configuration of caloundrin B (3) were assigned based on the presumed relationship with the co-metabolite siphonarin B (2). These isomers were hypothesized to originate from a common intermediate (Scheme 1.2).

Apparently, the trioxaadamantane moiety in caloundrin B (3) was not stable and the isolated sample decomposed during the studies. Attempts to re-isolate $\mathbf{3}$ or isomerize siphonarin B (2) under acidic conditions to produce 3 were unsuccessful. ${ }^{15}$ To date, there have been no further reports of isolation of caloundrin B (3) nor has its total synthesis been disclosed. Therefore, the proposed relative and absolute configuration of $\mathbf{3}$ as well as the presumed link between 3, siphonarin B (2) and baconipyrones A (4) and C (6) through a common acyclic precursor remain as hypotheses.

Scheme 1.2 Proposed cyclization pathways for the two epimers at C-8 of $\mathbf{1 3}$.
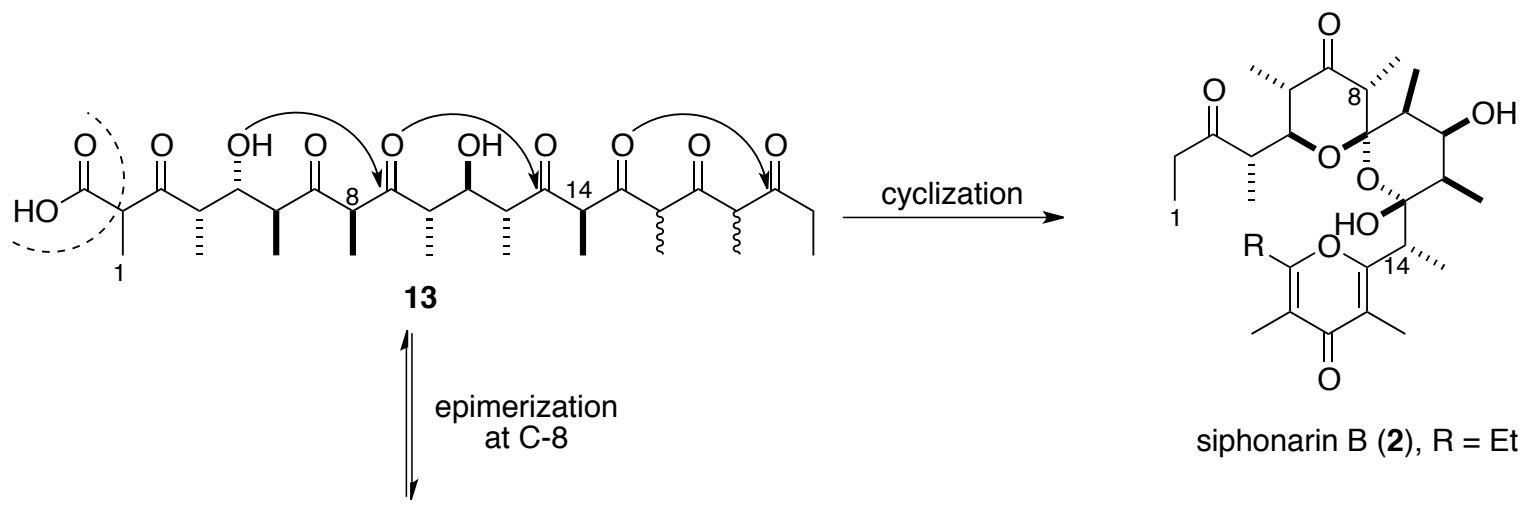

siphonarin $B(2), R=E t$

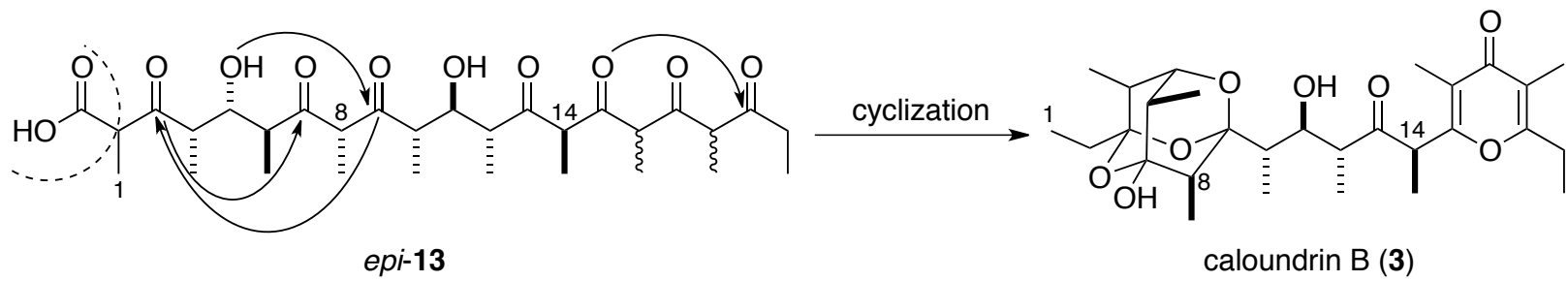




\subsubsection{Biosynthesis}

In 1990, Manker, Garson, and Faulkner studied the biosynthesis of the siphonariids denticulatin A (21) and denticulatin B (10 epi-21) isolated from Siphonaria denticulata (Figure 1.3). ${ }^{16}$ The studies revealed that these metabolites arose from condensation of propionate-derived units similar to the biosynthesis of macrolide ${ }^{17}$ and polyether antibiotics. ${ }^{18}$ Some years later, Garson et al. studied the biosynthesis of siphonarins A (1) and B (2). ${ }^{6}$ Similar to the previous observations on denticulatin A (21), incorporation of ${ }^{14} \mathrm{C}$ in $\mathbf{1}$ and $\mathbf{2}$ was observed after injection of $\left[1-{ }^{14} \mathrm{C}\right]$ propionate to the foot tissue of Siphonaria zelandica. Therefore, they suggested that $\mathbf{1}$ is formed from one acetate and nine propionate units, whereas $\mathbf{2}$ would come from ten propionate units. In order to determine the direction of the chain assembly in $\mathbf{1}$, they studied the biosynthetic origin of C-19. After degradation of ${ }^{14} \mathrm{C}$-labeled 1 via ozonolysis and derivatization with $p$ $\mathrm{Br}\left(\mathrm{C}_{6} \mathrm{H}_{4}\right) \mathrm{COCH}_{2} \mathrm{Br}$, they obtained unlabeled $p$-bromophenacyl acetate coming from $\mathrm{C}$ - 19 . This result is consistent with a chain assembly from C-19 to C-1, as described in pathway A (Scheme $1.3) .^{6}$ 
Scheme 1.3 Biosynthetic studies on siphonarin A (1).

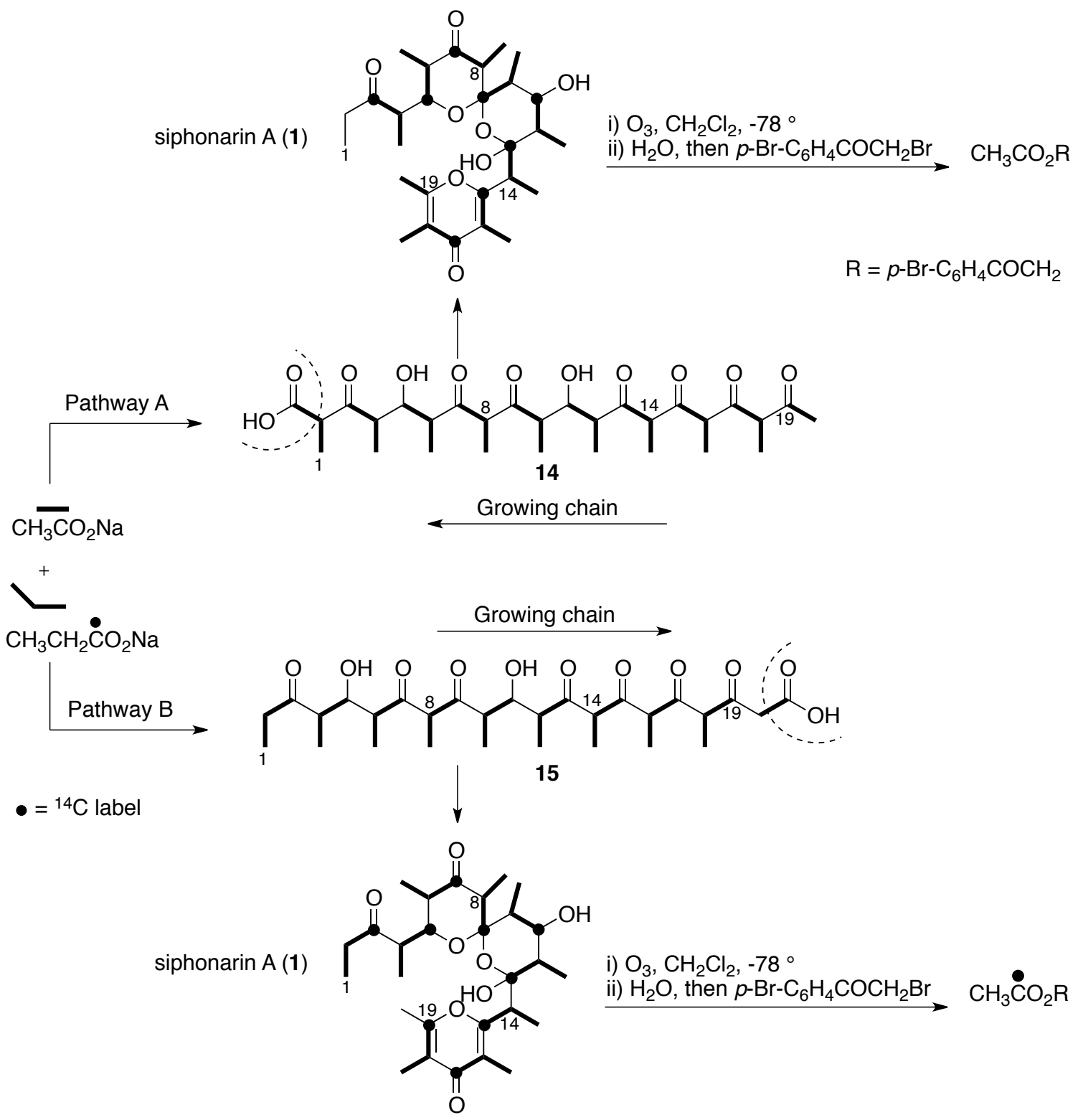

In addition to the biosynthetic studies, Garson et al. compared the relative configurations of the uncyclized tautomers of siphonarins $\mathbf{1}$ and 2, muamvatin (19), and denticulatin A (21). ${ }^{19}$ This comparison revealed a common tetrapropionate unit among these polypropionates. Interestingly, this tetrapropionate unit also matched with the PAPA model proposed by Cane- 
Clemer-Westley ${ }^{\dagger}$ for the biosynthesis of polyether antibiotics (Figure 1.3).$^{18}$ Therefore, it was suggested that siphonariid polypropionates might share a common genetic origin with polyether antibiotics. There were also similarities between the siphonarins and the Celmer macrolide model. ${ }^{17,20}$

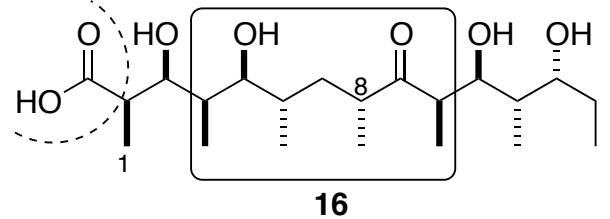

Celmer model for the biosynthesis of macrolides

16<smiles>[R]c1oc([C@H](C)[C@]2(O)O[C@]3(OC([C@H](C)C(=O)CI)[C@@H](C)C(=O)[C@H]3C)[C@H](C)C(O)[C@@H]2C)c(C)c(=O)c1C</smiles>
siphonarin $A(1), R=M e$ siphonarin $B(2), R=E t$

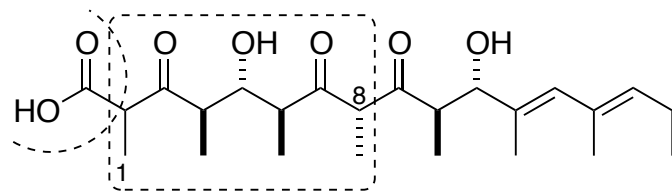

18

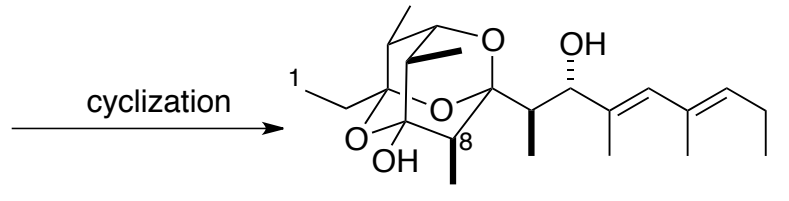

muamvatin (19)

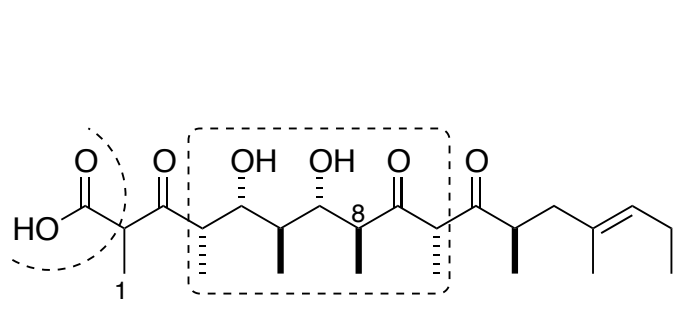

20

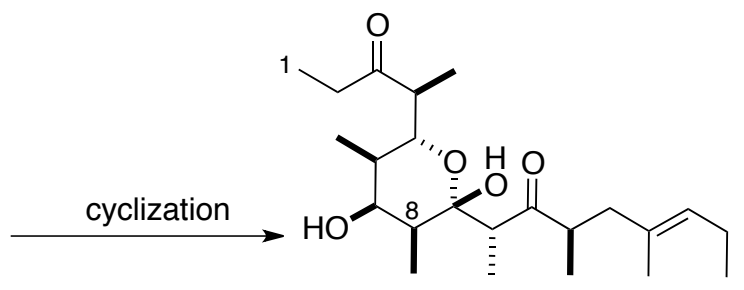

denticulatin A (21)

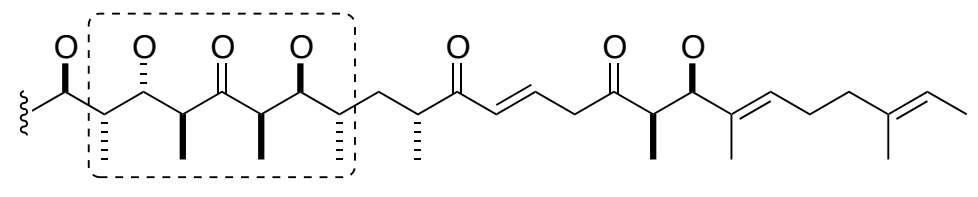

Cane-Celmer-Westley PAPA model for the biosynthesis of polyethers

Figure 1.3 Stereochemical comparison of siphonariid polypropionates

\footnotetext{
${ }^{\dagger}$ PAPA model (Propionate-Acetate-Propionate-Acetate units) is one of the empirical models used as a guide to assign the structure and stereochemistry of polyethers.
} 


\subsubsection{Hypothesis on the origin of siphonariid polypropionates}

Based on the structural, stereochemical, and biosynthetic studies developed on the siphonariid polypropionates $\mathbf{1}$ and $\mathbf{2}$, it was hypothesized that siphonarin B (2), caloundrin B (3), and baconipyrones $\mathrm{A}(4)$ and $\mathrm{C}(\mathbf{6})$ originated via non-enzymatic processes from a common 'acyclic' biosynthetic precursor (23). ${ }^{11,15,20}$ Considering that C-8 in $\mathbf{2 3}$ is stereochemically labile via keto-enol tautomerism, one epimer would produce siphonarin B (2) and the other would generate caloundrin B (3). In addition, the baconipyrones 4 and 6 could be artifacts of isolation coming from rearrangements on $2 .^{11}$

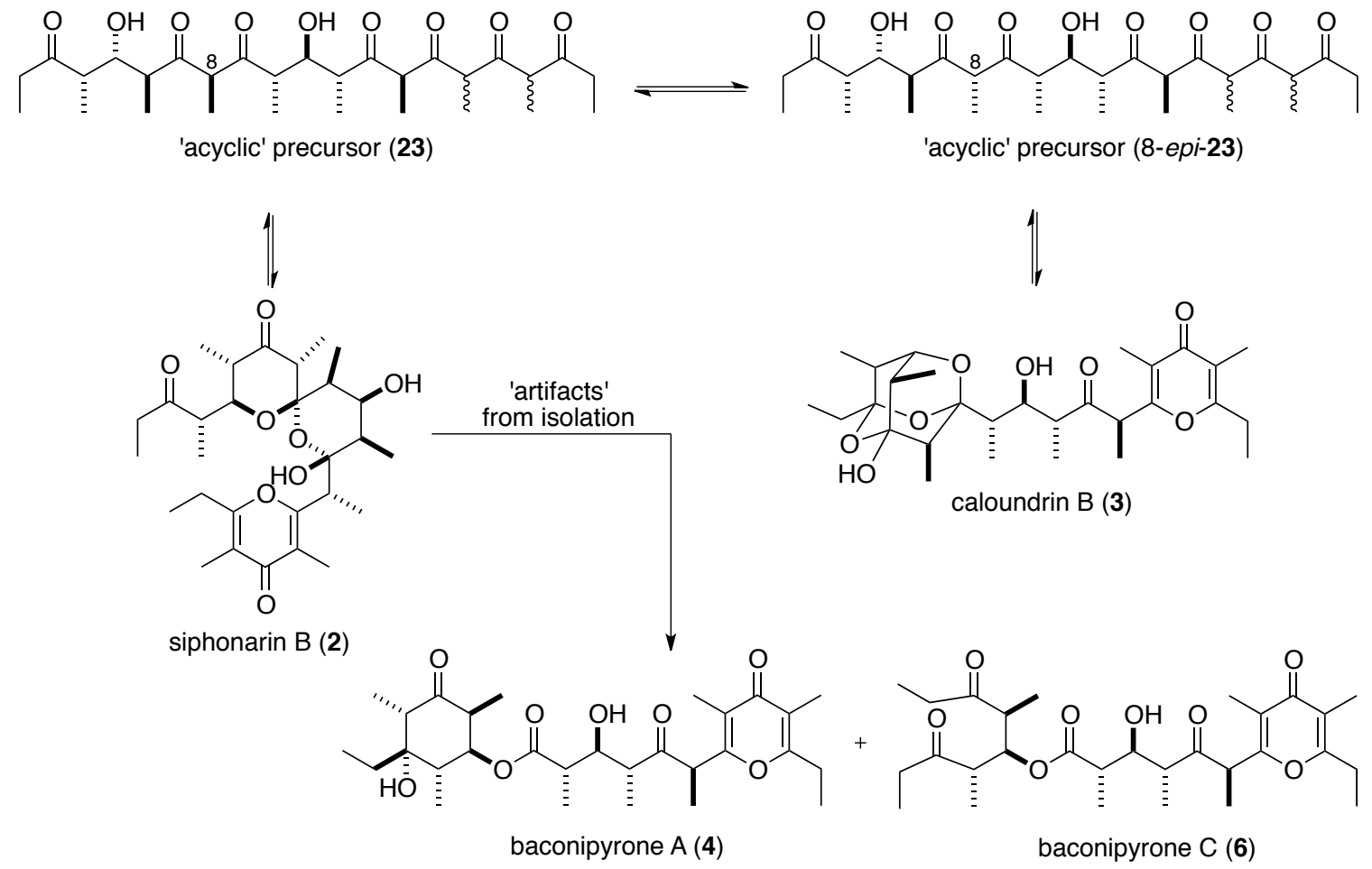

Figure 1.4 Hypothesis about the biosynthetic origin of siphonariid polypropionates 


\subsection{Total syntheses of siphonarin B}

\subsubsection{Paterson's synthesis}

The approach for the synthesis of siphonarin B by Paterson et al. involved coupling of the two main fragments $\mathbf{2 6}$ and $\mathbf{3 3}$ via an aldol reaction producing a protected acyclic precursor $\mathbf{3 4 ,}$ which required the introduction of an ethyl group and functional group manipulations to generate siphonarin B (Scheme 1.4). ${ }^{8}$ The preparation of the keto fragment 26 started with the synthesis of ketone $24\left(\geq 97 \%\right.$ ee) from the $(R)$-Roche ester in 59\% yield over 3 steps. $^{21}$ A boron mediated aldol reaction of $\mathbf{2 4}$ with propionaldehyde followed by an in situ syn reduction provided diol $\mathbf{2 5}$ in $86 \%$ yield and $>95: 5 \mathrm{dr}^{22}$ Diol 25 was bis-DEIPS protected, hydrolyzed at the least hindered position, and then oxidized to produce the DEIPS protected ketone $\mathbf{2 6}$ in $49 \%$ yield over 3 steps. The pyrone containing aldehyde fragment $\mathbf{3 3}$ was prepared from the $(S)$-Roche aldehyde $49 \%$ yield over 8 steps. $^{7,12}$ A Sn(II) mediated aldol reaction of 33 with the TIPS protected ketone 28 gave 31 in 59\% yield. Functional group manipulations on 31 (i.e., Evans-Tishchenko reduction, ${ }^{23}$ PMB protection, TIPS and acetyl removal) produced diol 32. ${ }^{7,12}$ Aldehyde 33 was obtained after bis-TMS protection of diol 32, followed by selective deprotection of the primary alcohol, and oxidation.

Aldol coupling of $\mathbf{3 3}$ with $\mathbf{2 6}$ via its $\mathrm{Sn}(\mathrm{II})$ enolate produced a mixture of three aldol diastereomers in $92 \%$ yield. Removal of the TMS protecting group and Swern oxidation produced 34 and 8-epi-34, which after DEIPS deprotection, furnished hemiacetal 35. Interestingly, when hemiacetal $\mathbf{3 5}$ was exposed to mildly acidic (i.e., $\mathrm{SiO}_{2}$ ) or basic conditions, it underwent a retro-Claisen reaction producing a fragment similar to baconipyrone $\mathrm{C}(\mathbf{6})$. This observation strongly supported the hypothesis that the baconipyrones are rearranged products from siphonarins ${ }^{10}$ or artifacts from isolation as Ireland and Garson had proposed. ${ }^{11,20}$ 
Scheme 1.4 Paterson's synthesis of siphonarin B (2).

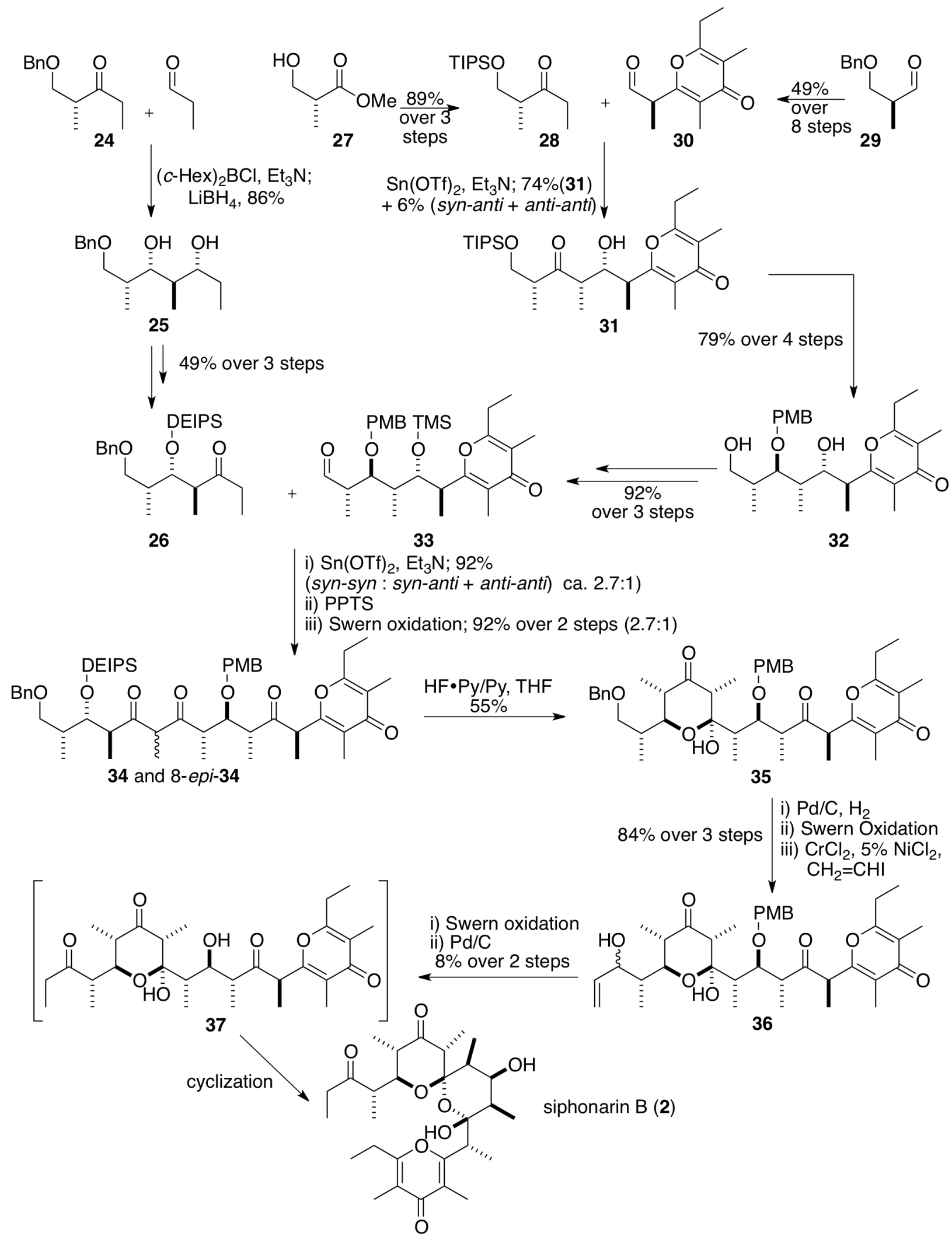


Careful removal of the Bn group on 35, followed by oxidation and introduction of a vinyl group employing the Kishi-Nozaki conditions $\left(\mathrm{CrCl}_{2}, 5 \% \mathrm{NiCl}_{2}, \mathrm{DMF}\right)^{24,25}$ provided compound 36, which was then oxidized and hydrogenated to afford siphonarin B (2) in low yield. Interestingly, caloundrin B (3) was not observed as a product in the final cyclization process. Siphonarin B (2) was synthesized in 25 linear steps from the Roche aldehyde 29 in $0.8 \%$ overall yield.

\subsubsection{Ward's synthesis}

\subsubsection{Synthesis of siphonarin B from the putative acyclic linear precursor}

Ward et al. developed a strategy for the preparation of $\mathbf{4 8}$, the putative acyclic precursor of the siphonariid polypropionates 1-5. ${ }^{9}$ In contrast with Paterson's synthesis, ${ }^{8}$ this approach involved the construction of the complete carbon skeleton prior to cyclization. Because the formation of $\gamma$-pyrones from cyclization of $\beta$-triketides requires special conditions, ${ }^{26-28}$ it was considered unlikely that pyrone formation could occur during the isolation process. Therefore, the $\gamma$-pyrone motif was installed in the acyclic precursor. The synthesis of $\mathbf{4 8}$ allowed studying its cyclization under different conditions thereby directly testing the previous hypotheses about the origin of $2,3,4$, and 6 .

The synthesis of $\mathbf{4 8}$ commenced with the readily available starting materials 38 and $\mathbf{4 4}$ prepared via the thiopyran route to polypropionates extensively studied in the Ward group (Scheme 1.5). ${ }^{29}$ The $\gamma$-pyrone was constructed by a sequence where $\mathbf{3 8}$ was protected and desulfurized followed by aldol reaction of the resulting ketone $\mathbf{3 9}$ with aldehyde $\mathbf{4 0}$. The aldol adduct was oxidized to produce the desired $\gamma$-pyrone 41; however, the reaction conditions also induced hydrolysis of the acetal and elimination of the pivaloate. To reinstall the required stereogenic centre at C-5" in $\mathbf{4 1}$, diastereoselective Luche reduction and $O$-benzyl protection of 
the formed alcohol was followed by oxymercuration ${ }^{30,31}$ producing diol $\mathbf{4 2}$. Taking advantage of the resistance of the secondary alcohol in $\mathbf{4 2}$ to react with triethylsilyl triflate (TESOTf), the primary alcohol was selectively TES-protected, followed by MOM protection of the secondary alcohol. Subsequent removal of the silyl group and oxidation of the resulting alcohol produced the aldehyde 43 which then was coupled with the enantioenriched ketone 44 ( $>98 \%$ ee) via its Ti(IV) enolate to give adduct 45 in $79 \%$ yield and $>20: 1$ dr. Simple functional group manipulations on $\mathbf{4 5}$ produced the desired acyclic precursor $\mathbf{4 8}$, which existed as a complex mixture of keto-enol and ring-chain tautomers with the three hemiacetal forms $\mathbf{4 9 ,} \mathbf{5 0}$, and $\mathbf{5 1}$ or $\mathbf{5 2}$ predominating. The synthesis of $\mathbf{4 8}$ was achieved in 18 linear steps with an overall yield of $3.1 \%$. 
Scheme 1.5 Ward's synthesis of acyclic precursor 48.

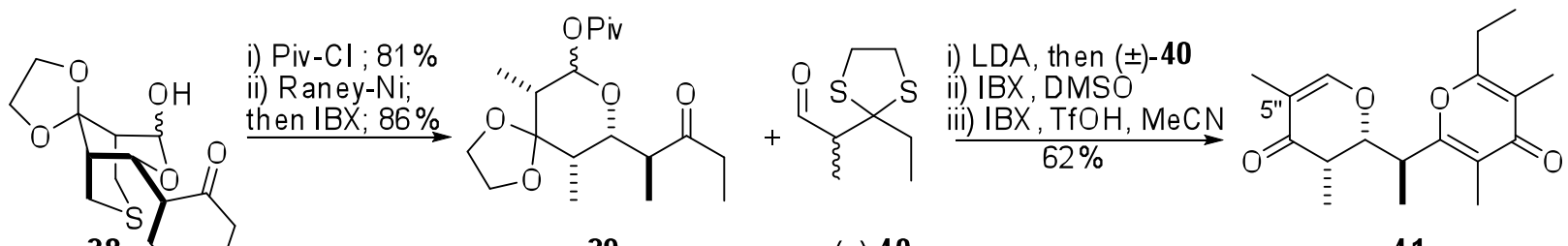

38

39

$( \pm)-40$

$\uparrow_{\mathrm{OMe} \longrightarrow} \longrightarrow$

(1)

$\mathrm{TiCl}_{4}$, DIPEA

$79 \%(d r>20: 1)$

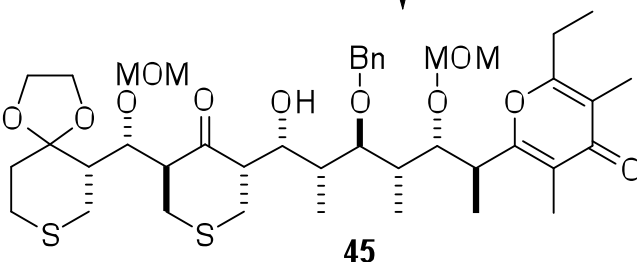

45
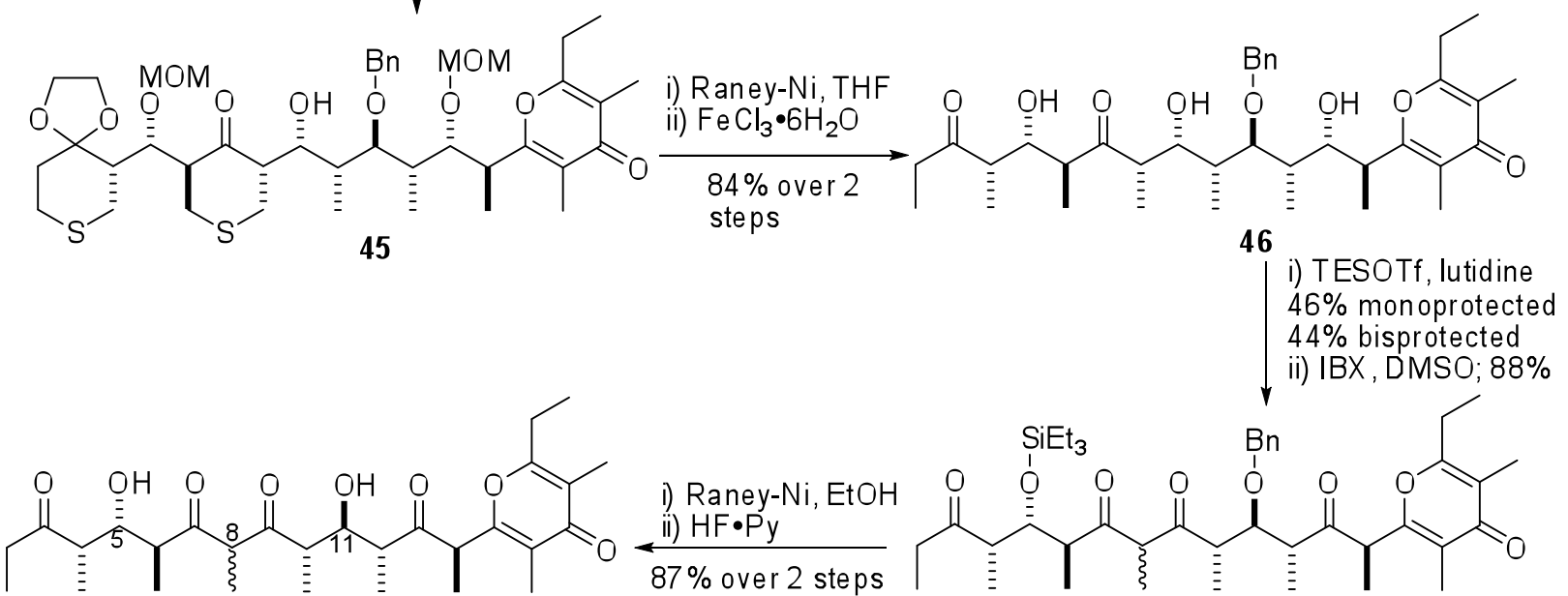
acyclic precursor (48)

47
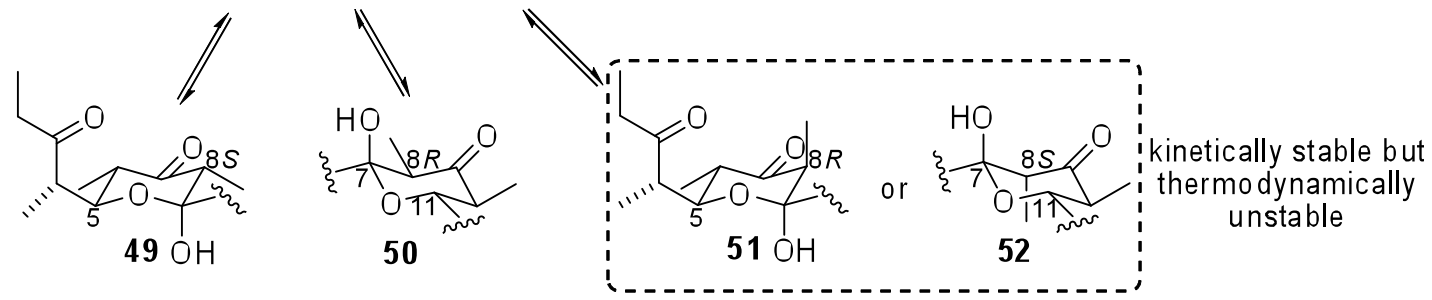
With the acyclic precursor $\mathbf{4 8}$ in hand, its isomerisation was studied under different conditions (Scheme 1.6). This was the first time that the thermodynamic equilibrium of siphonariid polypropionates could be studied starting from 48. As noted above, 48 was a

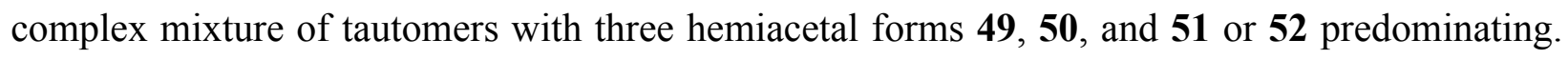
This mixture was essentially unchanged after 28 days in $\mathrm{CDCl}_{3}$. However, treatment of $\mathbf{4 8}$ with imidazole in $\mathrm{CDCl}_{3}$ for $24 \mathrm{~h}$ produced $\mathbf{2}$ in $70 \%$ isolated yield. Reaction of $\mathbf{4 8}$ with DBU in $\mathrm{C}_{6} \mathrm{D}_{6}$ solution for $1 \mathrm{~h}$ produced a mixture of baconipyrone C (6) (50\%) and its C-14 epimer (30\%). Treatment of $\mathbf{4 8}$ with neutral alumina in refluxing ethanol produced a 10:3:7:3 mixture of $\mathbf{5 3}$ (40\% isolated), 4 (10\% isolated), $\mathbf{6}$, and $\mathbf{2}$, respectively. The major product $\mathbf{5 3}$, a structural isomer of baconipyrone $\mathrm{C}(\mathbf{6})$ arising from retro-Claisen fragmentation of hemiacetal $\mathbf{5 0}$ or $\mathbf{5 2}$, had not been previous reported. Finally, treatment of $\mathbf{2}$ with neutral alumina in refluxing ethanol produced a 2.3:3:1:1 mixture of $\mathbf{2}, \mathbf{6}, \mathbf{4}$, and $\mathbf{4 8}$, respectively, but not $\mathbf{5 3}$. It is noteworthy that both 4 and $\mathbf{6}$ were stable to these reaction conditions. Surprisingly, caloundrin B (3) was never detected in the isomerization experiments and its presence remained as a missing piece of the puzzle about the origin of all of those polypropionates. ${ }^{9}$

Preparation of compound 54, where the $\mathrm{OH}$ group at $\mathrm{C}-11$ was protected thereby limiting the options for cyclization, allowed the assessment of another isomerisation experiment. After exposure of compound $\mathbf{5 4}$ to neutral alumina in refluxing ethanol and then debenzylation, baconipyrones 4 and $\mathbf{6}$ were produced in 18\% and 70\% yields, respectively. 
Scheme 1.6 Isomerization of acyclic precursor 48 .

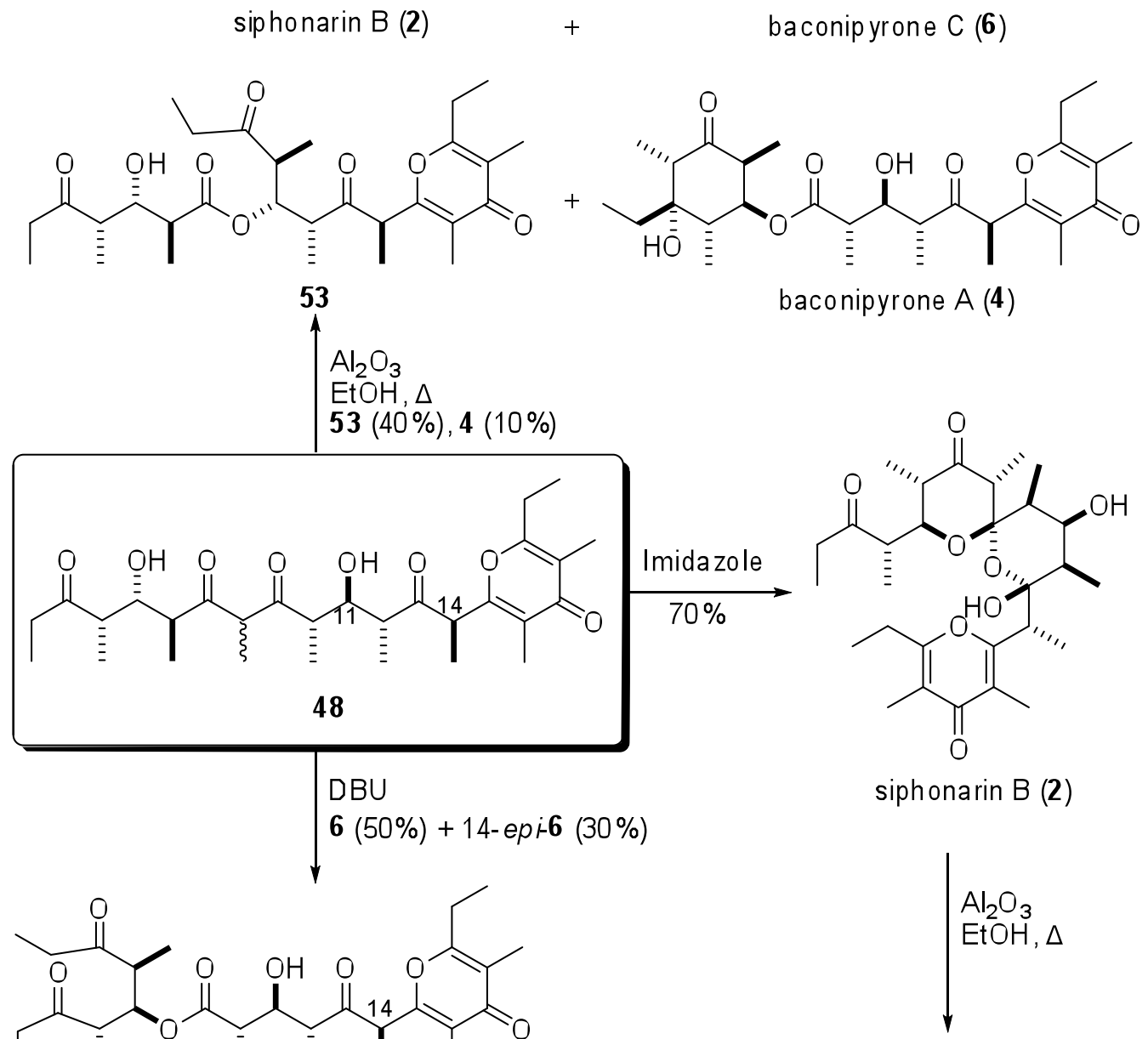

siphonarin $B(2)$ baconipyrone $A(4)$

baconip yrone $C(\mathbf{6})$

baconip yrone $C(\mathbf{6})$

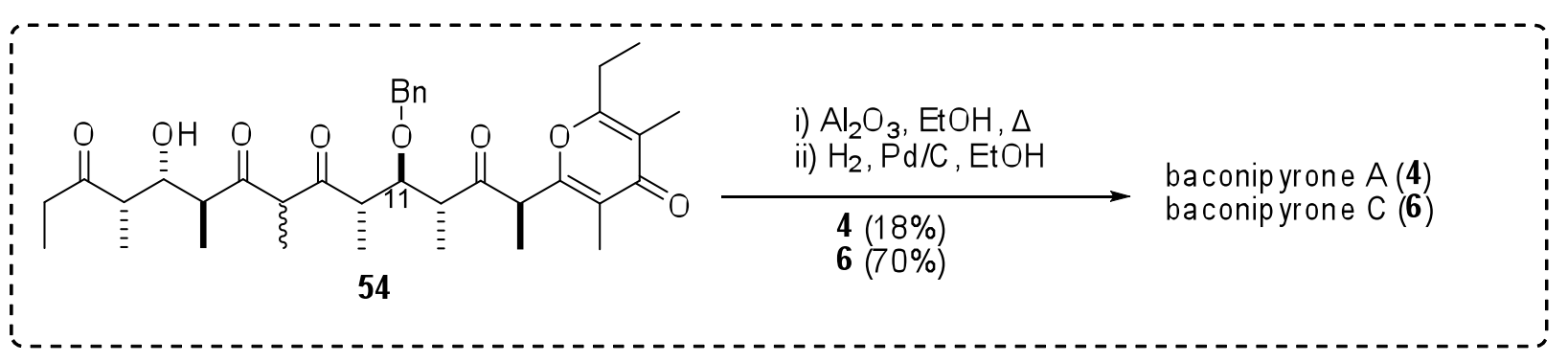




\subsubsection{Revised hypothesis on the origin of siphonariid polypropionates}

Very important conclusions emerged from the Ward and Beye syntheses of siphonarin B (2), baconipyrone A (4) and C (6) from the presumed acyclic precursor 48 . $^{9}$ With the information provided by Ward ${ }^{9}$ and Garson ${ }^{11}$ it was conclusive that the baconipyrones were likely artifacts from isolation coming from the hemiacetal forms of $\mathbf{4 8}$ or by ring-opening of siphonarin B (2). These observations supported the previously proposed hypothesis but also established new questions about the origin of those compounds. In this context, it was proposed that if baconipyrones 4 and 6 came from the acyclic precursor 48; then, the hemiacetal forms 49 and 50, ${ }^{\ddagger}$ compound $\mathbf{5 3}$ and 14-epi-6 should be observed during the isolation process. Because none of these compounds had been isolated from Siphonaria zelandica, it was most likely that the baconipyrones 4 and $\mathbf{6}$ originate from $\mathbf{2}$. Additionally, $\mathbf{2}$ could be the biosynthetic product. However, this hypothesis would not explain the origin of $\mathbf{3}$.

Therefore, it was hypothesized that $\mathbf{3}$ could be less stable than $\mathbf{2}$ or that access to $\mathbf{3}$ involved a high energy barrier. Indeed, 3 could be the biosynthetic product from which the formation of $\mathbf{2}$, 4, and 6 could be explained. However, this revised hypothesis could only be tested if the synthesis of $\mathbf{3}$ could be achieved (Figure 1.5).

\footnotetext{
$\$$ The hemiacetal forms $\mathbf{4 9}$ and $\mathbf{5 0}$ coming from the acyclic precursor $\mathbf{4 8}$ were stable to storage in $\mathrm{CDCl}_{3}$ for $28 \mathrm{~d}$ and exposure to $\mathrm{SiO}_{2}$.
} 

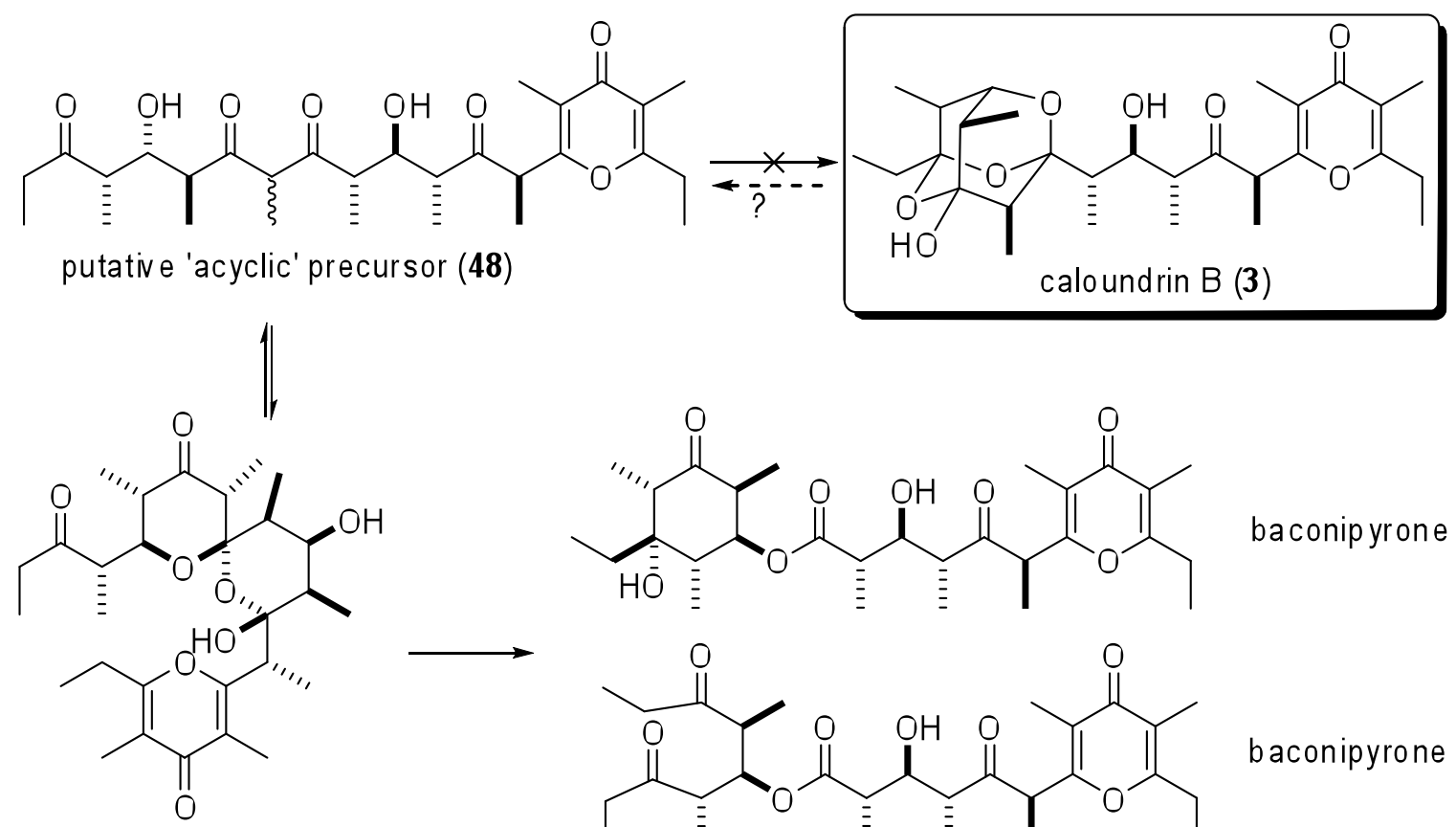

siphonarin B (2)<smiles>CCc1oc(C(C)C(=O)[C@H](C)[C@H](O)[C@H](C)C(=O)OC2C(C)C(=O)[C@@H](C)[C@](O)(CC)[C@@H]2C)c(C)c(=O)c1C</smiles>

Figure 1.5 Revised hypothesis on the origin of siphonariid polypropionates

\subsection{Syntheses of trioxaadamantane ring systems}

\subsubsection{Hoffmann's synthesis of the trioxaadamantane ring system of muamvatin}

Isolated in 1986 from Siphonaria normalis, muamvatin (19; Figure 1.3) was the first natural product identified containing a trioxaadamantane ring system. ${ }^{32}$ In 1994 , initial studies to form the racemic trioxaadamantane model $\mathbf{5 8}$ were reported by Hoffmann et al. ${ }^{33}$ The synthesis started with methacrolein to produce aldehyde 55 after 7 steps. Aldol reaction of 55 with the (Z)enol borinate from 3-pentanone afforded $\mathbf{5 6}$ as a single diastereomer in 85\% yield. Finally, Swern oxidation on $\mathbf{5 6}$ gave the protected 3-hydroxy-1,5,7-trione 57, that after exposure to $\mathrm{HF} \bullet$ pyridine and $\mathrm{H}_{2} \mathrm{O}$ in THF furnished the trioxaadamantane $\mathbf{5 8}$ in $49 \%$ yield after 2 steps. 
Scheme 1.7 Model studies to form the trioxaadamantane moiety of muamvatin (19).

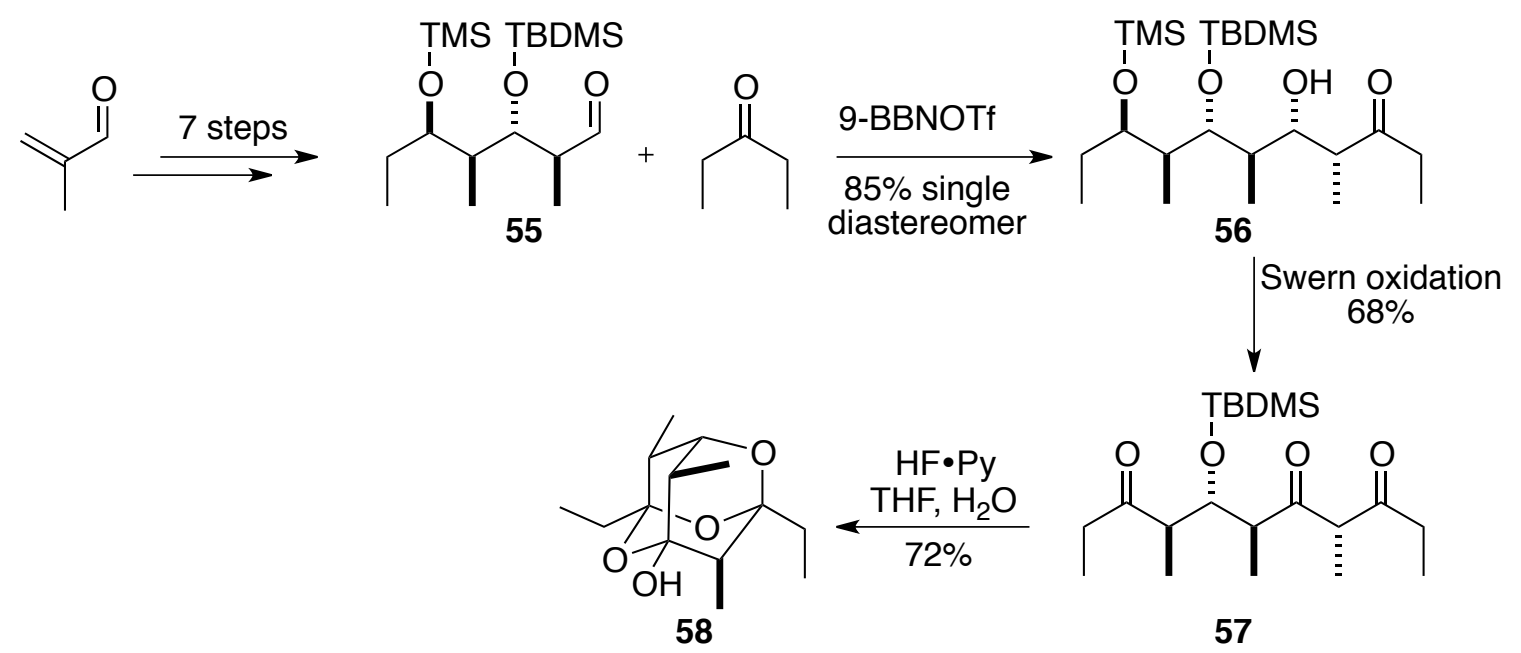

In order to establish the absolute and relative configuration of muamvatin (19) at C-10, Hoffmann studied the synthesis of aldehydes $\mathbf{6 5}$ and $\mathbf{6 9}$ (Scheme 1.8). ${ }^{34,35}$ One of the aldehydes was previously obtained from degradation of muamvatin (19) by Ireland. ${ }^{32}$

Hoffmann's approach started from methacrolein and $\mathbf{5 9}$ to produce aldehyde $\mathbf{6 0}$ in 7 steps. Thereafter, aldol reactions of $\mathbf{6 0}$ with the (Z)-enol borinates of $\mathbf{6 1}$ or ent-61 produced the aldol adducts 62 and 66, respectively. After Swern oxidation and prolonged exposure to $\mathrm{HF} \bullet$ pyridine and $\mathrm{H}_{2} \mathrm{O}$ in THF, 62 and $\mathbf{6 6}$ were converted to $\mathbf{6 4}(60 \%)$ and $\mathbf{6 8}(45 \%)$, respectively. The aldehydes 65 and 69 were obtained from 64 and 68 , respectively, by $O$ debenzylation and subsequent oxidation. Aldehyde 65, which possesses the $(S)$-configuration at $\mathrm{C}-10$, has the same relative configuration as the trioxaadamantane fragment present in muamvatin (19). 
Scheme 1.8 Formation of the trioxaadamantane moiety of muamvatin (19).
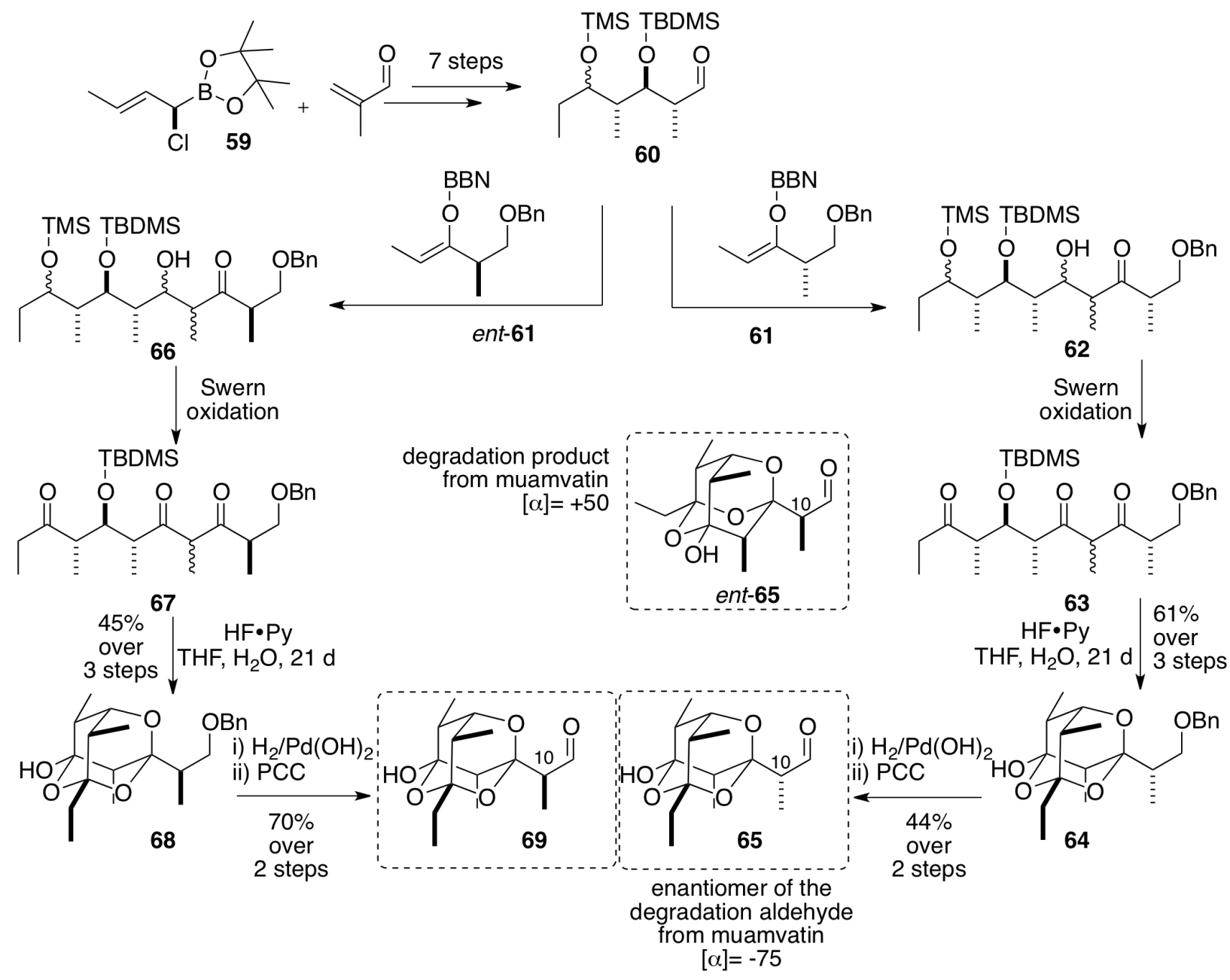

\subsubsection{Paterson's synthesis of muamvatin}

In 1993, Paterson achieved the first total synthesis of muamvatin (19), confirming the relative and absolute configuration of the compound. ${ }^{36}$ The synthesis of the trioxaadamantane moiety ent-64 involved a Sn(II) mediated aldol reaction between ketone 24 and propionaldehyde, followed by a selective anti reduction of the aldol adduct 70, silyl protection, debenzylation, and oxidation to produce aldehyde 71. Aldol reaction of $\mathbf{7 1}$ with the boron enolate of $\mathbf{2 4}$ produced $\mathbf{7 2}$, which after silyl deprotection cyclised to the hemiacetal $\mathbf{7 3}$ as a single isomer in $72 \%$ yield. Further oxidation of $\mathbf{7 3}$ produced the hemiacetal $\mathbf{7 4}$, a tautomer of the trioxaadamantane ring system. However, exposure of $\mathbf{7 4}$ to acidic conditions, only produced dehydration. In contrast, 
exposure of $\mathbf{7 4}$ to silica gel for $18 \mathrm{~h}$ produced the desired trioxaadamantane ring system ent-64 in $92 \%$ yield.

Scheme 1.9 Paterson's synthesis of muamvatin (19).

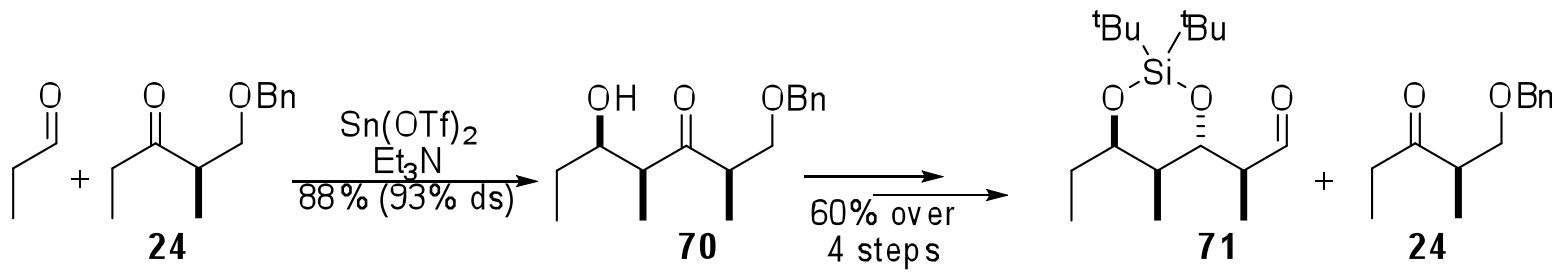<smiles>CCC(=O)C(C)[C@H]1O[C@](O)(C(C)CO)[C@@H](C)C(=O)[C@H]1C</smiles>

74

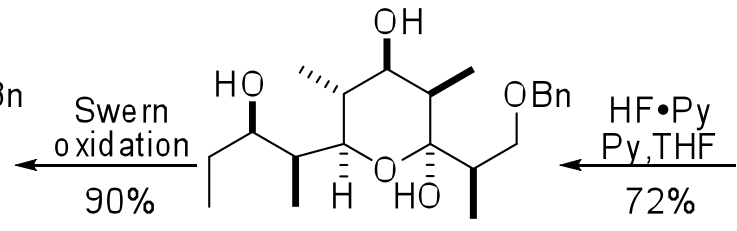

73

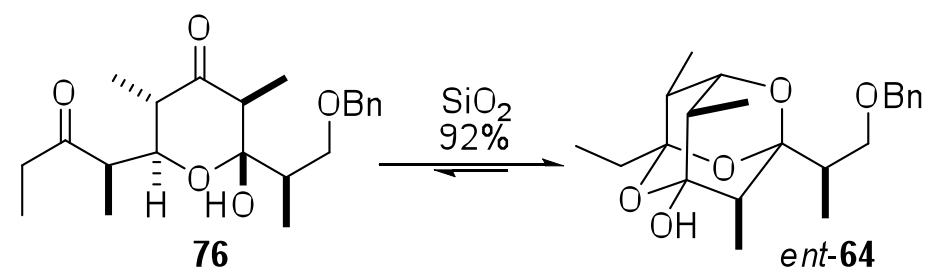

76

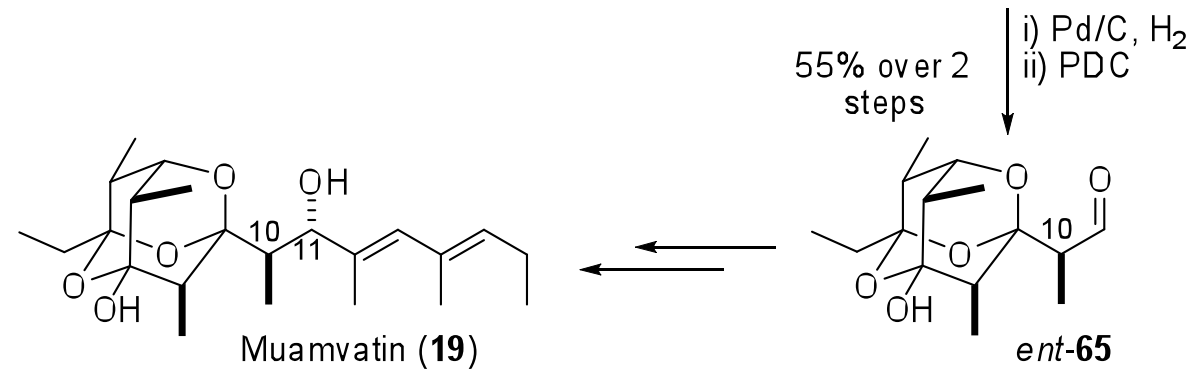
tBu tBu<smiles>CCC1O[Si](C)(C)O[C@@H](C(C)C(O)[C@@H](C)C(=O)C(C)COc2ccccc2)C1C</smiles>

72<smiles>CCC(=O)C(C)[C@@H](O)C(C)C(=O)[C@H](C)C(=O)C(C)COc1ccccc1</smiles>

75

Hydrogenolysis of the benzyl ether in ent-64 followed by oxidation of the resulting alcohol generated aldehyde ent-65 which was in agreement with the trioxaadamantane aldehyde isolated from degradation of muamvatin 19. ${ }^{32}$ Therefore, the relative configuration at C-10 was established. Further manipulations to introduce the diene fragment and establish the configuration at C-11, produced muamvatin (19) in 14 steps. Paterson proposed that due to the 
straightforward formation of the trioxaadamantane ent-64 under $\mathrm{SiO}_{2}$ conditions, muamvatin (19) could be an artifact of isolation.

\subsubsection{Perkins' approach to Dolabriferol}

It is interesting that in one of the approaches towards the synthesis of dolabriferol (83), Perkins observed the formation of the trioxaadamantane ring system $\mathbf{7 9}$ (Scheme 1.10). ${ }^{37}$ When compound 78 (Scheme 1.10) was subjected to tris(dimethylamino)sulphonium difluorotrimethylsilicate (TAS-F) to remove the silyl groups, ${ }^{38}$ followed by addition of DBU, surprisingly compound $\mathbf{7 9}$ was produced in $78 \%$. Similarly, treatment of $\mathbf{7 8}$ with HF•pyridine and pyridine in THF efficiently provided the trioxaadamantane 79 in $88 \%$ yield. These last conditions used to form 79 were very similar to those used by Hoffmann in his model studies for the preparation of trioxaadamantanes 64 and $\mathbf{6 8}$ (Scheme 1.8). To date, this is the only example of the formation of a trioxaadamantane bearing a side chain larger than three carbons from a 3hydroxy-1,5,7-trione or hemiacetal precursor.

Exposure of $\mathbf{7 9}$ to DBU for a longer reaction time produced $\mathbf{8 0}$ from a ring opening and retro-Claisen reaction sequence. Finally, the ester was transformed to the enone $\mathbf{8 1}$ on prolonged exposure to DBU. On the other hand, spiroketal 82 was obtained when $\mathbf{8 0}$ was treated with aqueous HF, a process that presumably involved a Claisen reaction. This is the only example where a retro-Claisen fragmentation (e.g., 79 to 80 ) has been shown to be reversible. 
Scheme 1.10 Formation of a trioxaadamantane moiety during Perkin's approach towards the synthesis of dolabriferol (83).

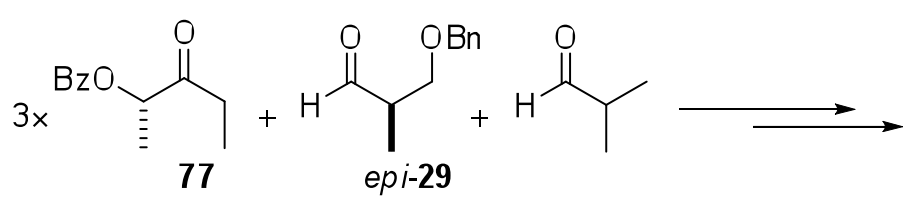

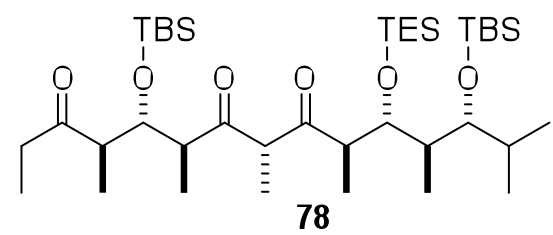

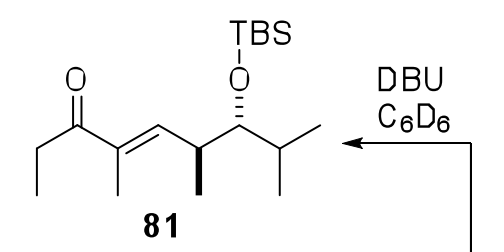

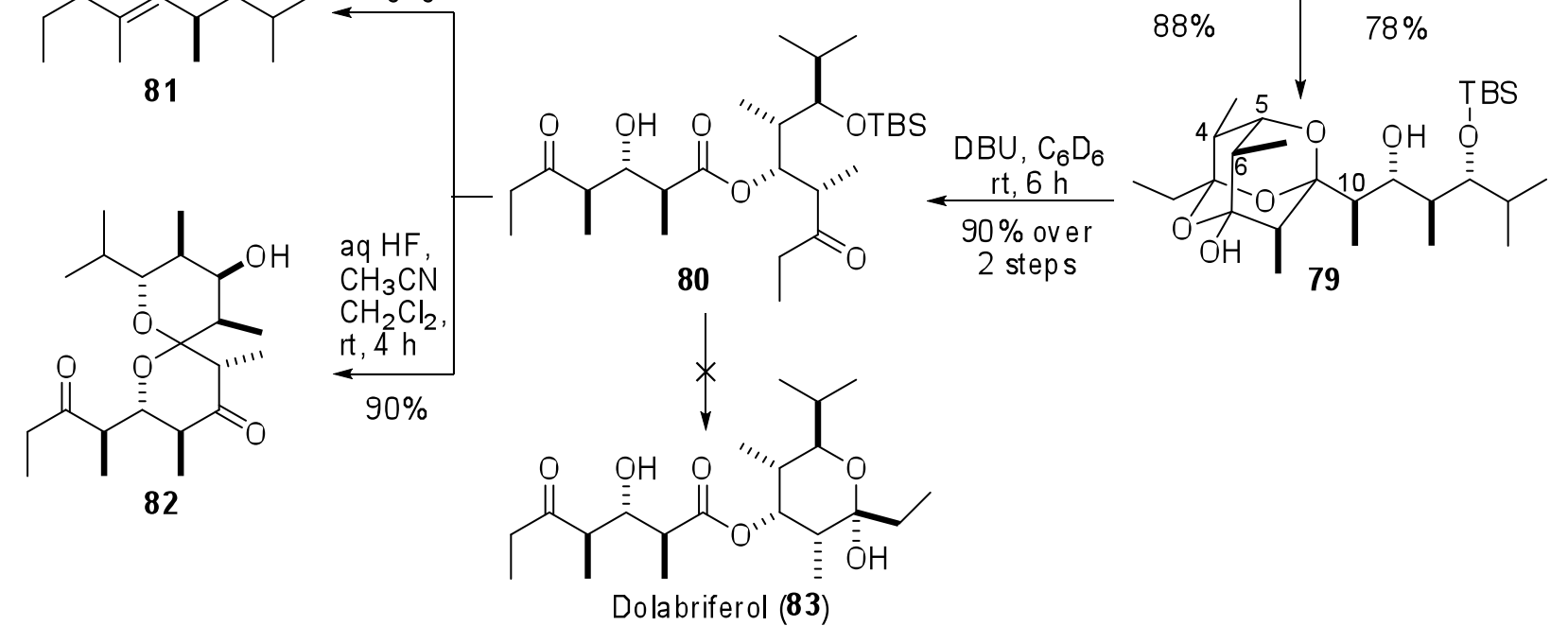

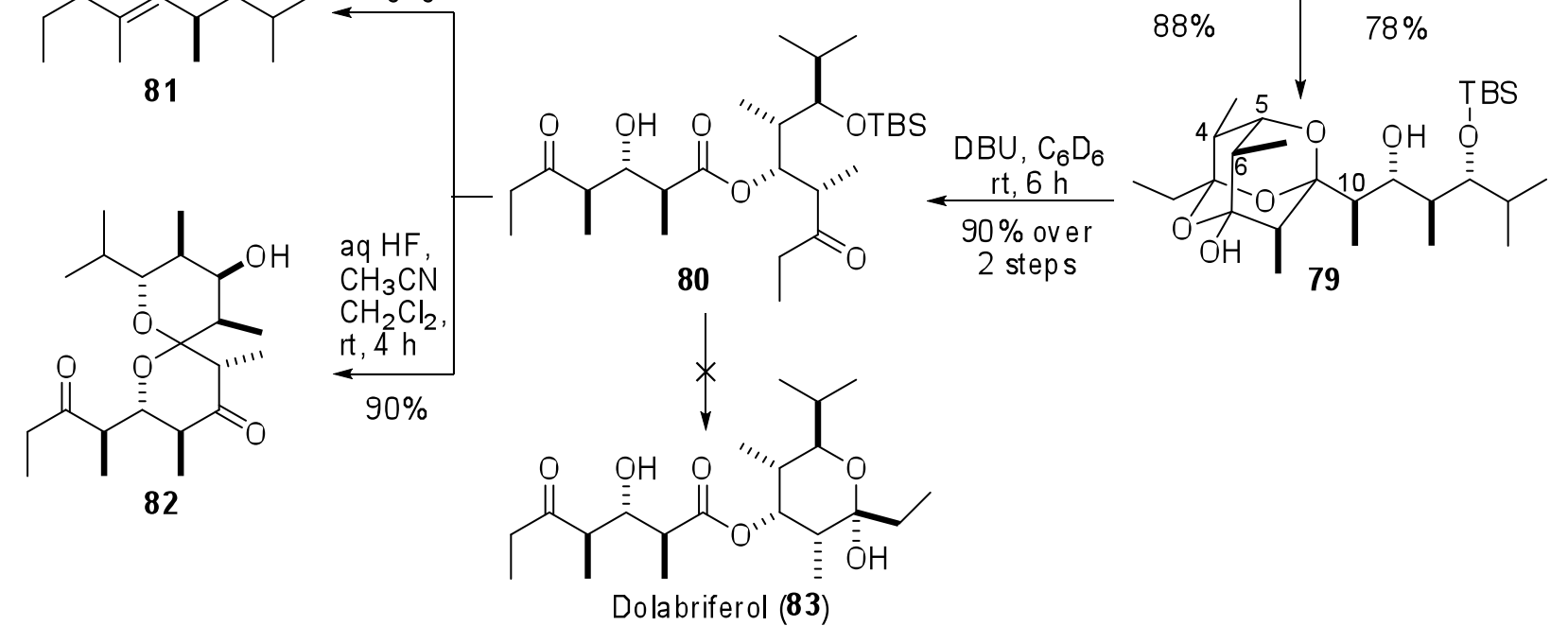

\subsubsection{Ward's synthesis of the trioxaadamantane ring systems of muamvatin and caloundrin B}

In 2009, Ward et al. performed model studies to form the trioxaadamantane ring systems present in muamvatin (19) and caloundrin B (3). ${ }^{39}$ Their strategy, utilized thiopyran fragments to form sulphur-bridged trioxaadamantanes $\mathbf{8 7}$ and $\mathbf{9 3}$, that subsequently could be desulfurized and finally isomerized to the more stable trioxaadamantane species $\mathbf{8 9}$ and $\mathbf{5 8}$, respectively. ${ }^{39}$ Interestingly, the isomerizations of trioxaadamantanes, $\mathbf{8 8}$ and $\mathbf{9 4}$, were very different. Whereas isomerization of $\mathbf{9 4}$ in the presence of imidazole cleanly formed the more stable trioxaadamantane $\mathbf{5 8}$ in excellent yield, isomerization of $\mathbf{8 8}$ produced the trioxaadamantane $\mathbf{8 9}$ 
along with the hemiacetal form 90 and the ester 91; the latter produced from a retro-Claisen reaction of the hemiacetal forms (i.e. 90). This methodology, allowed the selective preparation of compounds 89, 90, and 91, truncated forms of caloundrin B (3), siphonarin B (2), and baconipyrone $\mathrm{C}(\mathbf{6})$, by using the appropriate isomerization conditions. This was the first example where the formation of the trioxaadamantane moiety from caloundrin B (2) was demonstrated.

Scheme 1.11 Synthesis of model trioxaadamantanes (58 and 89) from muamvatin (19) and caloundrin B (2).<smiles>CCC(O)[C@H]1CSC[C@H]([C@@H](OC)[C@H]2CSCCC23OCCO3)C1=O</smiles>

92

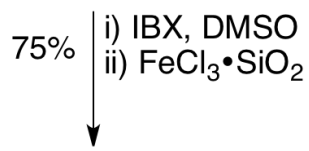

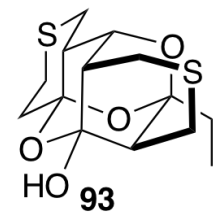

93

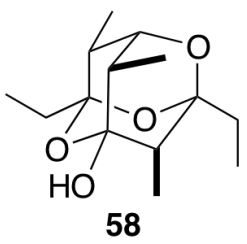

Imidazole, $\mathrm{CDCl}_{3}$

$\leftarrow 40{ }^{\circ} \mathrm{C}, 4 \mathrm{~d}$<smiles>O=C[C@H]1CSCCC12OCCO2</smiles>

84<smiles>O=C1CCSCC1</smiles>

85

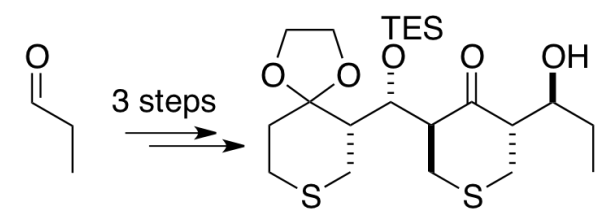

86

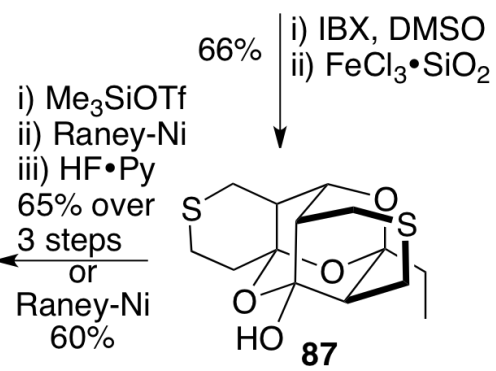

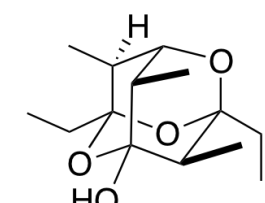

94

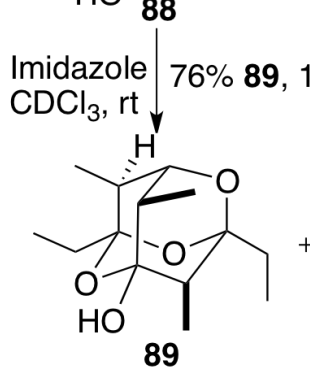

89
87<smiles>CCC(=O)C(C)[C@]1(C)O[C@](O)(CC)C(C)C(=O)C1C</smiles> 


\subsection{Conclusions}

To date, the achievements in the synthesis of $\mathbf{2 , 4}$, and $\mathbf{6}$ and their putative acyclic precursor 48 have confirmed their relative and absolute configurations and afforded the study of their interrelationships. Yet the synthesis of $\mathbf{3}$ remains a challenge to be solved. Achievement of the synthesis of $\mathbf{3}$ would allow confirmation of the proposed structure and would allow testing of the revised hypothesis about the origin of the siphonariid polypropionates.

Since caloundrin B (3) was not observed during the biomimetic synthesis of 2, 4, and 6 from the corresponding acyclic precursor (48), the synthesis of $\mathbf{3}$ should be approached using a different strategy. As an alternative, a convergent synthesis of $\mathbf{3}$ is proposed, where the $\gamma$-pyrone fragment would be coupled with a preformed trioxaadamantane fragment. Several different procedures to form the trioxaadamantane fragment of muamvatin (19) have been reported by Hoffman, ${ }^{33-35}$ Paterson, ${ }^{36}$ Perkins, ${ }^{37}$ and Ward ${ }^{39}$ However, the only report for the formation of the trioxaadamantane ring system of caloundrin B was disclosed by Ward et al. in $2009 .{ }^{39}$ With this precedent in hand, research was directed towards the synthesis of caloundrin B. 


\section{RESULTS AND DISCUSSION}

\section{CHAPTER 2}

\subsection{Research objectives}

One of the key objectives in this research project was to explore the relationship between the siphonariid polypropionates caloundrin B (3) and its structural isomers siphonarin B (2), baconipyrone A (4) and C (6), all isolated from extracts of Siphonaria zelandica. To enable this study, it was essential to have access to caloundrin B (3). However, there are no reports on the synthesis of caloundrin B (3) and the single report on the isolation of 3 (1.6 mg from 160 animals) revealed that it was unstable. Therefore, a carefully designed synthetic route would be required to obtain 3 by total synthesis (Figure 2.1).

Caloundrin B (3) was not observed in various attempts at isomerizations of the putative common acyclic precursor (48) $)^{9}$ or siphonarin B (2). ${ }^{9,}{ }^{15}$ Therefore, a convergent synthesis of $\mathbf{3}$ was proposed involving aldol coupling of the trioxaadamantane-containing ketone 95 with the $\gamma$ pyrone-containing aldehyde $( \pm)$-30. The proposed use of the racemic fragment $( \pm)$-30 for this strategy would require studies of methodology on the design of aldol reactions that proceed with kinetic resolution (vide infra). On the other hand, the stereoselective synthesis of the trioxaadamantane fragment using the thiopyran route to polypropionates ${ }^{29,} 40$ was envisaged. However, the development of a methodology to form a trioxaadamantane possessing an appropriate functional 'handle' would be required. 


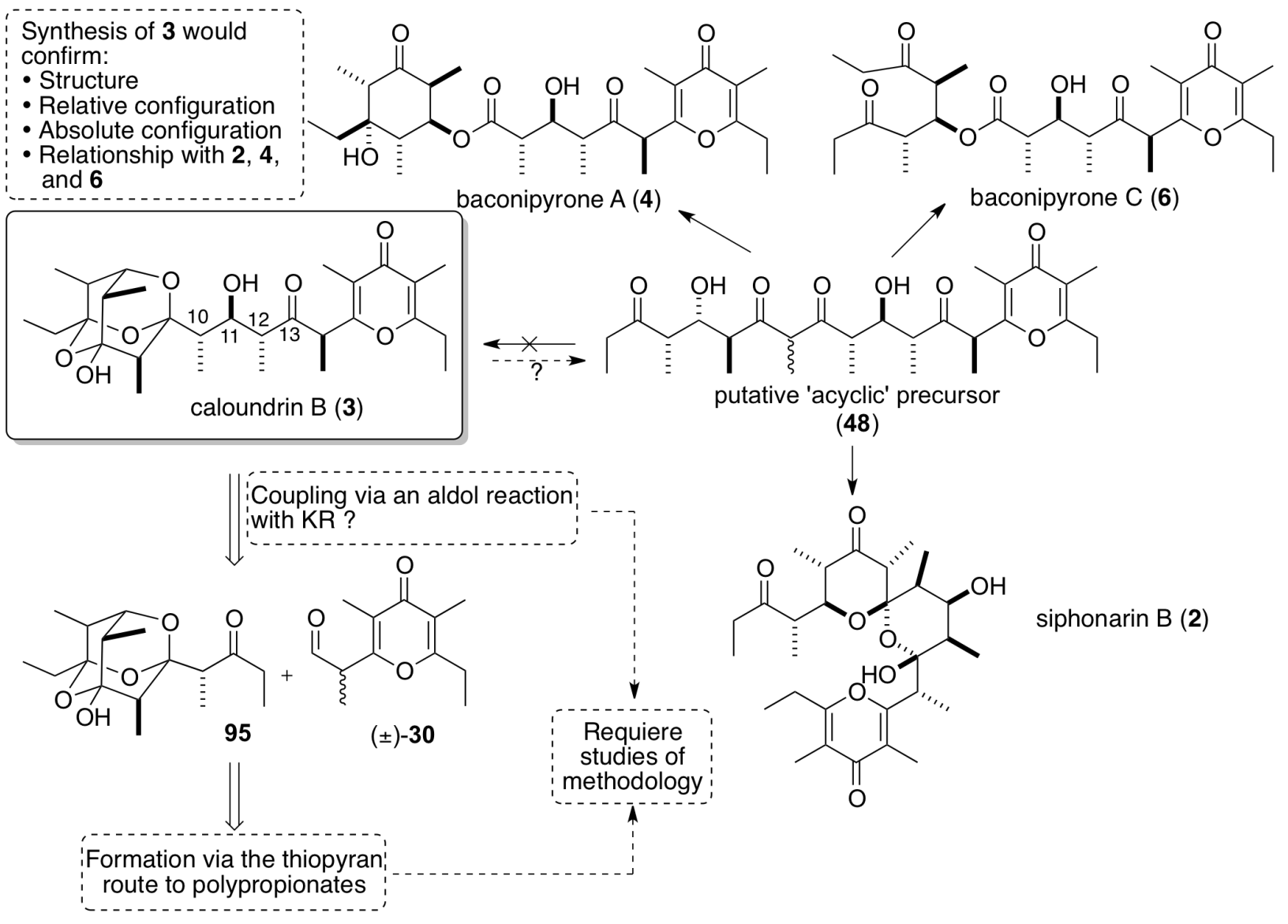

Figure 2.1 Major objectives of the research

\subsection{Retrosynthetic analysis of caloundrin B}

The failure to produce caloundrin B (3) by attempted isomerization of either $\mathbf{2}$ or $\mathbf{4 8}$ seemed to predicate a synthetic plan based on elaboration of a preformed trioxaadamantane fragment. ${ }^{9}$ The presence of the $\beta$-hydroxyketone in $\mathbf{3}$ suggested a convergent approach based on aldol coupling of two fragments of similar size. The perhaps more obvious disconnection of the C-11, C-12 bond was rejected because of anticipated difficulties in forming an enolate in the presence of a pyrone and in achieving the required 10,11-anti-11,12-anti-12,14-anti stereoselectivity. Instead, disconnection of the C-12, C-13 bond was envisaged to produce the two key fragments, 95 and $( \pm$ )-30 (Scheme 2.1). Both enantiomers of the aldehyde $\mathbf{3 0}$ are known $^{7,12,41}$ and the unknown $( \pm)$-30 should be available from the $\gamma$-pyrone $96,{ }^{42}$ easily prepared 
by oligomerization of propionic acid as described by Mullock and Suschitzky. ${ }^{43}$ The more challenging fragment 95 could be prepared by strategically cleaving the bond between C-8 and C-9 in its open tautomeric form $\mathbf{9 7}$, which would generate the synthon 98 and fragment 99 . The later fragment (99) is easily accessible in enantioenriched form employing the methodology developed in the Ward group for the synthesis of tetrapropionate units. ${ }^{29,}{ }^{40,44}$ Finally, the enantiopure fragment $\mathbf{9 8}$ could be generated by several different methods; for example, from a thiopyran fragment (i.e. 100), by hydroboration of an olefin and then insertion of an ethyl group, or employing the Roche ester (ent-27) followed by functionalization and chain extension.

Scheme 2.1 Synthetic strategies for the synthesis of caloundrin B (3).

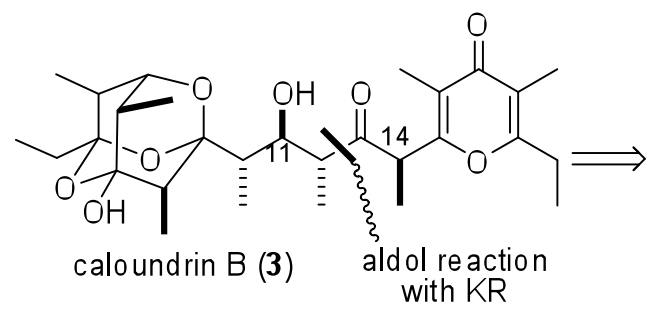

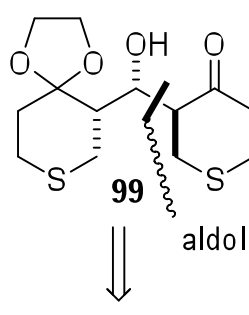<smiles>O=CC1CSCCC12OCCO2</smiles>

84

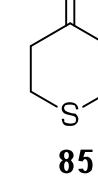<smiles>CCC(=O)[C@H](C)C=O</smiles>

85 $\downarrow$
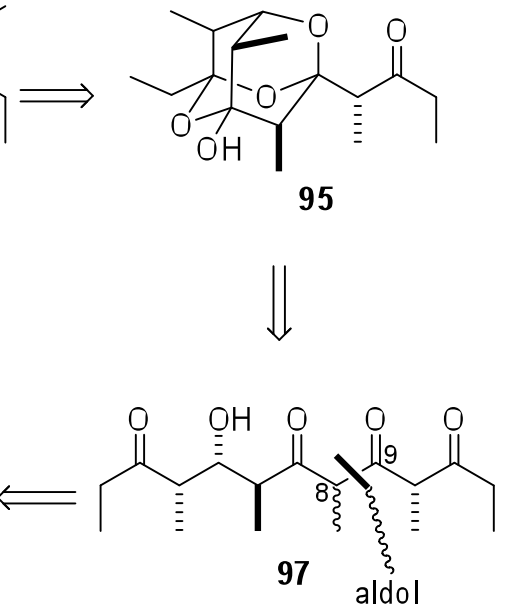

98

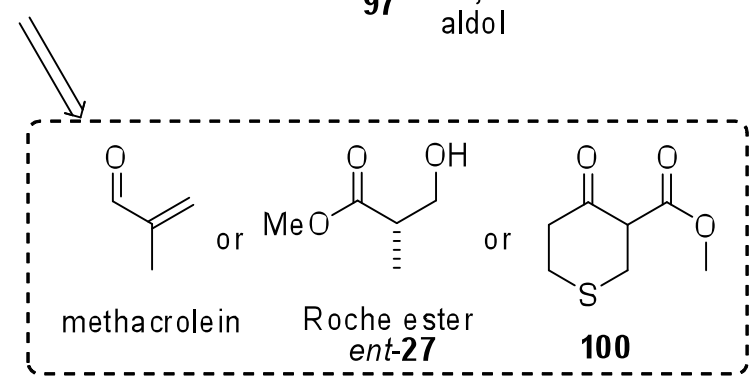<smiles>C=C</smiles><smiles>C=COC(=O)C1CSCCC1=O</smiles>

100<smiles>[R4]C(=O)OC</smiles>

101
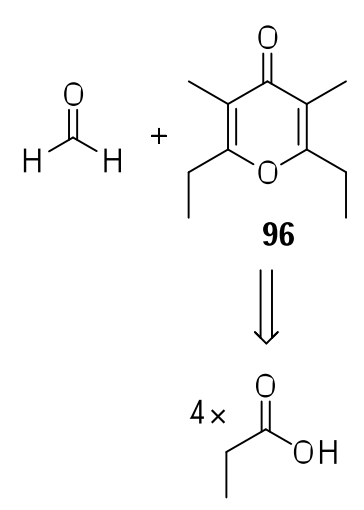

\section{$( \pm)-30$}<smiles>C=C</smiles>

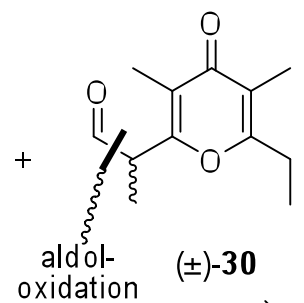




\subsection{Formation of the trioxaadamantane ring system of caloundrin B}

To date, the only study on the formation of the trioxaadamantane ring system present in caloundrin B (3) was reported by Ward et al. ${ }^{39}$ In that work, the pentacyclic sulphur-bridged trioxaadamantane $106(\mathrm{R}=\mathrm{Et})$ was produced directly during $\mathrm{FeCl}_{3}$ mediated deprotection of the TES ether and ethylene acetal present in $104(\mathrm{R}=\mathrm{Et})$. The latter was easily prepared by an aldol/oxidation sequence on readily available tetrapropionate precursor 102. Desulfurization of $106(\mathrm{R}=\mathrm{Et})$ produced the isolable $107(\mathrm{R}=\mathrm{Et})$ as a thermodynamically unstable protected form of a 3-hydroxy-1,5,7-trione. Ring-chain tautomerism of $\mathbf{1 0 7}(\mathrm{R}=\mathrm{Et})$ was studied under various reaction conditions and under thermodynamic control, the isomeric trioxaadamantane $108(\mathrm{R}=$ Et) was virtually the exclusive product. The transformation of $\mathbf{1 0 7}$ to 108 required isomerization at C-8 and this was shown to occur via keto-enol tautomerism of the open form $112(\mathrm{R}=\mathrm{Et})$. It should be noted that because $108(\mathrm{R}=\mathrm{Et})$ was produced under thermodynamic control, it could be anticipated that the synthesis of any of the tautomers [e.g., $107(\mathrm{R}=\mathrm{Et}), \mathbf{1 1 2}(\mathrm{R}=\mathrm{Et}), \mathbf{1 1 3}(\mathrm{R}$ $=\mathrm{Et})]$ would also lead to $\mathbf{1 0 8}(\mathrm{R}=\mathrm{Et})$ under thermodynamic control.

In the present research, two different approaches were proposed to study the formation of trioxaadamantane fragments with different substituents at C-9 that might be suitable for elaboration into the desired 95. The first route (route A in Scheme 2.2) was analogous to the approach previously developed by Ward et al. to form $108(\mathrm{R}=\mathrm{Et})$ as a model trioxaadamantane ring system for caloundrin $\mathrm{B} .{ }^{39}$ Alternatively, in route $\mathrm{B}$ it was proposed to start with the desulfurized aldol adduct 109. Aldol reaction of 109 with a suitable aldehyde would give 110. In contrast to 103, an oxidation/deprotection sequence on $\mathbf{1 1 0}$ would be unproductive as 3-hydroxy1,5,7-triones are known to be unstable to the acidic conditions necessary to remove an ethylene

acetal. $^{8}, 33,36$ Acid mediated deprotection of $\mathbf{1 1 0}$ should be feasible but would require a chemoselective oxidation of the resulting diol 111 to obtain a tautomer of the desired $\mathbf{1 0 8}$. 
Scheme 2.2 Strategies proposed to form trioxaadamantane systems $\mathbf{1 0 8}$.

\section{Route A}

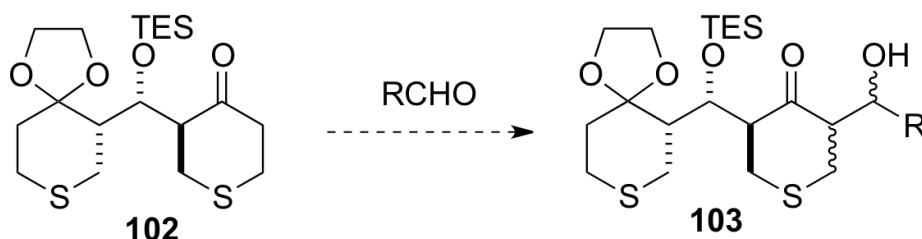<smiles>[R]C(=O)C1CSCC([C@H](OC(C)C)[C@H]2CSCCC23OCCO3)C1=O</smiles>

104 deprotection

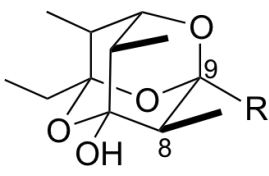

107

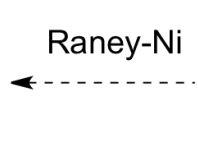<smiles>[R]C(=O)C(C)C(=O)C([Y20])[C@@H](O[In]I)[C@@H](C)C(=O)CC</smiles>

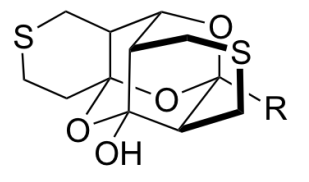

106

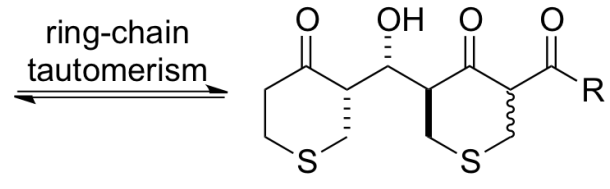

105

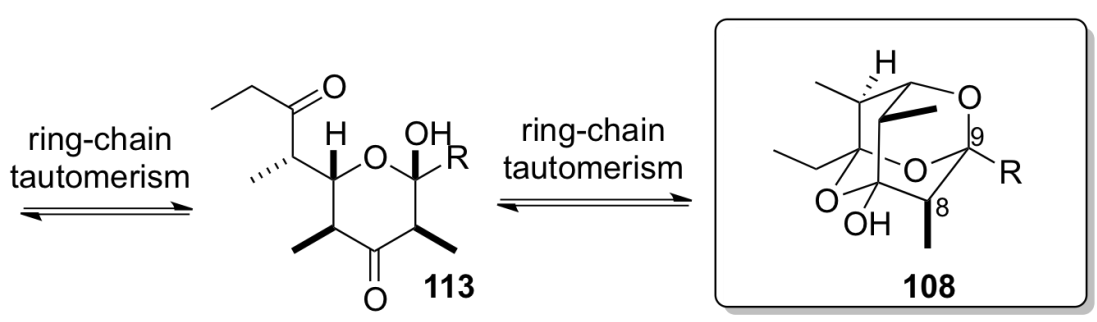
'chemoselective' [O]

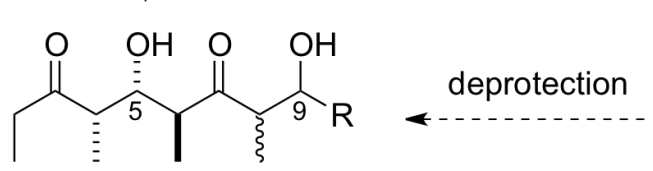
111

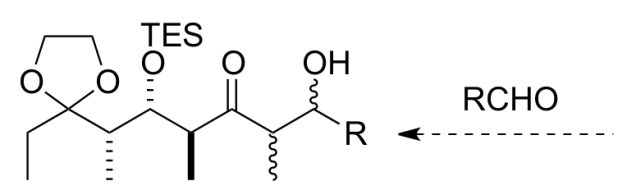

110

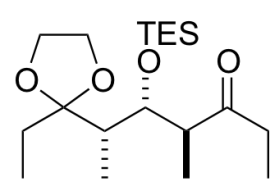

109<smiles>C=C(C)CCCCC(C)COCC(C)C</smiles>

Route B

The goal of this study was to identify suitable precursors for the formation of a trioxaadamantane bearing a substituent at C-9 that would allow further manipulation to ketone 95. The 'R groups' illustrated in Scheme 2.2 were selected for several reasons. The trioxaadamantane needs to be formed under thermodynamic control and it was anticipated that 
the steric and electronic properties of the C-9 substituent would influence the equilibrium. Examination of the isopropyl substituent (from ${ }^{i} \mathrm{PrCHO}$ ) would confirm whether use of a substituent more hindered than ethyl would still favour trioxaadamantane formation. Successful formation of trioxaadamantane $\mathbf{1 1 4}$ with a 2-propenyl substituent (from acrolein) would allow functionalization, for example via hydroboration to give 115 (Scheme 2.3). Alternatively, producing a trioxaadamantane system such as $\mathbf{1 1 7}$ would require minimal functional group manipulations to produce the desired ketone 95. Finally, the use of Roche ester-derived aldehyde 29 could provide the minimally functionalized trioxaadamantane system 116. The protected hydoxypropyl substituent in aldehyde $\mathbf{2 9}$ is similar in size to the isopropyl group and the configuration at $\mathrm{C}-10$ in the resulting trioxaadamantane $\mathbf{1 1 6}$ would be fixed. Subsequently, that substituent could be elongated by addition of an ethyl group to produce the desired $\mathbf{9 5}$.

With the above objectives in mind, studies on the formation of the proposed trioxaadamantane ring systems were pursued and are described in this section. 
Scheme 2.3 Proposed approaches for the generation of trioxaadamantane systems that would allow further manipulation.<smiles>CCC(=O)[C@H](C)[C@@H](O)C(C)C(=O)[C@H](C)C(C)=O</smiles>

112

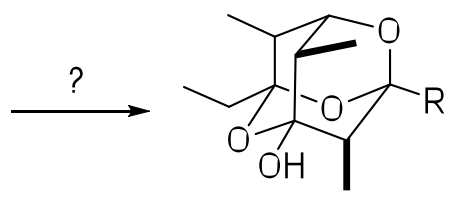

108

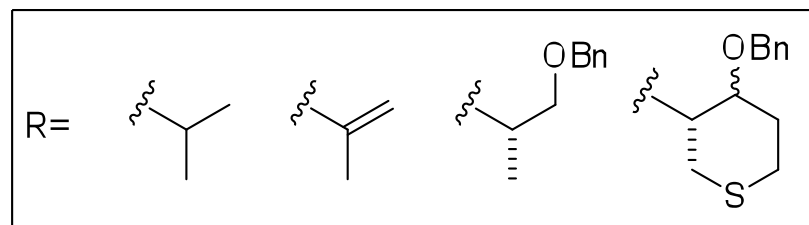

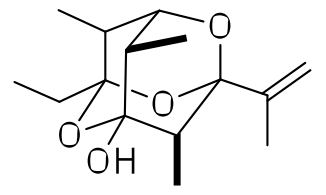

114

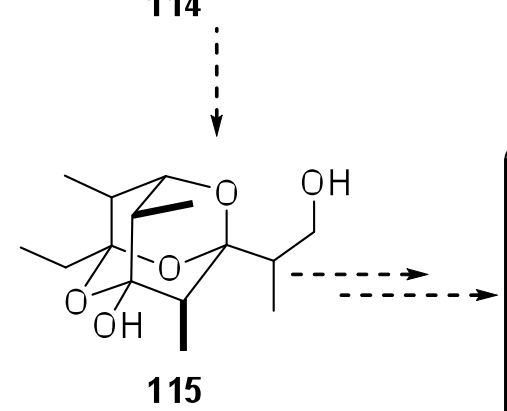

115

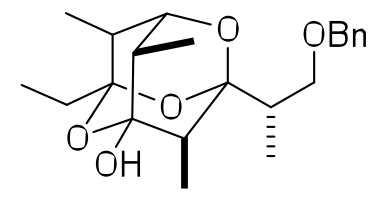

116

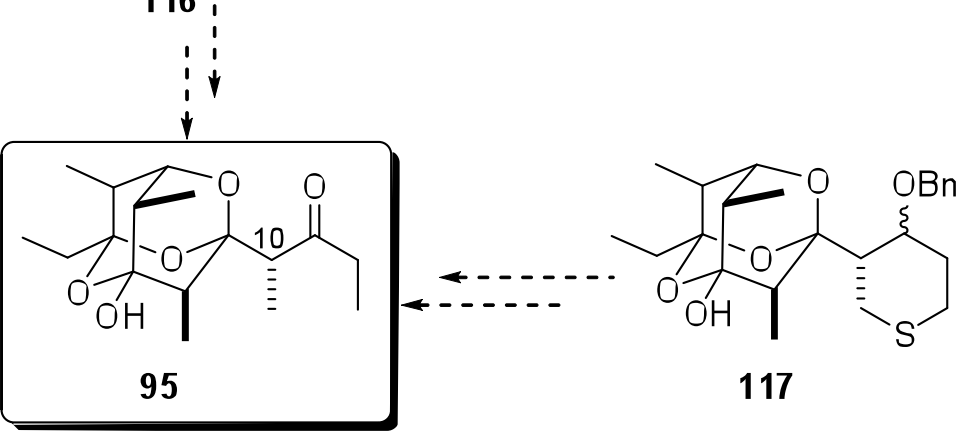

\subsubsection{Sulfur-bridged trioxaadamantanes from 5-alkanoyl-3-[hydroxy(4-oxotetrahydro- $2 H$-thiopyran-3-yl)methyl]dihydro-2H-thiopyran-4(3H)-one precursors}

\subsubsection{The isopropyl analogue (from the 5-(2-methylpropanoyl) precursor)}

Previously in the Ward group, it was demonstrated that the formation of a trioxaadamantane system bearing an ethyl substituent was possible using route A in Scheme 2.2. Thus, the first question in this project was if the size and complexity of the substituent were increased, would the trioxaadamantane still be thermodynamically favoured? In order to gain some insight on the impact of the size of the C-9 substituent, formation of the isopropyl analogue 
following route A (Scheme 2.2) was attempted. The aldol reaction of the boron enolate of racemic $1 \mathbf{1 0 2}^{\S}$ with isobutyraldehyde produced 118 as a single diastereomer in $82 \%$ yield (Scheme 2.4). Based on previous studies in the Ward group, ${ }^{45,46}$ aldol reactions of the TES protected boron enolate of $( \pm)-\mathbf{1 0 2}$ are known to produce aldol adducts with a 3,5-trans-5,1"-anti relative configuration. The aldol product $\mathbf{1 1 8}$ was subjected to oxidation with IBX in DMSO for $10 \mathrm{~h}$; subsequently, the crude product from oxidation was treated with $\mathrm{FeCl}_{3} \cdot 6 \mathrm{H}_{2} \mathrm{O}$ in refluxing acetone for $12 \mathrm{~h}$ affording $63 \%$ of the desired trioxadithiopentacycle 119. Raney-Ni desulfurization of $\mathbf{1 1 9}$ afforded trioxaadamantane $\mathbf{1 2 0}$ in 61\% yield. Exposure of $\mathbf{1 2 0}$ to imidazole at $40{ }^{\circ} \mathrm{C}$ for 8 days gave the thermodynamically more stable isomer $\mathbf{1 2 1}$ in $40 \%$ isolated yield.

Scheme 2.4 Formation of trioxaadamantane system bearing an isopropyl substituent following route $\mathrm{A}$.<smiles>CCO[C@@H](C1CSCCC1=O)[C@@H]1CCSCC12OCCO2</smiles>

$( \pm)-102$
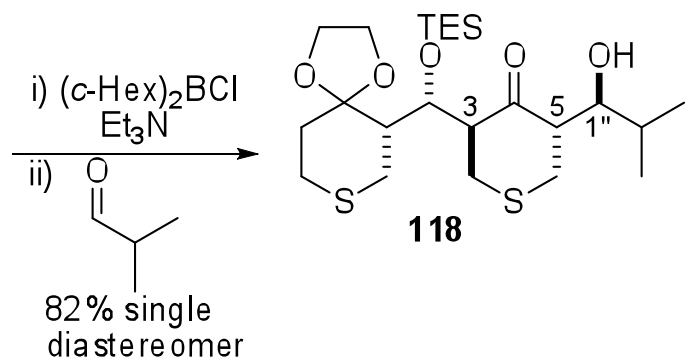

118

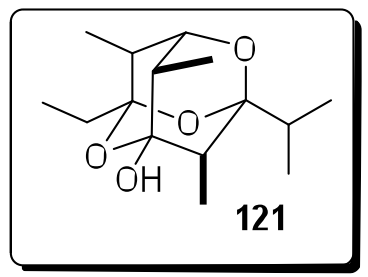

i) IBX / DMSO

ii) $\mathrm{FeCl}_{3} \cdot 6 \mathrm{H}_{2} \mathrm{O}$

$12 \mathrm{~h}$ reflux

$63 \%$

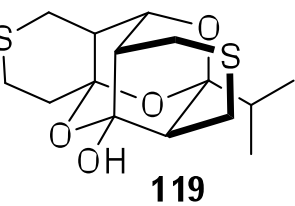

119

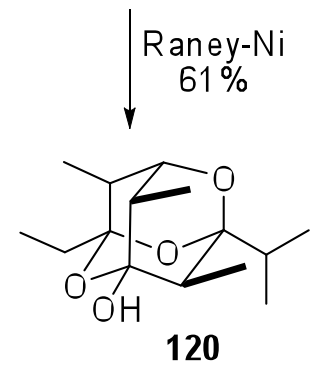

The mechanism for the isomerization of $\mathbf{1 2 0}$ to $\mathbf{1 2 1}$ involved a ring opening of the trioxaadamantane 120 to initially produce hemiacetal 123 that would be in equilibrium with the open form 122 and the other three hemiacetal forms 124, 125, and 126 (Scheme 2.5). The more

\footnotetext{
${ }^{\S}$ Preparation of the TES deprotected $( \pm)-\mathbf{1 0 2}$ was optimized to produce $10 \mathrm{~g}$ of product in $81 \%$ yield. ${ }^{39}$
} 
stable trioxaadamantane $\mathbf{1 2 1}$ would result from cyclization of $\mathbf{1 2 5}$. In addition to this isomerization process, other side reactions could occur, which in principle are responsible of the reduced yield of $\mathbf{1 2 1}$. For instance, a retro-Claisen reaction can occur from any of the formed hemiacetal forms 123-126. Sequentially, the retro-Claisen product 128 can undergo elimination to produce the enone 129. Additionally, the hemiacetal forms are susceptible to dehydration furnishing dihydropyrone 127.

Scheme 2.5 Isomerization of trioxaadamantane 120 to 121 under basic conditions.

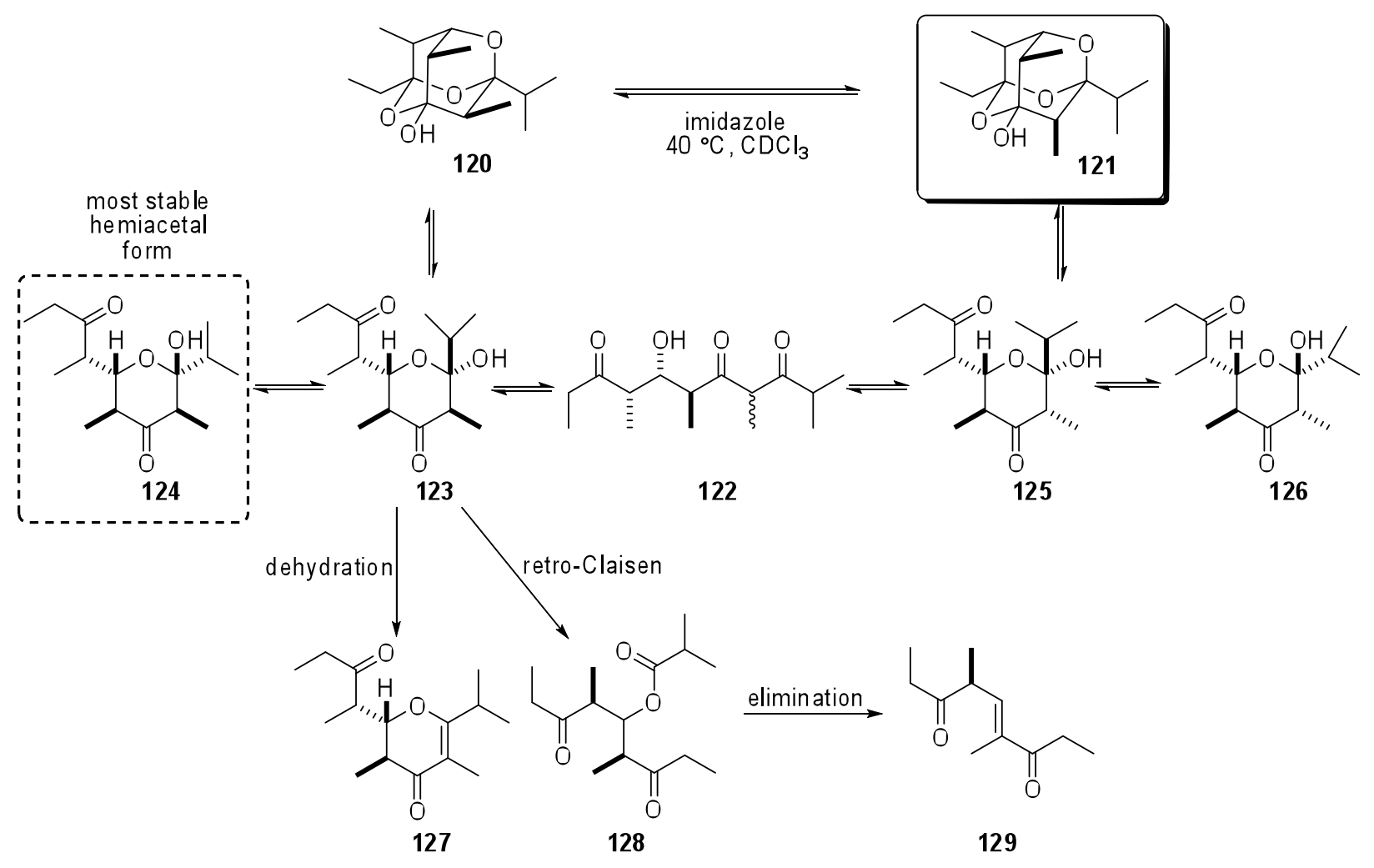

In order to gain more insight about the equilibration process, a sample of trioxaadamantane 120, was exposure to imidazole in $\mathrm{CDCl}_{3}$ at $40{ }^{\circ} \mathrm{C}$ and its isomerization was followed by ${ }^{1} \mathrm{H}-\mathrm{NMR}$ (Table 2.1). After 8 days, the reaction was worked up and fractionated. During this process, the formation of trioxaadamantane 121 and hemiacetal 124 were observed along with 127, 128, and 129. Plotting the relative amounts of $\mathbf{1 2 0}, \mathbf{1 2 1}$, and $\mathbf{1 2 4}$ as a function of 
time (Chart 2.1) revealed that the isomerization reached equilibrium after $96 \mathrm{~h}$ with a $6: 1$ ratio of trioxaadamantanes 121:120. At longer reaction times the amount of 121 was reduced because there were inceasing amounts of other products formed by irreversible reactions (i.e. retroClaisen, dehydration, elimination).

Table 2.1 Isomerization of trioxaadamantane 120 in $\mathrm{CDCl}_{3}$.

\begin{tabular}{ccccccc}
\hline & \multicolumn{7}{c}{ components present (\% by ${ }^{1} \mathrm{H}$ NMR) } \\
\cline { 2 - 7 } Time & $\mathbf{1 2 0}$ & $\mathbf{1 2 8}$ & $\mathbf{1 2 9}$ & $\mathbf{1 2 4}$ & $\mathbf{1 2 7}$ & $\mathbf{1 2 1}$ \\
\hline 0 & 100 & 0 & 0 & 0 & 0 & 0 \\
\hline 17 & 58 & 4 & 0 & 16 & 0 & 21 \\
\hline 41 & 27 & 12 & 0 & 10 & 7 & 44 \\
\hline 70 & 14 & 15 & 3 & 7 & 5 & 57 \\
\hline 96 & 10 & 17 & 4 & 6 & 5 & 58 \\
\hline 142 & 8 & 19 & 7 & 5 & 7 & 53 \\
\hline 169 & 8 & 21 & 10 & 3 & 7 & 51 \\
\hline 209 & 8 & 21 & 12 & 4 & 9 & 45 \\
\hline$a$ & 9 & 20 & 12 & 6 & 8 & 46 \\
\hline$b$ & 6.5 & 17 & 5 & 8 & 7 & 40 \\
\hline
\end{tabular}

${ }^{a}$ Crude product obtained after $210 \mathrm{~h} .{ }^{b}$ Isolated products from crude.

Chart 2.1 Isomerization of trioxaadamantane 120 in $\mathrm{CDCl}_{3}$.

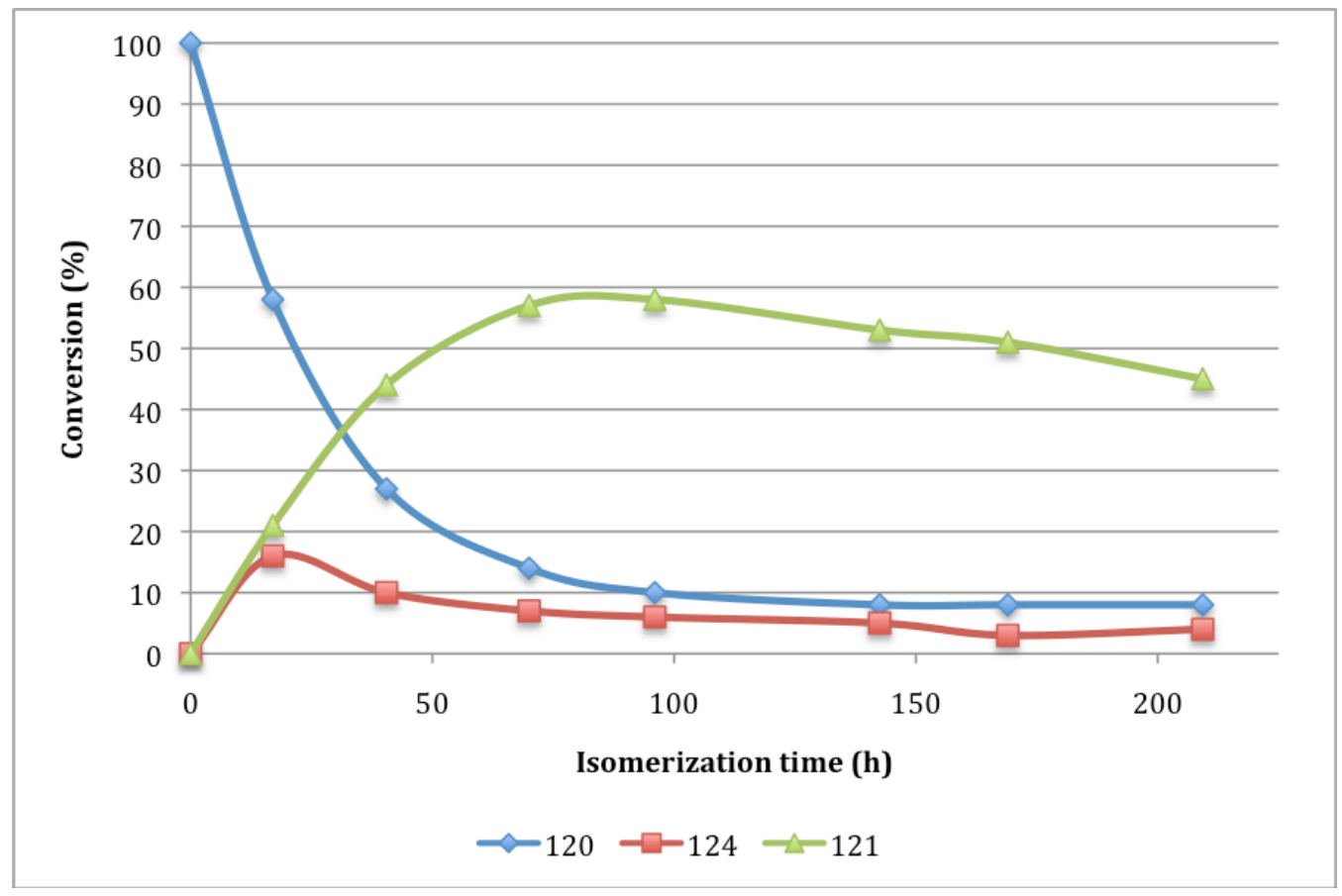




\subsubsection{The 3-benzyloxy-2-methylpropyl analogue (from the Roche ester)}

With the successful synthesis of 121, the next step was to investigate the formation of a trioxaadamantane bearing a (1-benzyloxy)-isopropyl substituent at C-9 using the sequence of reactions described in route A (Scheme 2.2). The boron mediated aldol reaction of enantiopure 102 with the Roche ester-derived aldehyde 29 produced a single diastereomer in $82 \%$ yield. Oxidation of the alcohol with IBX in DMSO for $5.5 \mathrm{~h}$ followed by deprotection of the TES and acetal groups by treatment with $\mathrm{FeCl}_{3} \cdot 6 \mathrm{H}_{2} \mathrm{O}$ for $12 \mathrm{~h}$ produced the desired trioxadithiopentacycle 131 in 58\% yield over 2 steps. Raney-Ni desulfurization of $\mathbf{1 3 1}$ provided a mixture of trioxaadamantane $\mathbf{1 3 3}$ and its debenzylated form $\mathbf{1 3 2}$ in low yield. Surprisingly, isomerization of $\mathbf{1 3 3}$ in the presence of imidazole at $40{ }^{\circ} \mathrm{C}$ gave only hemiacetal 134 by ${ }^{1} \mathrm{H}$ NMR without evidence for the presence of the expected 116.

Scheme 2.6 Approach to trioxaadamantane 116 from 102 and Roche ester-derived aldehyde 29.

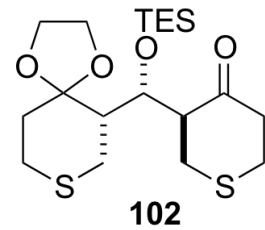

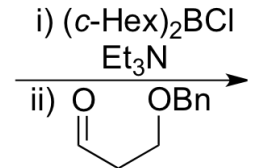<smiles>CC(C)CO[C@@H](C1CSCC(C(O)C(C)CO)C1=O)[C@H]1CSCCC12OCCO2</smiles>

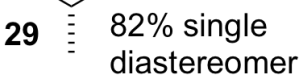
130 diastereomer

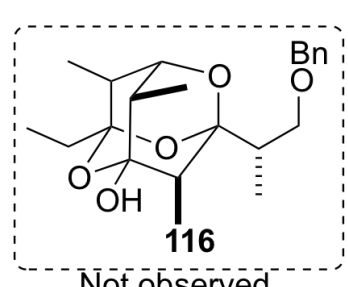

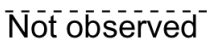
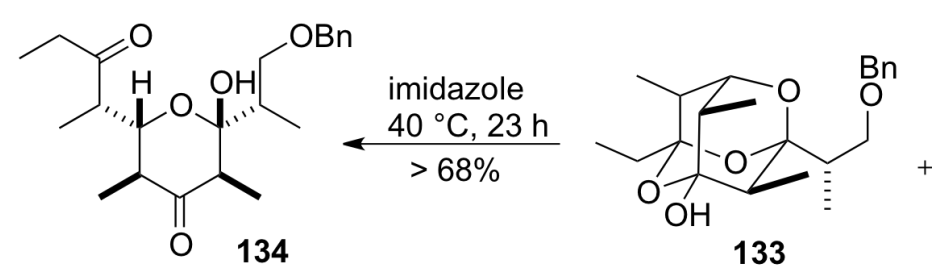

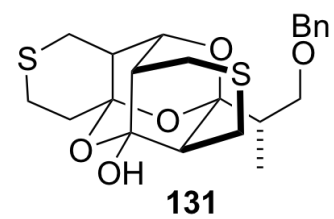

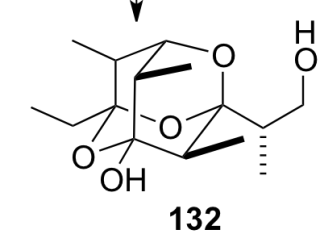


Because of the problems encountered in the formation of the trioxadithiopentacycle $\mathbf{1 3 1}$ and its subsequent desulfurization with Raney-Ni, the possibility for preparation of a trioxaadamantane such as $\mathbf{1 1 6}$ employing route B (Scheme 2.2) was considered.

\subsubsection{Trioxaadamantanes from 2-substituted 7-hydroxy-4,6,8-trimethylundecane-3,5,9- trione precursors}

\subsubsection{7-hydroxy-2,4,6,8-tetramethylundecane-3,5,9-trione precursor}

To study route B in Scheme 2.2, the precursor $\mathbf{1 3 5}$ was prepared by desulfurization of aldol 118 in 92\% yield. Subsequently, the protecting groups (i.e., TES and ethylene acetal) were hydrolyzed by treatment with $\mathrm{FeCl}_{3} \bullet 6 \mathrm{H}_{2} \mathrm{O}$ in acetone at room temperature for $1 \mathrm{~h}$ to afford $\mathbf{1 3 6}$ in $72 \%$ yield. Reaction of $\mathbf{1 3 6}$ with TESOTf was attempted to determine which of the two alcohols was more reactive. At moderate conversion the C-9 protected 137 was produced selectively in $50 \%$ yield along with unreacted starting material suggesting that selective oxidation of the C-9 alcohol in diol $\mathbf{1 3 6}$ could be achieved.

Scheme 2.7 Formation of trioxaadamantane system 121 following route B.

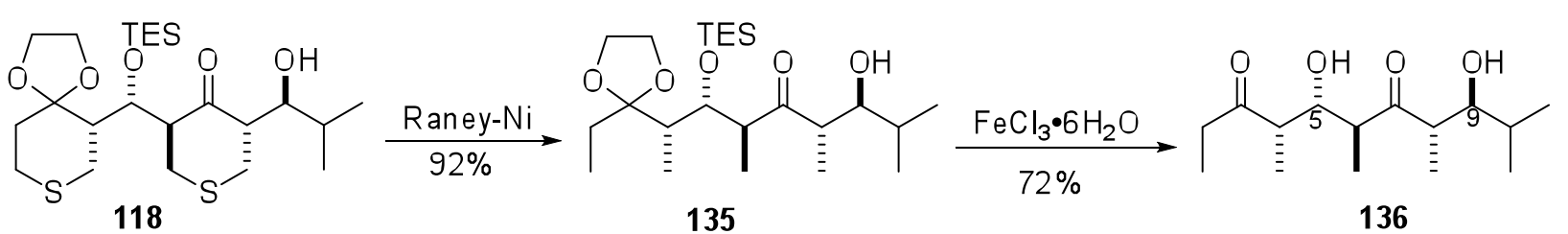
118 135

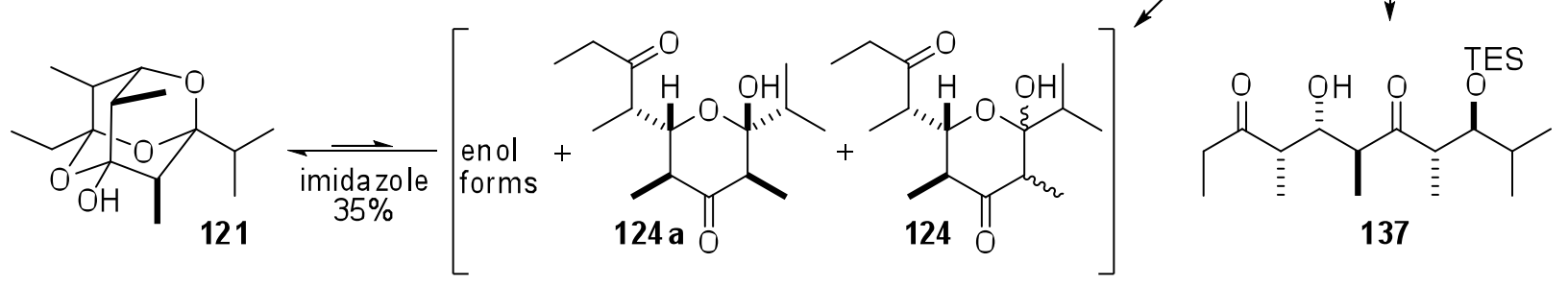

As anticipated, diol 136 was oxidized with DMP observing predominantly a selective oxidation at C-9 to produce the 5-hydroxy-3,7,9-trione as a mixture of three hemiacetal forms (i.e., 124 and 124a) along with minor amounts of other tautomers (i.e. enol and keto forms). 
Submission of this mixture of tautomers to imidazole at $40{ }^{\circ} \mathrm{C}$ in $\mathrm{CDCl}_{3}$, afforded the expected trioxaadamantane 121. Monitoring the isomerization by ${ }^{1} \mathrm{H}-\mathrm{NMR}$ indicated that the maximum amount of 121 (ca. 70\%) was present after ca. 2 days; Table 2.2). After a reaction time of $125 \mathrm{~h}$, 121 was isolated in $35 \%$ yield.

Table 2.2 Isomerization to trioxaadamantane $\mathbf{1 2 1}$ in $\mathrm{CDCl}_{3}$.

\begin{tabular}{ccccccc}
\hline & \multicolumn{7}{c}{ components present (\% by $\left.{ }^{\mathrm{I}} \mathrm{H}-\mathrm{NMR}\right)$} \\
\cline { 2 - 8 } Time (h) & $\mathbf{1 2 2}$ & $\mathbf{1 2 8}$ & $\mathbf{1 2 9}$ & $\mathbf{1 2 4}$ & $\mathbf{1 2 7}$ & $\mathbf{1 2 1}$ \\
\hline 21 & 0 & 16 & 0 & 9 & 7 & 68 \\
\hline 53 & 0 & 18 & 0 & 4 & 7 & 71 \\
\hline 71 & 0 & 18 & 3 & 4 & 8 & 67 \\
\hline 116 & 0 & 20 & 5 & 4 & 8 & 63 \\
\hline $\mathrm{a}$ & 7 & 16 & 4 & 5 & 7 & $61(35)^{\mathrm{b}}$ \\
\hline
\end{tabular}

${ }^{\mathrm{a}}$ Crude product after $125 \mathrm{~h} .{ }^{\mathrm{b}}$ Isolated product from crude.

\subsubsection{2-Methylidene precursor}

Raney-Ni desulfurization of the tetrapropionate unit (-)-102 afforded the enantioenriched ketone $(+)-109$ in $85 \%$ yield (Scheme 2.8). A boron mediated aldol reaction of $(+)-109$ with methacrolein produced $\mathbf{1 3 8}$ as a single diastereomer in 55\% yield. Deprotection of the TES and ethylene acetal groups was achieved with $\mathrm{FeCl}_{3} \cdot 6 \mathrm{H}_{2} \mathrm{O}$ to give diol 139 in $52 \%$ yield. Although attempted selective oxidation of $\mathbf{1 3 9}$ with $\mathrm{MnO}_{2}$ did not produce the desired product, treatment with DMP was successful. The resulting product 140, a mixture of tautomers, was directly submitted to imidazole in $\mathrm{CDCl}_{3}$ at room temperature for $19 \mathrm{~h}$ to give the retro-Claisen product 141 in $24 \%$ yield as the only isolable material without evidence of the presence of the desired trioxaadamantane 114. In view that those results were not promising for the formation of the 2 propenyl substituted trioxaadamantane system, it was decided to investigate other suitable substituents at C-9. 
Scheme 2.8 Approach to a trioxaadamantane system bearing a 2-propenyl substituent.

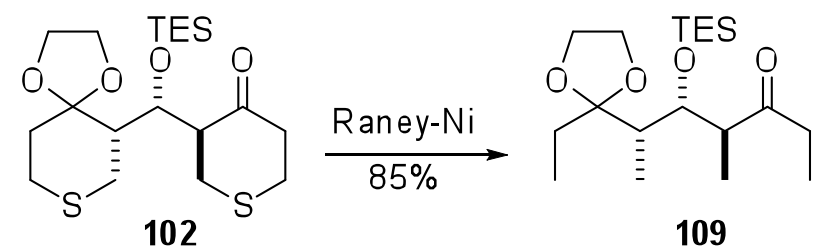

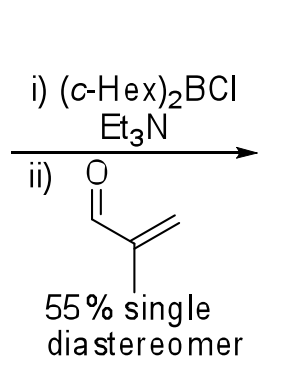<smiles>C=C(C)C(=O)OC(C(C)C(=O)O)C(C)C(=O)CC</smiles>

141

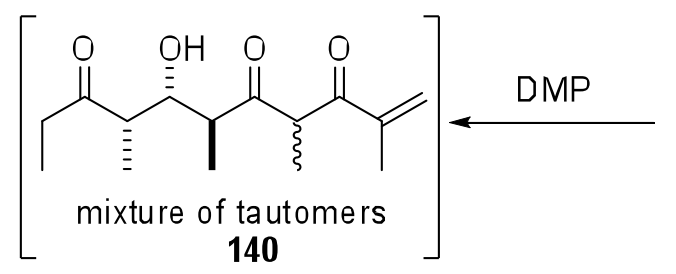<smiles>C=C(C)[C@H](O)[C@@H](C)C(=O)C(C)[C@H](O)[C@@H](C)C(=O)CC</smiles><smiles>C=C(C)[C@H](O)[C@@H](C)C(=O)C(C)[C@@H](O[Si])[C@@H](C)C1(CC)OCCO1</smiles>

\subsubsection{2-Benzyloxymethyl precursors (from the Roche ester)}

Following route B in Scheme 2.2, aldol reaction of the Roche ester-derived aldehyde 29 with the enantioenriched ketone (+)-109 via its $\mathrm{Ti}$ 'ate' or Li enolate produced keto alcohol 142 as a mixture of 3 or 4 diastereomers. In a three step procedure, hydrolysis of the TES and ethylene acetal protecting groups in $\mathbf{1 4 2}$ followed by chemoselective DMP oxidation of the resulting diol and then exposure to imidazole produced mainly hemiacetal 134 along with traces of the desired trioxaadamantane 116 (Scheme 2.9).

Scheme 2.9 Approach to trioxaadamantane 116 from Roche ester-derived aldehyde 29.

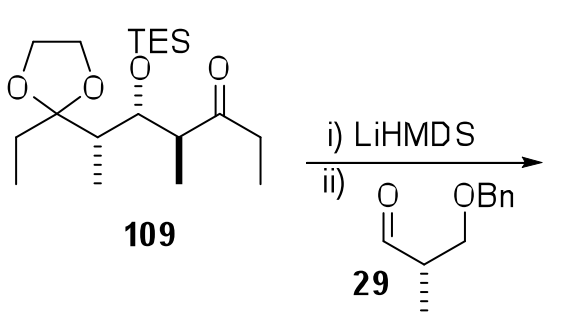

$80 \% 4$ diastereomers<smiles>CCC1([C@@H](C)[C@H](OC(F)(F)F)C(C)C(=O)C(C)C(O)[C@H](C)COc2ccccc2)OCCO1</smiles>

142
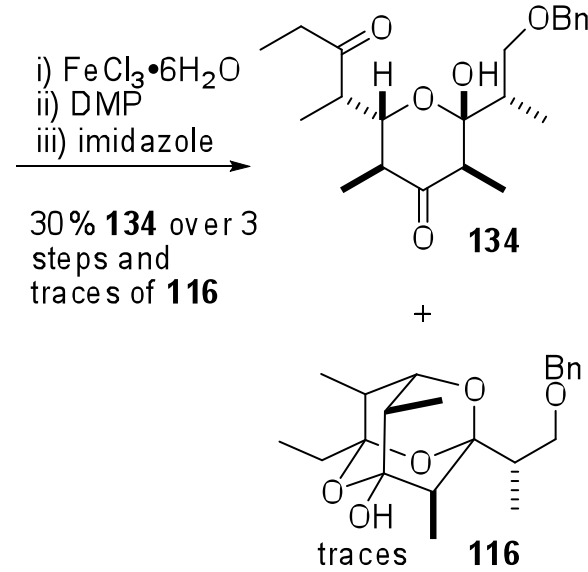
Several experiments were performed with hemiacetal 134 with the objective of inducing its isomerization to the trioxaadamantane 116 (Scheme 2.10). Exposure of hemiacetal 134 to imidazole at $40{ }^{\circ} \mathrm{C}$ for $33 \mathrm{~h}$, provided recovered hemiacetal 134 in ca. $75 \%$ with traces of the desired trioxaadamantane 116 together with other species (e.g., retro-Claisen and elimination products). It was hypothesized that hemiacetal form $\mathbf{1 3 4}$ could be stabilized by H-bonding, thereby disfavouring the trioxaadamantane form 116. Therefore, it was proposed that the use of a polar solvent for the isomerization step (i.e. THF or $\mathrm{MeOH}$ ), might disrupt the putative intramolecular H-bond in hemiacetal 134, and facilitate the formation of the desired trioxaadamantane 116. When the hemiacetal 134 was submitted to imidazole in refluxing THF or $\mathrm{MeOH}$ for $1 \mathrm{~h}$, the starting hemiacetal form 134 remained as the major compound in the mixture. Motivated by Paterson's report on the synthesis of muamvatin, ${ }^{36}$ where their respective hemiacetal (76 in Scheme 1.9) produced the desired trioxaadamantane ring system on exposure to silica, a sample of hemiacetal $\mathbf{1 3 4}$ was adsorbed on a $\mathrm{SiO}_{2}$ PTLC plate and extracted after 18 h. The resulting mixture consisted of hemiacetal 134 (ca, 40\%), desired trioxaadamantane system 116 (ca. 15\%) and other species (e.g. retro-Claisen and/or elimination products; ca. 45\%) by ${ }^{1} \mathrm{H}$ NMR. However, these results were not very promising because the hemiacetal 134 was always the predominant component after attempted isomerization and, at best, only a small amount of the desired trioxaadamantane $\mathbf{1 1 6}$ was formed along with significant amounts of side products. Concluding that this method would not provide synthetically useful amounts of trioxaadamantane 116, a final approach involved the use of a TIPS protecting group to disfavour the putative stabilizing intramolecular H-bond in 134. The TIPS protected trioxaadamantane $\mathbf{1 4 3}$ was prepared by desulfurization of $\mathbf{1 3 1}$ (in Scheme 2.6) followed by treatment with TIPS-OTf. Trioxaadamantane $\mathbf{1 4 3}$ was stable to imidazole in $\mathrm{CDCl}_{3}$ at room temperature for $10 \mathrm{~h}$; however, 
after 5 days at $40{ }^{\circ} \mathrm{C} 143$ was completely consumed and hemiacetal 144 was the only isolated product.

Scheme 2.10 Attempts for folding hemiacetal 134 or 144 to the trioxaadamantane system

\section{6 or 145 .}

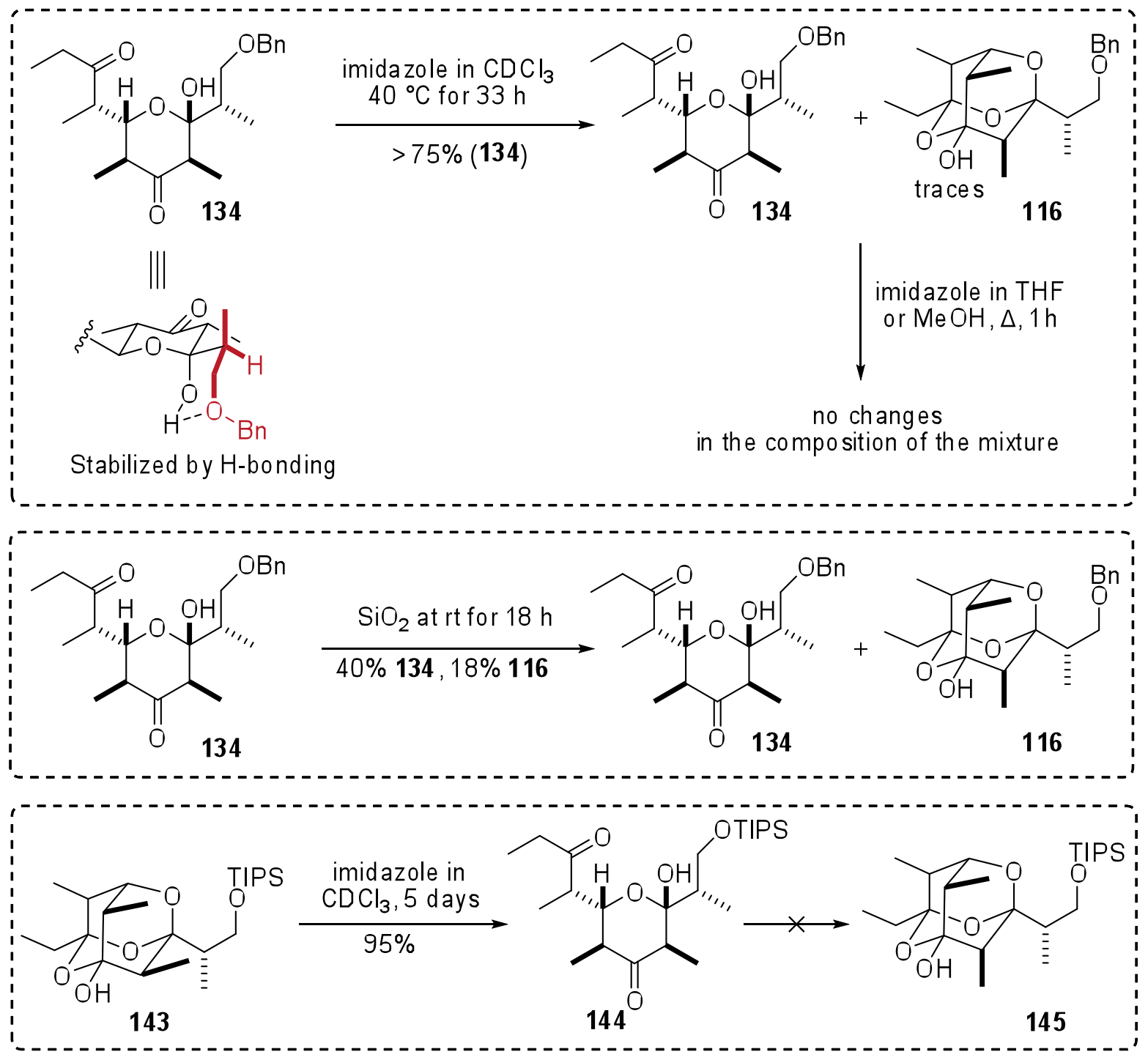

The unfavourable results in these experiments deserved a careful conformational analysis in order to find an explanation for the observed outcomes. At this time, it was hypothesized that the configuration at $\mathrm{C}-10$ could be playing an important role in the formation of the trioxaadamantane system. Simple molecular mechanics calculations, employing the software 
Spartan, $^{* *}$ on the trioxaadamantanes 148 and 10-epi-148 suggested that the latter was ca. 0.5 Kcal $/$ mol more stable (Figure 2.2). Similar calculations on the most stable hemiacetal tautomers 146 and 10-epi-146 suggested that $\mathbf{1 4 6}$ was considerably more stable $(4.4 \mathrm{Kcal} / \mathrm{mol})$ primarily due to a favourable H-bond between the hemiacetal $\mathrm{OH}$ and methyl oxygen. The above calculations suggested that the unfavourable equilibrium observed in the attempted formation of 148 might be reversed in the 10-epi diastereomer. To test that hypothesis, the preparation of 10epi-116 following route B in Scheme 2.2 was attempted.

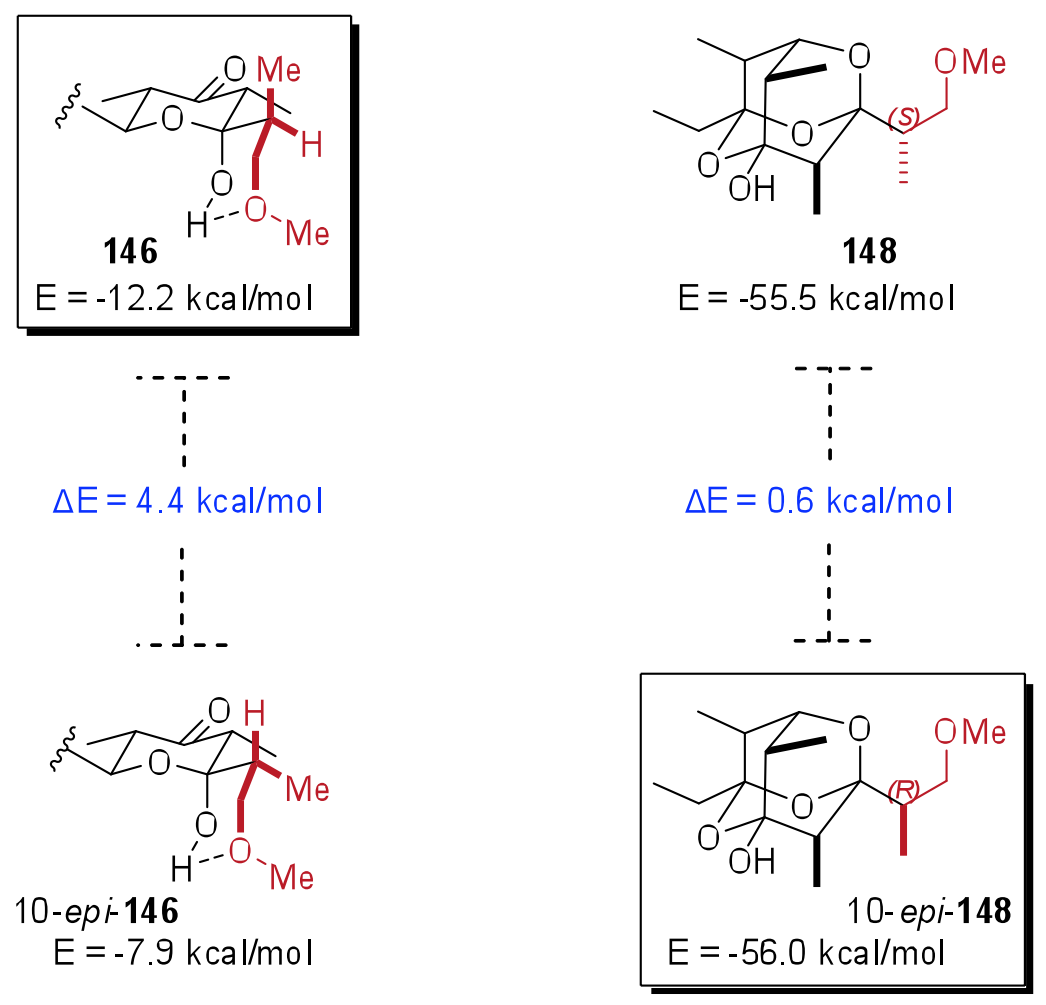

Figure 2.2 Ground state energies for the equilibrium conformer of 146, 10-epi-146, 148, and 10-epi-148.

\footnotetext{
** All calculations were performed using the software Spartan '08 V 1.1.2 for Mac from Wavefunction, Inc. The calculations were performed by finding the equilibrium conformer using Molecular Mechanics / MMFF (Merck Molecular Force Field) model and the ground state energies were taken.
} 
The preparation of 10-epi-116 would require ketone 109 and ent-29; however, ent-10-epi116 could be prepared from ent-109 and 29. Experimentally, the second option was used because aldehyde 29 was on hand and both enantiomers of 109 were available..$^{\dagger \dagger}$
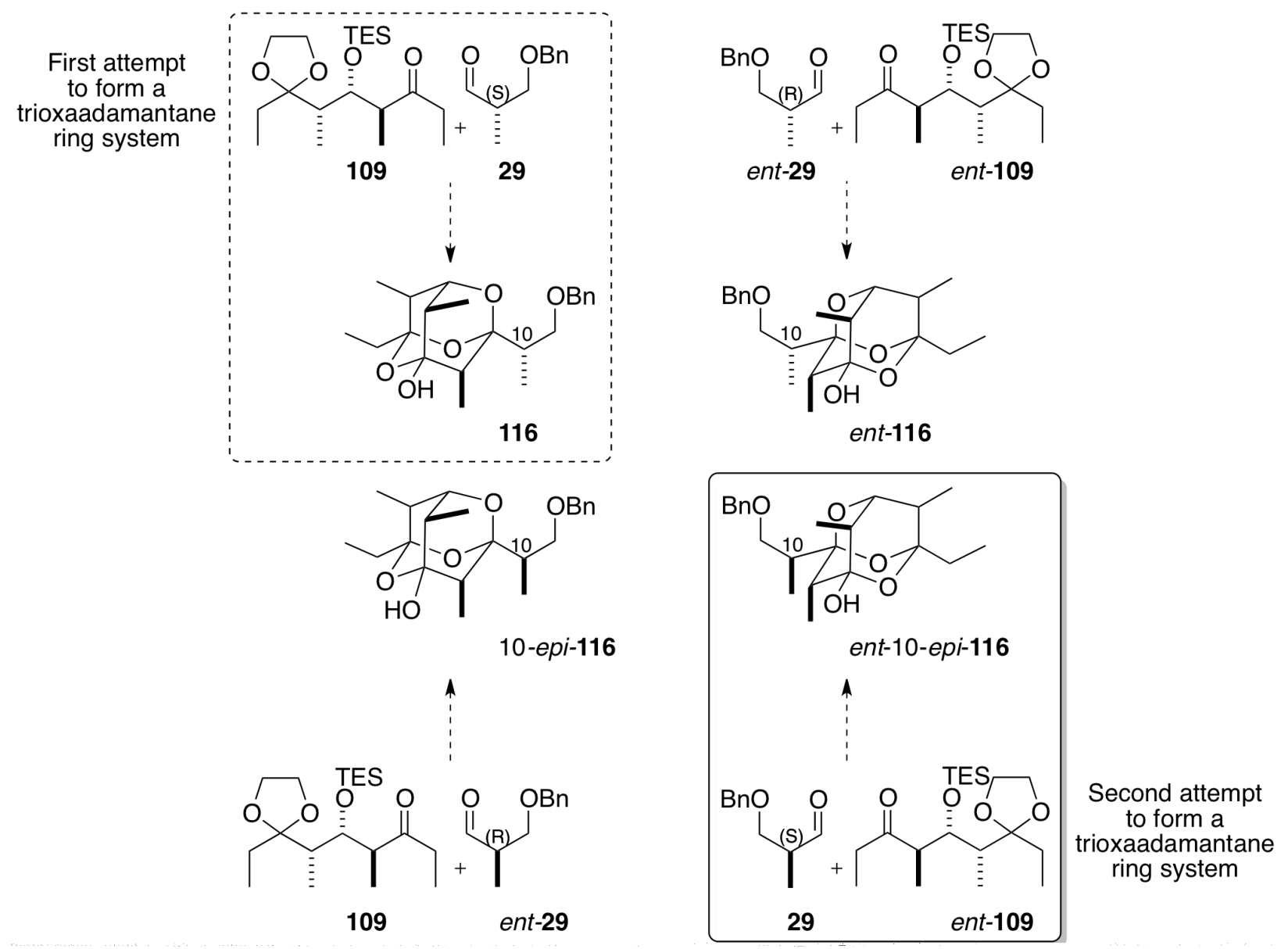

Figure 2.3 Starting materials to prepare trioxaadamantanes 116, ent-116, 10-epi-116, and ent-10-epi-116.

Following the same route as illustrated in Scheme 2.9, aldol reaction of $\mathbf{2 9}$ with the Ti 'ate' or Li enolates of ent-109 gave a mixture of aldol adducts 149 (79-81\%). Gratifyingly, after TES and acetal deprotection, DMP oxidation and isomerization with imidazole, 149 was converted to the desired trioxaadamantane ent-10-epi-116 in $42 \%$ overall yield.

\footnotetext{
${ }^{\dagger}$ The preparation of the Roche ester-derived aldehyde $\mathbf{2 9}$ required 3 steps starting from the commercially available Roche ester. ${ }^{46}$
} 
Scheme 2.11 Synthesis of the trioxaadamantane ent-10-epi-116.

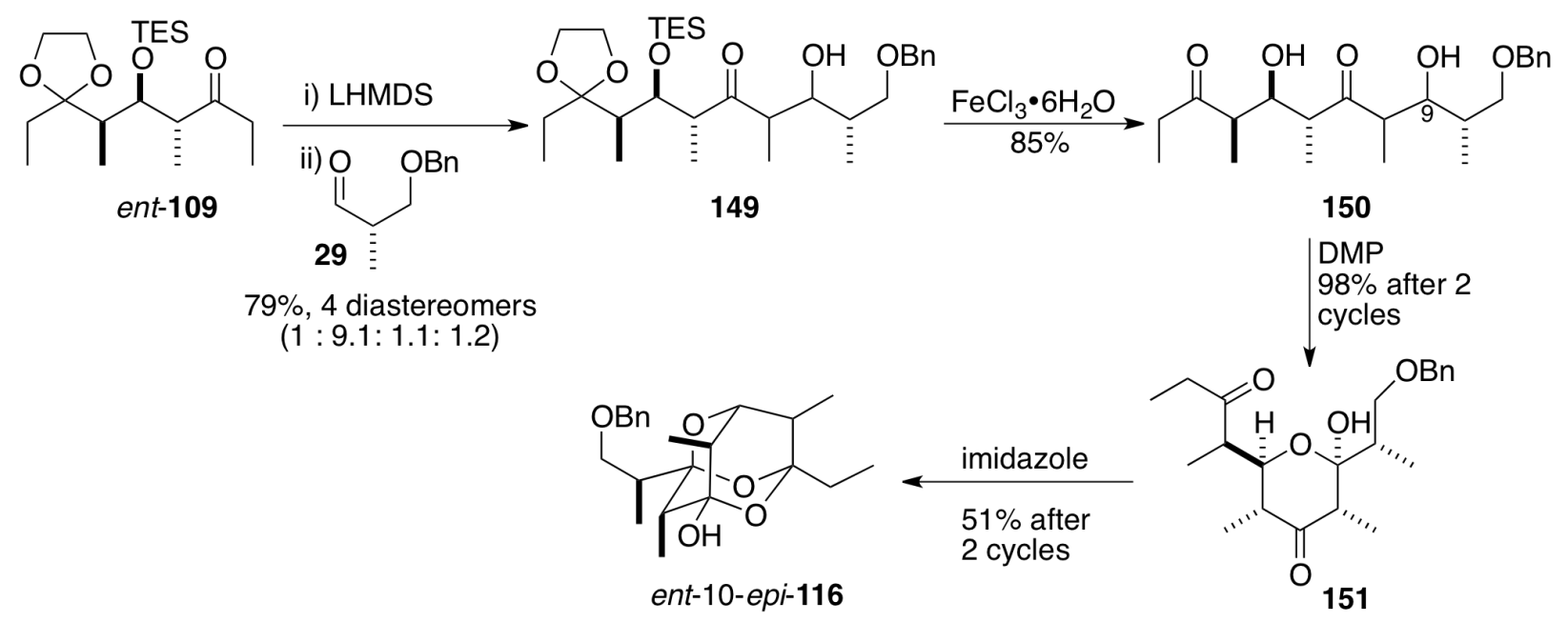

In view of these experimental results and the molecular mechanics calculations, it seemed clear that H-bonding was playing an important role for the stabilization of certain hemiacetal forms, thus favouring the equilibrium towards the hemiacetal $\mathbf{1 3 4}$ in the first attempt (Scheme 2.9) and towards the trioxaadamantane ent-10-epi-116 in the second attempt (Scheme 2.11). Comparing hemiacetals 134 and 10-epi-134 (Figure 2.4) where both have all the large groups in equatorial orientations in a chair conformation, $\mathrm{H}$-bonding between the anomeric $\mathrm{OH}$ and $\mathrm{OBn}$ group in 134 can occur without any syn pentane interactions in the molecule. In contrast, the same H-bonding in 10-epi-134 results in a syn pentane interaction between the methyl groups as illustrated in Figure 2.4. 

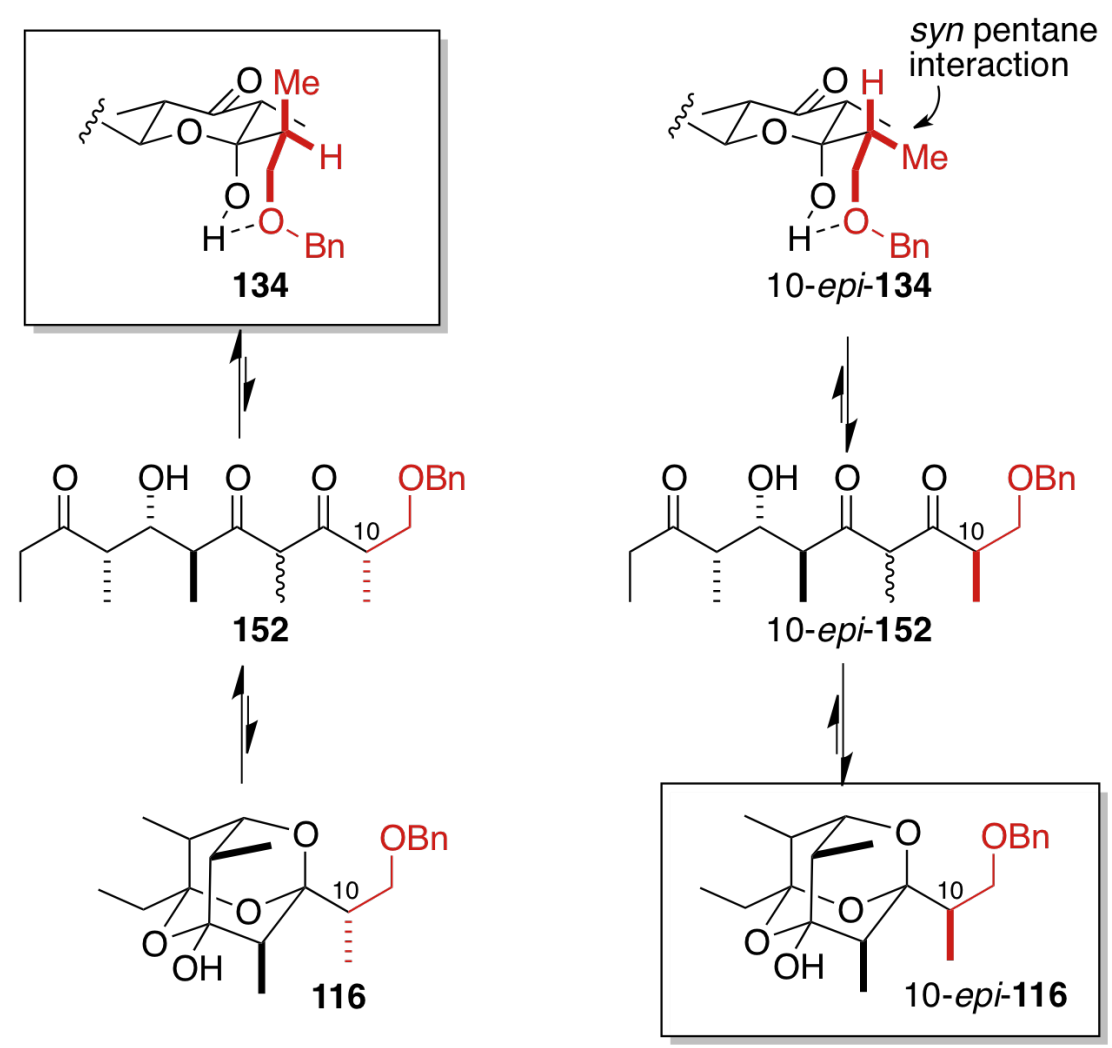

Figure 2.4 Formation of $\mathbf{1 3 4}$ and 10-epi-116 after isomerization with imidazole.

\subsubsection{2-(4-benzyloxytetrahydro-2H-thiopyran-3-yl) precursor}

In view of the successful preparation of trioxaadamantane ent-10-epi-116, the formation of a trioxaadamantane with a 2-(4-benzyloxytetrahydro-2H-thiopyran-3-yl) substituent could be another possibility towards the synthesis of caloundrin B (3) because this would have all the necessary carbons in place to generate 10-epi-95 (Scheme 2.3). The main question was if the trioxaadamantane could be formed with this relatively more hindered substituent. The preparation of the required aldehyde 159 began with a baker's yeast reduction of 154 to yield the enantioenriched syn- $\beta$-hydroxy ester 155 in $75 \%$ and $93 \%$ ee (Scheme 2.12$).{ }^{47}$ Subsequently, reduction of the ester 155 with $\mathrm{NaBH}_{4}$ produced diol 156 that was protected as its benzylidene acetal 157. Regioselective reduction of the acetal in 157 with DIBAL-H afforded the primary alcohol 158 that was treated with IBX to produce the desired enantioenriched aldehyde 159. 
Because 159 was prone to isomerization and decomposition (elimination) it was used immediately in the aldol reaction with $\mathbf{1 0 9 .}$

Scheme 2.12 Preparation of enantioenriched aldehyde 159.<smiles>COC(=O)C1CS(=[As])CCC1=O</smiles><smiles>C[As](C)(=S)OC(=O)C1CS([13CH3])([13CH3])CCC1O</smiles>

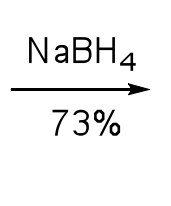<smiles>OCC1C[AsH2+]CCC1O</smiles><smiles>COC(OC)c1ccccc1</smiles><smiles>[13CH2]C1CCC2OC(c3ccccc3)OCC2C1</smiles><smiles>O=CC1CSCCC1OCc1ccccc1</smiles>
159
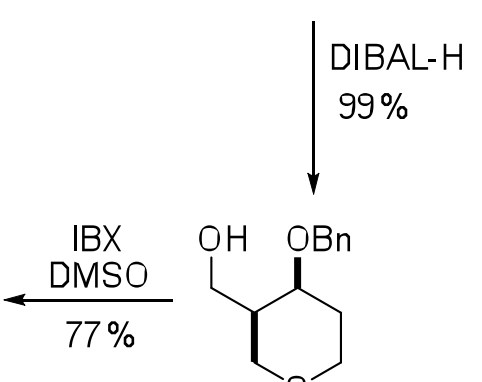<smiles></smiles>

Reaction of 159 with 109 via its $(Z)$-lithium enolate gave 160 as a mixture of at least three aldol adducts in $77 \%$ yield. This mixture of aldol adducts $\mathbf{1 6 0}$ was submitted to the standard three step procedure of $\mathrm{FeCl}_{3} \bullet 6 \mathrm{H}_{2} \mathrm{O}$ mediated deprotection of the TES and ethylene acetal groups, chemoselective oxidation of the resulting diol with DMP, and finally submission to imidazole; however, the hemiacetal product 161 was the only product isolated $(31 \%$ yield over 3 steps) without detection of the desired trioxaadamantane $\mathbf{1 6 2}$. 
Scheme 2.13 Approach to trioxaadamantane 162.

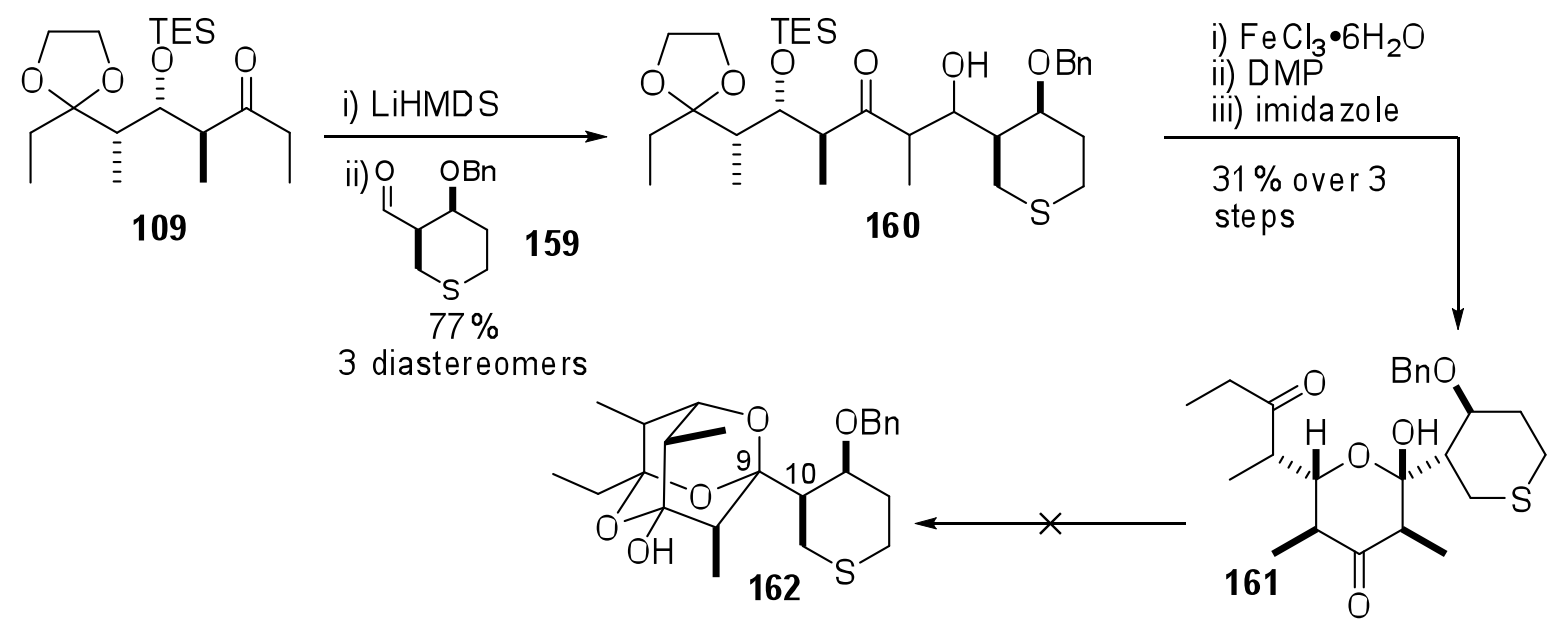

At this point, it seemed that the nature of C-9 had a profound effect on the facility to fold a trioxaadamantane ring system under thermodynamic control. It was concluded that the best option was to continue towards the synthesis of caloundrin B (3) via the trioxaadamantane system ent-10-epi-116, because from all previous attempts, this was the only system that would afford the preparation of synthetically useful amounts of the trioxaadamantane.

\subsubsection{Installing the correct configuration at $\mathrm{C}-10$ for caloundrin $\mathrm{B}$}

Despite several attempts to prepare a trioxaadamantane fragment suitable for application towards the synthesis of caloundrin B, only ent-10-epi-116 could be obtained in a reasonable yield. Therefore, it was decided to use ent-10-epi-116 towards the synthesis of ent-caloundrin B (ent-3). However, to pursue this objective, the configuration at C-10 in ent-10-epi-116 had to be corrected (Figure 2.5). 


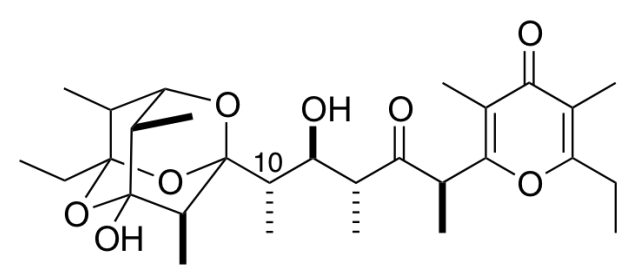

caloundrin B (3)

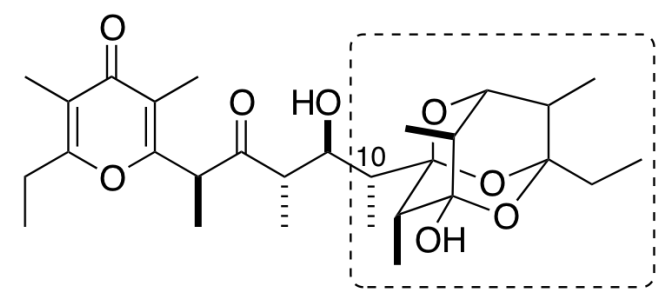

ent-caloundrin B (ent-3)

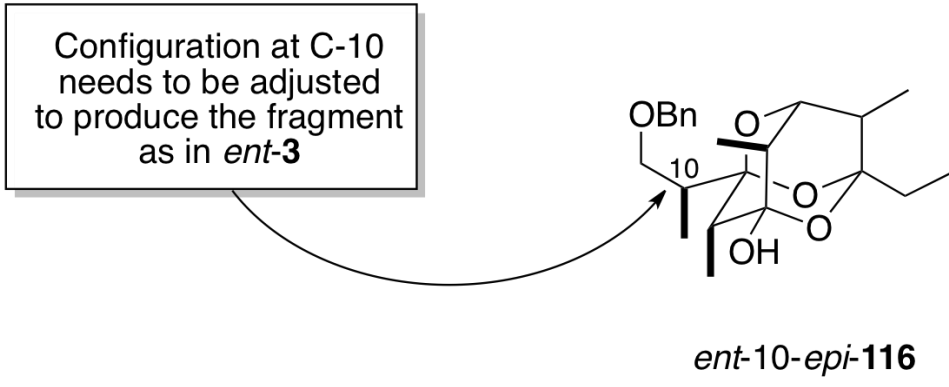

Figure 2.5 Structures of caloundrin B (3) and ent-3.

In order to prevent unfolding of the acid- and base-sensitive trioxaadamantane ring system in ent-10-epi-116, the alcohol was protected as its TMS ether by treatment with TMSOTf to furnish ent-10-epi-163 in $87 \%$ yield. Then debenzylation using $\mathrm{Pd} / \mathrm{C}, \mathrm{H}_{2}{ }^{48}$ of ent-10-epi-163 produced alcohol ent-10-epi-164 in $86 \%$ yield. At this point, efforts were directed towards elimination of the alcohol group in ent-10-epi-164 with the expectation that the desired relative configuration could be installed by hydroboration of the resulting alkene; however, all attempts under different conditions (i.e. selenation, ${ }^{49,50}$ mesylation) failed (Scheme 2.14). 
Scheme 2.14 Attempts to invert the configuration at C-10 of ent-10-epi-164 or ent-10epi-167.

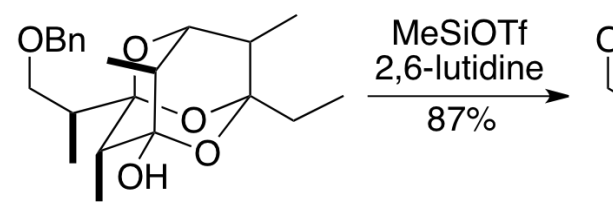

ent-10-epi-116

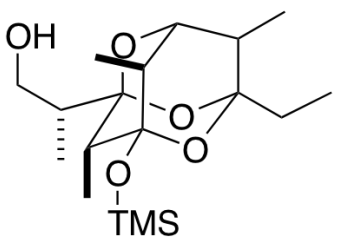

ent-164

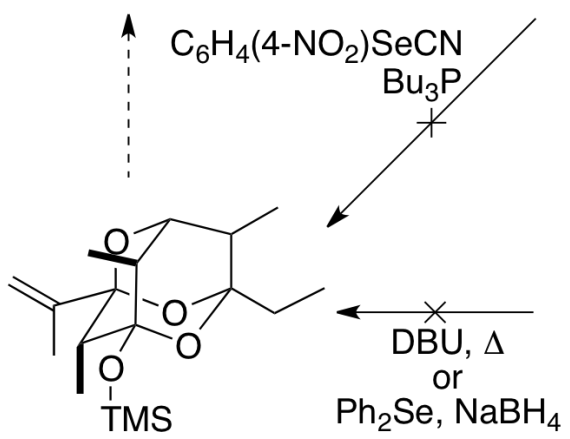

ent-10-epi-166

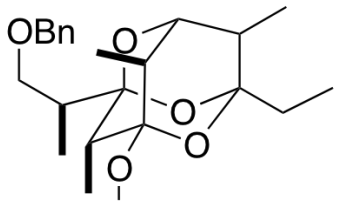

TMS

ent-10-epi-163

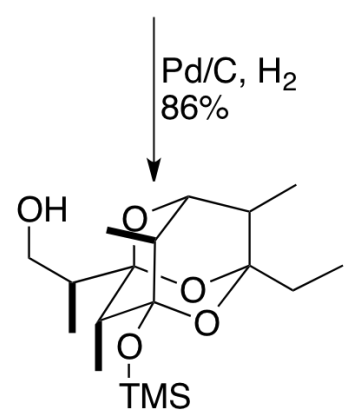

ent-10-epi-164
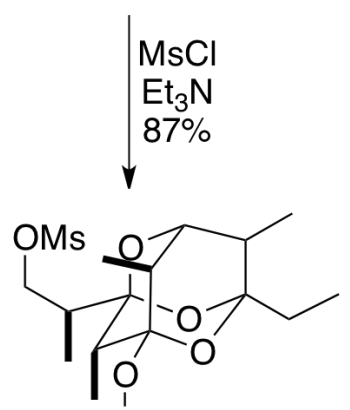

TMS

ent-10-epi-165

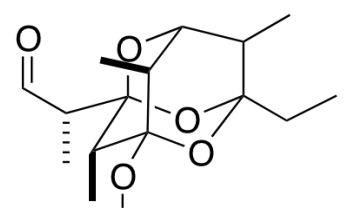

TMS

ent-167
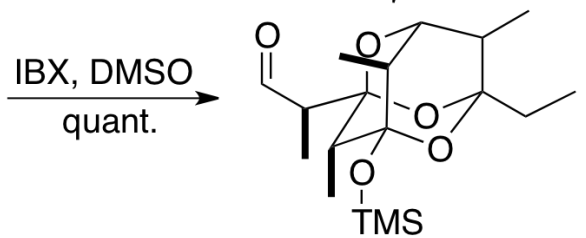

ent-10-epi-167

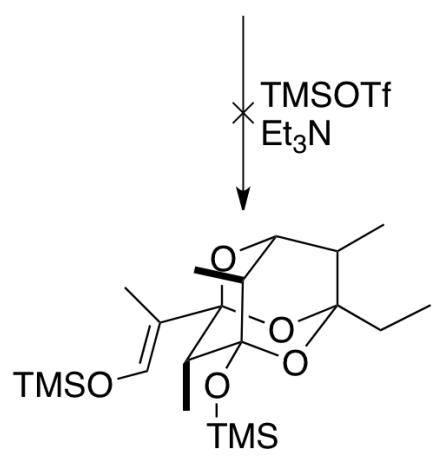

ent-10-epi-168

Oxidation of ent-10-epi-164 with IBX in $\mathrm{DMSO}^{51}$ successfully afforded aldehyde ent-10epi-167 in quantitative yield. It was attempted to form the enol ether ent-10-epi-167 with hopes of producing the desired aldehyde ent-167 by hydrolysis under kinetic control. Again, all attempts exploring this approach failed.

Finally, the isomerization of ent-10-epi-167 under basic conditions was investigated. When a solution of ent-10-epi-167 in $\mathrm{CDCl}_{3}$ was exposed to imidazole at $40{ }^{\circ} \mathrm{C}$ for 1 day, ${ }^{52}$ a separable 4:1 equilibrium mixture of ent-10-epi-167 and ent-167 was produced. Similarly, 
exposure of a solution of ent-10-epi-167 in DMSO to L-proline ${ }^{53}$ at room temperature for 10 days produced the same ratio of the two aldehydes. Despite the unfavourable equilibrium, submission of ent-10-epi-167 to six isomerization cycles allowed aldehyde ent-167 to be obtained in 49\% yield along with recovered ent-10-epi-167 in 28\% yield.

An alternative method for epimerizing C-10 was attempted with ketone ent-10-epi-95. This ketone was prepared from aldehyde ent-10-epi-167 by reaction with EtMgBr to afford essentially a single diastereomer of ent-10-epi-169 in $88 \%$ yield that was oxidized with IBX in $\mathrm{DMSO}^{51}$ to produce ketone ent-10-epi-95 in $99 \%$ yield. Unfortunately, ent-10-epi-95 proved to be quite stable and no isomerization was observed in the presence of imidazole in $\mathrm{CDCl}_{3}$. Nevertheless, the preparation of ent-10-epi-95 was useful in the study of aldol reactions with kinetic resolution (see Section 2.4.4).

Reaction of aldehyde ent-167 with EtMgBr produced ent-170 as a 4:1 mixture of the two possible diastereomers in $99 \%$ yield. Without separation, ent-170 was oxidized with IBX in $\mathrm{DMSO}^{51}$ to produce the desired ketone ent-95 in $87 \%$ yield (Scheme 2.15). The preparation of ent-95 opened the possibility to continue with the study of the next key step towards the synthesis of ent-3. 
Scheme 2.15 Preparation of ketones ent-10-epi-95 and ent-95.
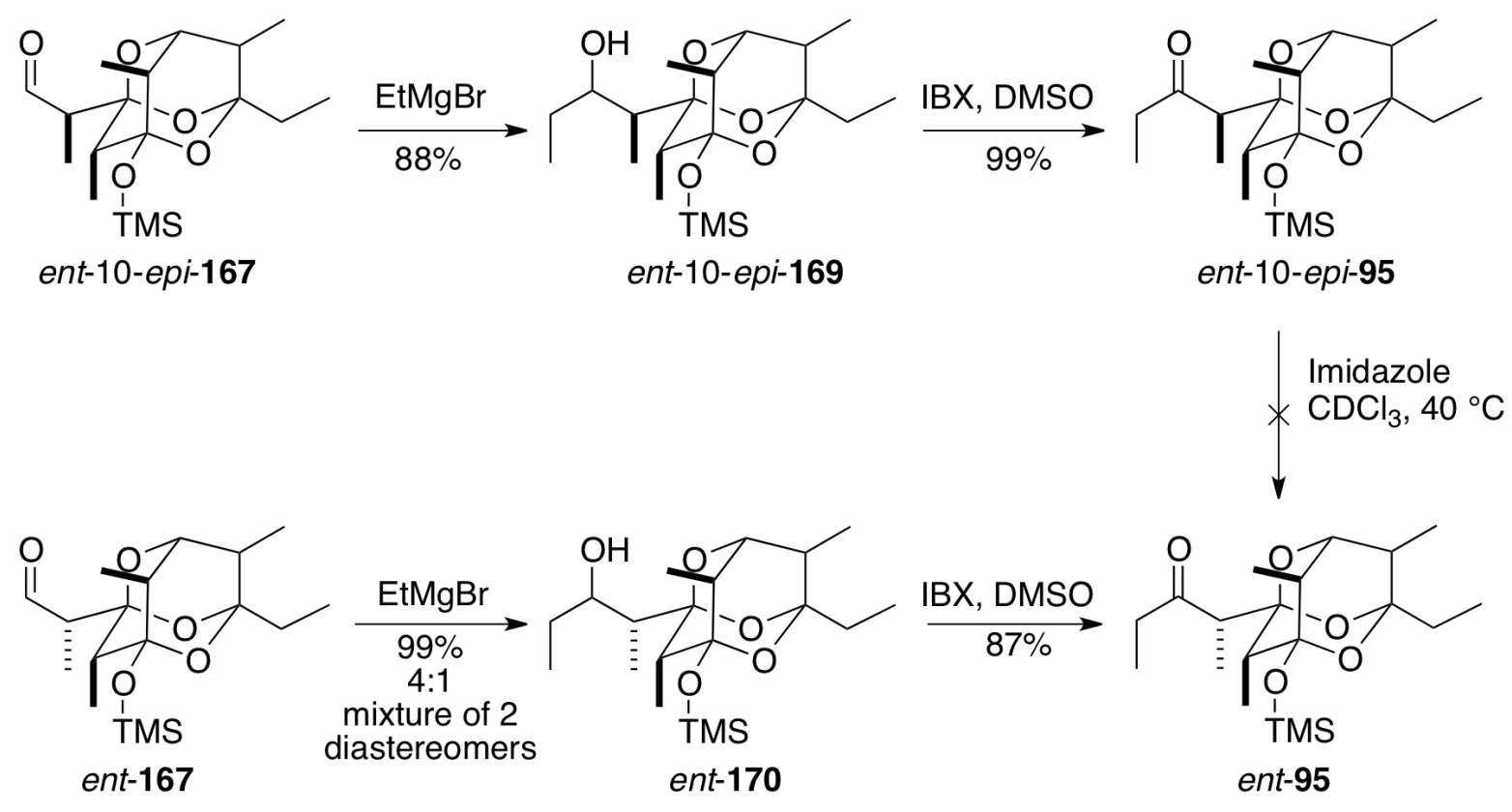

\subsection{Application of aldol coupling with kinetic resolution to the synthesis of caloundrin B}

\subsubsection{The thiopyran route to polypropionates: design of aldol reactions that proceed with kinetic resolution.}

The development of new strategies and their application in the synthesis of polypropionates is one of the main topics of research in the Ward group. A very solid methodology based on the aldol reaction of thiopyran units has been developed and applied to the synthesis of diverse marine polypropionates. ${ }^{29}$ My contribution to this area involved the study of aldol reactions that proceed with kinetic resolution. ${ }^{46}$

In all aldol reactions between two chiral fragments, three stereocontrol elements contribute to the stereochemical outcome of the resulting aldol products. These are: $i$ ) aldehyde diastereoface selectivity, $i$ ) enolate diastereoface selectivity, and iii) relative topicity of the aldol reaction. Therefore, if the three stereocontrol elements are highly selective, ${ }^{\dagger+}$ it would be possible

\footnotetext{
$\$$ In Heathcock's studies for acyclic stereoselection in aldol reactions he postulated that: "In reactions involving two chiral racemic compounds, the magnitude of mutual kinetic resolution depends upon the diastereoselectivity shown by the two reactants in their reactions with achiral reaction partners". Thus, application of the multiplicativity rule
} 
to predict which would be the stereochemical outcome of the major product by application of the multiplicativity rule. ${ }^{54-56}$

From previous studies in the Ward group, it was established that the enolate diastereoface selectivity of tetrapropionate aldol adducts 171 (Scheme 2.16) could be manipulated by the absence (i.e. 3,5-syn selectivity) or presence (i.e. 3,5-trans selectivity) of a protecting group on the $\mathrm{C}-1$ ' $\mathrm{OH}$ group. ${ }^{45}$ In addition, the diastereoface selectivity of the aldehyde $\mathbf{1 7 3}$ was shown to be highly Felkin selective; i.e., leading to products with a 1 ",6"-syn relative configuration. ${ }^{45}$ In this research, the development of conditions to switch the relative topicity $(5,1$ "'-anti or 5,1"-syn) of the aldol reactions between $( \pm)-\mathbf{1 7 1}$ and $( \pm)$-173 were studied. Thereafter, the optimized conditions for the aldol reactions were performed with enantiopure ketone $\mathbf{1 7 1}$ in order to achieve kinetic resolution. ${ }^{\S}$

High 5,1"-anti selectivity (i.e. 174, $s=15-20)$ was achieved in reactions between $( \pm)$-173 and the enol dicyclohexylborinates of the four diastereomeric aldol adducts $( \pm)-\mathbf{1 7 1}$, whereas high 5,1"-syn selectivity (i.e. 175, $s=10$-20) was achieved in the same reactions by using the Ti(IV) 'ate' enolates of $( \pm)-\mathbf{1 7 1}$ formed by reaction of the LDA-generated Li enolates with $\mathrm{Ti}\left(\mathrm{O}^{i} \mathrm{Pr}\right)_{4}$ (Scheme 2.16). The same aldol reactions using enantiopure ketones 171 with $( \pm)-\mathbf{1 7 3}$ proceeded with kinetic resolution allowing access to enantiopure aldol adducts $\mathbf{1 7 4}$ and $\mathbf{1 7 5}$, which are useful for further application in synthesis. In addition, this strategy for achieving kinetic resolution was thought to be applicable to aldol reactions with suitable substrates and to other related processes.

to calculate the kinetic resolution selectivities $\left(s=k_{\text {fast }} / k_{\text {slow }}\right)$ in aldol couplings of chiral reactants gives: $s=$ $(\mathrm{E} \bullet \mathrm{R} \bullet \mathrm{A}+\mathrm{E}+\mathrm{R}+\mathrm{A}) /(\mathrm{E} \bullet \mathrm{R}+\mathrm{E} \bullet \mathrm{A}+\mathrm{R} \bullet \mathrm{A}+1)$, where $\mathrm{E}=$ enolate diastereoface selectivity; $\mathrm{A}=$ aldehyde diastereoface selectivity; $\mathrm{R}=$ relative topicity of the coupling.

$\S \S$ This work was developed in collaboration with Mohammad M. Zahedi. 
Scheme 2.16 Rational design of aldol reactions with kinetic resolution.

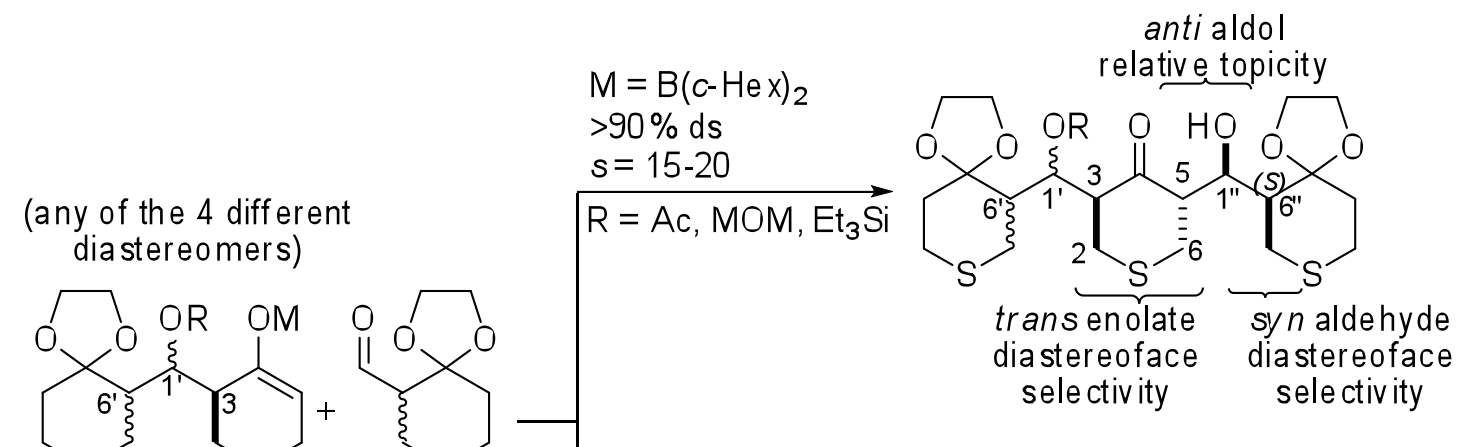
$( \pm)$ or enantiopure-172
$( \pm)-173$

$( \pm)$ or enantiopure-174

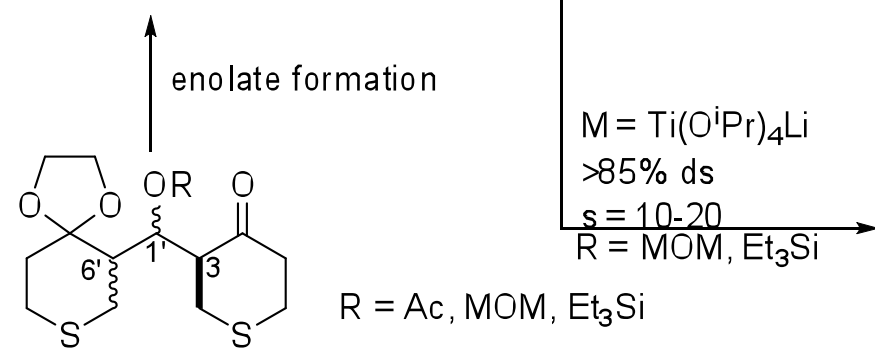

$( \pm)$ or enantiopure-171

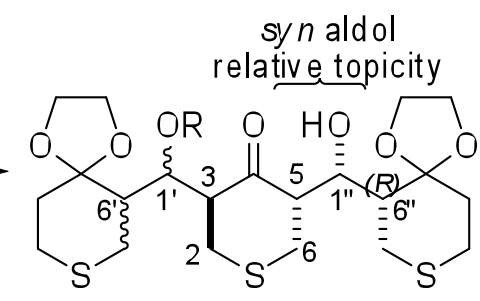

$( \pm)$ or enantiopure-175

\subsubsection{Non-linear effects in the enantiotopic group selectivity of aldol reactions of chiral reactants}

To identify conditions for kinetic resolution, reactions of racemic reactants $\mathbf{1 7 1}$ and $\mathbf{1 7 3}$ were screened under numerous conditions. When both reactants are racemic these reactions occur with mutual kinetic enantioselection (MKE) and appropriate analysis of the distribution of diastereomers formed allows determination of the ratio of rate constants in the related KR when one of the reactants is enantiopure and the other is racemic (i.e. $\left.s=k_{\text {fast }} / k_{\text {slow }}\right){ }^{57}$

After optimization of the reaction between $( \pm)-\mathbf{1 7 6}$ and $( \pm)-\mathbf{1 7 3}$ with $\mathrm{TiCl}_{2}\left(\mathrm{O}^{i} \mathrm{Pr}\right)_{2}$ to produce 5,1 "-syn selectivity, ${ }^{58}$ the same conditions were applied using enantioenriched enolate 177 (i.e. $>94 \%$ ee) and racemic $( \pm)-173$ in order to perform $\mathrm{KR}$ and produce enantioenrich aldol adduct 178. Surprisingly, the selectivity of this reaction did not follow the expected behaviour (i.e. $S R / S S=\mathrm{k}_{\mathrm{SR}} / \mathrm{k}_{\mathrm{SS}}$ ). 
Performing a series of aldol reactions of racemic $( \pm)-\mathbf{1 7 3}$ with ketone $\mathbf{1 7 6}$ of varying enantiomeric purities (Table 2.3, entries 1-7) demonstrated that the diastereoselectivity of the reaction decreased as the ee of $\mathbf{1 7 6}$ increased. In addition, similar results were observed when ketone aldol adduct (3,1'-syn, 6', 1'-anti $\mathbf{1 7 1}, \mathrm{R}=\mathrm{Ac})$ was used. ${ }^{* * *}$ Non-linear relationships between the enantiopurity of a reagent and the enantioselectivity of its reactions have been observed previously and are usually attributed to reaction mechanisms involved dimeric or oligomeric species. ${ }^{59-62}$ However, there appears to be no previous reports of a non-linear relationship between the enantiopurity of a reactant and its enantiomer selectivity in a kinetic resolution.

It is known that Ti(IV) species can exist as dimers in solution. ${ }^{63}$ Therefore, if dimeric $\mathrm{Ti}$ species are formed during the reaction and both reactants are racemic, then the presence of homochiral or heterochiral Ti(IV) 'dimers' can be present in solution. In contrast, if both reactants are enantiopure, only homochiral 'dimers' are possible. As a consequence, it was hypothesized that different reactivities and concentrations of diastereomeric Ti(IV) 'dimers' were the cause of the observed change in the selectivities of the reactions with racemic vs. enantiopure 177. That is, the formation of the putative homochiral Ti(IV) 'dimers' would become increasingly favored as the enolate used was increasingly enantioenriched. If the reaction of the putative homochiral Ti 'dimer' was less selective than that of the heterochiral 'dimer' and if the formation of the heterochiral 'dimer' was thermodynamically favored, then the results observed in Table 2.3 , entries $1-7$, could be rationalized.

\footnotetext{
${ }_{\text {*** }}$ Reactions performed by Mohammad M. Zahedi.
} 
Table 2.3 Aldol reactions of $( \pm)-\mathbf{1 7 3}$ with $\mathrm{TiCl}\left(\mathrm{O}^{i} \mathrm{Pr}\right)_{2}$ enolate 177 .

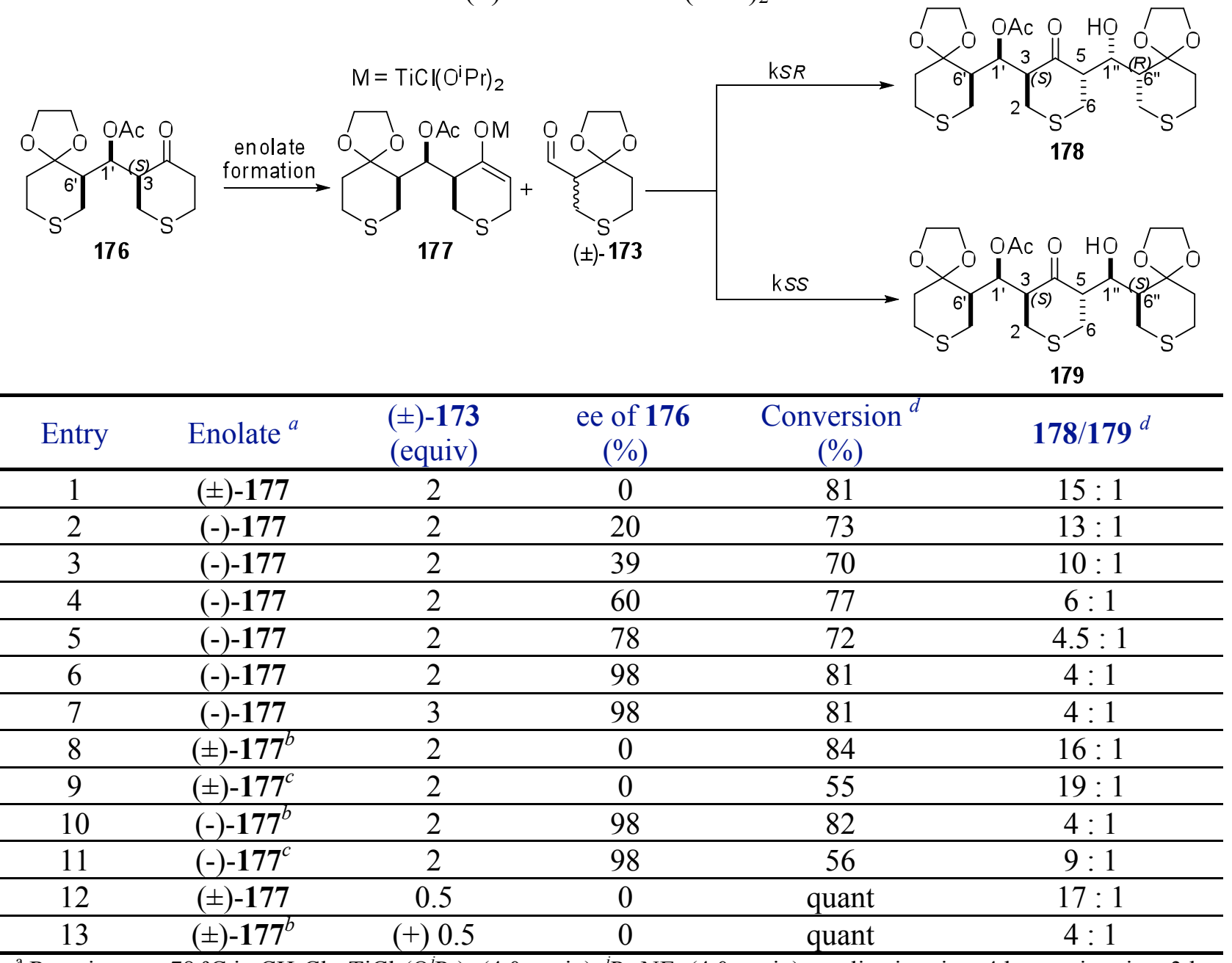

${ }^{a}$ Reactions at $-78^{\circ} \mathrm{C}$ in $\mathrm{CH}_{2} \mathrm{Cl}_{2}, \mathrm{TiCl}_{2}\left(\mathrm{O}^{i} \mathrm{Pr}\right)_{2}$ (4.0 equiv), ${ }^{i} \mathrm{Pr}_{2} \mathrm{NEt}$ (4.0 equiv), enolization time $4 \mathrm{~h}$, reaction time $3 \mathrm{~h}$, reaction concentration $0.06 \mathrm{M} .{ }^{\mathrm{b}}$ Reaction concentration $0.1 \mathrm{M} .{ }^{\mathrm{c}}$ Reaction concentration $0.02 \mathrm{M} .{ }^{\mathrm{d}}$ Conversions and 178/179 ratios were determined by ${ }^{1} \mathrm{H}-\mathrm{NMR}$ from the crude sample.

Interestingly, when the reaction was performed at lower concentrations, the selectivity slightly improved (Table 2.3, entries 1 and 9). Because lower concentrations should reduce proportion of Ti(IV) 'dimers', this observation implied that the reaction of monomeric species was more selective than that of 'dimers.' Consistent with that observation, when the reactions of enantioenriched enolate were conducted at lower concentration, the selectivity increased markedly (Table 2.3, entries 6 and 11).

Surprisingly, performing the aldol reaction between racemic enolate $\mathbf{1 7 7}$ and a deficiency of enantioenriched aldehyde $\mathbf{1 7 3}$ also showed poor selectivity (Table 2.3, entries 12 and 13). The 
observed result indicates that the enantiopurity of the aldehyde was also contributing to the nonlinear behavior. Thus, it seems that a more complex system perhaps involving coordination of aldehyde 173 to a dimeric species of the Ti(IV) enolate of 177 was involved.

In conclusion, the nonlinear effect in the selectivity was characterized using two different substrates. Apparently, both ketone 176 and aldehyde 173 contributed to the selectivity in the reaction, and as a consequence, the relative facility of the like vs. unlike combination of reactant enantiomers (i.e., $k_{\mathrm{SR}} / k_{\mathrm{SS}}$ ) is dependent on the ee of both reactants, this observation appears to be unprecedented.

\subsubsection{Study of the selectivity in the aldol reactions between 3-pentanone and racemic 2-(6- ethyl-3,5-dimethyl-4-oxo-4H-pyran-2-yl)propanal}

The racemic aldehyde bearing the $\gamma$-pyrone fragment (30) was successfully elaborated from propionic acid using the conditions of Mullock and Suschitzky to generate the $\gamma$-pyrone 96. ${ }^{43}$ Subsequently, an aldol-type reaction of paraformaldehyde with the anion generated by treatment of 96 with NaHMDS afforded alcohol $\mathbf{1 8 0},{ }^{42}$ that was oxidized with IBX to produce the desired racemic aldehyde $\mathbf{3 0}$ in quantitative yield. ${ }^{\dagger \dagger}$

Scheme 2.17 Preparation of aldehyde ( \pm )-30.

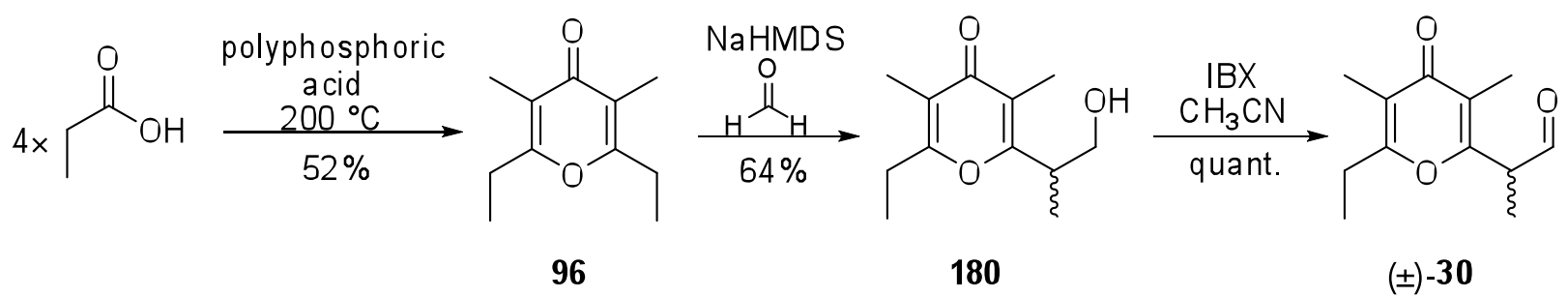

To establish the diastereoface selectivity of aldehyde 30, various aldol reactions were performed with 3-pentanone (Table 2.4). Reaction of the LiHMDS-generated Li enolate of 3pentanone $^{64}$ with $( \pm)-\mathbf{3 0}$, produced a mixture of $181(39 \%), \mathbf{1 8 2}(9 \%)$, and $183(10 \%)$; i.e., $83 \%$

\footnotetext{
${ }^{{ }^{\dagger \dagger}}$ The procedure for preparation of aldehyde $( \pm)$-30 was studied and developed by Leon Lai, unpublished results.
} 
of products resulted from Felkin addition to 30. Similar reaction of the $\mathrm{Sn}$ (II) enolate of 3pentanone (prepared by reaction with $\mathrm{Sn}(\mathrm{OTf})_{2} / \mathrm{Et}_{3} \mathrm{~N},{ }^{65}$ known to produce $Z$ enolates) with $( \pm)$ $\mathbf{3 0}$ gave the Felkin adduct $\mathbf{1 8 1}$ as the sole product. Reaction of the (E)-boron enolate of 3pentanone $\left.(c-\mathrm{Hex})_{2} \mathrm{BCl} / \mathrm{Et}_{3} \mathrm{~N}\right)^{66}$ gave a $20: 1$ mixture of the Felkin adducts $\mathbf{1 8 2}$ and 181, respectively. In contrast, reaction of the $(E)$-lithium enolate of 3-pentanone $\left(\mathrm{LiN}^{t} \mathrm{Bu}\left(\mathrm{SiMe}_{3}\right)\right)^{67}$ gave a 1.8:1 mixture of the same adducts. Despite the poorly selective relative topicity observed in the reaction, addition to the aldehyde $( \pm)-\mathbf{3 0}$ was highly Felkin selective. Finally, exchange of the $\mathrm{LiN}^{t} \mathrm{Bu}\left(\mathrm{SiMe}_{3}\right)$-produced $\mathrm{Li}$ enolate of 3-pentanone with $(c-\mathrm{Hex})_{2} \mathrm{BCl}$, in order to produce a boron enolate, ${ }^{68-70}$ followed by reaction with $( \pm)-\mathbf{3 0}$ produced a 5.9:1 mixture of $\mathbf{1 8 2}$ and $\mathbf{1 8 1}$, respectively. In contrast to the aldol reaction of the unadulterated $\mathrm{Li}$ enolate, addition of ( $c$ $\mathrm{Hex})_{2} \mathrm{BCl}$ resulted in marked improvement in stereoselectivity favoring the 4,5-anti product $\mathbf{1 8 2}$, but was less selective than the reaction of the traditionally prepared boron enolate. Again, high Felkin selectivity was observed for addition to $( \pm)-\mathbf{3 0}$. 
Table 2.4 Aldol reactions between pentanone and racemic 2-(6-ethyl-3,5-dimethyl-4oxo-4H-pyran-2-yl) propanal.

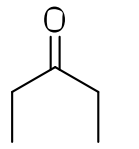

$+$<smiles>C=C1OC(CC)=C(CC)C(CC)=C1C</smiles>

$( \pm)-30$<smiles>CCC(=O)C(C)C(O)C(C)c1oc(CC)c(C)c(=O)c1C</smiles>

$( \pm)-181$<smiles>CCC(=O)[C@@H](C)[C@@H](O)C(C)c1oc(CC)c(C)c(=O)c1C</smiles>

$( \pm)-183$<smiles>CCC(=O)[C@H](C)[C@H](O)c1oc(CC)c(C)c(=O)c1C</smiles>

$( \pm)-182$<smiles>CCC(=O)C(C)[C@@H](O)[C@@H](C)c1oc(CC)c(C)c(=O)c1C</smiles>

$( \pm)-184$

\begin{tabular}{ccc}
\hline Entry & Enolate & Aldol products $^{\mathrm{f}}$ \\
\hline $1^{\mathrm{a}}$ & $\mathrm{LiHMDS}$ & $\mathbf{1 8 1}(39 \%), \mathbf{1 8 2}(9 \%), \mathbf{1 8 3}(10 \%)$ \\
\hline $2^{\mathrm{b}}$ & $\mathrm{Sn}(\mathrm{OTf})_{2}$ & $\mathbf{1 8 1}(67 \%)$ \\
\hline $3^{\mathrm{c}}$ & $(c-\mathrm{Hex})_{2} \mathrm{BCl}$ & $\mathbf{1 8 2 : 1 8 1}(20: 1), 95 \%$ conversion \\
\hline $4^{\mathrm{d}}$ & $\operatorname{LiN}^{t} \mathrm{Bu}\left(\mathrm{SiMe}_{3}\right)$ & $\mathbf{1 8 2 : 1 8 1}(1.8: 1), 90 \%$ conversion \\
\hline & i) $\left.\mathrm{LiN}^{t} \mathrm{Bu}\left(\mathrm{SiMe}_{3}\right), \mathrm{ii}\right)$ & \\
$5^{\mathrm{e}}$ & $(c-\mathrm{Hex})_{2} \mathrm{BCl}$ & $\mathbf{1 8 2 : 1 8 1}(5.9: 1), 91 \%$ conversion \\
\hline
\end{tabular}

a 3-pentanone (0.480 mmol, 2 equiv), ( \pm )-30 (0.240 mmol, 1 equiv), LiHMDS (0.504 mmol, 2.1 equiv), at $-78^{\circ} \mathrm{C}$ in THF for $30 \mathrm{~min}$. Isolated yield after FCC. ${ }^{\mathbf{b}} 3$-pentanone $(0.692 \mathrm{mmol}, 3$ equiv), ( \pm )-30 $(0.230 \mathrm{mmol}, 1$ equiv), $\mathrm{Sn}(\mathrm{OTf})_{2}\left(0.899 \mathrm{mmol}, 3.9\right.$ equiv), $\mathrm{Et}_{3} \mathrm{~N}\left(1.037 \mathrm{mmol}, 4.5\right.$ equiv) at $-78{ }^{\circ} \mathrm{C}^{\text {in }} \mathrm{CH}_{2} \mathrm{Cl}_{2}$. Enolate formation $30 \mathrm{~min}$ and aldol reaction for $2 \mathrm{~h}$. Isolated yield after $\mathrm{FCC}{ }^{\mathbf{c}} 3$-pentanone $(0.120 \mathrm{mmol}, 1$ equiv), ( \pm )-30 $(0.120 \mathrm{mmol}, 1$ equiv), $(c-\mathrm{Hex})_{2} \mathrm{BCl}\left(0.132 \mathrm{mmol}, 1.1\right.$ equiv), $\mathrm{Et}_{3} \mathrm{~N}\left(0.144 \mathrm{mmol}, 1.2\right.$ equiv), enolate formation at $0{ }^{\circ} \mathrm{C}$ for $1 \mathrm{~h}$ and aldol reaction at $-50{ }^{\circ} \mathrm{C}$ for $3 \mathrm{~h}$ in ethyl ether. Conversion calculated from ${ }^{1} \mathrm{H}-\mathrm{NMR}$ of the crude. ${ }^{\mathrm{d}} 3$-pentanone $(0.120$ mmol, 1 equiv), $( \pm)-\mathbf{3 0}\left(0.120 \mathrm{mmol}, 1\right.$ equiv), $\mathrm{LiN}^{\dagger} \mathrm{Bu}\left(\mathrm{SiMe}_{3}\right)\left(0.132 \mathrm{mmol}, 1.1\right.$ equiv) at $-78{ }^{\circ} \mathrm{C}$ in $\mathrm{THF}$. Enolate formation $30 \mathrm{~min}$ and aldol reaction $5 \mathrm{~min}$. Conversion calculated from ${ }^{1} \mathrm{H}-\mathrm{NMR}$ of the crude. ${ }^{\mathrm{e}}$ Same amounts as in entry 4. Li enolate formation $15 \mathrm{~min}$ and then $(c-\mathrm{Hex})_{2} \mathrm{BCl}\left(0.120 \mathrm{mmol}, 1\right.$ equiv) for $15 \mathrm{~min} .{ }^{\mathrm{f}}$ The set of aldol adducts $\mathbf{1 8 1}, \mathbf{1 8 2}, \mathbf{1 8 3}$, and $\mathbf{1 8 4}$ were previously synthesized and characterized by Leon Lai.

From the above studies, it was observed that the aldol reactions of 3-pentanone with aldehyde $( \pm)$-30 were highly Felkin selective under a variety of experimental conditions. Therefore, the study of enolate diastereoface selectivity for ent-95 and ent-10-epi-95 under different experimental conditions in order to produce the precursor to ent-caloundrin B (ent-3) were investigated. 


\subsubsection{Study of the stereoselectivity of aldol reactions between the enantiopure trioxaadamantane ketone fragment and the racemic pyrone aldehyde fragment}

Having in mind that aldehyde $( \pm)-\mathbf{3 0}$ is highly Felkin selective, aldol reactions of $( \pm)$-30 with ketones ent-95 and ent-10-epi-95 can produce up to four adducts with Felkin selectivity (Scheme 2.18).

Scheme 2.18 Possible products from the aldol reaction of ent-10-epi-95 and ( \pm )-30, assuming that Felkin aldehyde diastereoface selectivity is favored.

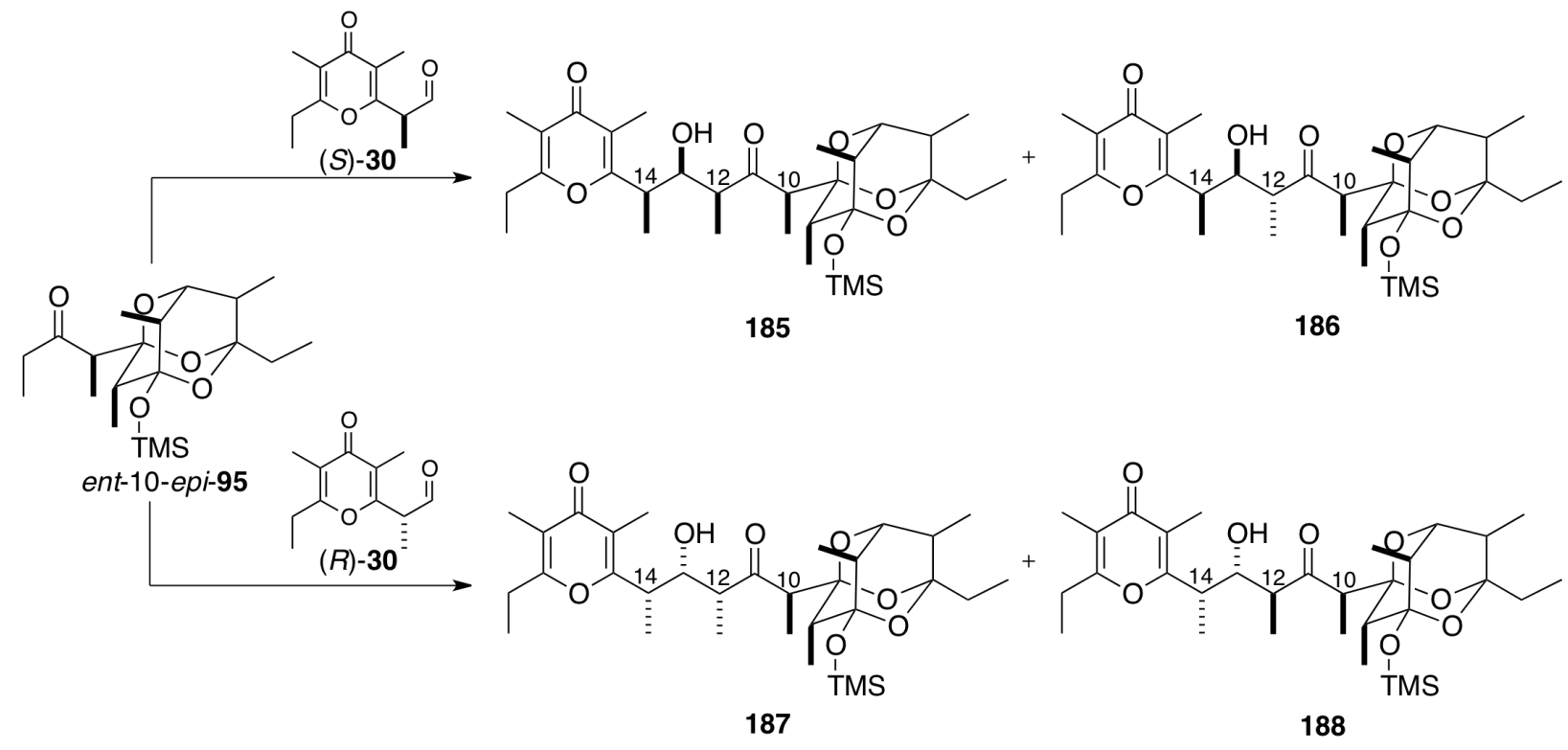

As was observed in the aldol reaction of $( \pm)$-30 with 3-pentanone, the aldol reaction of the LiHMDS-generated Li enolate of ent-10-epi-95 with ( \pm )-30 exhibited poor stereoselectivity producing a mixture of four diastereomers in a 1.3:1.3:0.8:1 ratio as determined by ${ }^{1} \mathrm{H}-\mathrm{NMR}$ of the crude reaction mixture. In contrast, addition of $( \pm)-\mathbf{3 0}$ to the putative $(Z)$-boron enolate prepared from reaction of ent-10-epi-95 with 9-BBN-OTf and $\mathrm{Et}_{3} \mathrm{~N}^{66,71}$ gave a 7:1 mixture of two aldol adducts. The major adduct, $\mathbf{1 8 5}$, was isolated in $74 \%$ yield. Reduction of $\mathbf{1 8 5}$ with $\mathrm{NaBH}(\mathrm{OAc})_{3}{ }^{72}$ afforded $78 \%$ yield of crystalline diol 189. X-ray analysis of diol 189 established the indicated relative configuration of the molecule. 

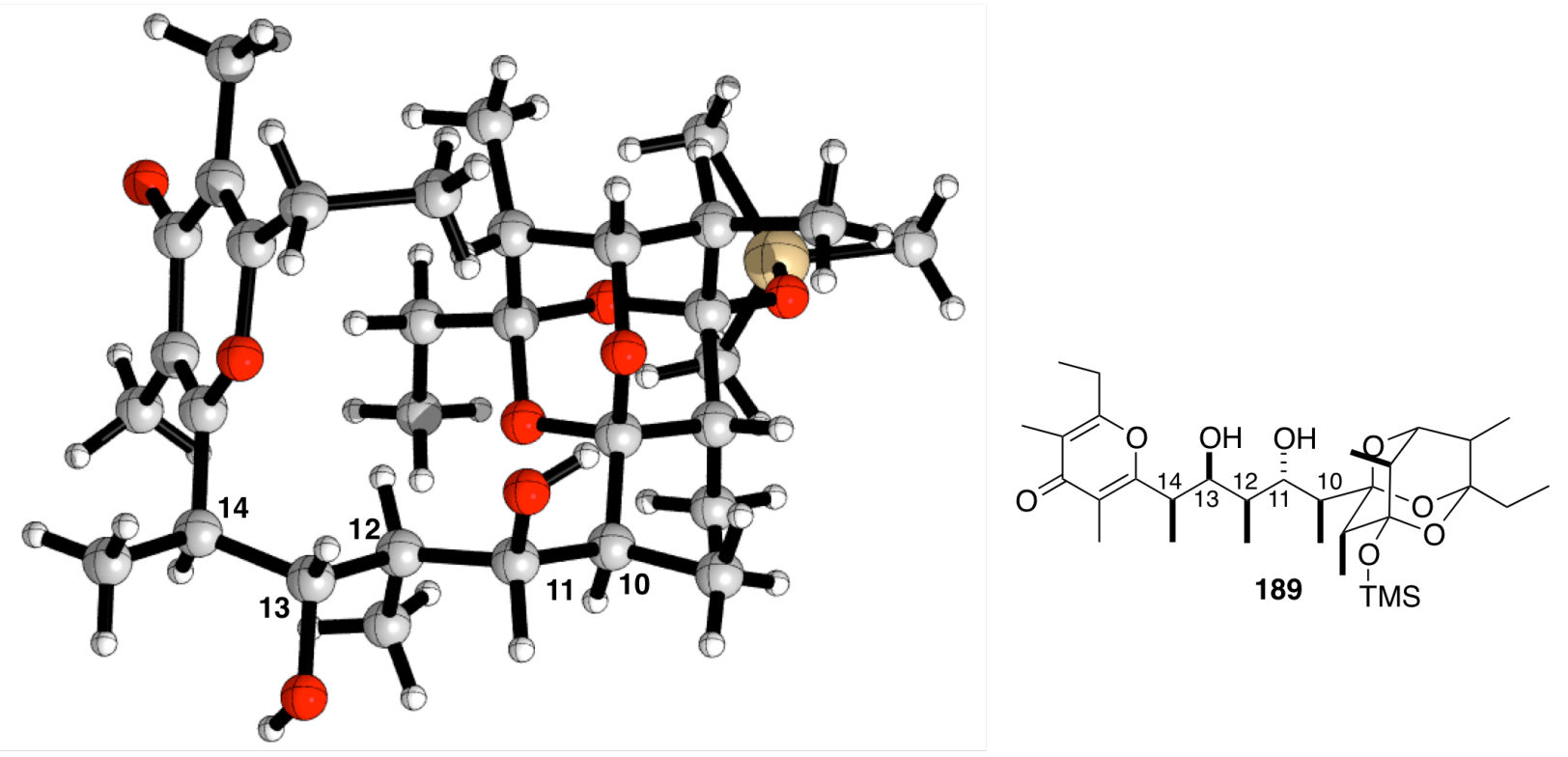

Figure 2.6 ORTEP representation for $\mathbf{1 8 9}$.

The structure of 189 shows that the initial aldol reaction of ent-10-epi-95 with $( \pm)-\mathbf{3 0}$ proceeded predominantly with 12,13-syn relative topicity, Felkin aldehyde diastereoface selectivity (13,14-syn), and 10,12-syn enolate diastereoface selectivity. The relative topicity of the reaction agreed with the reports in the literature for the diastereoselectivity observed from (Z)-enolates in acyclic systems. ${ }^{66}$ However, the Felkin aldehyde diastereoface selectivity observed was opposite to the generally expected results in aldol reactions of chiral Z-enolates and chiral 2-Me aldehydes (i.e. 10,12-anti-12,13-syn-13,14-anti). ${ }^{73}$ A possible explanation could be that the pyrone group in aldehyde $( \pm)-\mathbf{3 0}$ resembles that of a phenyl group, where the addition to the aldehyde occurs predominantly at the Felkin face.

In addition, the ${ }^{13} \mathrm{C}$ chemical shifts from $\mathrm{C}-12$ to $\mathrm{C}-16$ of aldol adduct $\mathbf{1 8 5}$ were very close to those of the model aldol adduct $\mathbf{1 8 1}$ (Table 2.5 and Chart 2.2). 
Scheme 2.19 Derivatization of $\mathbf{1 8 5}$ to determine the relative configuration.

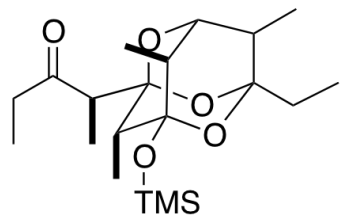

ent-10-epi-95

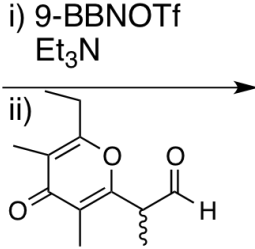

$( \pm)-30$

$74 \%$ major diastereomer

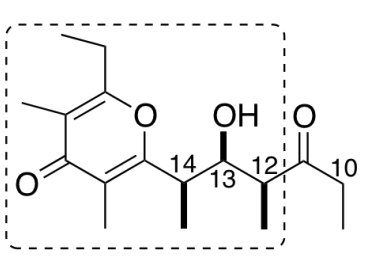

181
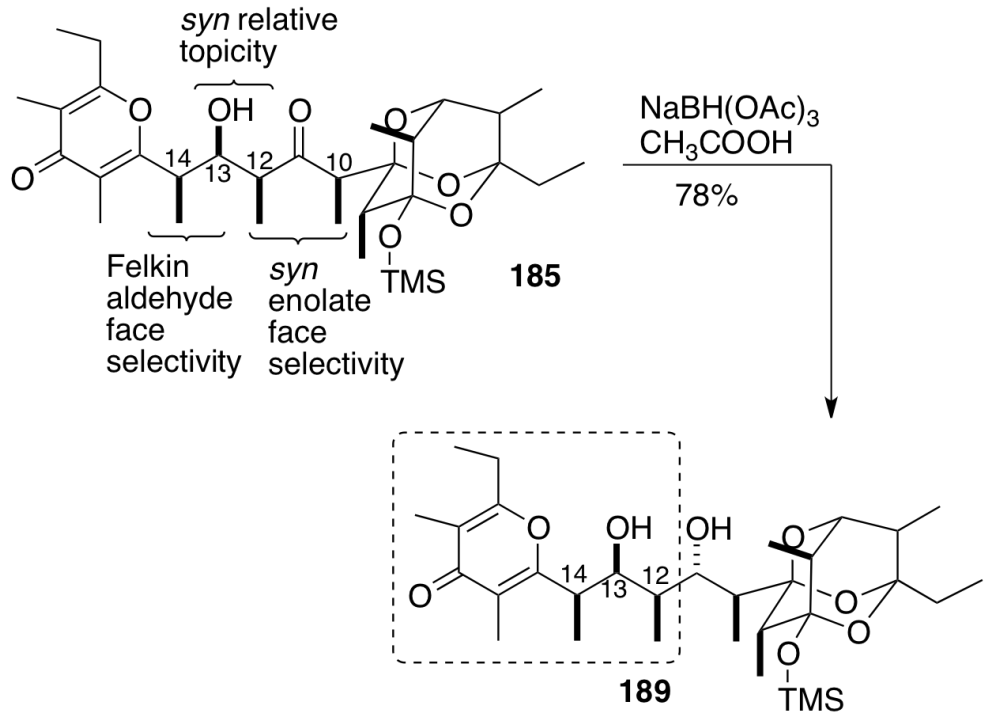

Table 2.5 Comparison of ${ }^{13} \mathrm{C}-\mathrm{NMR}$ chemical shifts of aldol adducts $\mathbf{1 8 1}, \mathbf{1 8 2}, \mathbf{1 8 3}, \mathbf{1 8 4}$, and 185 .

\begin{tabular}{lccccc}
\hline \multirow{2}{*}{ Assignment } & $\mathbf{1 8 3}$ & $\mathbf{1 8 1}$ & $\mathbf{1 8 2}$ & $\mathbf{1 8 4}$ & $\mathbf{1 8 5}$ \\
& $\delta_{\mathrm{C}}(\mathrm{ppm})$ & $\delta_{\mathrm{C}}(\mathrm{ppm})$ & $\delta_{\mathrm{C}}(\mathrm{ppm})$ & $\delta_{\mathrm{C}}(\mathrm{ppm})$ & $\delta_{\mathrm{C}}(\mathrm{ppm})$ \\
\cline { 2 - 6 } & $12,13-$-syn & $12,13-$-syn & 12,13 -anti & 12,13 -anti & \\
\hline $\mathrm{C}-11$ & $21,14-$ anti & $13,14-$ syn & $13,14-$-syn & 13,14 -anti & \\
\hline $\mathbf{C - 1 2}$ & 216.3 & 216.3 & 218 & 217.3 & 215.4 \\
\hline $\mathbf{C - 1 3}$ & $\mathbf{4 6 . 8}$ & $\mathbf{4 7 . 6}$ & $\mathbf{4 7 . 0}$ & $\mathbf{4 7 . 0}$ & $\mathbf{4 8 . 6}$ \\
\hline $\mathrm{C}-14$ & $\mathbf{7 2 . 5}$ & $\mathbf{7 2 . 4}$ & $\mathbf{7 7 . 0}$ & $\mathbf{7 7 . 6}$ & $\mathbf{7 1 . 9}$ \\
\hline $\mathbf{H}_{\mathbf{3}} \mathbf{C C}-12$ & 38.2 & 38.8 & 40.5 & 40.0 & 38.4 \\
\hline $\mathbf{H}_{\mathbf{3}} \mathbf{C C}-14$ & $\mathbf{9 . 3}$ & $\mathbf{1 0 . 0}$ & $\mathbf{1 5 . 9}$ & $\mathbf{1 5 . 9}$ & $\mathbf{1 0 . 1}$ \\
\hline $\mathrm{C}-15$ & $\mathbf{1 4 . 7}$ & $\mathbf{1 5 . 7}$ & $\mathbf{1 5 . 2}$ & $\mathbf{1 5 . 5}$ & $\mathbf{1 6}$ \\
\hline $\mathbf{C}-16$ & 164.1 & 163.9 & 164.5 & 164 & 164.4 \\
\hline $\mathrm{H}_{3} \mathrm{CC}-16$ & $\mathbf{1 1 9 . 7}$ & $\mathbf{1 1 9 . 0}$ & $\mathbf{1 1 8 . 7}$ & $\mathbf{1 1 9 . 5}$ & $\mathbf{1 1 9 . 1}$ \\
\hline
\end{tabular}


Chart 2.2 Comparison of ${ }^{13} \mathrm{C}$-NMR chemical shifts of $\mathbf{1 8 5}$ with those of the model aldol adducts $(181,182,183$, and 184).

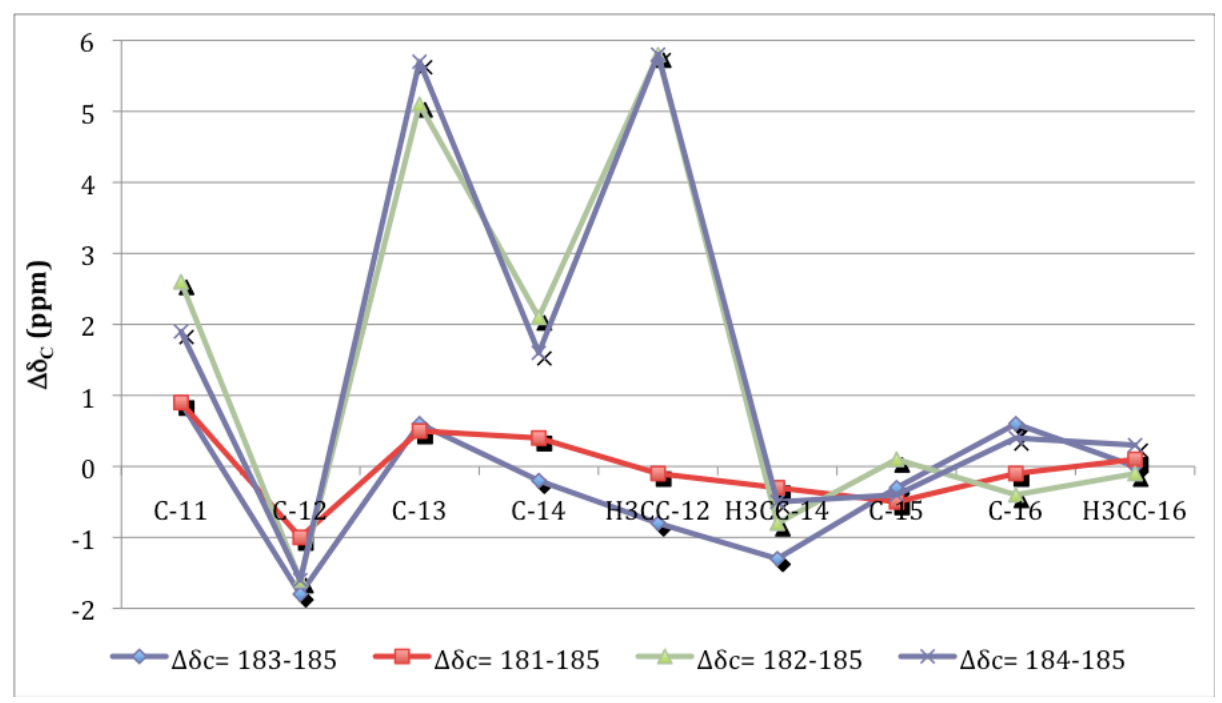

In addition, when the ${ }^{1} \mathrm{H}-\mathrm{NMR}$ chemical shifts of $\mathbf{1 8 5}$ and those of the model adducts 181, 182, 183, and 184 were compared, the characteristic signal for $\mathrm{HC}-13$ indicated that the product had a 12,13-syn selectivity and that for $\mathrm{H}_{3} \mathrm{CC}-14$ indicated that the product had a $13,14-$ syn selectivity (Table 2.6). This is, the relative topicity of the aldol reaction was 12,13 -syn and the diastereoface selectivity for addition to the aldehyde was Felkin (13,14-syn) (Table 2.6).

Table 2.6 Comparison of ${ }^{1} \mathrm{H}-\mathrm{NMR}$ chemical shifts of aldol adducts 181, 182, 183, 184 and 185 .

\begin{tabular}{|c|c|c|c|c|c|}
\hline Assignment & $\begin{array}{c}183 \\
\delta_{\mathrm{H}}(\mathrm{ppm})\end{array}$ & $\begin{array}{c}181 \\
\delta_{\mathrm{H}}(\mathrm{ppm})\end{array}$ & $\begin{array}{c}182 \\
\delta_{\mathrm{H}}(\mathrm{ppm})\end{array}$ & $\begin{array}{c}\mathbf{1 8 4} \\
\delta_{\mathrm{H}}(\mathrm{ppm})\end{array}$ & $\begin{array}{c}185 \\
\delta_{\mathrm{H}}(\mathrm{ppm})\end{array}$ \\
\hline & $\begin{array}{c}12,13-\text { syn } \\
13,14 \text {-anti }\end{array}$ & $\begin{array}{l}12,13-\text { syn } \\
13,14-\text { syn } \\
\end{array}$ & $\begin{array}{l}12,13 \text {-anti } \\
13,14-\text { syn }\end{array}$ & $\begin{array}{l}12,13 \text {-anti } \\
13,14 \text {-anti }\end{array}$ & \\
\hline $\mathrm{HC}-12$ & 2.71 & $2.37-2.28$ & $2.54-2.42$ & 2.78 & 2.92 \\
\hline HC-13 & 4.20 & 4.18 & 3.68 & 3.74 & 4.32 \\
\hline $\mathrm{HC}-14$ & 3.08 & 3.00 & 3.04 & 3.12 & 3.07 \\
\hline $\mathrm{H}_{3} \mathrm{C}-12$ & 1.22 & 1.08 & 1.22 & 1.29 & 1.14 \\
\hline $\mathrm{H}_{3} \mathrm{C}-14$ & 1.13 & 1.33 & 1.32 & 1.23 & 1.34 \\
\hline $\mathrm{H}_{3} \mathrm{C}-16$ & 1.95 & 1.96 & 1.84 & 1.97 & 1.98 \\
\hline $\mathrm{H}_{3} \mathrm{C}-18$ & 1.92 & 1.92 & 1.91 & 1.94 & 1.92 \\
\hline
\end{tabular}


Aldol reaction of $( \pm)$-30 with the putative (E)-boron enolate prepared from ent-10-epi-95 and $(c-\mathrm{Hex})_{2} \mathrm{BCl} / \mathrm{Et}_{3} \mathrm{~N}^{66}$ produced a $4: 1$ a mixture of adducts in $83 \%$ yield. Following the trends from previous results with the $(Z)$-enolate and knowing that the aldehyde $( \pm)-\mathbf{3 0}$ has a strong bias for aldol addition with Felkin selectivity, it was presumed that both products resulted from Felkin addition (13,14-syn). Because the products were derived from a $(E)$-boron enolate, presumably both products had a 12,13-anti relative configuration. Therefore, it was hypothesized that the enolate diastereoface selectivity led to a major product with 10,12-syn relative configuration and a minor compound with 10,12-anti relative configuration. Although the relative configurations for the aldol adducts were not confirmed, comparison of their ${ }^{1} \mathrm{H}-\mathrm{NMR}$ signals for $\mathrm{HC}-13$ and $\mathrm{H}_{3} \mathrm{CC}-14$ (Table 2.7) and ${ }^{13} \mathrm{C}-\mathrm{NMR}$ chemical shifts with those for the model adducts $181,182,183$, and 184 suggested that the major product was 188 and the minor product was 186 (Chart 2.3 and 2.4).

Table 2.7 Comparison of ${ }^{1} \mathrm{H}-\mathrm{NMR}$ chemical shifts of aldol aducts 181, 182, 183, 184, 186 and 188.

\begin{tabular}{lcccccc}
\hline \multirow{2}{*}{ Assignment } & $\mathbf{1 8 3}$ & $\mathbf{1 8 1}$ & $\mathbf{1 8 2}$ & $\mathbf{1 8 4}$ & $\mathbf{1 8 6}$ & $\mathbf{1 8 8}$ \\
& $\delta_{\mathrm{H}}(\mathrm{ppm})$ & $\delta_{\mathrm{H}}(\mathrm{ppm})$ & $\delta_{\mathrm{H}}(\mathrm{ppm})$ & $\delta_{\mathrm{H}}(\mathrm{ppm})$ & $\delta_{\mathrm{H}}(\mathrm{ppm})$ & $\delta_{\mathrm{H}}(\mathrm{ppm})$ \\
\cline { 2 - 8 } & 12,13 -syn & $12,13-$-syn & 12,13 -anti & 12,13 -anti & & \\
\hline $\mathrm{HC}-12$ & $13,14-$-anti & $13,14-$-syn & 13,14 -syn & 13,14 -anti & & \\
\hline $\mathrm{HC}-13$ & 2.71 & $2.37-2.28$ & $2.54-2.42$ & 2.78 & 3.04 & 3.12 \\
\hline $\mathrm{HC}-14$ & $\mathbf{4 . 2 0}$ & $\mathbf{4 . 1 8}$ & $\mathbf{3 . 6 8}$ & $\mathbf{3 . 7 4}$ & $\mathbf{3 . 8 2}$ & $\mathbf{3 . 8 3}$ \\
\hline $\mathrm{H}_{3} \mathrm{C}-\mathrm{C} 12$ & 3.08 & 3.00 & 3.04 & 3.12 & 3.38 & 2.91 \\
\hline $\mathrm{H}_{3} \mathrm{C}-\mathrm{C} 14$ & 1.22 & 1.08 & 1.22 & 1.29 & 1.28 & 1.13 \\
\hline $\mathrm{H}_{3} \mathrm{C}-16$ & $\mathbf{1 . 1 3}$ & $\mathbf{1 . 3 3}$ & $\mathbf{1 . 3 2}$ & $\mathbf{1 . 2 3}$ & $\mathbf{1 . 3 1}$ & $\mathbf{1 . 3 0}$ \\
\hline $\mathrm{H}_{3} \mathrm{C}-18$ & 1.95 & 1.96 & 1.84 & 1.97 & 1.88 & 2.02 or 1.87 \\
\hline
\end{tabular}


Chart 2.3 Comparison of ${ }^{13} \mathrm{C}-\mathrm{NMR}$ chemical shifts of $\mathbf{1 8 8}$ (major compound) with those of the model aldol adducts $(\mathbf{1 8 1}, \mathbf{1 8 2}, \mathbf{1 8 3}$, and $\mathbf{1 8 4})$.

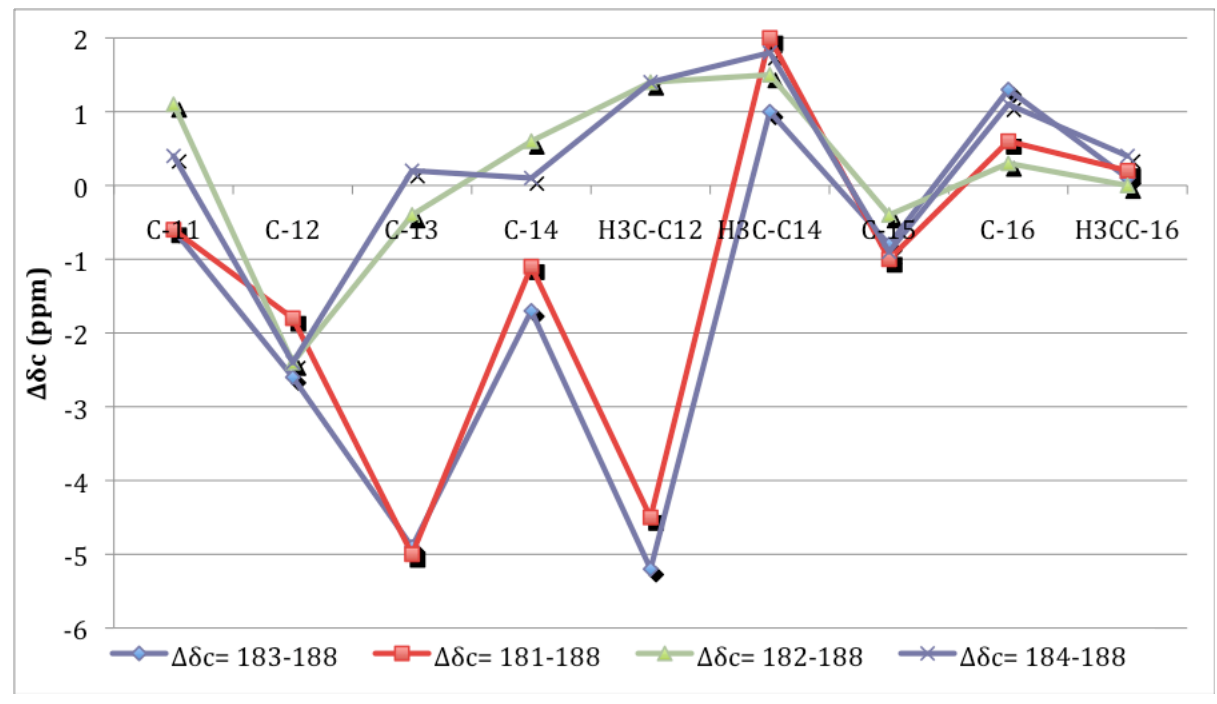

Chart 2.4 Comparison of ${ }^{13} \mathrm{C}-\mathrm{NMR}$ chemical shifts of $\mathbf{1 8 6}$ (minor compound) with those of the model aldol adducts $(\mathbf{1 8 1}, \mathbf{1 8 2}, \mathbf{1 8 3}$, and 184).

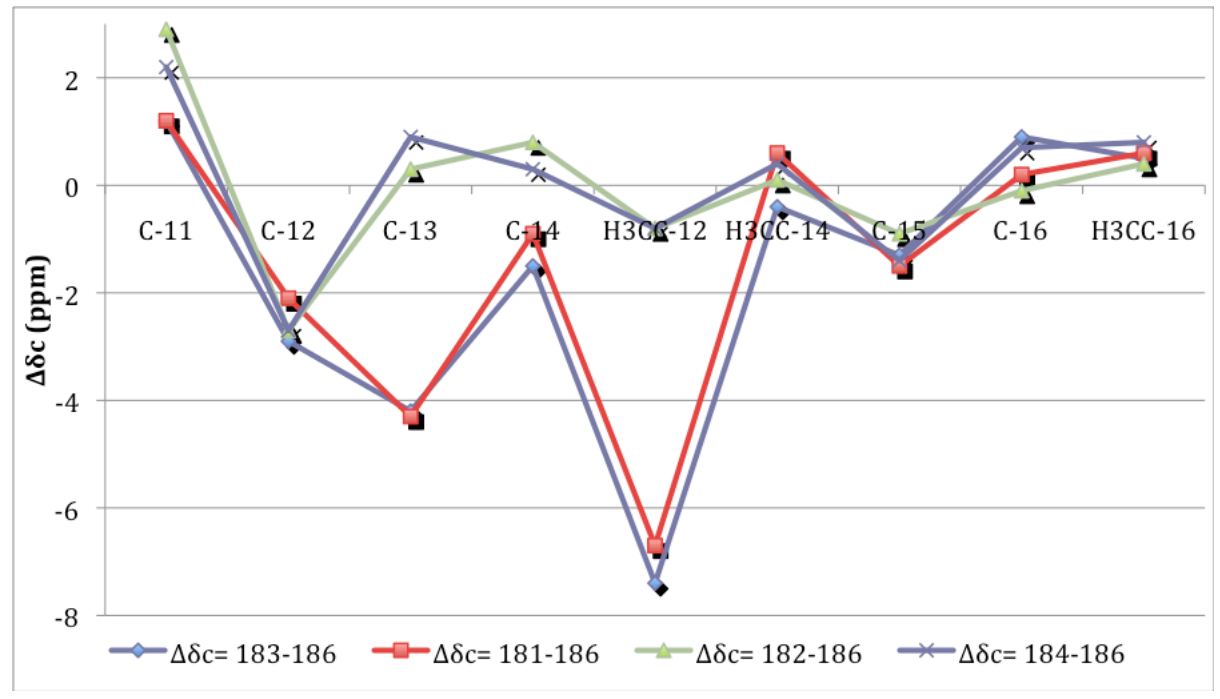

In summary, it was confirmed that the aldehyde $( \pm)$-30 had a strong preference towards Felkin selectivity in aldol reactions under the experimental conditions examined. In addition, the enolate diastereoface selectivity for both $(E)$ and $(Z)$ boron enolates of ent-10-epi-95 led 
preferentially to 10,12-syn aldol adducts and reactions with $( \pm)$-30 proceeded with kinetic resolution with moderate selectivity.

In order to synthesize ent-3, it was necessary to prepare aldol adduct 191. Compound 191 would arise from an aldol reaction between ent-95 and $(S)$-30. From the studies above, it was anticipated that aldol reactions of an $(E)$-boron enolate of ent-95 would produce adducts with 10,12-syn-12,13-anti relative configuration and that reaction with the Felkin-selective $( \pm)-30$ would proceed via kinetic resolution with preferential reaction of $(S)$-30 to give $\mathbf{1 9 1}$. However, attempted reaction of ent-95 with $(c-\mathrm{Hex})_{2} \mathrm{BCl} / \mathrm{Et}_{3} \mathrm{~N}$ followed by addition of $( \pm)$-30 gave a mixture of mainly anti aldol adducts, apparently corresponding to 191 and 193 (Scheme 2.20), in very low yield. The low conversion was attributed to ineffective formation of the boron enolate; thus, alternative conditions to produce the $(E)$-enolate of ent-95 were investigated.

Scheme 2.20 Aldol reaction of enantiopure ent-95 and ( \pm -30 assuming that Felkin aldehyde diastereoface selectivity is favored.

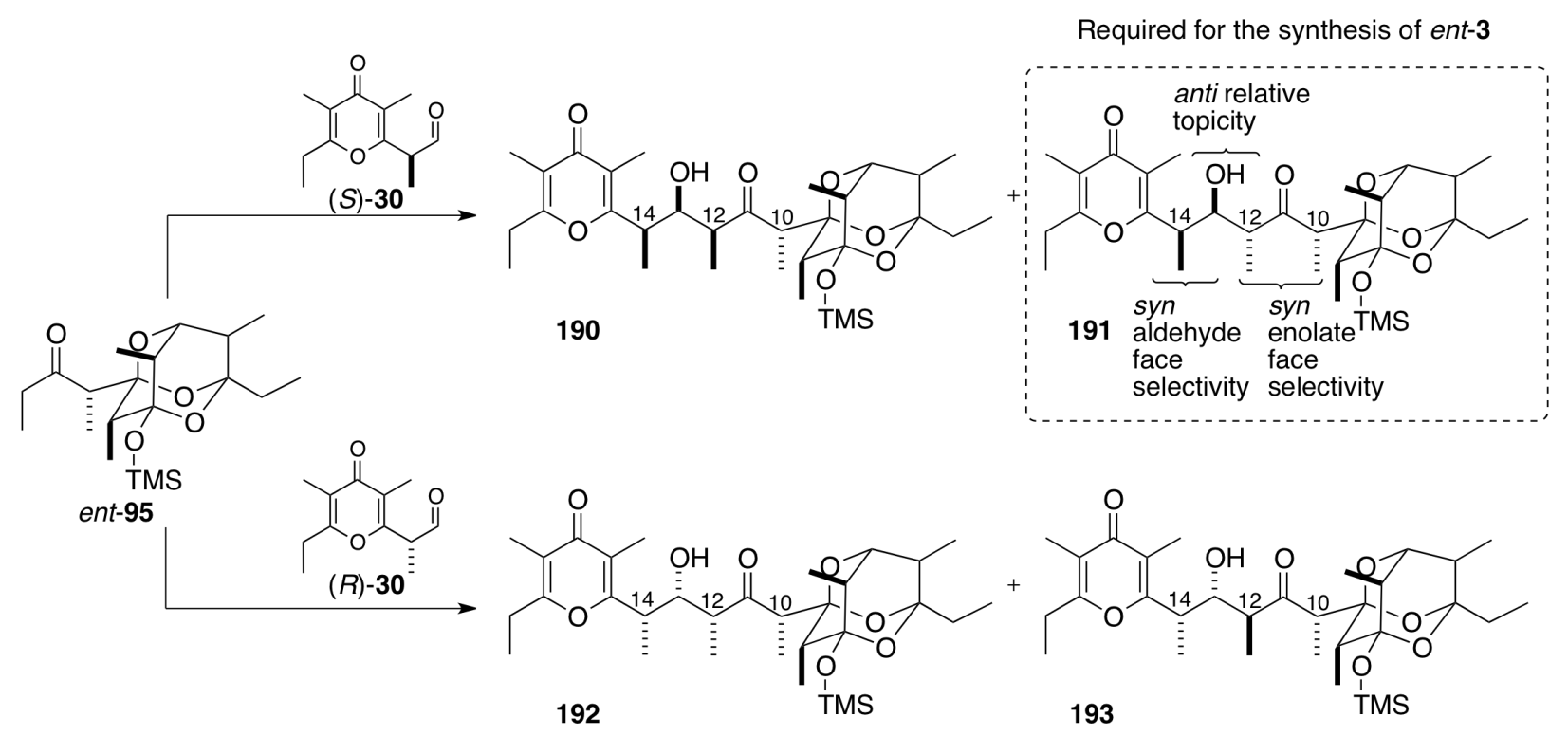

There are few reports on the stereoselective formation of $(E)$ Li-enolates. ${ }^{67,74,75}$ As previously attempted with 3-pentanone, the reaction of ent-95 with $\mathrm{LiN}^{t} \mathrm{BuSiMe}$, known to 
produce $(E)$-Li enolates from ethyl ketones, ${ }^{67}$ followed by addition of $( \pm)$-30 produced a mixture of 4 different aldol adducts. After fractionation, the two major aldol products were obtained that were tentatively assigned as 12,13-syn aldol adducts 190 and 192 by comparison of their ${ }^{1} \mathrm{H}$ and ${ }^{13} \mathrm{C}$ chemical shifts with those of the model compounds $181, \mathbf{1 8 2}, \mathbf{1 8 3}$, and 184 (Table 2.8, Chart 2.5 and 2.6).

Table 2.8 Comparison of ${ }^{1} \mathrm{H}-\mathrm{NMR}$ chemical shifts of aldol aducts 181, 182, 183, 184, 190 and 192.

\begin{tabular}{|c|c|c|c|c|c|c|}
\hline \multirow[t]{2}{*}{ Assignment } & $\begin{array}{c}183 \\
\delta_{\mathrm{H}}(\mathrm{ppm})\end{array}$ & $\begin{array}{c}181 \\
\delta_{\mathrm{H}}(\mathrm{ppm})\end{array}$ & $\begin{array}{c}\mathbf{1 8 2} \\
\delta_{\mathrm{H}}(\mathrm{ppm})\end{array}$ & $\begin{array}{c}184 \\
\delta_{\mathrm{H}}(\mathrm{ppm})\end{array}$ & $\begin{array}{c}190 \\
\delta_{H}\end{array}$ & $\begin{array}{c}192 \\
\delta_{H}\end{array}$ \\
\hline & $\begin{array}{l}12,13-\text { syn } \\
13,14-\text { anti }\end{array}$ & $\begin{array}{l}12,13-\text { syn } \\
13,14-s y n\end{array}$ & $\begin{array}{l}\text { 12,13-anti } \\
13,14-\text { syn }\end{array}$ & $\begin{array}{l}\text { 12,13-anti } \\
13,14 \text {-anti }\end{array}$ & & \\
\hline HC-12 & 2.71 & $2.37-2.28$ & $2.54-2.42$ & 2.78 & 2.78 & 2.73 \\
\hline HC-13 & 4.20 & 4.18 & 3.68 & 3.74 & 4.08 & 4.05 \\
\hline HC-14 & 3.08 & 3.00 & 3.04 & 3.12 & 3.04 & 3.03 \\
\hline $\mathrm{H}_{3} \mathrm{CC}-12$ & 1.22 & 1.08 & 1.22 & 1.29 & 1.09 & 1.07 \\
\hline $\mathrm{H}_{3} \mathrm{CC}-14$ & 1.13 & 1.33 & 1.32 & 1.23 & 1.35 & 1.34 \\
\hline $\mathrm{H}_{3} \mathrm{C}-16$ & 1.95 & 1.96 & 1.84 & 1.97 & 1.99 & 1.98 \\
\hline $\mathrm{H}_{3} \mathrm{C}-18$ & 1.92 & 1.92 & 1.91 & 1.94 & 1.95 & 1.95 \\
\hline
\end{tabular}

Chart 2.5 Comparison of ${ }^{13} \mathrm{C}$-NMR chemical shifts of 190 (minor compound) with those of the model aldol adducts $(\mathbf{1 8 1}, \mathbf{1 8 2}, \mathbf{1 8 3}$, and $\mathbf{1 8 4})$.

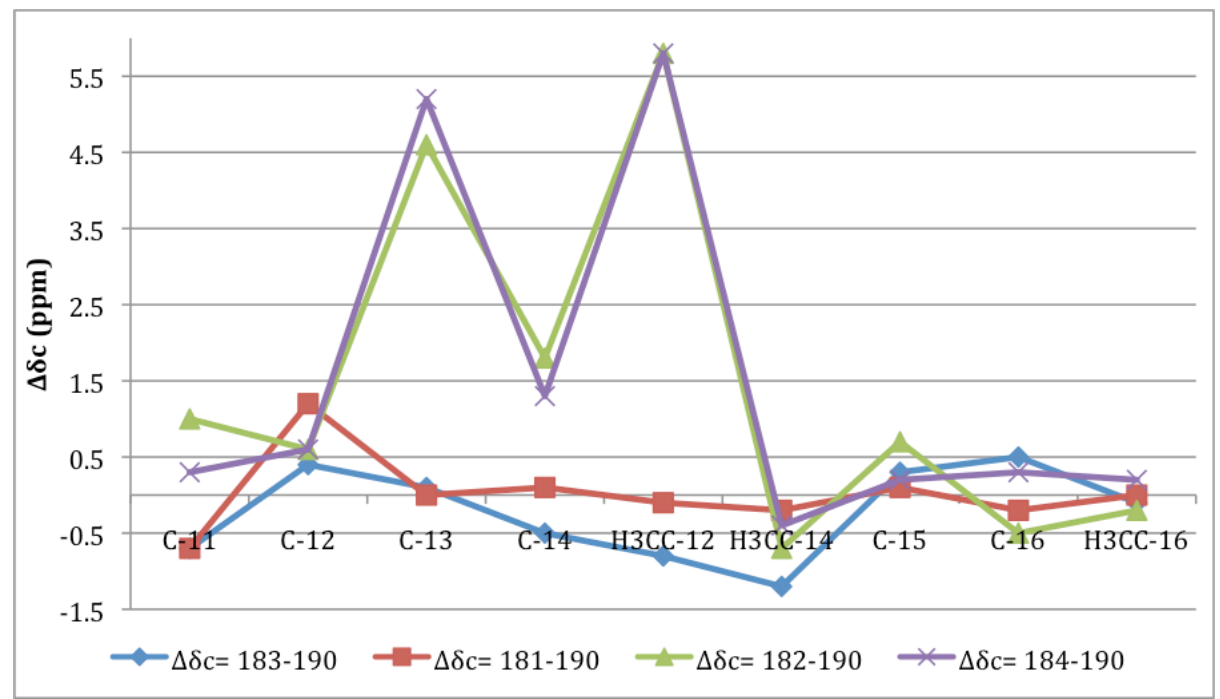


Chart 2.6 Comparison of ${ }^{13} \mathrm{C}-\mathrm{NMR}$ chemical shifts of 192 (major compound) with those of the model aldol adducts $(181,182,183$, and 184).

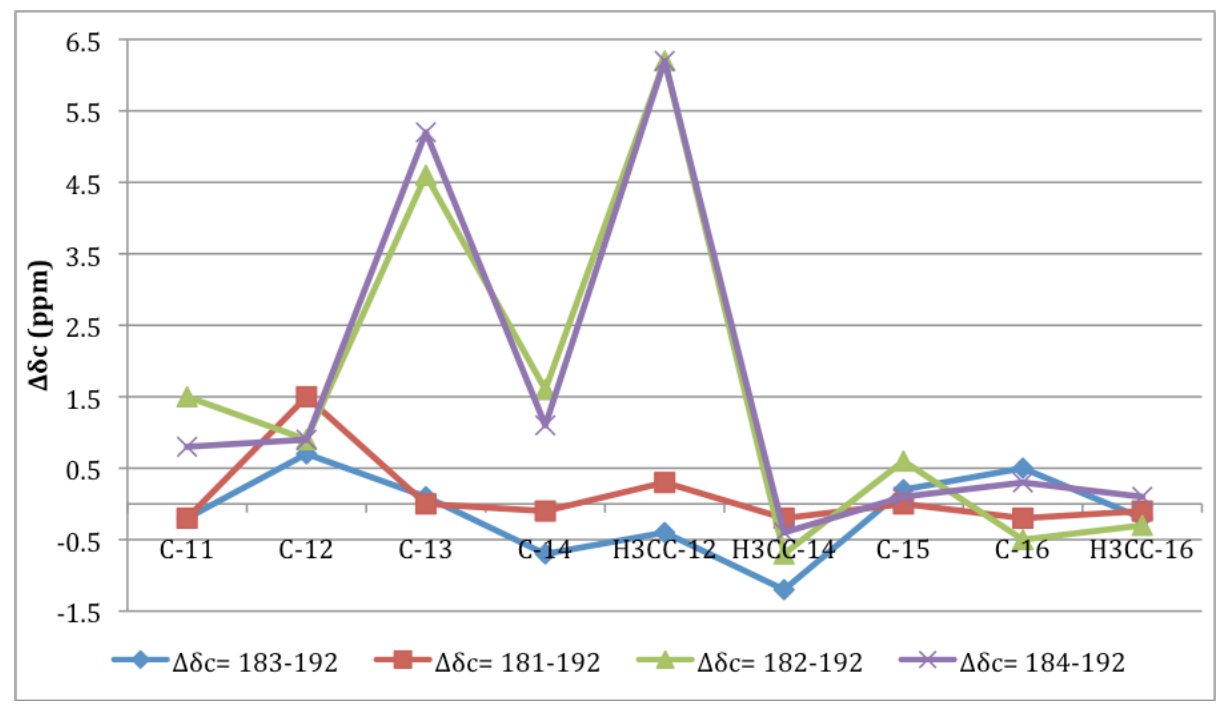

Because formation of the $(E)$-boron enolate of ent-95 was not efficient using $(c-\mathrm{Hex})_{2} \mathrm{BCl}$ $/ \mathrm{Et}_{3} \mathrm{~N}$, it was decided to attempt 'transmetallation' of $(E) \mathrm{Li}$ enolate with $(c-\mathrm{Hex})_{2} \mathrm{BCl}$. The conditions used were inspired by the early reports by Hoffmann et al. on the formation of boron enolates by transmetallation of the corresponding Li enolates. ${ }^{68,69}$

Reaction of ent-95 with $\mathrm{LiN}^{t} \mathrm{Bu}\left(\mathrm{SiMe}_{3}\right)$ followed by addition of $(c-\mathrm{Hex})_{2} \mathrm{BCl}$ and, after 75 min, addition of $( \pm)$-30 produced one major aldol adduct isolated in $60 \%$ yield along with $18 \%$ of a 2:1 mixture of other aldol adducts (Scheme 2.21). The stereoselectivity of this reaction was very different from that observed in the reaction of the $\mathrm{LiN}^{t} \mathrm{Bu}\left(\mathrm{SiMe}_{3}\right)$-generated enolate without addition of $(c \text {-Hex })_{2} \mathrm{BCl}$. The major product was tentatively assigned as 191 with 12,13anti-13,14-syn relative configuration by comparison of its ${ }^{1} \mathrm{H}$ and ${ }^{13} \mathrm{C}$ chemical shifts with those of the model compounds 181, 182, 183, and $\mathbf{1 8 4}$ (Table 2.9 and Chart 2.7). A 10,12-syn relative configuration for $\mathbf{1 9 1}$ was presumed based in literature reports on the diastereoface selectivity of (E)-enolates of chiral ethyl ketones in aldol reactions. ${ }^{76-79}$ Based on its assigned structure, aldol 191 was subjected to the transformations described in Section 2.5 towards the synthesis of ent-3. 
Scheme 2.21 Aldol reactions of ent-95 and ( \pm )-30 under different conditions.

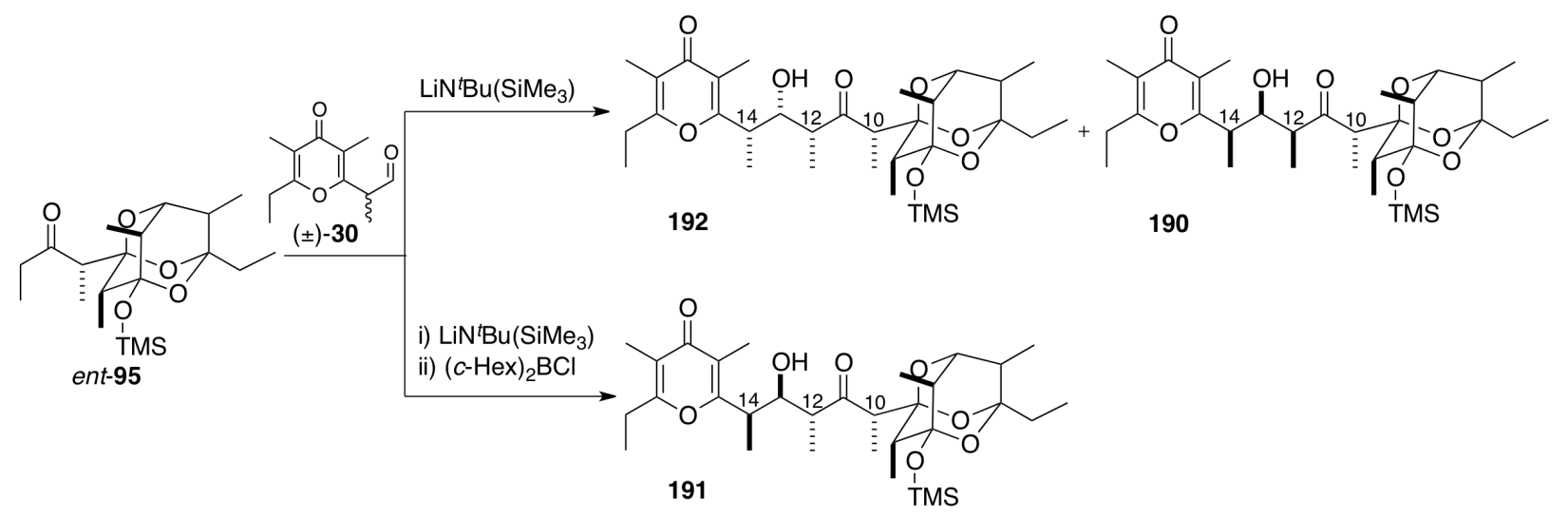

Table 2.9 Comparison of ${ }^{1} \mathrm{H}-\mathrm{NMR}$ chemical shifts of aldol aducts 181, 182, 183, 184, and 191.

\begin{tabular}{cccccc}
\hline \multirow{2}{*}{ Assignment } & $\mathbf{1 8 3}$ & $\mathbf{1 8 1}$ & $\mathbf{1 8 2}$ & $\mathbf{1 8 4}$ & $\mathbf{1 9 1}$ \\
& $\delta_{\mathrm{H}}(\mathrm{ppm})$ & $\delta_{\mathrm{H}}(\mathrm{ppm})$ & $\delta_{\mathrm{H}}(\mathrm{ppm})$ & $\delta_{\mathrm{H}}(\mathrm{ppm})$ & $\delta_{\mathrm{H}}$ \\
\cline { 2 - 6 } & 12,13 -syn & 12,13 -syn & 12,13 -anti & 12,13 -anti & \\
\hline $\mathrm{HC}-12$ & 2.71 -anti & $13,14-$-syn & $13,14-$-syn & 13,14 -anti & \\
\hline $\mathrm{HC}-13$ & $\mathbf{4 . 2 0}$ & $\mathbf{4 . 1 8}$ & $\mathbf{3 . 6 8}$ & $\mathbf{3 . 7 4}$ & $\mathbf{3 . 8 9}$ \\
\hline $\mathrm{HC}-14$ & 3.08 & 3.00 & 3.04 & 3.12 & 3.11 \\
\hline $\mathrm{H}_{3} \mathrm{C}-\mathrm{C} 12$ & 1.22 & 1.08 & 1.22 & 1.29 & 1.12 \\
\hline $\mathrm{H}_{3} \mathrm{C}-\mathrm{C} 14$ & $\mathbf{1 . 1 3}$ & $\mathbf{1 . 3 3}$ & $\mathbf{1 . 3 2}$ & $\mathbf{1 . 2 3}$ & $\mathbf{1 . 2 9}$ \\
\hline $\mathrm{H}_{3} \mathrm{C}-16$ & 1.95 & 1.96 & 1.84 & 1.97 & 1.92 or 1.93 \\
\hline $\mathrm{H}_{3} \mathrm{C}-18$ & 1.92 & 1.92 & 1.91 & 1.94 & 1.92 or 1.93 \\
\hline
\end{tabular}


Chart 2.7 Comparison of ${ }^{13} \mathrm{C}-\mathrm{NMR}$ chemical shifts of $\mathbf{1 9 1}$ (major compound) with those of the model aldol adducts $(181,182,183$, and 184).

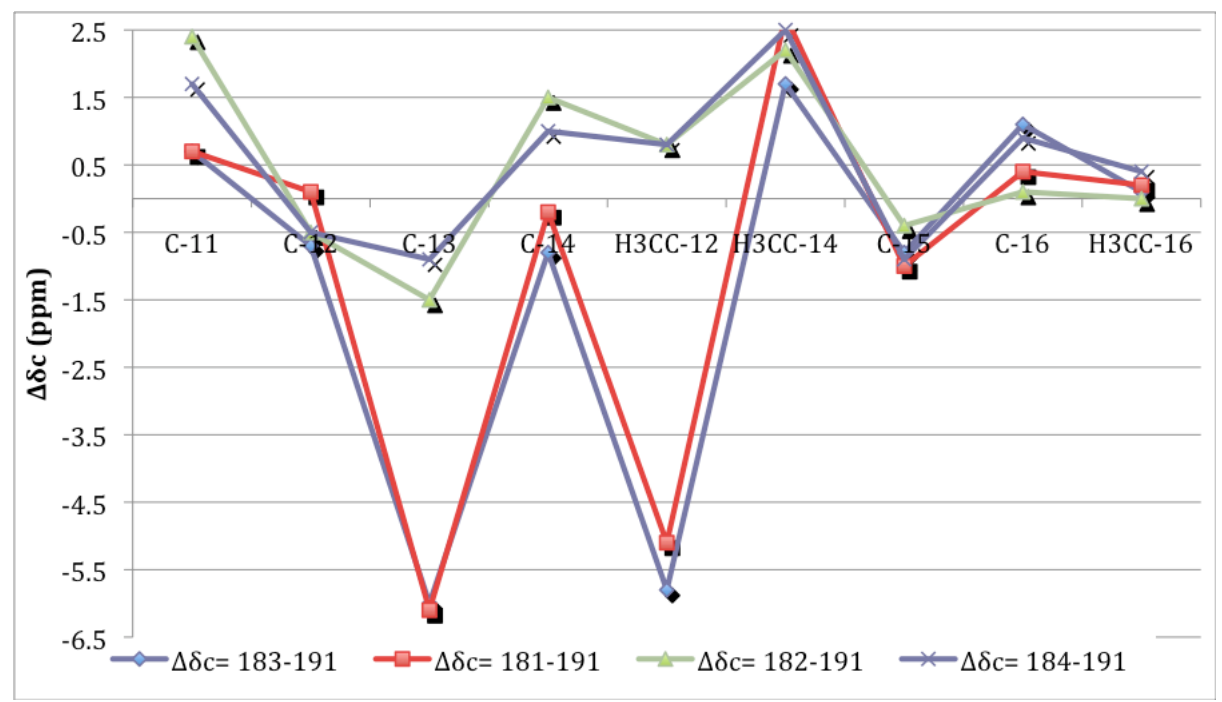

In summary, aldol reactions of ent-10-epi-95 and ent-95 with $( \pm)-30$ produced various aldol adducts under different conditions and proceeded with kinetic resolution with moderate to good enantioselectivity. It was possible to establish that additions to $( \pm)$-30 were highly Felkin selective under all conditions used. The relative topicity of the aldol reaction could be modulated by varying the enolate geometry to produce either 12,13-syn or 12,13-anti products and the enolate diastereoface selectivity preferentially gave 10,12-syn products in most cases.

\subsection{Synthesis of ent-caloundrin B (ent-3)}

With aldol adduct 191 in hand, the completion of the synthesis of ent-3 was envisaged. A 1,3-syn selective reduction of 191 was achieved by treatment with $\mathrm{Et}_{2} \mathrm{BOMe}$ and $\mathrm{NaBH}_{4}$ to afford the desired syn-diol 194 in $84 \%$ yield (Scheme 2.22). ${ }^{80}$ When compound 194 was submitted to TESOTf in the presence of 2,6-lutidine, it was observed that reaction of the $\mathrm{OH}$ group at $\mathrm{C}-11$ was faster than that at $\mathrm{C}-13$. Therefore, selective protection would be possible. However, because recycling would be complicated, the reaction was stopped at the first 
appearance of the bis-silyl ether ( $<50 \%$ conversion) to give the desired $195(31 \%)$ along with recovered 194 (61\%). IBX oxidation of 195 produced ketone 196 in excellent yield. Finally, exposure of 196 to HF-pyridine cleanly produced ent-3 $\left([\alpha]_{\mathrm{D}}+50 ; c 0.2, \mathrm{CHCl}_{3}\right)$, that gave spectroscopic data (MS, IR, ${ }^{1} \mathrm{H}$ and ${ }^{13} \mathrm{C}$ NMR) that matched perfectly with those reported ${ }^{15}$ for isolated $\mathbf{3}\left([\alpha]_{\mathrm{D}}-19 ; c 0.2, \mathrm{CHCl}_{3}\right)$ (Tables 2.10 and 2.11).

Scheme 2.22 Completion of the synthesis of ent-3.

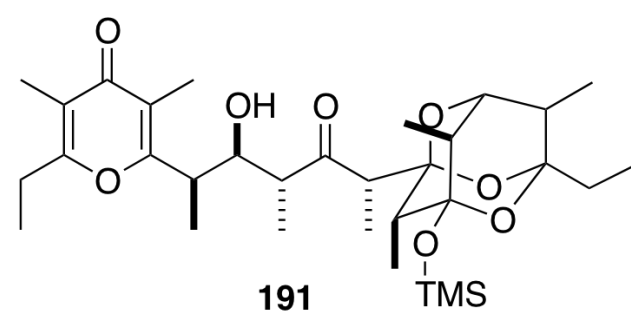

191

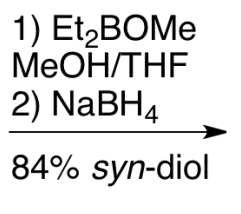

$\mathrm{MeOH} / \mathrm{THF}$ $\underset{84 \% \text { syn-diol }}{\mathrm{NaBH}_{4}}$

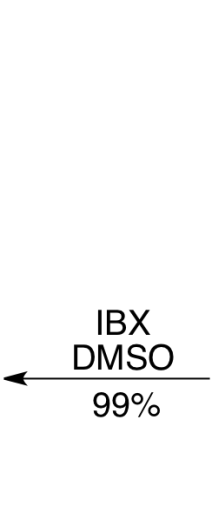

196

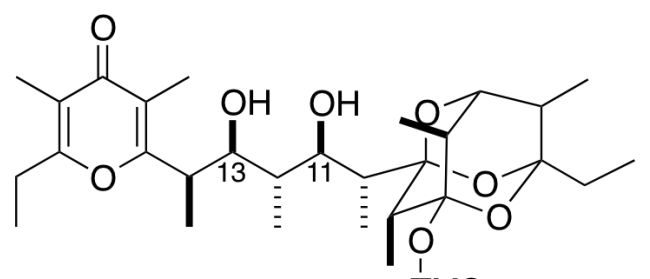

194 TMS

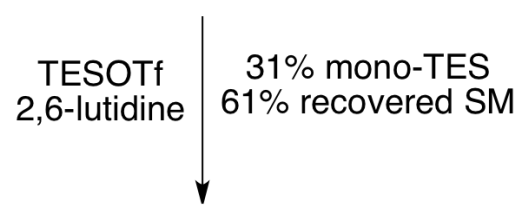

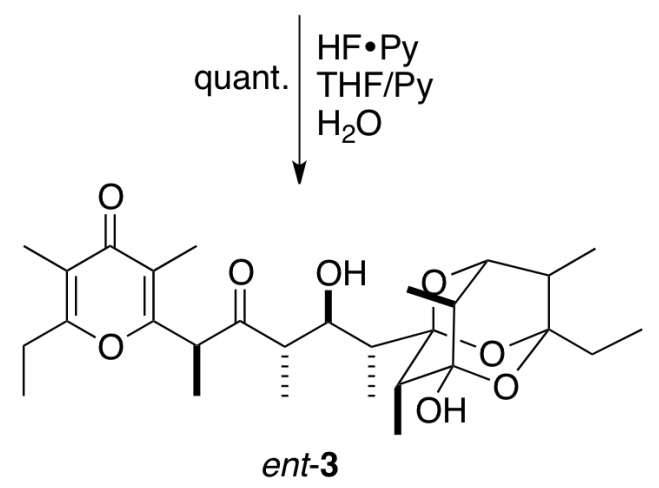


Table 2.10 Comparison of ${ }^{1} \mathrm{H}-\mathrm{NMR}$ spectra $\left(\mathrm{CDCl}_{3}\right)$ of natural 3 and synthetic ent-3.

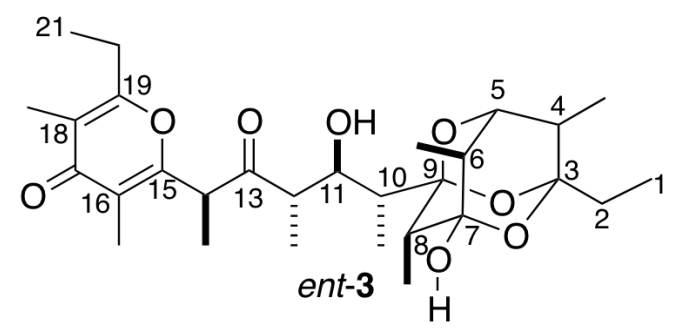

\begin{tabular}{|c|c|c|c|c|c|c|}
\hline & $\begin{array}{c}\text { Natural }^{a} \\
\text { aloundrin B (3) }\end{array}$ & & Assignment & & $\begin{array}{l}\text { Synthetic }^{b} \\
(\text { ent-3) }\end{array}$ & \\
\hline $\begin{array}{c}\delta_{\mathrm{H}}(\mathrm{ppm}) \\
(400 \\
\mathrm{MHz})\end{array}$ & multiplicity & $J(\mathrm{~Hz})$ & & $\begin{array}{c}\delta_{\mathrm{H}}(\mathrm{ppm}) \\
(500 \\
\mathrm{MHz})\end{array}$ & multiplicity & $J(\mathrm{~Hz})$ \\
\hline 4.13 & $\mathrm{q}$ & 7 & $\mathrm{HC}-14$ & 4.14 & $q$ & 7 \\
\hline 3.95 & $\mathrm{~d}$ & 7.9 & HOC-11 & 3.95 & $\mathrm{~d}$ & 7.5 \\
\hline 3.81 & brd & 3.5 & HC-5 & 3.83 & brd & 3.5 \\
\hline 3.67 & ddd & $\begin{array}{c}7.9,5, \\
4.7\end{array}$ & HC-11 & 3.68 & ddd & $7.5,5,5$ \\
\hline 3.01 & $\mathrm{dq}$ & 7,5 & HC-12 & 3.03 & $\mathrm{dq}$ & 7,5 \\
\hline 2.6 & br s & & HOC-7 & 2.62 & br s & \\
\hline 2.55 & $\mathrm{q}$ & 7.6 & $\mathrm{H}_{2} \mathrm{C}-20$ & $2.62-2.52$ & $\mathrm{~m}$ & \\
\hline 2.22 & $\mathrm{q}$ & 6.7 & $\mathrm{HC}-8$ & 2.24 & $q$ & 6.5 \\
\hline 2.09 & $\mathrm{dq}$ & $7,3.5$ & HC-4 & 2.10 & $\mathrm{dq}$ & $7,3.5$ \\
\hline 2.04 & $\mathrm{dq}$ & $7.6,4.7$ & HC-10 & $2.09-2.03$ & \multicolumn{2}{|c|}{$2 \mathrm{H}, \mathrm{m}$} \\
\hline 1.96 & $\mathrm{dq}$ & $7,<1$ & HC-6 & overlap & & \\
\hline 2.06 & $\mathrm{~s}$ & & $\mathrm{H}_{3} \mathrm{CC}-16$ & 2.07 & $\mathrm{~s}$ & \\
\hline 1.94 & $\mathrm{~s}$ & & $\mathrm{H}_{3} \mathrm{CC}-18$ & 1.95 & $\mathrm{~s}$ & \\
\hline 1.59 & $q$ & 7.5 & $\mathrm{H}_{2} \mathrm{C}-2$ & $1.65-1.54$ & $\mathrm{~m}$ & \\
\hline 1.36 & $\mathrm{~d}$ & 6.7 & $\mathrm{H}_{3} \mathrm{CC}-14$ & 1.38 & $\mathrm{~d}$ & 7 \\
\hline 1.15 & $\mathrm{t}$ & 7.6 & $\mathrm{H}_{3} \mathrm{CC}-21$ & 1.16 & $\mathrm{t}$ & 7.5 \\
\hline 1.08 & $\mathrm{~d}$ & 7 & $\mathrm{H}_{3} \mathrm{CC}-6$ & 1.09 & $\mathrm{~d}$ & 7 \\
\hline 1.01 & $\mathrm{~d}$ & 7 & $\mathrm{H}_{3} \mathrm{CC}-12$ & 1.03 & $\mathrm{~d}$ & 7 \\
\hline 0.98 & $\mathrm{~d}$ & 6.7 & $\mathrm{H}_{3} \mathrm{CC}-8$ & 0.99 & $\mathrm{~d}$ & 6.5 \\
\hline 0.95 & $\mathrm{~d}$ & 7 & $\mathrm{H}_{3} \mathrm{CC}-10$ & 0.97 & $\mathrm{~d}$ & 7 \\
\hline 0.91 & $\mathrm{t}$ & 7.5 & $\mathrm{H}_{3} \mathrm{C}-1$ & 0.93 & $\mathrm{t}$ & 7.5 \\
\hline 0.91 & $\mathrm{~d}$ & 7 & $\mathrm{H}_{3} \mathrm{CC}-4$ & 0.93 & $\mathrm{~d}$ & 7 \\
\hline
\end{tabular}

a Data and assignments from Garson et al. ${ }^{15 \mathrm{~b}}$ In this work it was used $\delta_{\mathrm{H}} \mathrm{CHCl}_{3}=7.26$. 
Table 2.11 Comparison of ${ }^{13} \mathrm{C}-\mathrm{NMR}$ spectra of natural 3 and synthetic ent-3.

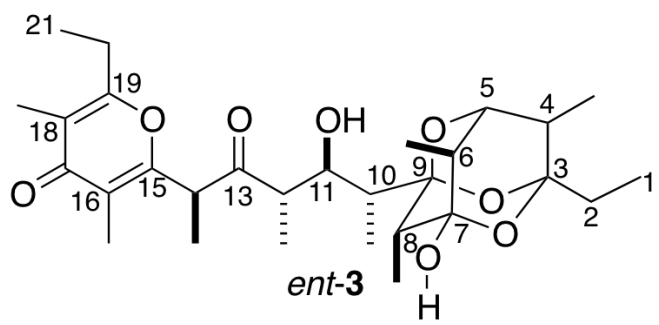

\begin{tabular}{|c|c|c|}
\hline $\begin{array}{c}\text { Natural }^{a} \\
\text { caloundrin B (3) } \delta_{\mathrm{C}}(\mathrm{ppm})\end{array}$ & Assignment $^{a}$ & $\begin{array}{c}\text { Synthetic }{ }^{b, c} \\
\left(\text { ent-3) } \delta_{C}(\mathrm{ppm})\right.\end{array}$ \\
\hline 213.1 & $\mathrm{C}-13$ & 213.4 \\
\hline 179.6 & $\mathrm{C}-17$ & 179.8 \\
\hline 164.8 & C-19 & 165.0 \\
\hline 160.1 & $\mathrm{C}-15$ & 160.3 \\
\hline 120.2 & C-16 & 120.4 \\
\hline 118.5 & C-18 & 118.7 \\
\hline 102.9 & C-9 & 103.1 \\
\hline 102.8 & $\mathrm{C}-3$ & 103.0 \\
\hline 97.2 & $\mathrm{C}-7$ & 97.4 \\
\hline 78.4 & $\mathrm{C}-5$ & 78.6 \\
\hline 77.4 & $\mathrm{C}-11$ & 77.7 \\
\hline 50.4 & $\mathrm{C}-14$ & 50.7 \\
\hline 46.2 & $\mathrm{C}-12$ & 46.5 \\
\hline 41.7 & $\mathrm{C}-10$ & 42.0 \\
\hline 36.7 & $\mathrm{C}-8$ & 36.9 \\
\hline 36.6 & $\mathrm{C}-4$ & 36.8 \\
\hline 35.6 & $\mathrm{C}-6$ & 35.8 \\
\hline 29.7 & $\mathrm{C}-2$ & 29.7 \\
\hline 24.7 & $\mathrm{C}-20$ & 24.9 \\
\hline 16.1 & $\mathrm{H}_{3} \mathrm{CC}-12$ & 16.3 \\
\hline 13.4 & $\mathrm{H}_{3} \mathrm{CC}-14$ & 13.6 \\
\hline 13.4 & $\mathrm{H}_{3} \mathrm{CC}-6$ & 13.6 \\
\hline 12.3 & $\mathrm{H}_{3} \mathrm{CC}-4$ & 12.6 \\
\hline 11.3 & $\mathrm{H}_{3} \mathrm{C}-21$ & 11.5 \\
\hline 11.2 & $\mathrm{H}_{3} \mathrm{CC}-10$ & 11.4 \\
\hline 10.1 & $\mathrm{H}_{3} \mathrm{CC}-16$ & 10.4 \\
\hline 9.5 & $\mathrm{H}_{3} \mathrm{CC}-18$ & 9.8 \\
\hline 7.5 & $\mathrm{H}_{3} \mathrm{CC}-8$ & 7.7 \\
\hline 6.3 & $\mathrm{H}_{3} \mathrm{C}-1$ & 6.5 \\
\hline
\end{tabular}


In conclusion, the first synthesis of ent-3 was achieved in 16 linear steps starting from ent102. The key steps in the synthesis involved the formation of the thermodynamically stable trioxaadamantane system ent-10-epi-116 and its transformation to ent-167 by isomerization of ent-10-epi-167. Finally, the rationally designed aldol reaction between the putative $(E)$-enolate of ent-95, formed by transmetallation of the Li enolate with $(c-\mathrm{Hex})_{2} \mathrm{BCl}$, with $( \pm)-\mathbf{3 0}$ proceeded with kinetic resolution and constituted the first synthetic application of this unusual transformation.

\subsection{Isomerization of ent-caloundrin to ent-siphonarin B}

To investigate the thermodynamic stability and possible isomerization of caloundrin B, ent-3 was treated with imidazole in $\mathrm{CDCl}_{3}$ at room temperature and the reaction was monitored by ${ }^{1} \mathrm{H}-\mathrm{NMR}$ (Figure 2.7). The rapid (reversible?) formation of an unidentified species along with the slow accumulation of ent-2 was observed. After 24 hours, the ${ }^{1} \mathrm{H}-\mathrm{NMR}$ of the crude (after work up) showed that ent-siphonarin B (ent-2) was the predominant component (ca. 50\%). Fractionation of the mixture by PTLC afforded ent-siphonarin B (ent-2) (50\%), a mixture of hemiacetal forms (22\%), along with traces of ent-3 and the unidentified new species observed above. Spectroscopic data $\left({ }^{1} \mathrm{H}\right.$ and $\left.{ }^{13} \mathrm{C}-\mathrm{NMR}\right)$ for ent-2 $\left([\alpha]_{\mathrm{D}}-50 ; c 0.1, \mathrm{CHCl}_{3}\right)$ were fully consistent with those reported ${ }^{5}$ for siphonarin $\mathrm{B}\left([\alpha]_{\mathrm{D}}+13.2 ; c 0.01361, \mathrm{CHCl}_{3}\right)$ (see Tables 2.12 and 2.13). 

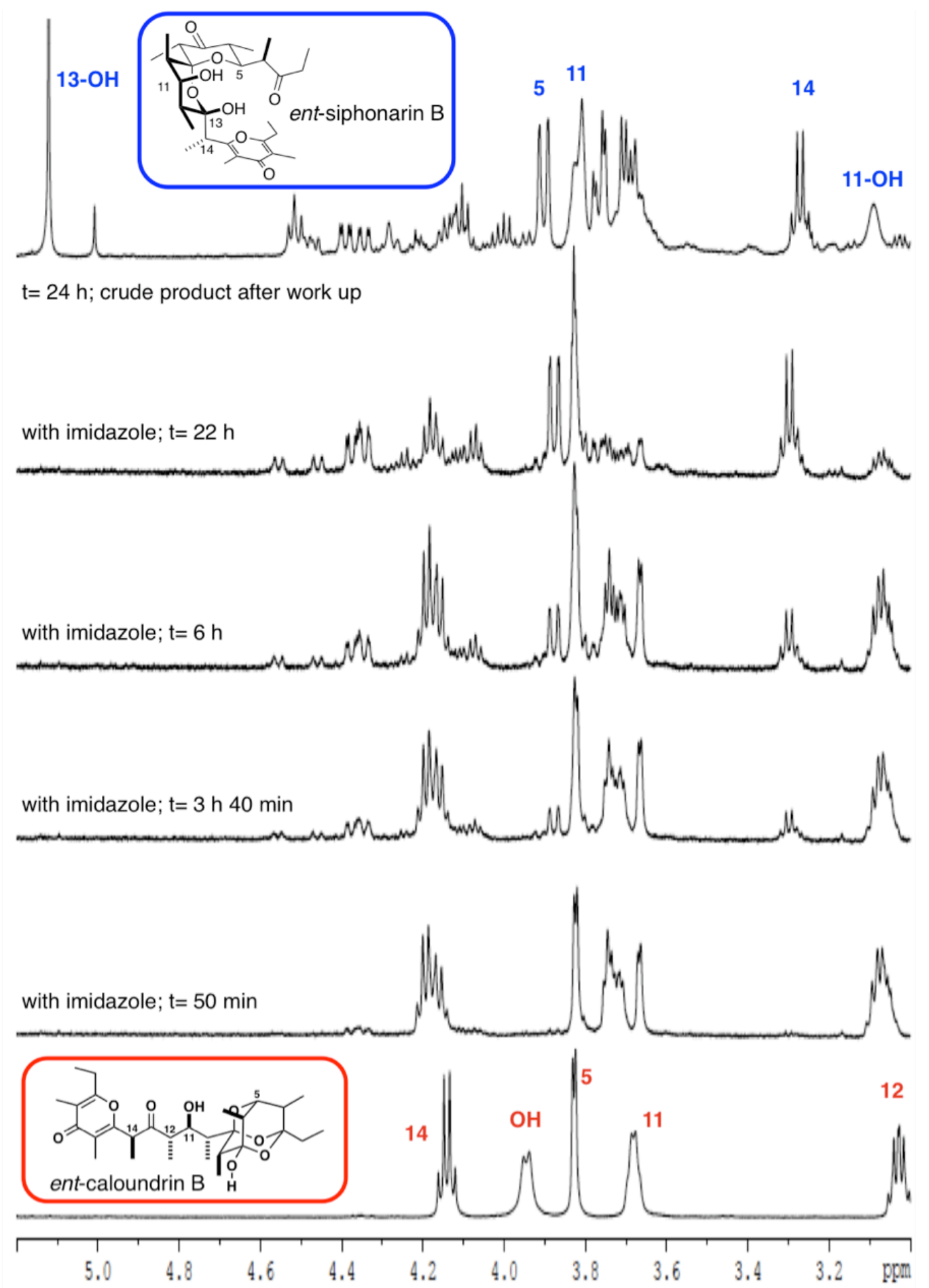

Figure 2.7 ${ }^{1} \mathrm{H}$-NMR of the isomerization of ent-3 in a solution of imidazole in $\mathrm{CDCl}_{3}$ at room temperature for 1 day. 
Table 2.12 Comparison of ${ }^{1} \mathrm{H}-\mathrm{NMR}$ spectra of natural 2 and synthetic ent-2.

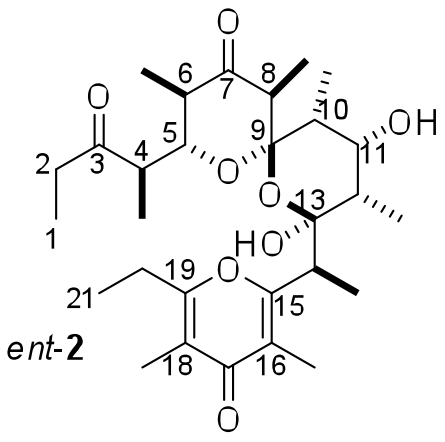

\begin{tabular}{|c|c|c|c|c|c|c|}
\hline \multicolumn{3}{|c|}{$\begin{array}{c}\text { Natural }^{a} \\
\text { siphonarin B (2) }\end{array}$} & \multirow[t]{2}{*}{ Assignment } & \multicolumn{3}{|c|}{$\begin{array}{c}\begin{array}{c}\text { Synthetic } \\
(\text { ent-2) }\end{array} \\
\end{array}$} \\
\hline $\begin{array}{c}\delta_{\mathrm{H}} \\
(\mathrm{ppm})\end{array}$ & multiplicity & $J(\mathrm{~Hz})$ & & $\begin{array}{c}\delta_{\mathrm{H}}(\mathrm{ppm}) \\
(600 \mathrm{MHz})\end{array}$ & multiplicity & $J(\mathrm{~Hz})$ \\
\hline 5.14 & $\mathrm{~S}$ & - & $\mathrm{HO}$ & 5.12 & $\mathrm{~S}$ & \\
\hline 3.88 & brd & 10.5 & HC-5 & 3.91 & $\mathrm{dd}$ & $10.5,1.5$ \\
\hline 3.81 & br s & - & $\mathrm{HC}-11$ & 3.81 & br $\mathrm{s}$ & - \\
\hline 3.28 & $q$ & 7 & $\mathrm{HC}-14$ & 3.27 & $\mathrm{q}$ & 7 \\
\hline 3.11 & br $\mathrm{s}$ & - & $\mathrm{HO}$ & 3.09 & br $\mathrm{s}$ & - \\
\hline 2.79 & $\mathrm{q}$ & 7 & $\mathrm{H}_{2} \mathrm{C}-20$ & 2.77 & ap q & 7.5 \\
\hline 2.66 & $\mathrm{q}$ & 6.5 & $\mathrm{HC}-8$ & 2.66 & $\mathrm{dq}$ & $7,1.5$ \\
\hline 2.61 & br q & 7 & $\mathrm{HC}-4$ & 2.61 & br q & 6.5 \\
\hline 2.48 & $\mathrm{dq}$ & $18.5,7$ & $\mathrm{HC}-2$ & 2.48 & $\mathrm{dq}$ & $18.5,7$ \\
\hline 2.28 & $\mathrm{dq}$ & $10.5,6.5$ & $\mathrm{HC}-6$ & $2.32-2.18$ & $2 \mathrm{H}, \mathrm{m}$ & - \\
\hline 2.25 & $\mathrm{dq}$ & $18.5,7$ & HC-2 & - & - & - \\
\hline 2.04 & $\mathrm{dq}$ & $7,2.5$ & $\mathrm{HC}-12$ & 2.05 & $\mathrm{dq}$ & $7,2.5$ \\
\hline 2.00 & $\mathrm{~s}$ & - & $\mathrm{H}_{3} \mathrm{CC}-18$ & 1.97 & $\mathrm{~s}$ & - \\
\hline 1.98 & $\mathrm{~s}$ & - & $\mathrm{H}_{3} \mathrm{CC}-16$ & 1.96 & $\mathrm{~s}$ & - \\
\hline 1.83 & $\mathrm{dq}$ & 7,2 & $\mathrm{HC}-10$ & 1.86 & $\mathrm{dq}$ & 7,2 \\
\hline 1.25 & $\mathrm{~d}$ & 7 & $\mathrm{H}_{3} \mathrm{CC}-12$ & 1.25 & $\mathrm{~d}$ & 7 \\
\hline 1.21 & $\mathrm{~d}$ & 7 & $\mathrm{H}_{3} \mathrm{CC}-10$ & 1.21 & $\mathrm{~d}$ & 7 \\
\hline 1.20 & $\mathrm{t}$ & 7 & $\mathrm{H}_{3} \mathrm{CC}-20$ & 1.21 & $\mathrm{t}$ & 7.5 \\
\hline 1.18 & $\bar{d}$ & 7 & $\mathrm{H}_{3} \mathrm{CC}-14$ & 1.18 & $\mathrm{~d}$ & 7 \\
\hline 1.07 & $\mathrm{~d}$ & 7 & $\mathrm{H}_{3} \mathrm{CC}-4$ & 1.07 & $\mathrm{~d}$ & 7 \\
\hline 1.07 & $\mathrm{~d}$ & 6.5 & $\mathrm{H}_{3} \mathrm{CC}-8$ & 1.07 & $\mathrm{~d}$ & 6.5 \\
\hline 0.94 & $\mathrm{t}$ & 7 & $\mathrm{H}_{3} \mathrm{C}-1$ & 0.94 & $\mathrm{t}$ & 7 \\
\hline 0.76 & $\mathrm{~d}$ & 6.5 & $\mathrm{H}_{3} \mathrm{CC}-6$ & 0.77 & $\bar{d}$ & 6.5 \\
\hline
\end{tabular}

${ }^{a}$ Data and assignments from Faulkner et al. ${ }^{5,15 b}$ In this work it was used $\delta_{\mathrm{H}} \mathrm{CHCl}_{3}=7.26$. 
Table 2.13 Comparison of ${ }^{13} \mathrm{C}-\mathrm{NMR}$ spectra of natural 2 and synthetic ent-2 (inverse detection at $600 \mathrm{MHz}$ ).

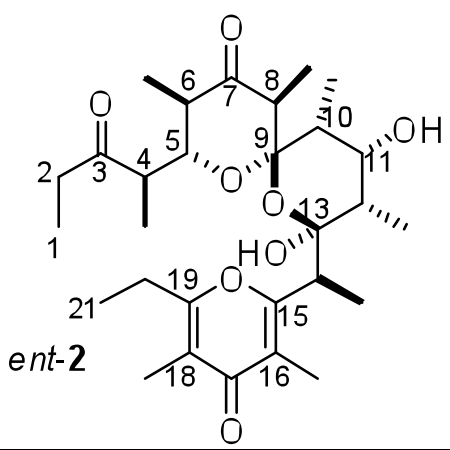

\begin{tabular}{|c|c|c|}
\hline $\begin{array}{c}\text { Natural }^{a} \text { siphonarin B (2) } \\
\delta_{\mathrm{C}}(\mathrm{ppm})\end{array}$ & Assignment $^{b}$ & $\begin{array}{c}\text { Synthetic }^{c}(\text { ent-2) } \\
\delta_{\mathrm{C}}(\mathrm{ppm})\end{array}$ \\
\hline 213.3 & $\mathrm{C}-3$ & 213.4 \\
\hline 206.4 & $\mathrm{C}-7$ & 206.5 \\
\hline 179.8 & C-17 & 179.9 \\
\hline 165.5 & C-19 & 165.6 \\
\hline 161.6 & $\mathrm{C}-15$ & 161.6 \\
\hline 121.6 & C-16 & 121.7 \\
\hline 117.2 & C-18 & 117.2 \\
\hline 105.1 & C-9 & 105.2 \\
\hline 103.1 & C-13 & 103.2 \\
\hline 74.6 & $\mathrm{C}-5$ & 74.6 \\
\hline 74.6 & C-11 & 74.6 \\
\hline 50.0 & $\mathrm{C}-8$ & 50.0 \\
\hline 46.0 & $\mathrm{C}-4$ & 46.1 \\
\hline 45.3 & $\mathrm{C}-6$ & 45.4 \\
\hline 42.4 & C-14 & 42.5 \\
\hline 38.7 & C-12 & 38.8 \\
\hline 38.4 & C-10 & 38.5 \\
\hline 35.6 & $\mathrm{C}-2$ & 35.7 \\
\hline 24.7 & $\mathrm{C}-20$ & 24.7 \\
\hline 13.0 & $\mathrm{H}_{3} \mathrm{CC}-10$ & - \\
\hline 12.6 & $\mathrm{H}_{3} \mathrm{CC}-12$ & 12.7 \\
\hline 11.9 & $\mathrm{H}_{3} \mathrm{CC}-14$ & 12 \\
\hline 11.4 & $\mathrm{H}_{3} \mathrm{CC}-20$ & 11.5 \\
\hline 10.9 & $\mathrm{H}_{3} \mathrm{CC}-16$ & 11.1 \\
\hline 9.4 & $\mathrm{H}_{3} \mathrm{CC}-18$ & 9.4 \\
\hline 9.3 & $\mathrm{H}_{3} \mathrm{CC}-6$ & - \\
\hline 8.6 & $\mathrm{H}_{3} \mathrm{CC}-8$ & 8.7 \\
\hline 8.2 & $\mathrm{H}_{3} \mathrm{CC}-4$ & - \\
\hline 7.4 & $\mathrm{H}_{3} \mathrm{C}-1$ & 7.6 \\
\hline
\end{tabular}

${ }^{\mathrm{a}}$ Data from Faulkner et al. ${ }^{4 \mathrm{~b}}$ Assignments from Garson et al. ${ }^{15 \mathrm{c}}$ There were four unresolved 'missing' signals at 8.2, 9.3, 13.0, and 74.6. 
Following the isomerization of ent-3 under the conditions used above for 5 days $10 \mathrm{~h}$ and then fractionation of the crude by PTLC produced ent-2 (33\%), ent-baconipyrone C (ent-6) (19\%), ent-14-epi-baconipyrone C (ent-14-epi-6) (16\%), and hemiacetal forms from ent-48 (ca. $20 \%)$.

To follow the isomerization process more closely, to a solution of ent-3 in $\mathrm{CH}_{3} \mathrm{CN}$ was added imidazole and the reaction followed by HPLC (Figure 2.8). Using pure samples, retention times for ent-caloundrin B (ent-3), siphonarin B (2), and the mixture of hemiacetal forms from ent-48 were established. After 2 hours, ca. 1:1 mixture of ent-3 and an unknown compound was observed and this ratio remained essentially constant over several days. After 1 day, ca. $20 \%$ of the mixture was ent-siphonarin B (ent-2) growing to ca. $70 \%$ after 6 days. The mixture was essentially unchanged after 8 days, and consisted of ent-siphonarin B (ent-2), mixture of hemiacetal forms from ent-48, and other unidentified components with no more than traces of ent-3 remaining. 


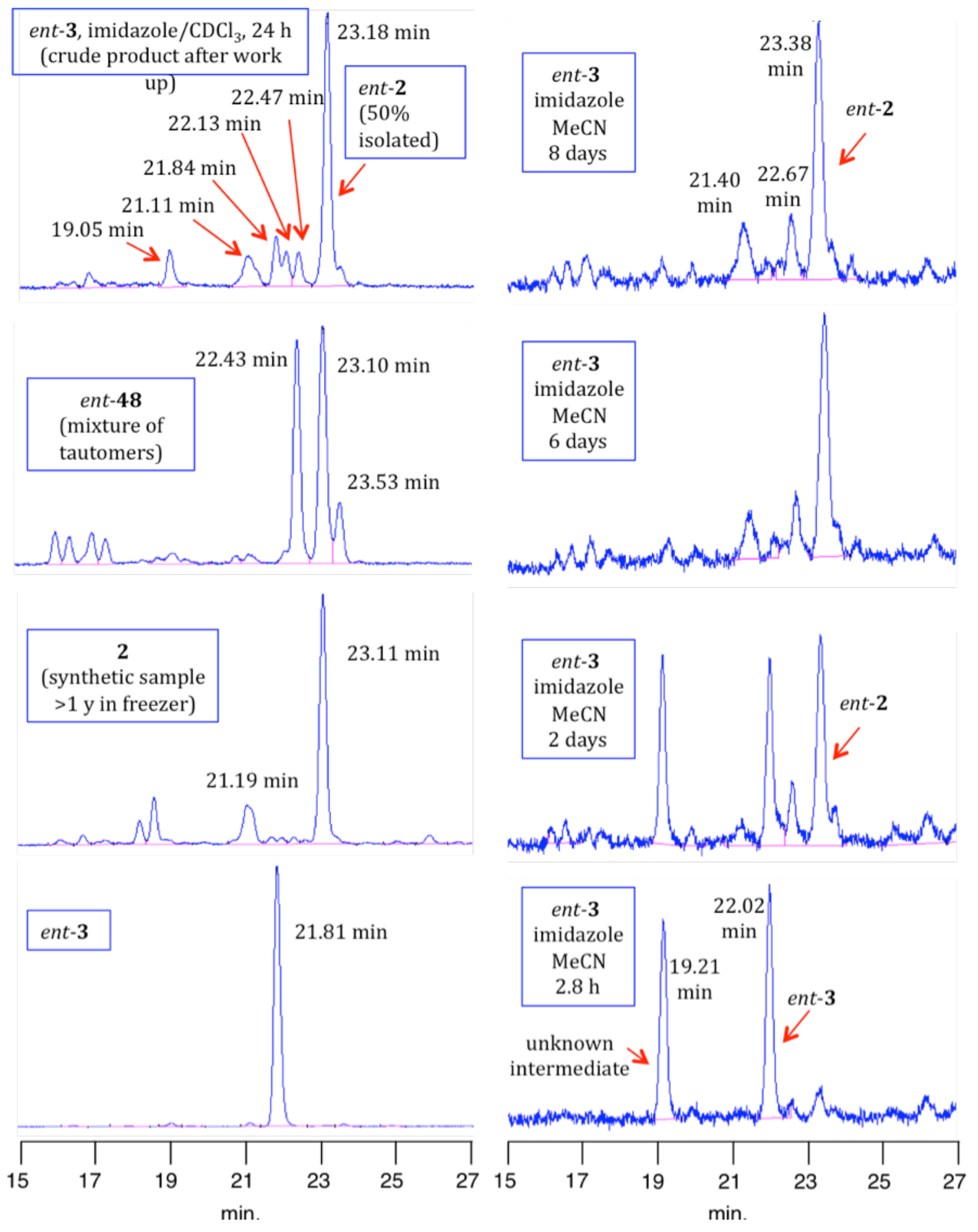

Figure 2.8 HPLC studies for the isomerization of ent-3 in a solution of imidazole in $\mathrm{CH}_{3} \mathrm{CN}$ at room temperature for 8 days. 
Monitoring the isomerization of ent-3 in the presence of imidazole both by ${ }^{1} \mathrm{H}-\mathrm{NMR}$ and HPLC indicated that the process involved a rapid equilibrium between ent-3 and an unknown intermediate. To determine the identity of this intermediate, the reaction of ent-3 with imidazole in $\mathrm{CDCl}_{3}$ was stopped after $1 \mathrm{~h}$ affording a 1.3:1 ratio of ent-3 and the unknown intermediate (by $\left.{ }^{1} \mathrm{H}-\mathrm{NMR}\right)$. Analysis of the ${ }^{13} \mathrm{C}-\mathrm{NMR}$ spectrum of the mixture clearly indicated that the unknown contained a trioxaadamantane fragment in its structure (signals at $\delta_{\mathrm{C}} 102.7,102.8$, and 97.6). Comparison of the ${ }^{13} \mathrm{C}-\mathrm{NMR}$ chemical shifts of ent-3 and the unknown revealed the same trends as a similar comparison of baconipyrone C (6) and 14-epi-baconipyrone C (14-epi-6) (Table 2.14). ${ }^{9}$ Thus, it was concluded that the unknown intermediate was most likely ent-14-epi-3. 
Table 2.14 Comparison of ${ }^{13} \mathrm{C}-\mathrm{NMR}$ spectra of ent-3, ent-14-epi-3, 6 and 14-epi-6.
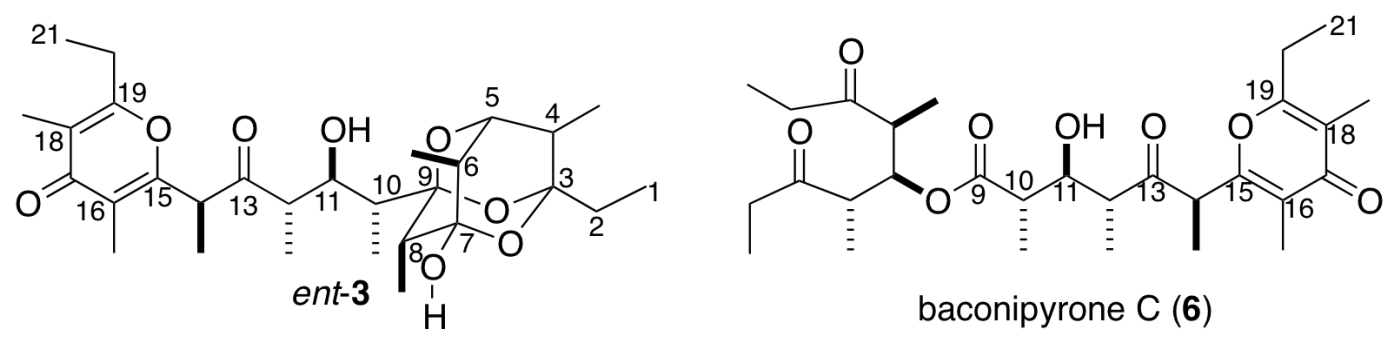

\begin{tabular}{|c|c|c|c|c|}
\hline $\begin{array}{c}\text { ent-3 } \\
\delta_{\mathrm{C}}(\mathrm{ppm})\end{array}$ & $\begin{array}{c}\text { ent-14-epi-3 } \\
\delta_{\mathrm{C}}(\mathrm{ppm})\end{array}$ & Assignment ${ }^{\mathrm{a}}$ & $\begin{array}{c}\mathbf{6}^{b} \\
\delta_{C}(\mathrm{ppm})\end{array}$ & $\begin{array}{l}14-e p i-\mathbf{6}^{b} \\
\delta_{\mathrm{C}}(\mathrm{ppm})\end{array}$ \\
\hline 6.5 & 6.5 & C-1 & & \multirow{9}{*}{$c$} \\
\hline 29.7 & 29.6 & $\mathrm{C}-2$ & & \\
\hline 103 & 102.7 & C-3 & & \\
\hline 36.8 & 36.9 & C-4 & & \\
\hline 78.6 & 78.2 & C-5 & & \\
\hline 35.8 & 35.7 & $\mathrm{C}-6$ & & \\
\hline 97.4 & 97.6 & C-7 & & \\
\hline 36.9 & 36.9 & C-8 & & \\
\hline 103.1 & 102.8 & C-9 & & \\
\hline 42.0 & 42.4 & $\mathrm{C}-10$ & 41.3 & 42.4 \\
\hline $77.7^{d}$ & $76.2^{d}$ & C-11 & 77.8 & 76.6 \\
\hline $46.5^{d}$ & $45.1^{d}$ & C-12 & 48.8 & 47.8 \\
\hline 213.4 & 213.5 & $\mathrm{C}-13$ & 210.7 & 210.6 \\
\hline $\mathbf{5 0 . 7 ^ { d }}$ & $47.5^{d}$ & C-14 & 51.2 & 48.7 \\
\hline $160.3^{d}$ & $159.7^{d}$ & C-15 & 160.8 & 160.0 \\
\hline 120.4 & 120.4 & $\mathrm{C}-16$ & 120.6 & 120.4 \\
\hline 179.8 & 179.8 & C-17 & 179.9 & 179.9 \\
\hline 118.7 & 118.6 & C-18 & 118.5 & 118.3 \\
\hline 165.0 & 165.1 & C-19 & 164.8 & 165.0 \\
\hline 24.9 & 24.9 & $\mathrm{C}-20$ & 24.9 & 25.0 \\
\hline 11.5 & 11.6 & $\mathrm{C}-21$ & 11.5 & 11.5 \\
\hline 12.6 & 12.5 & $\mathrm{H}_{3} \mathrm{CC}-4$ & \multirow{3}{*}{\multicolumn{2}{|c|}{$\mathrm{c}$}} \\
\hline 13.6 & 13.4 & $\mathrm{H}_{3} \mathrm{CC}-6$ & & \\
\hline 7.7 & 7.6 & $\mathrm{H}_{3} \mathrm{CC}-8$ & & \\
\hline 11.4 & 10.3 & $\mathrm{H}_{3} \mathrm{CC}-10$ & 15.3 & 15.1 \\
\hline 16.3 & 16.9 & $\mathrm{H}_{3} \mathrm{CC}-12$ & 14.4 & 14.9 \\
\hline 13.6 & 13.3 & $\mathrm{H}_{3} \mathrm{CC}-14$ & 13.4 & 13.5 \\
\hline 10.4 & 10.3 & $\mathrm{H}_{3} \mathrm{CC}-16$ & 10.1 & 10.0 \\
\hline 9.8 & 9.7 & $\mathrm{H}_{3} \mathrm{CC}-18$ & 9.7 & 9.7 \\
\hline
\end{tabular}

${ }^{\mathrm{b}}$ Data and assignments for 6 according to Faulkner. ${ }^{10 \mathrm{~b}}$ Taken from reference ${ }^{9 \mathrm{c}}$ Fragments from $\mathrm{C}$-to $\mathrm{C}-9$ are structurally different between ent-3 and $\mathbf{6}$, therefore those chemical shifts are not comparable. ${ }^{\mathrm{d}} \Delta \delta_{\mathrm{C}}>0.6 \mathrm{ppm}$. 
Thus, the initial transformation after exposure of ent-3 to imidazole was the epimerization at $\mathrm{C}-14$, and then ent-3 isomerized to ent-siphonarin B (ent-2). Therefore, during the isomerization process the ratio between ent-3 and ent-14-epi-3 remained constant, as observed by HPLC. However, once the equilibrium was reached, mainly ent-2 was formed in the mixture. In addition, longer reaction time in imidazole also produced ent-baconipyrone C (ent-6) and ent-14-epi-6 confirming that baconipyrones $\mathbf{4}$ and $\mathbf{6}$ correspond to artifacts from isolation.

Scheme 2.23 Study of the isomerization of ent-3 into ent-2.

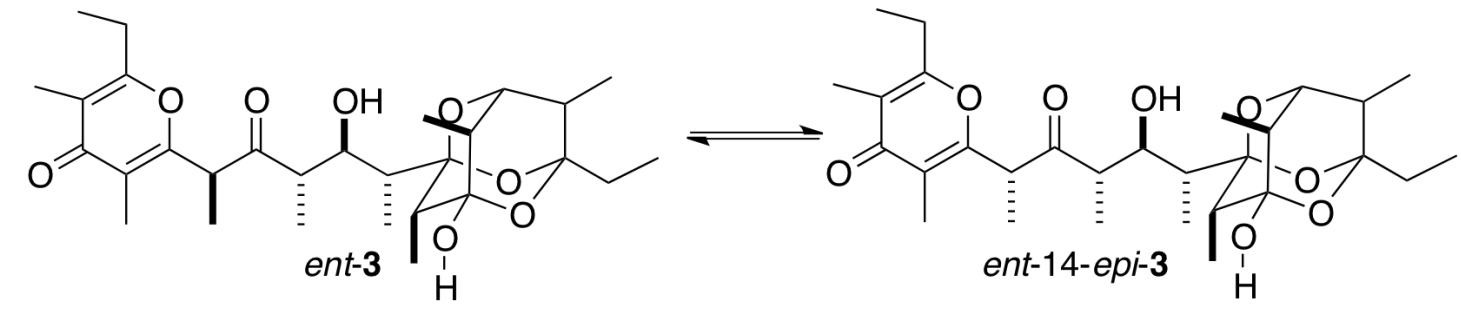

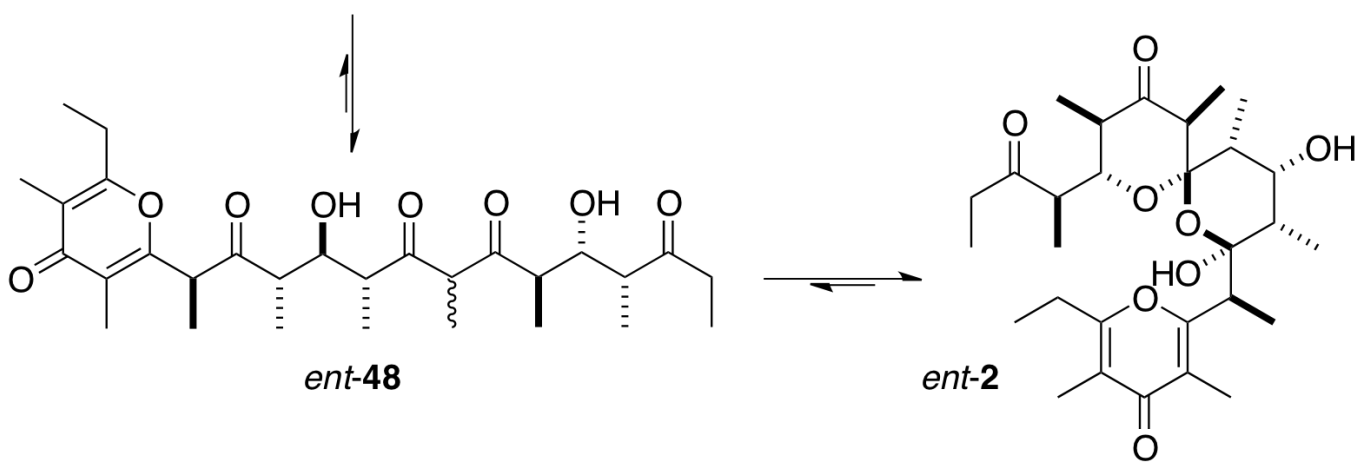

ent-14-epi-6 +

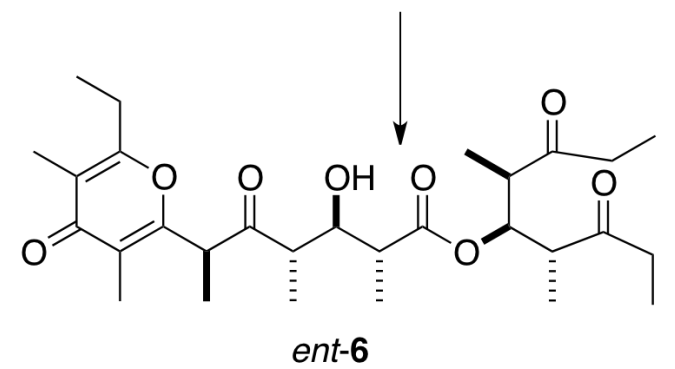

The close correspondence of the spectroscopic data of synthetic ent-3 with those of isolated 3, clearly demonstrated their enantiomeric relationship. The relative configuration assigned to ent-3 is based on the relative configuration of the aldol adduct 191. Although the assignment of the 12,13-anti-13,14-syn relative configuration in 191 was based on spectroscopic 
evidence, the assignment of 10,12-syn was tentative and based on literature precedents (see section 2.4.4). The relatively 'clean' isomerization of ent-3 to ent-2 of known structure clearly confirms for the both the relative and absolute configuration proposed for caloundrin B (3) because both compounds share the same configuration at C-4, C-5, C-6, C-10, C-11, C-12, and C-14, differing only at C-8. Besides, it was proved that ent-3 is thermodynamically less stable than ent-2 and therefore, it cannot be an artifact from isolation. In addition, the hypothesis that proposed $\mathbf{3}$ as the biosynthetic product from which $\mathbf{2 , 4}$, and $\mathbf{6}$ are formed is more viable.

\subsection{Conclusions}

In summary, the first synthesis of ent-3 was achieved in 16 linear steps from ent-102. In the presence of imidazole, ent-3 was cleanly isomerized to ent-siphonarin B ent-2 with no more than traces of ent-3 remaining. The isolation of ent-3 from this experiment clearly establishes that caloundrin B (3) and siphonarin B (2) share the same absolute configurations at all stereocentres (except C-8) and confirms the proposed relative and absolute configuration for $\mathbf{3}$. These results also firmly establish that caloundrin B (3) is thermodynamically much less stable than siphonarin B (2) confirming previous calculations and explaining the failure ${ }^{9}$ to obtain $\mathbf{3}$ by attempted isomerization of 48. Consequently, caloundrin B (3) cannot be an isolation artifact of siphonarin B (2) but presumably is formed in an enzyme-mediated or other templated process. Thus, caloundrin B (2) must now be considered as a plausible biosynthetic product from which the formation of siphonarin B (2), baconipyrone A (4), and baconipyrone C (6) can be readily explained (see section 1.2.2.2).

The synthesis of ent-3 required the development of various methodologies that were crucial for understanding the requirements for formation of the desired trioxaadamantane ring system and for assembling the complete carbon skeleton of ent-3 with the correct relative 
configuration. It was discovered that the C-10 configuration had a profound influence on the thermodynamic stability of the trioxaadamantane ring system. Because of avoidance of synpentane interaction between the methyl groups at $\mathrm{C}-8$ and $\mathrm{C} 10$, the $\mathrm{C}-10$ configuration dictates the orientation between the side chain and the trioxaadamantane. This orientation facilitates a stabilizing H-bond in the trioxaadamantane or a hemiacetal tautomer that strongly influences the position of the equilibrium. Unfortunately, the 'wrong' C-10 configuration was required to allow formation of the trioxaadamantane under thermodynamic control. As a consequence, a correction of the C-10 configuration after formation of a stable trioxaadamantane was required. The rather lengthy isomerization sequence used was effective but a second generation synthesis will be much more efficient if a better solution to this problem can be designed.

Applying the multiplicativity rule to rationally design aldol reactions that proceed with kinetic resolution was shown to be possible in a proof-of-concept study. ${ }^{46}$ During the development of this methodology, an unprecedented non-linear effect was discovered and characterized in which the enantioselectivity was shown to be dependent on the enantiopurity of both reactants. Building on the principles established, aldol reactions of achiral ketones with aldehyde $( \pm)$-30 were shown to be highly Felkin diastereoface selective suggesting that $( \pm)$-30 would react with kinetic resolution with suitable enantiopure ketones. The synthesis of the epimeric ketones ent-95 and ent-10-epi-95 allowed preliminary studies that informed the prediction that the $(E)$-boron enolate of ent-95 would react with $( \pm)$-30 to produce an aldol adduct with the correct selectivity to permit synthesis of ent-3. During the studies, it was discovered that the desired $(E)$-enol borinate of ent-95 could be prepared by transmetallation of the $\mathrm{LiN}^{t} \mathrm{Bu}\left(\mathrm{SiMe}_{3}\right)$-generated $(E)$-Li enolate and its reaction with $( \pm)-\mathbf{3 0}$ gave the desired adduct 
191 (dr 3.3), as predicted. This method of forming boron enolates will be likely be useful in other difficult cases. 


\section{EXPERIMENTAL PROCEDURES}

\subsection{General methods}

Anhydrous solvents were distilled under argon atmosphere as follows: Tetrahydrofuran (THF) from benzophenone sodium ketyl; $\mathrm{CH}_{2} \mathrm{Cl}_{2}$ from $\mathrm{CaH}_{2} ; \mathrm{MeOH}$ from $\mathrm{Mg}(\mathrm{OMe})_{2} ; \mathrm{DMSO}$ from $\mathrm{CaH}_{2}$ at reduced pressure (stored over $4 \AA$ molecular sieves). All experiments involving airand/or moisture-sensitive compounds were conducted in an oven dried round-bottom flask capped with a rubber septum, and attached via a needle and connecting tubing to an argon manifold equipped with mercury bubbler (ca. $5 \mathrm{~mm}$ positive pressure of argon). Low temperature baths were: ice/water $\left(0^{\circ} \mathrm{C}\right), \mathrm{CO}_{2(\mathrm{~s})} / \mathrm{CH}_{3} \mathrm{CN}\left(-50^{\circ} \mathrm{C}\right)$, and $\mathrm{CO}_{2(\mathrm{~s})} /$ acetone $\left(-78{ }^{\circ} \mathrm{C}\right)$. Unless otherwise noted, reaction temperatures refer to that of the bath. Concentration refers to removal of volatiles at water aspirator pressure on a rotary evaporator. Preparative TLC (PTLC) was carried out on glass plates $(20 \times 20 \mathrm{~cm})$ pre-coated $(0.25 \mathrm{~mm})$ with silica gel $60 \mathrm{~F}_{254}$. Materials were detected by visualization under an ultraviolet lamp (254 $\mathrm{nm})$ and/or by treating a $1 \mathrm{~cm}$ vertical strip removed from the plate with a solution of phosphomolybdic acid (5\%) containing a trace of ceric sulfate in aqueous sulfuric acid (5\% v/v) followed by charring on a hot plate. Flash column chromatography (FCC) was performed according to Still et al.1 with silica gel $60(40-63 \mu \mathrm{m})$. All mixed solvent eluents are reported as v/v solutions. Unless otherwise noted, all reported compounds were homogeneous by thin layer chromatography (TLC) and by

${ }^{1}$ H NMR. HPLC experiments were performed using a reverse-phase Zorbax SB-C18 ${ }^{\circledR}$ column (3.6 um particle size silica, $3.0-100 \mathrm{~mm}$ ) and a linear gradient of acetonitrile in water ( $25 \%$ to $75 \%$ ) was employed as the mobile phase (0 to $35 \mathrm{~min}$ ). 


\subsection{Spectral data}

High resolution mass spectra (HRMS) and low resolution mass spectra (LRMS) were obtained on a double focusing high resolution spectrometer; only partial data are reported. EI ionization was accomplished at $70 \mathrm{eV}$ and $\mathrm{CI}$ ionization at $50 \mathrm{eV}$ with ammonia as the reagent gas; only partial data are reported. Alternatively, HRMS were obtained on an LC-MS/MS timeof-flight high resolution spectrometer with electrospray ionization (ESI) from acetonitrile solution. IR spectra were recorded on a Fourier transform interferometer using a diffuse reflectance cell (DRIFT); only diagnostic and/or intense peaks are reported. Unless otherwise noted, NMR spectra were measured in $\mathrm{CDCl}_{3}$ solution at $500 \mathrm{MHz}$ for ${ }^{1} \mathrm{H}$ and $125 \mathrm{MHz}$ for ${ }^{13} \mathrm{C}$. Signals due to the solvent $\left({ }^{13} \mathrm{C}\right.$ NMR) or residual protonated solvent $\left({ }^{1} \mathrm{H}\right.$ NMR $)$ served as the internal standard: $\mathrm{CDCl}_{3}\left(7.26 \delta_{\mathrm{H}}, 77.23 \delta_{\mathrm{C}}\right)$. The ${ }^{1} \mathrm{H}$ NMR chemical shifts and coupling constants were determined assuming first-order behavior. Multiplicity is indicated by one or more of the following: s (singlet), d (doublet), t (triplet), q (quartet), m (multiplet), br (broad), ap (apparent); the list of couplings constants $(J)$ corresponds to the order of the multiplicity assignment. Coupling constants $(J)$ are reported to the nearest $0.5 \mathrm{~Hz}$ (i.e., $\pm 0.25 \mathrm{~Hz}$ as consistent with the digital resolution ca. $0.2 \mathrm{~Hz} / \mathrm{pt}$ ). The ${ }^{1} \mathrm{H}$ NMR assignments were made based on chemical shift and multiplicity and were confirmed by homonuclear decoupling and/or twodimensional correlation experiments (gCOSY, gHSQC, gHMBC). The ${ }^{13} \mathrm{C}$ NMR assignments were made on the basis of chemical shift and multiplicity (as determined by ${ }^{13} \mathrm{C}$-DEPT or gHSQC) and were confirmed by two-dimensional ${ }^{1} \mathrm{H} /{ }^{13} \mathrm{C}$ correlation experiments (gHSQC and/or gHMBC). Specific rotations $\left([\alpha]_{\mathrm{D}}\right)$ are the average of 5 determinations at ambient temperature using a $1 \mathrm{~mL}, 10 \mathrm{dm}$ cell; the units are $10^{-1} \mathrm{deg}^{2} \mathrm{~g} \mathrm{~g}^{-1}$, the concentrations $(c)$ are reported in $\mathrm{g} / 100 \mathrm{~mL}$, and the values are rounded to reflect the accuracy of the measured concentrations (the major source of error). 


\subsection{Materials}

The following compounds and reagents were prepared as described previously: $96 ;^{43}(S)-30 ; ;^{81,82}$ (-)-109 (>98\% ee) and (+)-ent-109 (>98\% ee) $;^{40,}{ }^{46} \mathrm{~W}-2$ Raney nickel; ${ }^{83,84}$ IBX; ${ }^{85}$ DMP (from IBX). ${ }^{86} i \operatorname{Pr}_{2} \mathrm{NH}$ was freshly distilled under argon atmosphere from $\mathrm{CaH}_{2}$. 2,6-Lutidine was distilled from $\mathrm{CaH}_{2}$ and stored over $4 \AA$ molecular sieves. All other reagents were commercially available and unless otherwise noted, were used as received.

\subsection{Experimental procedures and characterization data}

\section{$(3 S, 5 S)-r e l-3-[(R)-(6 S)-1,4-D i o x a-8-t h i a s p i r o[4.5]$ dec-6-yl(triethylsilyloxy)methyl]-5-[(S)-1-} hydroxy-2-methylpropyl]tetrahydro-4H-thiopyran-4-one (118)

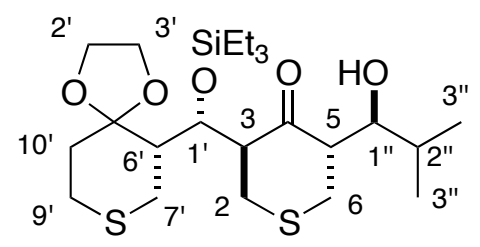

118

A solution of $( \pm)-\mathbf{1 0 2}(500 \mathrm{mg}, 1.19 \mathrm{mmol})$ in $\mathrm{CH}_{2} \mathrm{Cl}_{2}(8 \mathrm{~mL})$ was added via syringe to a stirred solution of $\left(c-\mathrm{C}_{6} \mathrm{H}_{11}\right)_{2} \mathrm{BCl}(1 \mathrm{M}$ in hexanes; $2.4 \mathrm{~mL}, 2.4 \mathrm{mmol})$ and $\mathrm{Et}_{3} \mathrm{~N}(0.350 \mathrm{~mL}, 2.51$ mmol) in $\mathrm{CH}_{2} \mathrm{Cl}_{2}(14 \mathrm{~mL})$ at $0{ }^{\circ} \mathrm{C}$ under Ar. After $30 \mathrm{~min}$, the reaction mixture was cooled to $78{ }^{\circ} \mathrm{C}$ and a solution of isobutyraldehyde $(0.218 \mathrm{~mL}, 2.39 \mathrm{mmol})$ in $\mathrm{CH}_{2} \mathrm{Cl}_{2}(3.5 \mathrm{~mL})$ was added via syringe over ca. $8 \mathrm{~min}$. After $16 \mathrm{~h}$, the reaction was quenched by sequential addition of phosphate buffer $(\mathrm{pH}=7 ; 10 \mathrm{~mL})$, methanol $(3 \mathrm{~mL})$ and $30 \%$ aq $\mathrm{H}_{2} \mathrm{O}_{2}(6 \mathrm{~mL})$ with vigorous stirring. The mixture was warmed to $0{ }^{\circ} \mathrm{C}$ and, after $10 \mathrm{~min}$, was diluted with ice-water and saturated aqueous $\mathrm{Na}_{2} \mathrm{SO}_{3}$ and extracted with $\mathrm{CH}_{2} \mathrm{Cl}_{2}$. The combined organic layers were dried over $\mathrm{Na}_{2} \mathrm{SO}_{4}$ and concentrated to give the crude product whose ${ }^{1} \mathrm{H}$ NMR spectrum suggest the 
presence of a single adduct. Fractionation of the crude by FCC (10-20\% ethyl acetate in hexanes) afforded recovered $102(59 \mathrm{mg}, 12 \%)$ and the title compound as a colorless oil (485 mg, 82\%).

IR $v_{\max } 3544 \mathrm{~cm}^{-1}$.

${ }^{1}$ H NMR (500 MHz, $\left.\mathrm{CDCl}_{3}\right) \delta 4.71$ (1H, br s, HC-1'), 3.98-3.82 (4H, m, HC-2', HC-3'), 3.65 (1H, ddd, $J=4,4,7.5 \mathrm{~Hz}, \mathrm{HC}-1 "), 3.20$ (1H, dd, $J=11,13 \mathrm{~Hz}, \mathrm{HC}-2), 3.06(1 \mathrm{H}, \mathrm{d}, J=4 \mathrm{~Hz}$, HO), 2.96 (1H, dd, $J=5.5,12.5 \mathrm{~Hz}, \mathrm{HC}-6), 2.90-2.73$ (5H, m, HC-3, HC-5, HC-2, $\left.\mathrm{H}_{2} \mathrm{C}-7^{\prime}\right)$, 2.67-2.57 (3H, m, HC-6, $\left.\mathrm{H}_{2} \mathrm{C}-9^{\prime}\right), 2.13-2.06$ (1H, m, HC-6'), 2.06-1.99 (1H, m, HC-10'), 1.83$1.72(1 \mathrm{H}, \mathrm{m}, \mathrm{HC}-2 "), 1.63-1.54\left(1 \mathrm{H}, \mathrm{m}, \mathrm{HC}-10^{\prime}\right), 0.99(3 \mathrm{H}, \mathrm{d}, J=7 \mathrm{~Hz}, \mathrm{HC}-3 "), 0.95$ (9H, t, $J=$ $\left.8 \mathrm{~Hz}, \mathrm{H}_{3} \mathrm{CCSi} \times 3\right), 0.90(3 \mathrm{H}, \mathrm{d}, J=7 \mathrm{~Hz}, \mathrm{HC}-3 "), 0.64$ (6H, ap q, $\left.J=8 \mathrm{~Hz}, \mathrm{H}_{2} \mathrm{CSi} \times 3\right)$.

${ }^{13}$ C NMR (125 MHz, CDCl $)$ ) 211.9 (s, C-4), 109.0 (s, C-5'), 77.7 (d, C-1"), 69.3 (d, C-1'), 64.5 (t, C-2' or C-3'), 63.8 (t, C-2' or C-3'), 60.6 (d, C-3), 51.3 (d, C-5), 47.8 (d, C-6'), 34.5 (t, C-10'), 29.8 (d, C-2"), 29.4 (t, C-7'), 27.1 (t, C-6), 26.8 (t, C-9'), 26.1 (t, C-2), 20.3 (q, C-3"), 15.4 (q, C3"), $7.1\left(\mathrm{q} \times 3, \mathrm{CH}_{3} \mathrm{CSi}\right), 5.3\left(\mathrm{t} \times 3, \mathrm{CH}_{2} \mathrm{Si}\right)$.

LRMS (CI, $\mathrm{NH}_{3}$ ), m/z (relative intensity): 491 ([M+1] $\left.{ }^{+}, 1\right), 419$ (24), 389 (23), 303 (37), 287 (70), 229 (100), 132 (36), 99 (53).

HRMS $m / z$ calcd for $\mathrm{C}_{23} \mathrm{H}_{42} \mathrm{O}_{5} \mathrm{~S}_{2} \mathrm{Si}+\mathrm{H}$ : 491.2321; found: 491.2302 (CI, $\mathrm{NH}_{3}$ ). 
(4S,4aS,5aR,9aS,10R,10aS,12S)-rel-Octahydro-5a,4,10-(epoxymethenoxy)-4a-hydroxy-12-

(1-methylethyl)-1H,4a $H, 5 a H$-bisthiopyrano[4,3-b:3',4'-e]pyran (119)

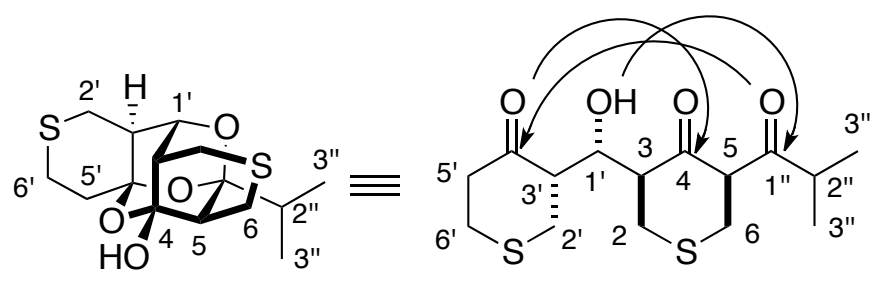

119

IBX (1.04 g, $3.71 \mathrm{mmol})$ was added to a stirred solution of aldol adduct 118 (485 mg, $0.989 \mathrm{mmol})$ in dry DMSO $(70 \mathrm{~mL})$ at room temperature under Ar. After $10 \mathrm{~h}$, the mixture was diluted with ethyl acetate and washed sequentially with saturated aq $\mathrm{NaHCO}_{3}, \mathrm{H}_{2} \mathrm{O}$ and brine. The organic layer was dried over $\mathrm{Na}_{2} \mathrm{SO}_{4}$ and concentrated to give the crude product that was taken up in acetone $(225 \mathrm{ml}) . \mathrm{FeCl}_{3} \cdot 6 \mathrm{H}_{2} \mathrm{O}(374 \mathrm{mg}, 1.39 \mathrm{mmol})$ was added to the stirred solution and the resulting dark brown mixture was heated under reflux. After $12.5 \mathrm{~h}$ (the solution was yellow), the mixture was diluted with ethyl acetate and washed sequentially with saturated aq $\mathrm{NaHCO}_{3}, \mathrm{H}_{2} \mathrm{O}$ and brine. The organic layer was dried over $\mathrm{Na}_{2} \mathrm{SO}_{4}$, concentrated and fractionated by FCC (30\% ethyl acetate in hexanes) to give the title compound as a yellow solid (219 mg, 63\% over 2 steps).

IR $v_{\max } 3397 \mathrm{~cm}^{-1}$.

${ }^{1} \mathbf{H}$ NMR $\left(500 \mathrm{MHz}, \mathrm{CDCl}_{3}\right) \delta 4.28(1 \mathrm{H}, \mathrm{d}, J=3 \mathrm{~Hz}, \mathrm{HC}-1$ ') $3.55(1 \mathrm{H}, \mathrm{dd}, J=3.5,14 \mathrm{~Hz}, \mathrm{HC}-$ 2), 3.40 (1H, dd, $J=3,14 \mathrm{~Hz}, \mathrm{HC}-6), 2.97$ (1H, ddd, $J=3,13.5,13.5 \mathrm{~Hz}, \mathrm{HC}-6$ '), 2.81 (1H, dd, $J$ $\left.=12.5,13 \mathrm{~Hz}, \mathrm{HC}-2^{\prime}\right), 2.79$ (1H, br s, HO), 2.56 (2H, br d, $\left.J=14 \mathrm{~Hz}, \mathrm{HC}-2, \mathrm{HC}-6\right), 2.44$ (1H, , $\left.=2.5,3,4,13.5 \mathrm{~Hz}, \mathrm{HC}-6^{\prime}\right), 2.40\left(1 \mathrm{H}, \mathrm{ddd}, J=3,3,12.5 \mathrm{~Hz}, \mathrm{HC}-3{ }^{\prime}\right), 2.23(1 \mathrm{H}, \mathrm{ddd}, J=3,3,13$ Hz, HC-2'), 2.12 (1H, br s, HC-3), 2.09 (1H, br s, HC-5), 2.04-1.98 (2H, m, HC-2", HC-5'), 1.87 
(1H, ddd, $\left.J=4,13.5,13.5 \mathrm{~Hz}, \mathrm{HC}-5^{\prime}\right), 1.04$ (3H, d, $\left.J=7 \mathrm{~Hz}, \mathrm{HC}-3 "\right), 0.90$ (3H, d, $J=7 \mathrm{~Hz}, \mathrm{HC}-$ 3").

${ }^{13}$ C NMR (125 MHz, $\left.\mathrm{CDCl}_{3}\right)$ \& 102.9 (s, C-1"), 99.0 (s, C-4'), 95.1 (s, C-4), 76.8 (d, C-1'), 45.1 (d, C-3'), 41.5 (d, C-5), 37.6 (t, C-5'), 35.6 (d, C-3), 32.8 (d, C-2"), 28.9 (t, C-2), 27.5 (t, C-2'), 25.2 (t, C-6'), 24.4 (t, C-6), 15.9 (q, C-3"), 15.1 (q, C-3").

LRMS (EI), m/z (relative intensity): 330 ([M] $\left.]^{+}, 100\right), 242$ (34), 209 (29), 154 (31), 153 (35), 126 (52), 99 (37), 71 (61), 67 (70).

HRMS $m / z$ calcd for $\mathrm{C}_{15} \mathrm{H}_{22} \mathrm{O}_{4} \mathrm{~S}_{2}: 330.0960$; found: 330.0968 (EI).

\section{$(1 R, 3 R, 5 R, 7 R, 8 S, 9 S, 10 S)-r e l-3-E t h y l-8,9,10-t r i m e t h y l-5-(1-m e t h y l) e t h y l-2,4,6-$}

trioxatricyclo[3.3.1.1 $\left.{ }^{3,7}\right]$ decan-1-ol (120)

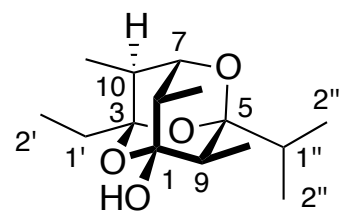

120

Raney nickel (W2; $2 \mathrm{~mL}$ settled volume) was transferred to a solution of 119 (50 mg, $0.15 \mathrm{mmol})$ in absolute ethanol $(1 \mathrm{~mL})$ and the resulting suspension was heated under reflux with vigorous stirring in a (previously heated) oil bath at $80^{\circ} \mathrm{C}$. The reaction was monitored by TLC and after $30 \mathrm{~min}$, additional Raney nickel $(0.5 \mathrm{~mL})$ was added. After $40 \mathrm{~min}$, the suspension was allowed to settle and the supernatent was decanted. The solid was resuspended in ethanol and heated under reflux for $10 \mathrm{~min}$. This washing procedure was repeated with ethanol, with methanol and acetone. The combined supernatents were filtered through Celite ${ }^{\circ}$, concentrated, and fractionated by FCC ( $20 \%$ ethyl acetate in hexane) to obtain the title compound as a white solid (25 mg, 61\%). 
IR $v_{\max } 3398 \mathrm{~cm}^{-1}$.

${ }^{1} \mathbf{H}$ NMR $\left(500 \mathrm{MHz}, \mathrm{CDCl}_{3}\right) \delta 3.85(1 \mathrm{H}, \mathrm{d}, J=3 \mathrm{~Hz}, \mathrm{HC}-7), 2.57(1 \mathrm{H}, \mathrm{s}, \mathrm{HO}), 2.13(1 \mathrm{H}, \mathrm{dq}, J=$ 3, $7 \mathrm{~Hz}, \mathrm{HC}-10), 2.07$ (1H, br q, $J=7.5 \mathrm{~Hz}, \mathrm{HC}-8), 1.98(1 \mathrm{H}, \mathrm{dq}, J=1.5,6.5 \mathrm{~Hz}, \mathrm{HC}-9), 1.86$ $\left(1 \mathrm{H}, \mathrm{qq}, J=6.5,7 \mathrm{~Hz}, \mathrm{HC}-2^{\prime \prime}\right), 1.63-1.49\left(2 \mathrm{H}, \mathrm{m}, \mathrm{H}_{2} \mathrm{C}-1^{\prime}\right), 1.18\left(3 \mathrm{H}, \mathrm{d}, J=7.5 \mathrm{~Hz}, \mathrm{H}_{3} \mathrm{CC}-8\right)$, $1.06\left(3 \mathrm{H}, \mathrm{d}, J=6.5 \mathrm{~Hz}, \mathrm{H}_{3} \mathrm{CC}-9\right), 0.99$ (3H, d, $\left.J=6.5 \mathrm{~Hz}, \mathrm{H}_{3} \mathrm{C}-2 "\right), 0.92-0.86$ (9H, m, H ${ }_{3} \mathrm{C}-2 "$, $\left.\mathrm{H}_{3} \mathrm{C}-2{ }^{\prime}, \mathrm{H}_{3} \mathrm{CC}-10\right)$.

${ }^{13}$ C NMR (125 MHz, CDCl $)$ ) 102.9 (s, C-3), 102.7 (s, C-5), 98.9 (s, C-1), 79.1 (d, C-7), 43.8 (d, C-9), 37.3 (d, C-10), 35.4 (d, C-8), 32.7 (d, C-1"), 29.7 (t, C-1'), 16.0 (q, C-2"), 15.2 (q, C-2"), 14.6 (q, $\left.\mathrm{CH}_{3} \mathrm{C}-8\right), 12.9$ (q, $\left.\mathrm{CH}_{3} \mathrm{C}-10\right), 10.4$ (q, $\left.\mathrm{CH}_{3} \mathrm{C}-9\right), 6.4$ (q, C-2').

LRMS (CI, $\mathrm{NH}_{3}$ ), $m / z$ (relative intensity): 271 ([M+1] $\left.]^{+}, 31\right), 253$ (100), 249 (20), 183 (35), 165 (21), 153 (17), 127 (20), 125 (22), 96 (22), 71 (29).

HRMS $m / z$ calcd for $\mathrm{C}_{15} \mathrm{H}_{26} \mathrm{O}_{4}+\mathrm{H}: 271.1909$; found: $271.1902\left(\mathrm{CI}, \mathrm{NH}_{3}\right)$.

$(3 S, 5 S)-3-[(R)-(6 S)-1,4-D i o x a-8-t h i a s p i r o[4.5]$ dec-6-yl(triethylsilyloxy)methyl]-5-[(S)-(2S)-1hydroxy-2-methyl-3-(phenylmethoxy)propyl]tetrahydro-4H-thiopyran-4-one (130)

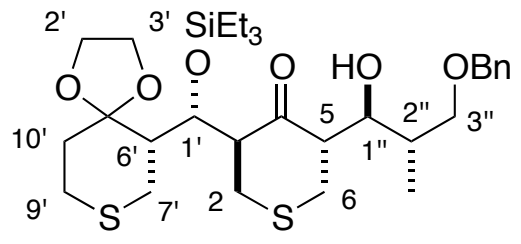

130

A solution of (-)-102 (300 mg, $0.716 \mathrm{mmol})$ in $\mathrm{CH}_{2} \mathrm{Cl}_{2}(4 \mathrm{~mL})$ was added via syringe in 2 min to a stirred solution of $\left(c-\mathrm{C}_{6} \mathrm{H}_{11}\right)_{2} \mathrm{BCl}(1 \mathrm{M}$ in hexanes; $1.4 \mathrm{~mL}, 1.4 \mathrm{mmol})$ and $\mathrm{Et}{ }_{3} \mathrm{~N}(0.210$ $\mathrm{mL}, 1.50 \mathrm{mmol})$ in $\mathrm{CH}_{2} \mathrm{Cl}_{2}(6 \mathrm{~mL})$ at $0{ }^{\circ} \mathrm{C}$ under Ar. After $30 \mathrm{~min}$, the reaction mixture was cooled to $-78{ }^{\circ} \mathrm{C}$ and a solution of Roche aldehyde $(S)-29(241 \mathrm{mg}, 1.35 \mathrm{mmol})$ in $\mathrm{CH}_{2} \mathrm{Cl}_{2}$ (4 
$\mathrm{mL}$ ) was added slowly via syringe (ca. $10 \mathrm{~min}$ ). After $18 \mathrm{~h}$, the reaction was quenched by sequential addition of phosphate buffer $(\mathrm{pH} 7 ; 7 \mathrm{~mL})$ and $\mathrm{MeOH}(2 \mathrm{~mL})$. The mixture was then transferred to an ice bath and $30 \%$ aq $\mathrm{H}_{2} \mathrm{O}_{2}(4.5 \mathrm{~mL})$ was added with vigorous stirring. After 10 min, the mixture was diluted with ice-water and saturated aq $\mathrm{Na}_{2} \mathrm{SO}_{3}$ and extracted with $\mathrm{CH}_{2} \mathrm{Cl}_{2}$. The combined organic layers were dried over $\mathrm{Na}_{2} \mathrm{SO}_{4}$, concentrated, and fractionated by FCC ( $2 \%$ ethyl acetate in dichloromethane) to obtain recovered $102(51 \mathrm{mg}, 17 \%)$ and the title compound as a colorless oil (350 mg, $82 \%)$.

$[\alpha]_{\mathrm{D}}-58\left(c 2.2, \mathrm{CHCl}_{3}\right)$

IR $v_{\max } 3517 \mathrm{~cm}^{-1}$.

${ }^{1} \mathbf{H}$ NMR $\left(500 \mathrm{MHz}, \mathrm{CDCl}_{3}\right) \delta$ 7.37-7.25 (5H, m, Ph), $4.70(1 \mathrm{H}, \mathrm{br} \mathrm{s}, \mathrm{HC}-1$ '), $4.52(1 \mathrm{H}, \mathrm{d}, J=12$ Hz, HCPh) 4.49 (1H, d, $J=12 \mathrm{~Hz}, \mathrm{HCPh}), 3.90-3.70$ (5H, m, HC-1", $\mathrm{H}_{2} \mathrm{C}-2 ', \mathrm{H}_{2} \mathrm{C}-3$ '), 3.65 (1H, dd, $J=7,9 \mathrm{~Hz}, \mathrm{HC}-3 "), 3.44$ (1H, dd, H= 5, 9 Hz, HC-3") 3.43 (1H, d, $J=4.5 \mathrm{~Hz}, \mathrm{HO}), 3.17-$ $3.11(2 \mathrm{H}, \mathrm{m}, \mathrm{HC}-2$, HC-6), 3.05 (1H, ddd, $J=6,6,9 \mathrm{~Hz}, \mathrm{HC}-5), 2.91-2.85$ (1H, m, HC-3), 2.85$2.77\left(3 \mathrm{H}, \mathrm{m}, \mathrm{HC}-2, \mathrm{H}_{2} \mathrm{C}-7^{\prime}\right), 2.71(1 \mathrm{H}, \mathrm{dd}, J=9.5,12 \mathrm{~Hz}, \mathrm{HC}-6), 2.64-2.61\left(2 \mathrm{H}, \mathrm{m}, \mathrm{H}_{2} \mathrm{C}-9\right.$ '), 2.11-2.02 (3H, m, HC-2", HC-6', HC-10'), 1.58 (1H, ap ddd, $\left.J=6,6,14 \mathrm{~Hz}, \mathrm{HC}-10^{\prime}\right), 1.03(3 \mathrm{H}$, d, $\left.J=7 \mathrm{~Hz}, \mathrm{H}_{3} \mathrm{CC}-2 "\right), 0.96\left(9 \mathrm{H}, \mathrm{t}, J=8 \mathrm{~Hz}, \mathrm{H}_{3} \mathrm{CCSi} \times 3\right), 0.64\left(6 \mathrm{H}\right.$, ap q, $\left.J=8 \mathrm{~Hz}, \mathrm{H}_{2} \mathrm{CSi} \times 3\right)$.

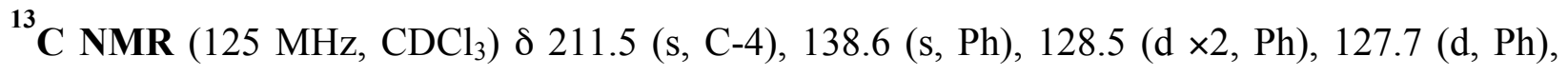
$127.6(\mathrm{~d} \times 2, \mathrm{Ph}), 109.1$ (s, C-5'), $75.2(\mathrm{~d}, \mathrm{C}-1 "), 73.5\left(\mathrm{t}, \mathrm{CH}_{2} \mathrm{Ph}\right), 72.4$ (t, C-3"), $69.2\left(\mathrm{~d}, \mathrm{C}-1^{\prime}\right)$, 64.5 (t, C-2'), 63.9 (t, C-3'), 60.4 (d, C-3), 51.9 (d, C-5), 47.8 (d, C-6'), 35.6 (d, C-2"), 34.6 (t, C10'), 29.5 (t, C-7'), 27.7 (t, C-6), 26.9 (t, C-9'), 26.3 (t, C-2), 15.8 (q, $\left.\mathrm{CH}_{3} \mathrm{C}-2 "\right), 7.2$ (q ×3, $\left.\mathrm{CH}_{3} \mathrm{CSi}\right), 5.3\left(\mathrm{t}, \mathrm{CH}_{2} \mathrm{Si}\right)$. 
LRMS (EI), $m / z$ (relative intensity): 596 ([M] $\left.{ }^{+}, 2\right), 567$ (10), 551 (20), 550 (35), 549 (100), 521 (10), $506(8)$.

HRMS $m / z$ calcd for $\mathrm{C}_{30} \mathrm{H}_{48} \mathrm{O}_{6} \mathrm{SiS}_{2}+\mathrm{Na}: 619.2553$; found: 619.2540 (ESI).

(4S,4aS,5aR,9a $S, 10 R, 10 \mathrm{a} S, 12 S)$-Octahydro-5a,4,10-(epoxymethenoxy)-4a-hydroxy-12-[(S)1-methyl-2-(phenylmethoxy)ethyl]-1H,4aH,5aH-bisthiopyrano[4,3-b:3',4'-e]pyran (131)

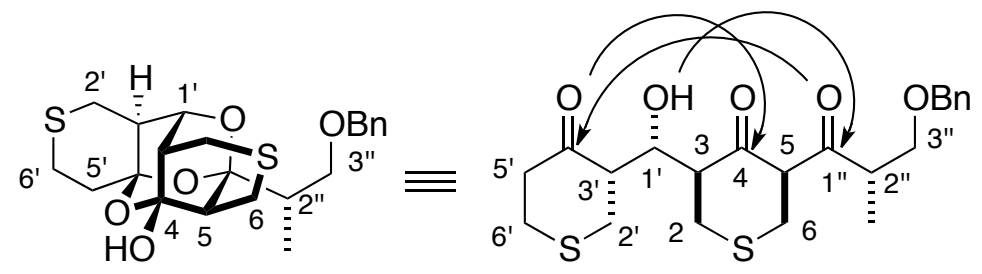

IBX (155 mg, $0.555 \mathrm{mmol})$ was added to a stirred solution of aldol adduct $\mathbf{1 3 0}(88 \mathrm{mg}$, $0.15 \mathrm{mmol})$ in dry DMSO $(10 \mathrm{~mL})$ at room temperature under Ar. After $5.5 \mathrm{~h}$, the mixture was diluted with ethyl acetate and washed sequentially with saturated aq $\mathrm{NaHCO}_{3}, \mathrm{H}_{2} \mathrm{O}$ and brine, dried over $\mathrm{Na}_{2} \mathrm{SO}_{4}$, and concentrated to give the crude dione (mainly enol form by ${ }^{1} \mathrm{H} \mathrm{NMR}$ ). $\mathrm{FeCl}_{3} \cdot 6 \mathrm{H}_{2} \mathrm{O}(56 \mathrm{mg}, 0.21 \mathrm{mmol})$ was added to a stirred solution of the above crude in acetone $(33.6 \mathrm{~mL})$ and the resulting purple solution was heated under reflux. After $12 \mathrm{~h}$ (reaction mixture had turned yellow), the mixture was diluted with ethyl acetate and washed sequentially with saturated aq $\mathrm{NaHCO}_{3}, \mathrm{H}_{2} \mathrm{O}$ and brine, dried over $\mathrm{Na}_{2} \mathrm{SO}_{4}$, concentrated, and fractionated by FCC ( $25 \%$ ethyl acetate in hexanes). The fraction containing the desired product was refractionated by PTLC (30\% ethyl acetate in hexanes x 3 ) to give the title compound (38 mg, 58\%).

$[\alpha]_{\mathrm{D}}+15\left(c 0.7, \mathrm{CHCl}_{3}\right)$

IR $v_{\max } 3384 \mathrm{~cm}^{-1}$. 
${ }^{1}$ H NMR $\left(500 \mathrm{MHz}, \mathrm{CDCl}_{3}\right) \delta 7.34(4 \mathrm{H}, \mathrm{d}, J=4.5 \mathrm{~Hz}, \mathrm{Ph}), 7.31-7.24(1 \mathrm{H}, \mathrm{m}, \mathrm{Ph}), 4.55(1 \mathrm{H}, \mathrm{d}$, $J=12 \mathrm{~Hz}, \mathrm{HCPh}), 4.46(1 \mathrm{H}, \mathrm{d}, J=12 \mathrm{~Hz}, \mathrm{HCPh}), 4.30\left(1 \mathrm{H}, \mathrm{br} \mathrm{d}, J=3 \mathrm{~Hz}, \mathrm{HC}-1^{\prime}\right) 4.03$ (1H, dd, $J=3,9 \mathrm{~Hz}, \mathrm{HC}-2 "), 3.54$ (1H, dd, $J=3.5,14 \mathrm{~Hz}, \mathrm{HC}-2), 3.42-3.35$ (2H, m, HC-2", HC-6), 2.95 $\left(1 \mathrm{H}, \mathrm{dt}, J=2.5,13,14 \mathrm{~Hz}, \mathrm{HC}-6^{\prime}\right), 2.80\left(1 \mathrm{H}, \mathrm{dd}, J=12.5,13 \mathrm{~Hz}, \mathrm{HC}-2^{\prime}\right), 2.57-2.53$ (2H, m, HC2, HC-6), 2.43 (1H, dddd, $J=3,3,4,14$ Hz, HC-6'), 2.35 (1H, ddd, $\left.J=3.5,4,12.5 \mathrm{~Hz}, \mathrm{HC}-3^{\prime}\right)$, 2.27-2.17 (2H, m, HC-2', HC-2"), 2.14-2.09 (2H, m, HC-3, HC-5), 2.00 (1H, ddd, J= 2.5, 3, 14 Hz, HC-5'), $1.81\left(1 \mathrm{H}, \mathrm{dt}, J=4,13,14 \mathrm{~Hz}, \mathrm{HC}-5^{\prime}\right), 1.64(1 \mathrm{H}, \mathrm{br}$ s, HO), $1.06(3 \mathrm{H}, \mathrm{d}, J=7 \mathrm{~Hz}$, HC-3").

${ }^{13}$ C NMR (500 MHz, $\left.\mathrm{CHCl}_{3}\right)$ \& $138.9(\mathrm{~s}, \mathrm{Ph}), 128.5(\mathrm{~d} \times 2, \mathrm{Ph}), 127.8(\mathrm{~d} \times 2, \mathrm{Ph}), 127.6(\mathrm{~d}, \mathrm{Ph})$, 102.9 (s, C-1"), 99.0 (s, C-4'), 95.0 (s, C-4), 76.9 (d, C-1'), 73.4 (t, $\mathrm{CH}_{2} \mathrm{Ph}$ ), 70.8 (t, C-3"), 45.2 (d, C-3'), $41.4(\mathrm{~d}, \mathrm{C}-5), 38.8$ (d, C-2"), 37.5 (t, C-5'), 35.6 (d, C-3), 28.9 (t, C-2), 27.5 (t, C-2'), 25.2 (t, C-6'), 24.4 (t, C-6), 11.6 (q, $\left.\mathrm{CH}_{3} \mathrm{C}-1^{\prime \prime}\right)$.

LRMS (EI), $m / z$ (relative intensity): 436 ([M] $\left.]^{+}, 29\right), 259$ (23), 241 (20), 153 (15), 91 (100), 67 (25), 55 (16).

HRMS $m / z$ calcd for $\mathrm{C}_{22} \mathrm{H}_{28} \mathrm{O}_{5} \mathrm{~S}_{2}: 436.1378$; found: 436.1390 (EI).

(4R,5S,6R)-6-(2-Ethyl-1,3-dioxolan-2-yl)-5-triethylsilyloxy-4-methylheptan-3-one (ent-109).

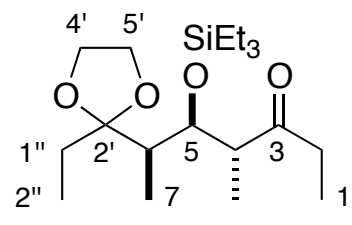

(-)-109 (ent-109)

Raney nickel (W2; $20 \mathrm{~mL}$ settled volume) was transferred to a solution of (+)-102 (4.20 g, 10.0 mmol) in absolute ethanol $(30 \mathrm{~mL})$ and the resulting suspension was heated under reflux with vigorous stirring in an oil bath previously heated to $80^{\circ} \mathrm{C}$. The reaction was monitored by TLC 
and additional Raney nickel (5 mL settled volume) was added at ca. 40 min intervals. After a 5.5 $\mathrm{h}$ (30 $\mathrm{mL}$ of additional Raney nickel added), the reaction mixture was allowed to settle and the supernatant was decanted. The solid was suspended in ethanol $(50 \mathrm{~mL})$ and heated under reflux for 10 min with vigorous stirring and then the mixture was allowed to settle and the supernatant was decanted. The washing procedure was repeated 4 times and then 5 times using methanol. The combined supernatants were filtered through Celite ${ }^{\circledR}$, concentrated, and fractionated by FCC (10\% ethyl acetate in hexane) to obtain the titled compound as a colorless oil (2.9 g, 80\%). $[\alpha]_{\mathrm{D}}-68\left(c 1.0, \mathrm{CHCl}_{3}\right)$

IR $v_{\max }: 1714 \mathrm{~cm}^{-1}$

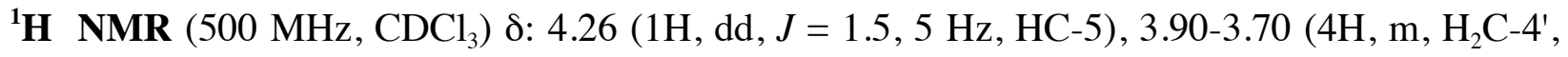
$\mathrm{H}_{2} \mathrm{C}-5$ '), $2.79(1 \mathrm{H}, \mathrm{dq}, J=5.5,7 \mathrm{~Hz}, \mathrm{HC}-4), 2.59(1 \mathrm{H}, \mathrm{dq}, J=18,7 \mathrm{~Hz}, \mathrm{HC}-2), 2.44(1 \mathrm{H}, \mathrm{dq}, J=$ 18, $7 \mathrm{~Hz}, \mathrm{HC}-2), 1.78(1 \mathrm{H}, \mathrm{dq}, J=1.5,7 \mathrm{~Hz}, \mathrm{HC}-6), 1,68(1 \mathrm{H}, \mathrm{dq}, J=14.5,7.5 \mathrm{~Hz}, \mathrm{HC}-1 "), 1.60$ $(1 \mathrm{H}, \mathrm{dq}, J=14.5,7.5 \mathrm{~Hz}, \mathrm{HC}-1 "), 1.03\left(3 \mathrm{H}, \mathrm{t}, J=7 \mathrm{~Hz}, \mathrm{H}_{3} \mathrm{C}-1\right), 1.00\left(3 \mathrm{H}, \mathrm{d}, J=7 \mathrm{~Hz}, \mathrm{H}_{3} \mathrm{CC}-4\right)$, $0.97\left(9 \mathrm{H}, \mathrm{t}, J=8 \mathrm{~Hz}, \mathrm{H}_{3} \mathrm{CCSi} \times 3\right), 0.90\left(3 \mathrm{H}, \mathrm{d}, J=7 \mathrm{~Hz}, \mathrm{H}_{3} \mathrm{C}-7\right), 0.82\left(3 \mathrm{H}, \mathrm{t}, J=7.5 \mathrm{~Hz}, \mathrm{H}_{3} \mathrm{C}-\right.$ 2"), $0.61\left(6 \mathrm{H}\right.$, ap q, $\left.J=8 \mathrm{~Hz}, \mathrm{H}_{2} \mathrm{CSi} \times 3\right)$

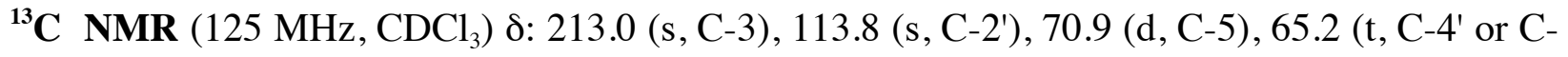
5'), 64.9 (t, C-4' or C-5'), 54.0 (d, C-4), 40.8 (d, C-6), 36.3 (t, C-2), 26.2 (t, C-1"), $10.9\left(\mathrm{q}, \mathrm{CH}_{3} \mathrm{C}-\right.$ 4), 10.5 (q, C-7), 7.7 (q, C-1), $7.2\left(\mathrm{t} \times 3, \mathrm{CH}_{2} \mathrm{Si}\right), 7.1(\mathrm{q}, \mathrm{C}-2 "), 5.4\left(\mathrm{q} \times 3, \mathrm{CH}_{3} \mathrm{CSi}\right)$

LRMS $\left(\mathrm{CI}, \mathrm{NH}_{3}\right), m / z$ (relative intensity): $359\left([\mathrm{M}]^{+}, 10\right), 227$ (36), 101 (100)

HRMS $m / z$ calcd for $\mathrm{C}_{19} \mathrm{H}_{38} \mathrm{O}_{4} \mathrm{Si}+\mathrm{H}: 359.2618$; found: $359.2623\left(\mathrm{CI}, \mathrm{NH}_{3}\right.$ ). 
(4S,5R,6S)-6-(2-Ethyl-1,3-dioxolan-2-yl)-5-triethylsilyloxy-4-methylheptan-3-one (109).

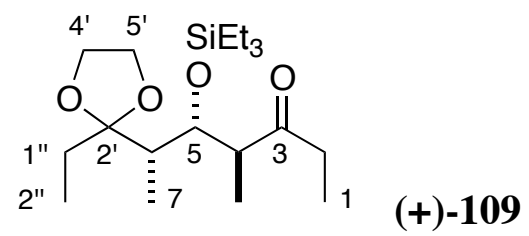

Raney nickel (W2; $20 \mathrm{~mL}$ settled volume) was transferred to a solution of (-)-102 (0.510 g, 1.22 mmol) in absolute ethanol $(43 \mathrm{~mL})$ and the resulting suspension was heated under reflux with vigorous stirring in an oil bath previously heated to $80{ }^{\circ} \mathrm{C}$. The reaction was monitored by TLC and after a $25 \mathrm{~min}$, the reaction mixture was allowed to settle and the supernatant was decanted. The solid was suspended in ethanol $(50 \mathrm{~mL})$ and heated under reflux for $10 \mathrm{~min}$ with vigorous stirring and then the mixture was allowed to settle and the supernatant was decanted. The washing procedure was repeated 2 times and then 3 times using methanol and 3 times using acetone. The combined supernatants were filtered through Celite $\AA$, concentrated, and fractionated by FCC (10\% ethyl acetate in hexane) to obtain the titled compound as a colorless oil $(373 \mathrm{mg}, 85 \%) \cdot[\alpha]_{\mathrm{D}}+70\left(c 1.0, \mathrm{CHCl}_{3}\right)$; NMR data for $(+)-\mathbf{1 0 9}$ were consistent with those reported for (-)-109.

(4S,5R,6S)-rel-6-(2-Ethyl-1,3-dioxolan-2-yl)-5-triethylsilyloxy-4-methylheptan-3-one (109).

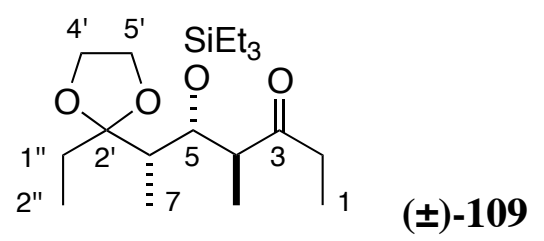

Raney nickel (W2; $14 \mathrm{~mL}$ settled volume) was transferred to a solution of $( \pm)-102$ (522 mg, $1.246 \mathrm{mmol})$ in absolute ethanol (44 $\mathrm{mL})$ and the resulting suspension was heated under reflux with vigorous stirring in an oil bath previously heated to $80{ }^{\circ} \mathrm{C}$. The reaction was monitored by TLC and after $20 \mathrm{~min}$, additional Raney nickel (6 mL settled volume) was added. After $30 \mathrm{~min}$, 
the reaction mixture was allowed to settle and the supernatant was decanted. The solid was suspended in ethanol and heated under reflux for 10 min with vigorous stirring and then the mixture was allowed to settle and the supernatant was decanted. The washing procedure was repeated 2 times and then 3 times using methanol and 3 times using acetone. The combined supernatants were filtered through Celite $\AA$, concentrated, and fractionated by FCC (10\% ethyl acetate in hexane) to obtain the titled compound as a colorless oil (360 mg, 80\%). NMR data for ( \pm -109 were consistent with those reported for (-)-109.

\section{(2S,3R,4S,6S,7S)-rel-2-(2-Ethyl-1,3-dioxolan-2-yl)-3-triethylsilyloxy-7-hydroxy-4,6,8-}

\section{trimethylnonan-5-one (135)}

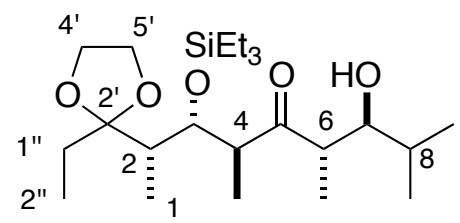

Raney nickel (W2; $10 \mathrm{~mL}$ settled volume) was transferred to a solution of aldol adduct $118(293 \mathrm{mg}, 0.597 \mathrm{mmol})$ in absolute ethanol $(10 \mathrm{~mL})$ and the resulting suspension was heated under reflux with vigorous stirring in an oil bath at $80{ }^{\circ} \mathrm{C}$ (previously heated). After $40 \mathrm{~min}$, the mixture was allowed to settle and the supernatent decanted. The solid was suspended in ethanol heated under reflux for $10 \mathrm{~min}$, and decanted. The washing procedure was repeated with

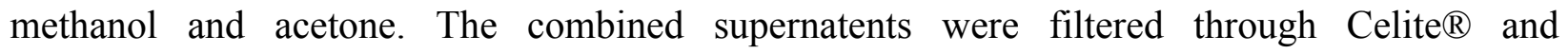
concentrated to give the title compound $(237 \mathrm{mg}, 92 \%)$ that was homogeneous by ${ }^{1} \mathrm{H}$ NMR.

IR $v_{\max } 3508 \mathrm{~cm}^{-1}$.

${ }^{1} \mathbf{H}$ NMR $\left(500 \mathrm{MHz}, \mathrm{CDCl}_{3}\right) \delta 4.27(1 \mathrm{H}, \mathrm{dd}, J=1.5,5 \mathrm{~Hz}, \mathrm{HC}-3), 3.90-3.80\left(4 \mathrm{H}, \mathrm{m}, \mathrm{H}_{2} \mathrm{C}-4\right.$ ', $\mathrm{H}_{2} \mathrm{C}-5$ '), 3.44 (1H, ddd, $\left.J=4,6,7 \mathrm{~Hz}, \mathrm{HC}-7\right), 3.03$ (1H, dq, $\left.J=5,7 \mathrm{~Hz}, \mathrm{HC}-4\right), 2.89$ (1H, dq, $J=$ 
7, $7 \mathrm{~Hz}, \mathrm{HC}-6), 2.27(1 \mathrm{H}, \mathrm{d}, J=6 \mathrm{~Hz}, \mathrm{HO}), 1.90(1 \mathrm{H}, \mathrm{dq}, J=1,7 \mathrm{~Hz}, \mathrm{HC}-2), 1.80-1.57$ (3H, m, $\mathrm{H}_{2} \mathrm{C}-1$ ", HC-8), 1.07 (3H, d, $\left.J=7 \mathrm{~Hz}, \mathrm{H}_{3} \mathrm{CC}-6\right), 1.04\left(3 \mathrm{H}, \mathrm{d}, J=7 \mathrm{~Hz}, \mathrm{H}_{3} \mathrm{CC}-4\right), 1-0.95$ (12H, m, $\left.\mathrm{H}_{3} \mathrm{C}-9, \mathrm{H}_{3} \mathrm{CCSi} \times 3\right), 0.94\left(3 \mathrm{H}, \mathrm{d}, J=7 \mathrm{~Hz}, \mathrm{H}_{3} \mathrm{C}-1\right), 0.91\left(3 \mathrm{H}, \mathrm{d}, J=6.5 \mathrm{~Hz}, \mathrm{H}_{3} \mathrm{C}-9\right), 0.84(3 \mathrm{H}, \mathrm{t}$, $\left.J=7.5 \mathrm{~Hz}, \mathrm{H}_{3} \mathrm{C}-2 "\right), 0.64\left(6 \mathrm{H}\right.$, ap q, $\left.J=8 \mathrm{~Hz}, \mathrm{H}_{2} \mathrm{CSi} \times 3\right)$.

${ }^{13}$ C NMR (125 MHz, $\left.\mathrm{CDCl}_{3}\right)$ \& 217.4 (s, C-5), 114.0 (s, C-2'), 79.1 (d, C-7), 69.9 (d, C-3), 65.3 (t, C-4'), 64.9 (t, C-5'), 55.3 (d, C-4), 48.7 (d, C-6), 40.9 (d, C-2), 30.3 (d, C-8), 26.5 (t, C-1"), 20.2 (q, C-9), 15.4 (q, C-9), 13.5 (q, $\mathrm{CH}_{3} \mathrm{C}-6$ ), 11.4 (q, $\left.\mathrm{CH}_{3} \mathrm{C}-4\right), 10.7$ (q, C-1), 7.3 (q, C-2"), 7.3 $\left(\mathrm{q} \times 3, \mathrm{CH}_{3} \mathrm{CSi}\right), 5.5\left(\mathrm{t} \times 3, \mathrm{CH}_{2} \mathrm{Si}\right)$.

LRMS (CI, $\left.\mathrm{NH}_{3}\right), m / z$ (relative intensity): 431 ([M+1] $\left.]^{+}, 10\right), 430$ (6), 429 (20), 401 (52), 386 (100).

HRMS $m / z$ calcd for $\mathrm{C}_{23} \mathrm{H}_{46} \mathrm{O}_{5} \mathrm{Si}+\mathrm{Na}$ : 453.3006; found: 453.3024 (ESI).

\section{(4S,5S,6S,8S,9S)-rel-5,9-Dihydroxy-4,6,8,10-tetramethylundecane-3,7-dione (136)}

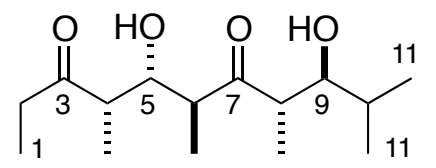

136

$\mathrm{FeCl}_{3} \cdot 6 \mathrm{H}_{2} \mathrm{O}(103 \mathrm{mg}, 0.382 \mathrm{mmol})$ was added to a stirred solution of aldol 135 (235 mg, $0.546 \mathrm{mmol})$ in acetone $(124 \mathrm{~mL})$ at room temperature. After $1 \mathrm{~h}$, the mixture was diluted with ethyl acetate and washed sequentially with saturated aq $\mathrm{NaHCO}_{3}$, water and brine, dried over $\mathrm{Na}_{2} \mathrm{SO}_{4}$, concentrated, and fractionated by FCC (30\% ethyl acetate in hexane) to provide the title compound (109 mg, 72\%).

IR $v_{\max } 3473 \mathrm{~cm}^{-1}$. 
${ }^{1} \mathbf{H}$ NMR $\left(500 \mathrm{MHz}, \mathrm{CDCl}_{3}\right) \delta 4.14(1 \mathrm{H}, \mathrm{d}, J=8.5 \mathrm{~Hz}, \mathrm{HC}-5), 3.55(1 \mathrm{H}, \mathrm{d}, J=4.5 \mathrm{~Hz}, \mathrm{HC}-9)$, 3.48 (iH, br s, HO), 2.89-2.75 (3H, m, HO, HC-6, HC-8), 2.70-2.61 (1H, m, HC-4), 2.61-2.44 (2H, m, HC-2), 1.84-1.72 (1H, m, HC-10), $1.15\left(3 \mathrm{H}, \mathrm{d}, J=7 \mathrm{~Hz}, \mathrm{H}_{3} \mathrm{CC}-4\right), 1.06(3 \mathrm{H}, \mathrm{d}, J=7$ $\left.\mathrm{Hz}, \mathrm{H}_{3} \mathrm{CC}-8\right), 1.03\left(3 \mathrm{H}, \mathrm{t}, J=7.5 \mathrm{~Hz}, \mathrm{H}_{3} \mathrm{C}-1\right), 1.01\left(3 \mathrm{H}, \mathrm{d}, J=7 \mathrm{~Hz}, \mathrm{H}_{3} \mathrm{CC}-6\right), 0.98(3 \mathrm{H}, \mathrm{d}, J=7$ $\left.\mathrm{Hz}, \mathrm{H}_{3} \mathrm{C}-11\right), 0.88\left(3 \mathrm{H}, \mathrm{d}, J=7 \mathrm{~Hz}, \mathrm{H}_{3} \mathrm{C}-11\right)$.

${ }^{13}$ C NMR (125 MHz, $\mathrm{CDCl}_{3}$ ) $\delta 218.8$ (s, C-7), 216.0 (s, C-3), 77.7 (d, C-9), 73.0 (d, C-5), 50.2 (d, C-8), 47.6 (d, C-6), 46.7 (d, C-4), 34.9 (t, C-2), 29.8 (d, C-10), 20.3 (q, C-11), 15.2 (q, C-11), 13.8 (q, $\mathrm{CH}_{3} \mathrm{C}-4$ or $\left.\mathrm{CH}_{3} \mathrm{C}-8\right), 13.7$ (q, $\mathrm{CH}_{3} \mathrm{C}-4$ or $\mathrm{CH}_{3} \mathrm{C}-8$ ), 9.7 (q, $\left.\mathrm{CH}_{3} \mathrm{C}-6\right), 7.8$ (q, C-1).

LRMS (CI, $\mathrm{NH}_{3}$ ), $m / z$ (relative intensity): 273 ([M+1] $\left.]^{+}, 52\right), 255$ (100), 237 (74), 183 (70), 165 (52), 86 (43), 57 (96).

HRMS $m / z$ calcd for $\mathrm{C}_{15} \mathrm{H}_{28} \mathrm{O}_{4}+\mathrm{H}: 273.2066$; found: 273.2069 (EI).

$((1 R, 3 R, 5 R, 7 R, 8 S, 9 R, 10 S)$-rel-3-Ethyl-8,9,10-trimethyl-5-(1-methyl)ethyl-2,4,6trioxatricyclo[3.3.1.1 $\left.{ }^{3,7}\right]$ decan-1-ol (121)

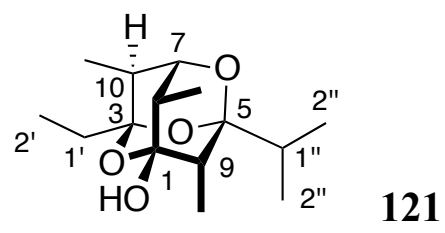

DMP (65 mg, $0.154 \mathrm{mmol})$ was added to a solution of diol $136(30 \mathrm{mg}, 0.11 \mathrm{mmol})$ in $\mathrm{CH}_{2} \mathrm{Cl}_{2}(8 \mathrm{~mL})$ at room temperature. After $1 \mathrm{~h}$, the mixture was diluted with ethyl acetate and washed sequentially with a 1:1 (v/v) mixture of saturated aq $\mathrm{NaHCO}_{3}$ and saturated aq $\mathrm{Na}_{2} \mathrm{SO}_{3}$, distilled water and brine, dried over $\mathrm{Na}_{2} \mathrm{SO}_{4}$, and concentrated to produce the crude hydroxytrione as a mixture of hemiacetal, enol and triketone tautomers $(28 \mathrm{mg})$. A solution of imidazole (24 mg, $0.36 \mathrm{mmol})$ and crude hydroxytriketone $(23 \mathrm{mg}, 0.084 \mathrm{mmol})$ in $\mathrm{CDCl}_{3}(0.6$ 
$\mathrm{mL}$; previously neutralized by passing through basic alumina) was heated to $40{ }^{\circ} \mathrm{C}$ (oil bath temperature). After 5 days (reaction monitored by ${ }^{1} \mathrm{H}$ NMR) the mixture was diluted with ethyl acetate and washed sequentially with $1 \%$ aq citric acid ('3), $\mathrm{NaHCO}_{3}$ and brine, dried over $\mathrm{Na}_{2} \mathrm{SO}_{4}$, and concentrated, and fractionated by preparative TLC ( $20 \%$ ethyl acetate in toluene) to give the title compound ( $8.5 \mathrm{mg}, 34 \%$ over 2 steps) in addition to other fractions that contained mixtures of retro-Claisen 128, dehydrated 127, and hemiacetal 124.

IR $v_{\max } 3423 \mathrm{~cm}^{-1}$.

${ }^{1} \mathbf{H}$ NMR $\left(500 \mathrm{MHz}, \mathrm{CDCl}_{3}\right) \delta 3.79(1 \mathrm{H}, \mathrm{d}, J=3 \mathrm{~Hz}, \mathrm{HC}-7), 2.63(1 \mathrm{H}, \mathrm{s}, \mathrm{HO}), 2.12-2.05(2 \mathrm{H}$, m, HC-9, HC-10), 2.02 (1H, br q, $J=7$ Hz, HC-8), 1.85 (1H, qq, $J=7,7$ Hz, HC-1"), 1.67-1.53 (2H, m, $\left.\mathrm{H}_{2} \mathrm{C}-1^{\prime}\right), 1.11\left(3 \mathrm{H}, \mathrm{d}, J=7 \mathrm{~Hz}, \mathrm{H}_{3} \mathrm{CC}-8\right), 1.00-0.87\left(15 \mathrm{H}, \mathrm{m}, \mathrm{H}_{3} \mathrm{CC}-10, \mathrm{H}_{3} \mathrm{CC}-8, \mathrm{H}_{3} \mathrm{C}-2\right.$ ', $\mathrm{H}_{3} \mathrm{C}-2$ '"×2).

${ }^{13}$ C NMR (125 MHz, $\mathrm{CDCl}_{3}$ ) $\delta 103.0$ (s, C-3), 102.9 (s, C-5), 97.9 (s, C-1), 78.0 (d, C-7), 36.7 (d, C-10), 35.9 (d, C-8), 34.9 (d, C-9), 32.6 (d, C-1"), 29.7 (t, C-1'), 15.2 (q, C-2"), 15.1 (q, C-2"), 13.3 (q, $\left.\mathrm{CH}_{3} \mathrm{C}-8\right), 12.6$ (q, $\left.\mathrm{CH}_{3} \mathrm{C}-10\right), 6.8$ (q, $\left.\mathrm{CH}_{3} \mathrm{C}-9\right), 6.6$ (q, C-2').

LRMS (CI, NH$)_{3}$ ), m/z (relative intensity): 271 ([M+1] $\left.]^{+}, 100\right), 253$ (99), 165 (66), 127 (46), 71 (58).

HRMS $m / z$ calcd for $\mathrm{C}_{15} \mathrm{H}_{26} \mathrm{O}_{4}+\mathrm{H}: 271.1909$; found: 271.1905 (CI, $\mathrm{NH}_{3}$ ). 


\section{$(3 S, 4 R, 6 S, 7 R, 8 S)$-rel-8-(2-Ethyl-1,3-dioxolan-2-yl)-3-hydroxy-2,4,6-trimethyl-7-}

(triethylsilyloxy)non-1-en-5-one (138)

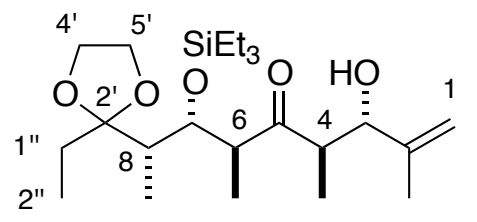

$\left(c-\mathrm{C}_{6} \mathrm{H}_{11}\right)_{2} \mathrm{BCl}(1 \mathrm{M}$ in hexane; $0.56 \mathrm{~mL}, 0.56 \mathrm{mmol})$ was added via syringe to a stirred solution of $\mathrm{Et}_{3} \mathrm{~N}(0.078 \mathrm{~mL}, 59 \mathrm{mg}, 0.58 \mathrm{mmol}) \mathrm{CH}_{2} \mathrm{Cl}_{2}(3 \mathrm{~mL})$ at $-78{ }^{\circ} \mathrm{C}$ under Ar. After $2 \mathrm{~min}$, a solution of ketone 109 (100 mg, $0.279 \mathrm{mmol})$ in $\mathrm{CH}_{2} \mathrm{Cl}_{2}(2 \mathrm{~mL})$ was added via syringe. After 2 $\mathrm{h}$, a solution of methacrolein $(0.048 \mathrm{~mL}, 39 \mathrm{mg}, 0.56 \mathrm{mmol}) \mathrm{CH}_{2} \mathrm{Cl}_{2}(0.5 \mathrm{~mL})$ was added dropwise via syringe. After $19.5 \mathrm{~h}$, the reaction was quenched by sequential addition of phosphate buffer(pH 7; $5 \mathrm{~mL}), \mathrm{MeOH}(1 \mathrm{~mL})$ and $30 \%$ aq $\mathrm{H}_{2} \mathrm{O}_{2}(1.5 \mathrm{~mL})$ with vigorous stirring. The mixture was warmed to $0{ }^{\circ} \mathrm{C}$ and after $10 \mathrm{~min}$, was diluted with ice-water and saturated aqueous $\mathrm{Na}_{2} \mathrm{SO}_{3}$ and extracted with $\mathrm{CH}_{2} \mathrm{Cl}_{2}$. The combined organic layers were died over $\mathrm{Na}_{2} \mathrm{SO}_{4}$ and concentrated to give the crude product whose ${ }^{1} \mathrm{H}$ NMR spectrum suggest the presence of a single adduct. Fractionation of the crude by FCC (10-20\% ethyl acetate in hexanes) afforded recovered 109 (49 $\mathrm{mg}, 49 \%$ ) and the title compound (51 mg, 40\%).

IR $v_{\max } 3470 \mathrm{~cm}^{-1}$.

${ }^{1}$ H NMR (500 MHz, $\mathrm{CDCl}_{3}$ ) $\delta 4.94$ (1H, br s, HC-1), 4.92 (1H, br s, HC-1), 4.30-4.22 (2H, m, HC-3, HC-7), 3.96-3.82 (4H, m, $\mathrm{H}_{2} \mathrm{C}-4{ }^{\prime}, \mathrm{H}_{2} \mathrm{C}-5$ '), 3.38 (1H, br s, HO), 3.08 (1H, dq, $J=4,7 \mathrm{~Hz}$, HC-6), 2.87 (1H, dq, $J=9,7$ Hz, HC-4), 2.04 (1H, br q, $J=7$ Hz, HC-8), 1.74 (3H, s, H ${ }_{3}$ CC-2), 1.71-1.53 (2H, m, $\left.\mathrm{H}_{2} \mathrm{C}-1 "\right), 1.07$ (3H, d, $\left.J=7 \mathrm{~Hz}, \mathrm{H}_{3} \mathrm{CC}-6\right), 0.99$ (9H, t, $\left.J=8 \mathrm{~Hz}, \mathrm{H}_{3} \mathrm{CCSi} \times 3\right)$, 
$0.94(3 \mathrm{H}, \mathrm{d}, J=7 \mathrm{~Hz}, \mathrm{HC}-9), 0.92\left(3 \mathrm{H}, \mathrm{d}, J=7 \mathrm{~Hz}, \mathrm{H}_{3} \mathrm{CC}-4\right), 0.83$ (3H, t, $\left.J=7.5 \mathrm{~Hz}, \mathrm{HC}-2 "\right)$, $0.65\left(6 \mathrm{H}\right.$, ap q, $\left.J=8 \mathrm{~Hz}, \mathrm{H}_{2} \mathrm{CSi} \times 3\right)$.

${ }^{13}$ C NMR (125 MHz, CDCl $)$ ) 215.9 (s, C-5), 144.2 (s, C-2), 114.6 (t, C-1), 114.3 (s, C-2'), 77.7 (d, C-3), 69.2 (d, C-7), 65.0 (t, C-4'), 64.8 (t, C-5'), 53.9 (d, C-6), 50.7 (d, C-4), 39.9 (d, C-8), 26.2 (t, C-1"), 16.6 (q, $\mathrm{CH}_{3} \mathrm{C}-2$ ), 14.7 (q, $\left.\mathrm{CH}_{3} \mathrm{C}-4\right), 11.11$ (q, $\left.\mathrm{CH}_{3} \mathrm{C}-6\right), 11.06$ (q, C-9), 7.4 (q, C2"), $7.2\left(\mathrm{q} \times 3, \mathrm{CH}_{3} \mathrm{CSi}\right), 5.5\left(\mathrm{t} \times 3, \mathrm{CH}_{2} \mathrm{Si}\right)$.

LRMS (CI, $\mathrm{NH}_{3}$ ), $m / z$ (relative intensity): 429 ([M+1] $\left.]^{+}, 13\right), 367$ (82), 302 (63), 297 (52), 285 (100), 273 (35), $199(58)$.

HRMS $m / z$ calcd for $\mathrm{C}_{23} \mathrm{H}_{44} \mathrm{O}_{5} \mathrm{Si}+\mathrm{H}: 429.3036$; found: $429.3029\left(\mathrm{CI}, \mathrm{NH}_{3}\right)$.

\section{$(4 S, 5 S, 6 S, 8 R, 9 S)-5,9-D i h y d r o x y-4,6,8,10-$ tetramethylundec-10-ene-3,7-dione (139)}

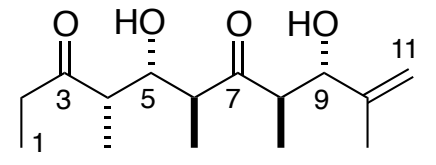

139

$\mathrm{FeCl}_{3} \cdot 6 \mathrm{H}_{2} \mathrm{O}(43 \mathrm{mg}, 0.158 \mathrm{mmol})$ was added to a stirred solution of aldol 138 (48 mg, $0.11 \mathrm{mmol}$ ) acetone $(26 \mathrm{~mL})$ and the mixture was heated under reflux. After $10 \mathrm{~min}$, the mixture was diluted with ethyl acetate and washed sequentially with saturated aq $\mathrm{NaHCO}_{3}$, water and brine, dried over $\mathrm{Na}_{2} \mathrm{SO}_{4}$, concentrated, and fractionated by PTLC (50\% ethyl acetate in hexane; developed twice) to provide the titled compound (21 $\mathrm{mg}, 52 \%)$.

IR $v_{\max } 3468 \mathrm{~cm}^{-1}$.

${ }^{1}$ H NMR (500 MHz, CDCl $) \delta 4.94$ (1H, br s, HC-11), 4.91 (1H, br s, HC-11), 4.19 (1H, d, $J=$ $9.5 \mathrm{~Hz}, \mathrm{HC}-9), 4.16(1 \mathrm{H}, \mathrm{dd}, J=3,8.5 \mathrm{~Hz}, \mathrm{HC}-5), 3.68$ (1H, br s, HOC-5), 3.15 (1H, br s, HOC- 
9), 3.04-2.92 (2H, m, HC-6, HC-8), 2.67 (1H, dq, $J=3,7 \mathrm{~Hz}, \mathrm{HC}-4), 2.62-2.45$ (2H, m, $\left.\mathrm{H}_{2} \mathrm{C}-2\right)$, $1.73\left(3 \mathrm{H}, \mathrm{s}, \mathrm{H}_{3} \mathrm{CC}-10\right), 1.17$ (3H, d, $\left.J=7 \mathrm{~Hz}, \mathrm{H}_{3} \mathrm{CC}-4\right), 1.04$ (3H, t, $\left.J=7.5 \mathrm{~Hz}, \mathrm{HC}-1,\right), 1.02$ $\left(3 \mathrm{H}, \mathrm{d}, J=7 \mathrm{~Hz}, \mathrm{H}_{3} \mathrm{CC}-6\right), 0.90\left(3 \mathrm{H}, \mathrm{d}, J=7 \mathrm{~Hz}, \mathrm{H}_{3} \mathrm{CC}-8\right)$.

${ }^{13}$ C NMR (125 MHz, $\mathrm{CDCl}_{3}$ ) $\delta 219.4$ (s, C-7), 215.9 (s, C-3), 144.4 (s, C-10), 114.8 (t, C-11), 80.0 (d, C-9), 74.4 (d, C-5), 50.4 (d, C-8), 49.4 (d, C-6), 47.0 (d, C-4), 34.9 (t, C-2), 16.5 (q, $\left.\mathrm{CH}_{3} \mathrm{C}-10\right), 14.2$ (q, $\mathrm{CH}_{3} \mathrm{C}-8$ ), 13.7 (q, $\mathrm{CH}_{3} \mathrm{C}-6$ ), 9.8 (q, $\mathrm{CH}_{3} \mathrm{C}-4$ ), 7.9 (q, C-1).

LRMS (CI, $\mathrm{NH}_{3}$ ), $m / z$ (relative intensity): 271 ([M+1] $\left.]^{+}, 51\right), 253$ (100), 201 (70), 200 (51), 183 (50), $171(22), 167$ (27), $153(18)$.

HRMS $m / z$ calcd for $\mathrm{C}_{15} \mathrm{H}_{26} \mathrm{O}_{4}+\mathrm{H}: 271.1909$; found: 271.1904 (CI, $\mathrm{NH}_{3}$ ).

(4S,6S)-rel-4,6-Dimethyl-3,7-dioxononan-5-yl 2-Methylpropenoate (141)

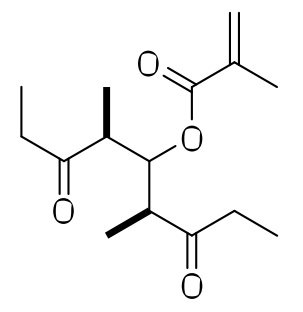

141

DMP (20 mg, $0.047 \mathrm{mmol})$ was added to a stirred solution of diol $139(9 \mathrm{mg}, 0.03 \mathrm{mmol})$ in $\mathrm{CH}_{2} \mathrm{Cl}_{2}(2.3 \mathrm{~mL})$. After $3 \mathrm{~h}$, the reaction was washed sequentially with a 1:1 (v/v) mixture of saturated aq solution of $\mathrm{NaHCO}_{3}$ and saturated aq $\mathrm{Na}_{2} \mathrm{SO}_{3}$ and brine, dried over $\mathrm{Na}_{2} \mathrm{SO}_{4}$, and concentrated to give the crude product $(11 \mathrm{mg})$ that was mixture of at least 4 major components by ${ }^{1} \mathrm{H}$ NMR. Imidazole (42 mg, $0.62 \mathrm{mmol}$ ) was added to a solution of the above crude (11 mg) in $\mathrm{CDCl}_{3}(0.6 \mathrm{~mL}$; previously passed through basic alumina) at room temperature. After $19.5 \mathrm{~h}$, the mixture was diluted in ethyl acetate, washed sequentially with $1 \%$ aq citric acid, saturated aq 
$\mathrm{NaHCO}_{3}$ and brine, dried over $\mathrm{Na}_{2} \mathrm{SO}_{4}$, and fractionated by PTLC (20\% ethyl acetate in hexanes; developed twice) to give the title compound ( $2.4 \mathrm{mg}, 24 \%)$.

IR $v_{\max } 1720 \mathrm{~cm}^{-1}$.

${ }^{1} \mathbf{H}$ NMR $\left(500 \mathrm{MHz}, \mathrm{CDCl}_{3}\right) \delta 6.04(1 \mathrm{H}, \mathrm{br} \mathrm{s}, \mathrm{HC}-3), 5.55$ (1H, br s, HC-3), 5.53 (1H, dd, $J=6$, 7 Hz, HC-5'), 2.97-2.83 (2H, m, HC-4', HC-6'), 2.71 (1H, dq, $J=18,7$ Hz, HC-2 or HC-8), 2.54$2.39\left(3 \mathrm{H}, \mathrm{m}, \mathrm{HC}-2, \mathrm{H}_{2} \mathrm{C}-8\right), 1.90\left(3 \mathrm{H}, \mathrm{s}, \mathrm{H}_{3} \mathrm{CC}-2\right), 1.13$ (3H, d, $J=7 \mathrm{~Hz}, \mathrm{HC} 3 \mathrm{C}-4{ }^{\prime}$ or $\left.\mathrm{H}_{3} \mathrm{CC}-6^{\prime}\right)$, $1.07\left(3 \mathrm{H}, \mathrm{d}, J=7 \mathrm{~Hz}, \mathrm{HC} 3 \mathrm{C}-4^{\prime}\right.$ or $\left.\mathrm{H}_{3} \mathrm{CC}-6^{\prime}\right), 1.04$ (3H, t, $J=7 \mathrm{~Hz}, \mathrm{HC} 3 \mathrm{C}-1^{\prime}$ or $\mathrm{H}_{3} \mathrm{CC}-9$ '), 1.01 $\left(3 \mathrm{H}, \mathrm{t}, J=7 \mathrm{~Hz}, \mathrm{HC} 3 \mathrm{C}-1^{\prime}\right.$ or $\left.\mathrm{H}_{3} \mathrm{CC}-9^{\prime}\right)$.

${ }^{13}$ C NMR $\left(125 \mathrm{MHz}, \mathrm{CDCl}_{3}\right) \delta 212.2\left(\mathrm{~s}, \mathrm{C}-3^{\prime}\right.$ or C-7'), 211.9 (s, C-3' or C-7'), 166.4 (s, C-1), 136.0 (s, C-2), 126.1 (t, C-3), 75.0 (d, C-5'), 48.2 (d, C-4' or C-6'), 46.8 (d, C-4' or C-6'), 35.4 (t, C-2' or C-8'), 35.1 (t, $\mathrm{C}-2^{\prime}$ or $\left.\mathrm{C}-8^{\prime}\right), 18.5$ (q, $\left.\mathrm{CH}_{3} \mathrm{C}-2\right), 13.2$ (q, $\mathrm{CH}_{3} \mathrm{C}-4^{\prime}$ or $\left.\mathrm{CH}_{3} \mathrm{C}-6^{\prime}\right), 11.6$ (q, $\mathrm{CH}_{3} \mathrm{C}-4^{\prime}$ or $\left.\mathrm{CH}_{3} \mathrm{C}-6^{\prime}\right), 7.9$ (q, $\mathrm{CH}_{3} \mathrm{C}-1^{\prime}$ or $\left.\mathrm{CH}_{3} \mathrm{C}-9^{\prime}\right), 7.8$ (q, $\mathrm{CH}_{3} \mathrm{C}-1^{\prime}$ or $\left.\mathrm{CH}_{3} \mathrm{C}-9^{\prime}\right)$.

LRMS (CI, $\mathrm{NH}_{3}$ ), m/z (relative intensity): 269 ([M+1] $\left.]^{+}, 13\right), 183$ (61), 165 (100), 139 (18), 126 (14), 125 (18), 69 (44), 57 (64).

HRMS $m / z$ calcd for $\mathrm{C}_{15} \mathrm{H}_{24} \mathrm{O}_{4}+\mathrm{H}: 269.1753$; found: $269.1749\left(\mathrm{CI}, \mathrm{NH}_{3}\right)$. 
(2S,3R,4S,8S)-2-(2-Ethyl-1,3-dioxolan-2-yl)-3-triethylsilyloxy-7-hydroxy-4,6,8-trimethyl-9(phenylmethoxy)nonan-5-one (142).

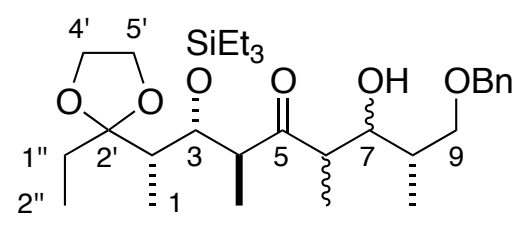

142

LHMDS (1 M in THF; $0.21 \mathrm{~mL}, 0.21 \mathrm{mmol})$ was added to a solution of (+)-109 (50 $\mathrm{mg}, 0.14$ $\mathrm{mmol})$ in $\mathrm{THF}(0.7 \mathrm{~mL})$ at $-50^{\circ} \mathrm{C}$. After $1 \mathrm{~h}$, the reaction mixture was cooled to $-78{ }^{\circ} \mathrm{C}$ and a solution of freshly prepared $(S)-29(28 \mathrm{mg}, 0.16 \mathrm{mmol})$ in THF $(0.7 \mathrm{~mL})$ was added slowly via syringe. After $1 \mathrm{~h}$, the reaction was quenched by addition of aq. phosphate buffer $(\mathrm{pH}=7)$ and the mixture was extracted with ethyl acetate. The combined organic layers were dried over $\mathrm{Na}_{2} \mathrm{SO}_{4}$, concentrated, and fractionated by $\mathrm{FCC}$ (2-100\% ethyl acetate in $\mathrm{CH}_{2} \mathrm{Cl}_{2}$ ) to give recovered (+)-109 (8 $\mathrm{mg}, 16 \%)$ and the title compound as a ca. 43:25:18:15 mixture of diastereomers $(60 \mathrm{mg}, 80 \%)$.

IR $v_{\max }: 3513,1697 \mathrm{~cm}^{-1}$

${ }^{1} \mathbf{H}$ NMR (500 MHz, $\left.\mathrm{CDCl}_{3}\right)$ ঠ: 7.38-7.24 (5H, m, Ph), 4.60-4.43 (2H, m, $\left.\mathrm{H}_{2} \mathrm{CPh}\right), 4.29(0.25 \mathrm{H}$, $\mathrm{dd}, J=1,5 \mathrm{~Hz}, \mathrm{HC}-3), 4.25(0.60 \mathrm{H}$, ap dd $J=1,5 \mathrm{~Hz}, \mathrm{HC}-3), 4.23(0.18 \mathrm{H}, \mathrm{dd}, J=1.5,5 \mathrm{~Hz}$, HC-3), $4.01(0.15 \mathrm{H}$, br d, $J=9.5 \mathrm{~Hz}, \mathrm{HC}-7), 3.93(0.18 \mathrm{H}$, br d, $J=10 \mathrm{~Hz}, \mathrm{HC}-7), 3.91-3.72$ (4.5H, m, $\mathrm{H}_{2} \mathrm{C}-4$ ', $\mathrm{H}_{2} \mathrm{C}-5$ ', $\left.\mathrm{HC}-7\right), 3.69-3.39$ (2.2H, m, HC-7, $\left.\mathrm{H}_{2} \mathrm{C}-9\right), 3.21(0.25 \mathrm{H}, \mathrm{d}, J=7 \mathrm{~Hz}$, HO), 3.12-2.89 (1.7H, m, HC-4, HC-6), 2.85 (0.15H, br q, $J=7.5$ Hz, HC-6), $2.83(0.43 \mathrm{H}, \mathrm{d}, J=$ $2 \mathrm{~Hz}, \mathrm{HO}), 2.79(0.18 \mathrm{H}, \mathrm{dq}, J=1.5,7.5 \mathrm{~Hz}, \mathrm{HC}-6), 2.02(0.15 \mathrm{H}, \mathrm{dq}, J=1,7 \mathrm{~Hz}, \mathrm{HC}-2), 1.99-$ 1.75 (1.8H, m, HC-2, HC-8), 1.75-1.53 (2H, m, $\left.\mathrm{H}_{2} \mathrm{C}-1 "\right), 1.15\left(1.8 \mathrm{H}\right.$, br d, $\left.J=7.5 \mathrm{~Hz}, \mathrm{H}_{3} \mathrm{CC}-6\right)$, 1.10-0.90 (19.2H, m), 0.87-0.80 (3H, m, $\left.\mathrm{H}_{3} \mathrm{C}-2 "\right), 0.68-0.58\left(6 \mathrm{H}, \mathrm{m}, \mathrm{H}_{2} \mathrm{CSi} \times 3\right)$ 
${ }^{13}$ C NMR (125 MHz, $\mathrm{CDCl}_{3}$ ) $\delta$ (major diastereomer*): 218.1, 216.8, 216.5, 216.2*, 138.9, $138.8,138.3^{*}, 138.2,128.62,128.60^{*}, 128.53,128.46,127.9,127.8^{*}, 127,78,127,74,127.69^{*}$, $127.63,114.2,113.99,113.91 *, 78.7,74.7^{*}, 74.6^{*}, 74.3,73.69,73.55,73.48,73.44,72.6,72.4$ $71.9,70.4,70.2^{*}, 69.51,69.45,65.2^{*}, 65.1,64.95^{*}, 64.93,64.8,55.7,53.7 *, 53.6,52.5,50.6$, $49.7,49.1^{*}, 47.2,40.8^{*}, 40.7,40.5,40.0,36.3^{*}, 36.2,35.6,34.9,26.5^{*}, 26.3,15.7,14.0,13.8$, $13.3,12.9^{*}, 11.8^{*}, 11.4,10.99,10.95,10.93,10.92,10.8^{*}, 10.7 *, 9.4,8.9,7.4,7.31,7.26^{*}, 7.21$, $7.18,5.55,5.48 *, 5.43$

LRMS (CI, $\left.\mathrm{NH}_{3}\right), m / z$ (relative intensity): $537\left([\mathrm{M}+1]^{+}, 1\right), 359$ (36), 227 (37), 196 (23), 179 (10), $101(100), 91(23)$

HRMS $m / z$ calcd for $\mathrm{C}_{30} \mathrm{H}_{52} \mathrm{O}_{6} \mathrm{Si}+\mathrm{H}: 537.3611$; found: $537.3592\left(\mathrm{CI}, \mathrm{NH}_{3}\right)$

$(2 R, 3 S, 5 S, 6 S)-T e t r a h y d r o-2-h y d r o x y-3,5-d i m e t h y l-6-((S)-1-m e t h y l-2-o x o b u t y l)-2-((S)-1-$ methyl-2-(phenylmethoxy)ethyl)-tetrahydro-4H-pyran-4-one (134).
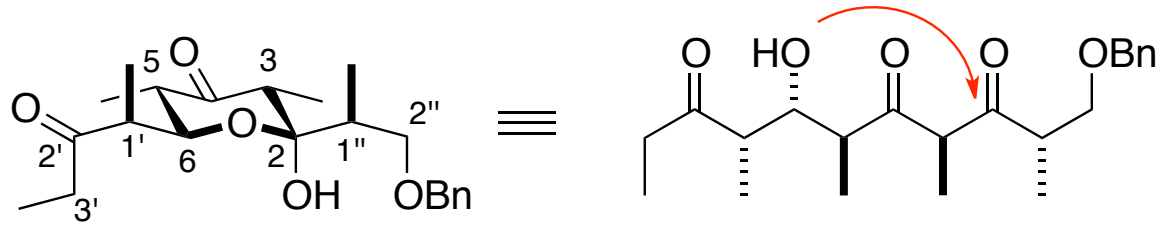

$\mathrm{FeCl}_{3} \cdot 6 \mathrm{H}_{2} \mathrm{O}(10.5 \mathrm{mg}, 0.039 \mathrm{mmol})$ was added to a stirred solution of aldol adducts $142(20 \mathrm{mg}$, $0.037 \mathrm{mmol})$ in acetone $(1.3 \mathrm{~mL})$ at room temperature. After $1 \mathrm{~h}$, the mixture was diluted with ethyl acetate and washed sequentially with saturated aq $\mathrm{NaHCO}_{3}, \mathrm{H}_{2} \mathrm{O}$ and brine, dried over $\mathrm{Na}_{2} \mathrm{SO}_{4}$, and concentrated. The residue was taken up in $\mathrm{CH}_{2} \mathrm{Cl}_{2}(2.6 \mathrm{~mL})$ and DMP (16 mg, 0.038 mmol) was added to the stirred solution. After $3 \mathrm{~h}$, the reaction was washed sequentially with a 1:1 (v/v) mixture of saturated aq $\mathrm{NaHCO}_{3}$ and saturated aq $\mathrm{Na}_{2} \mathrm{SO}_{3}, \mathrm{H}_{2} \mathrm{O}$ and brine, dried over $\mathrm{Na}_{2} \mathrm{SO}_{4}$, and concentrated. The residue was dissolved in a solution of imidazole $(22 \mathrm{mg}, 0.32$ 
mmol) in $\mathrm{CDCl}_{3}\left(0.6 \mathrm{~mL}\right.$; previously passed over basic alumina) and heated at $40{ }^{\circ} \mathrm{C}$ in an $\mathrm{NMR}$ tube. After $19 \mathrm{~h}$, the mixture was diluted in ethyl acetate, washed sequentially with citric acid $1 \%$, saturated aq $\mathrm{NaHCO}_{3}$ and brine, dried over $\mathrm{Na}_{2} \mathrm{SO}_{4}$, concentrated, and fractionated by PTLC (20\% ethyl acetate in hexanes; multiple elutions) to afford of the titled compound (4.5 mg, $32 \%$ over 3 steps $) .[\alpha]_{\mathrm{D}}+30\left(c 0.4, \mathrm{CHCl}_{3}\right)$

IR $v_{\max }: 3408,1719 \mathrm{~cm}^{-1}$

${ }^{1} \mathbf{H}$ NMR (500 MHz, $\left.\mathrm{CDCl}_{3}\right) \delta: 5.58(1 \mathrm{H}, \mathrm{d}, J=2.5 \mathrm{~Hz}, \mathrm{HO}), 4.51(1 \mathrm{H}, \mathrm{d}, J=11.5 \mathrm{~Hz}, \mathrm{HCPh})$, $4.45(1 \mathrm{H}, \mathrm{dd}, J=2.5,10.5 \mathrm{~Hz}, \mathrm{HC}-6), 4.34(1 \mathrm{H}, \mathrm{d}, J=11.5 \mathrm{~Hz}, \mathrm{HCPh}), 3.70(1 \mathrm{H}, \mathrm{dd}, J=9,11$ Hz, HC-2"), 3.42 (1H, dd, $J=4,9$ Hz, HC-2"), 2.73 (1H, dq, $J=2.5,7$ Hz, HC-1'), 2.61 (1H, br q, $J=6.5 \mathrm{~Hz}, \mathrm{HC}-3), 2.57-2.42\left(3 \mathrm{H}, \mathrm{m}, \mathrm{H}_{2} \mathrm{C}-3\right.$ ', $\left.\mathrm{HC}-5\right), 2.22\left(1 \mathrm{H}, \mathrm{ddq}, J=4,9,7 \mathrm{~Hz}, \mathrm{HC}-1^{\prime \prime}\right)$, $1.18\left(3 \mathrm{H}, \mathrm{d}, J=7 \mathrm{~Hz}, \mathrm{H}_{3} \mathrm{CC}-1^{\prime}\right), 1.04\left(3 \mathrm{H}, \mathrm{t}, J=7.5 \mathrm{~Hz}, \mathrm{H}_{3} \mathrm{C}-4^{\prime}\right), 104\left(3 \mathrm{H}, \mathrm{d}, J=6.5 \mathrm{~Hz}, \mathrm{H}_{3} \mathrm{CC}-\right.$ 3), $103\left(3 \mathrm{H}, \mathrm{d}, J=7 \mathrm{~Hz}, \mathrm{H}_{3} \mathrm{CC}-5\right), 0.88\left(3 \mathrm{H}, \mathrm{d}, J=7 \mathrm{~Hz}, \mathrm{H}_{3} \mathrm{CC}-1 "\right)$

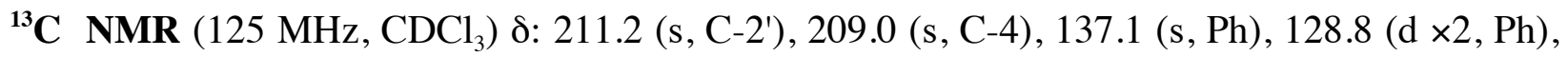
128.2 (d, Ph), 127.8 (d ×2, Ph), 104.0 (s, C-2), 74.4 (d, C-6), 73.8 (t, $\left.\mathrm{CH}_{2} \mathrm{Ph}\right), 73.4$ (t, C-2"), 51.1 (d, C-3), 48.0 (d, C-1'), 46.6 (d, C-5), 38.4 (d, C-1"), 33.3 (t, C-3'), 12.3 (q, $\left.\mathrm{CH}_{3} \mathrm{C}-1^{\prime \prime}\right), 9.4$ (q, $\left.\mathrm{CH}_{3} \mathrm{C}-5\right), 8.29$ (q, C-4' or $\left.\mathrm{CH}_{3} \mathrm{C}-3\right), 8.29$ (q, C-4' or $\left.\mathrm{CH}_{3} \mathrm{C}-3\right), 7.8$ (q, $\mathrm{CH}_{3} \mathrm{C}-1^{\prime}$ )

LRMS (CI, $\left.\mathrm{NH}_{3}\right), m / z$ (relative intensity): $394\left([\mathrm{M}+18]^{+}, 26\right), 377\left([\mathrm{M}+1]^{+}, 17\right), 360(27), 359$ (93), 212 (21), 195 (26), 193 (39), 183 (82), 108 (20), 91 (100)

HRMS $m / z$ calcd for $\mathrm{C}_{22} \mathrm{H}_{32} \mathrm{O}_{5}+\mathrm{NH}_{4}$ : 394.2593; found: $394.2603\left(\mathrm{CI}, \mathrm{NH}_{3}\right)$. 
$(2 R, 3 S, 4 R, 8 S)$-2-(2-Ethyl-1,3-dioxolan-2-yl)-3-triethylsilyloxy-7-hydroxy-4,6,8-trimethyl-9(phenylmethoxy)nonan-5-one (149).

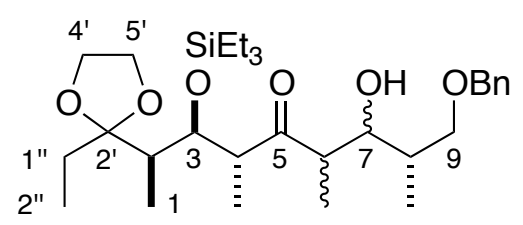

A solution of freshly prepared LDA $(0.17 \mathrm{M}$ in THF; $9.5 \mathrm{~mL}, 1.6 \mathrm{mmol})$ at $0{ }^{\circ} \mathrm{C}$ was added via cannula to a stirred solution of (-)-109 (ent-109) $(527 \mathrm{mg}, 1.47 \mathrm{mmol})$ in dry THF (26 mL) at $78{ }^{\circ} \mathrm{C}$ under argon. After $15 \mathrm{~min}, \mathrm{Ti}\left(\mathrm{O}^{i} \mathrm{Pr}\right)_{4}(0.99 \mathrm{~mL}, 0.92 \mathrm{~g}, 3.2 \mathrm{mmol})$ was added. The reaction mixture was stirred for $10 \mathrm{~min}$ at $-78{ }^{\circ} \mathrm{C}, 30 \mathrm{~min}$ at $-50{ }^{\circ} \mathrm{C}$, and finally $5 \mathrm{~min}$ at $-78{ }^{\circ} \mathrm{C}$. A solution of freshly prepared $(S)-29(283 \mathrm{mg}, 1.59 \mathrm{mmol})$ in THF $(10 \mathrm{~mL})$ was added over $10 \mathrm{~min}$ via syringe. After $19 \mathrm{~h}$, the reaction was quenched by addition of $\mathrm{H}_{2} \mathrm{O}(14 \mathrm{~mL})$, and the mixture was extracted with ethyl acetate. The combined organic layers were dried over $\mathrm{Na}_{2} \mathrm{SO}_{4}$, concentrated, and fractionated by FCC (5\% ethyl acetate in $\mathrm{CH}_{2} \mathrm{Cl}_{2}$ ) to give recovered ent-109 (85 mg, 16\%) and a 82:14:4 mixture of aldol adducts (646 mg, 81\%).

$[\alpha]_{\mathrm{D}}-59\left(c 1.0, \mathrm{CHCl}_{3}\right)$

IR $v_{\text {max }}: 3508,1699 \mathrm{~cm}^{-1}$

${ }^{1} \mathbf{H}$ NMR $\left(500 \mathrm{MHz}, \mathrm{CDCl}_{3}\right) \delta$ (major diastereomer only): 7.39-7.21 (5H, m, Ph), 4.52-4.48 (2H, m, $\left.\mathrm{CH}_{2} \mathrm{Ph}\right), 4.17(1 \mathrm{H}, \mathrm{dd}, J=1.5,4 \mathrm{~Hz}, \mathrm{HC}-3), 3.93(1 \mathrm{H}, \mathrm{ddd}, J=2,3,7 \mathrm{~Hz}, \mathrm{HC}-7), 3.89-3.71$ (4H, m, $\mathrm{H}_{2} \mathrm{C}-4$ ', $\mathrm{H}_{2} \mathrm{C}-5$ ') , 3.43-3.37 (2H, dd, $\left.J=5,2.5 \mathrm{~Hz}, \mathrm{H}_{2} \mathrm{C}-9\right), 3.36(1 \mathrm{H}, \mathrm{d}, J=2 \mathrm{~Hz}, \mathrm{HO})$, $3.04(1 \mathrm{H}, \mathrm{dq}, J=4,7 \mathrm{~Hz}, \mathrm{HC}-4), 2.88(1 \mathrm{H}, \mathrm{dq}, J=3,7 \mathrm{~Hz}, \mathrm{HC}-6), 1.98(1 \mathrm{H}, \mathrm{dq}, J=1.5,7 \mathrm{~Hz}$, HC-2), 1.94-1.85 (1H, m, HC-8), 1.66 (1H, dq, $J=14.5,7.5 \mathrm{~Hz}, \mathrm{HC}-1 "), 1.56(1 \mathrm{H}, \mathrm{dq}, J=14.5$, $7.5 \mathrm{~Hz}, \mathrm{HC}-1 "), 1.17\left(3 \mathrm{H}, \mathrm{d}, J=7 \mathrm{~Hz}, \mathrm{H}_{3} \mathrm{CC}-6\right), 1.09\left(3 \mathrm{H}, \mathrm{d}, J=7 \mathrm{~Hz}, \mathrm{H}_{3} \mathrm{CC}-8\right), 1.04(3 \mathrm{H}, \mathrm{d}, J=$ 
$\left.7 \mathrm{~Hz}, \mathrm{H}_{3} \mathrm{CC}-4\right), 0.96\left(9 \mathrm{H}, \mathrm{t}, J=8 \mathrm{~Hz}, \mathrm{H}_{3} \mathrm{CCSi} \times 3\right), 0.93\left(3 \mathrm{H}, \mathrm{d}, J=7 \mathrm{~Hz}, \mathrm{H}_{3} \mathrm{C}-1\right), 0.82(3 \mathrm{H}, \mathrm{t}, J=$ $\left.7.5 \mathrm{~Hz}, \mathrm{H}_{3} \mathrm{C}-2 "\right), 0.61\left(6 \mathrm{H}\right.$, ap q, $\left.J=8 \mathrm{~Hz}, \mathrm{H}_{2} \mathrm{CSi} \times 3\right)$

${ }^{13} \mathbf{C}$ NMR (125 MHz, $\mathrm{CDCl}_{3}$ ) $\delta$ (major diastereomer only): 217.5 (s, C-5), 138.5 (s, Ph), 128.5 $(\mathrm{d} \times 2, \mathrm{Ph}), 127.8(\mathrm{~d}, \mathrm{Ph}), 127.6(\mathrm{~d} \times 2, \mathrm{Ph}), 114.0\left(\mathrm{~s}, \mathrm{C}-2\right.$ '), $73.9(\mathrm{t}, \mathrm{C}-9), 73.5\left(\mathrm{t}, \mathrm{CH}_{2} \mathrm{Ph}\right), 73.1(\mathrm{~d}$, C-7), 70.1 (d, C-3), 65.2 (t, C-4' or C-5'), 64.9 (t, C-5' or C-4'), 52.6 (d, C-4), 48.9 (d, C-6), 40.4 (d, C-2), 36.3 (d, C-8), 26.2 (t, C-1"), 14.0 (q, $\left.\mathrm{CH}_{3} \mathrm{C}-8\right), 11.2$ (q, C-1 or $\left.\mathrm{CH}_{3} \mathrm{C}-4\right), 11.1$ (q, C-1 or $\left.\mathrm{CH}_{3} \mathrm{C}-4\right), 10.6\left(\mathrm{q}, \mathrm{CH}_{3} \mathrm{C}-6\right), 7.3$ (q, C-2"), $7.2\left(\mathrm{q} \times 3, \mathrm{CH}_{3} \mathrm{CSi}\right), 5.5\left(\mathrm{t} \times 3, \mathrm{CH}_{2} \mathrm{Si}\right)$

LRMS (EI), $m / z$ (relative intensity): 507 ([M-29] $\left.]^{+}, 20\right), 378$ (16), 377 (48), 364 (11), 349 (12), 330 (27), $329(100)$

HRMS $\mathrm{m} / \mathrm{z}$ calcd for $\mathrm{C}_{30} \mathrm{H}_{52} \mathrm{O}_{6} \mathrm{Si}+\mathrm{H}: 537.3611$; found: $537.3591\left(\mathrm{CI}, \mathrm{NH}_{3}\right)$.

$(2 R, 3 S, 4 R, 8 S)$-2-(2-Ethyl-1,3-dioxolan-2-yl)-3-triethylsilyloxy-7-hydroxy-4,6,8-trimethyl-9(phenylmethoxy)nonan-5-one (149).

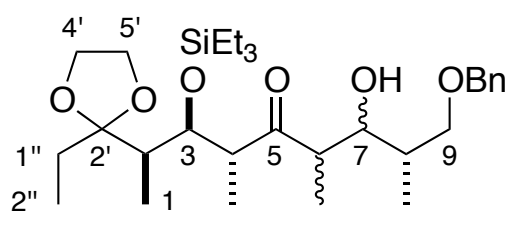

LHMDS (1 M in THF; $2.2 \mathrm{~mL}, 2.2 \mathrm{mmol})$ was added to a solution of (-)-109 (1.31 g, 3.65 mmol) in THF $(31 \mathrm{~mL})$ at $-50{ }^{\circ} \mathrm{C}$. After $1 \mathrm{~h}$, the reaction mixture was cooled to $-78{ }^{\circ} \mathrm{C}$ and a solution of freshly prepared $(S)-\mathbf{2 9}(677 \mathrm{mg}, 3.80 \mathrm{mmol})$ in THF $(2 \mathrm{~mL})$ was added slowly via syringe over $5 \mathrm{~min}$. After $1 \mathrm{~h}$, the reaction was quenched by addition of aq phosphate buffer $(\mathrm{pH}=7)$ and the mixture was extracted with ethyl acetate. The combined organic layers were dried over $\mathrm{Na}_{2} \mathrm{SO}_{4}$, concentrated, and fractionated by FCC ( $2 \%$ ethyl acetate in $\mathrm{CH}_{2} \mathrm{Cl}_{2}$ ) to give 
recovered 29 (110 $\mathrm{mg}, 16 \%)$, ent-109 (262 $\mathrm{mg}, 20 \%)$, and a 73:10:9:8 mixture of aldol adducts $(1.51 \mathrm{mg}, 77 \%) \cdot[\alpha]_{\mathrm{D}}-51\left(c 0.95, \mathrm{CHCl}_{3}\right)$

IR $v_{\max }: 3491,1706 \mathrm{~cm}^{-1}$

${ }^{1} \mathbf{H}$ NMR (500 MHz, $\left.\mathrm{CDCl}_{3}\right) \delta$ (major diastereomer only): 7.39-7.23 (5H, m, Ph), 4.57-4.47 (2H, m, $\left.\mathrm{H}_{2} \mathrm{CPh}\right), 4.25(1 \mathrm{H}, \mathrm{dd}, J=1.5,5 \mathrm{~Hz}, \mathrm{HC}-3), 3.92(1 \mathrm{H}, \mathrm{ddd}, J=2,2,9 \mathrm{~Hz}, \mathrm{HC}-7), 3.90-3.73$ (4H, m, $\left.\mathrm{H}_{2} \mathrm{C}-4^{\prime}, \mathrm{H}_{2} \mathrm{C}-5^{\prime}\right), 3.62$ (1H, dd, $\left.J=5,9 \mathrm{~Hz}, \mathrm{HC}-9\right) 3.58$ (1H, dd, $\left.J=7,9 \mathrm{~Hz}, \mathrm{HC}-9\right), 3.51$ $(1 \mathrm{H}, \mathrm{d}, J=2 \mathrm{~Hz}, \mathrm{HO}), 3.11(1 \mathrm{H}, \mathrm{d} 7, J=5,7 \mathrm{~Hz}, \mathrm{HC}-4), 2.85(1 \mathrm{H}, \mathrm{dq}, J=2,7 \mathrm{~Hz}, \mathrm{HC}-6), 2.00-$ $1.90(1 \mathrm{H}, \mathrm{m}, \mathrm{HC}-8), 1.87(1 \mathrm{H}, \mathrm{dq}, J=1.5,7 \mathrm{~Hz}, \mathrm{HC}-2), 1.68(1 \mathrm{H}, \mathrm{dq}, J=14.5,7.5 \mathrm{~Hz}, \mathrm{HC}-1 ")$, $1.59(1 \mathrm{H}, \mathrm{dq}, J=14.5,7.5 \mathrm{~Hz}, \mathrm{HC}-1 "), 1.06\left(3 \mathrm{H}, \mathrm{d}, J=7 \mathrm{~Hz}, \mathrm{H}_{3} \mathrm{CC}-6\right), 1.05(3 \mathrm{H}, \mathrm{d}, J=7 \mathrm{~Hz}$, $\left.\mathrm{H}_{3} \mathrm{CC}-4\right), 0.97\left(9 \mathrm{H}, \mathrm{t}, J=8 \mathrm{~Hz}, \mathrm{H}_{3} \mathrm{CCSi} \times 3\right), 0.93\left(3 \mathrm{H}, \mathrm{d}, J=7 \mathrm{~Hz}, \mathrm{H}_{3} \mathrm{C}-1\right), 0.92(3 \mathrm{H}, \mathrm{d}, J=7$ $\left.\mathrm{Hz}, \mathrm{H}_{3} \mathrm{CC}-8\right), 0.83\left(3 \mathrm{H}, \mathrm{t}, J=7.5 \mathrm{~Hz}, \mathrm{H}_{3} \mathrm{C}-2 "\right), 0.63\left(6 \mathrm{H}, \mathrm{q}, J=8 \mathrm{~Hz}, \mathrm{H}_{2} \mathrm{CSi} \times 3\right)$

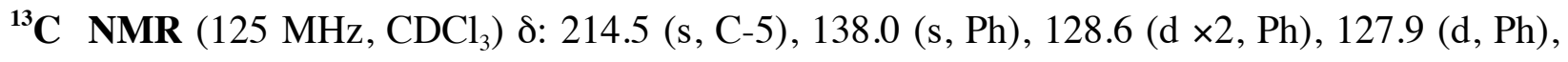
$127.8(\mathrm{~d} \times 2, \mathrm{Ph}), 114.0(\mathrm{~s}, \mathrm{C}-2$ '), $75.6(\mathrm{~d}, \mathrm{C}-7), 75.2(\mathrm{t}, \mathrm{C}-9), 73.7$ (d, C-3), $65.2(\mathrm{t}, \mathrm{C}-4$ ' or C-5'), 64.9 (t, C-5' or C-4'), 51.9 (d, C-4), 48.5 (d, C-6), 40.7 (d, C-2), 36.4 (d, C-8), 26.3 (t, C-1"), 13.9 (q, $\left.\mathrm{CH}_{3} \mathrm{C}-8\right), 11.1$ (q, $\left.\mathrm{CH}_{3} \mathrm{C}-4\right), 10.8$ (q, C-1), $7.7\left(\mathrm{q}, \mathrm{CH}_{3} \mathrm{C}-6\right), 7.2$ (q ×3, $\left.\mathrm{CH}_{3} \mathrm{CSi}\right), 7.2$ (q, C-2"), $5.5\left(\mathrm{t} \times 3, \mathrm{CH}_{2} \mathrm{Si}\right)$

LRMS (CI, $\left.\mathrm{NH}_{3}\right), m / z$ (relative intensity): 537 ([M+1] $\left.]^{+}, 21\right), 476$ (36), 475 (100), 424 (21), 405 (42), 387 (32), 379 (17), 377 (11)

HRMS $\mathrm{m} / \mathrm{z}$ calcd for $\mathrm{C}_{30} \mathrm{H}_{52} \mathrm{O}_{6} \mathrm{Si}+\mathrm{H}$ : 537.3611; found: $537.3601\left(\mathrm{CI}, \mathrm{NH}_{3}\right)$. 

(150).

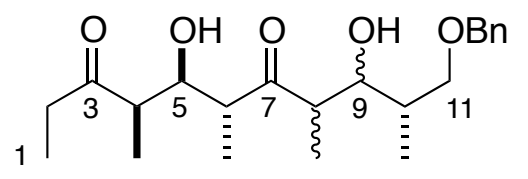

150

$\mathrm{FeCl}_{3} \cdot 6 \mathrm{H}_{2} \mathrm{O}$ (43 mg, $0.16 \mathrm{mmol}$ ) was added to a stirred solution of aldol adducts 149 (coming from the reaction with $\mathrm{Ti}$ 'ate' enolate) $(123 \mathrm{mg}, 0.230 \mathrm{mmol})$ in acetone $(52 \mathrm{~mL})$ at room temperature. After $1.5 \mathrm{~h}$, the mixture was diluted with ethyl acetate and washed sequentially with saturated aq $\mathrm{NaHCO}_{3}, \mathrm{H}_{2} \mathrm{O}$ and brine, dried over $\mathrm{Na}_{2} \mathrm{SO}_{4}$, concentrated, and fractionated by FCC (30\% ethyl acetate in hexane) to afford the titled compound (80 mg, 92\%). Usually, the crude from this reaction mixture was used in the following reaction without further purification. $[\alpha]_{D}-$ $20\left(c 0.05, \mathrm{CHCl}_{3}\right)$

IR $v_{\max }: 3489,1709 \mathrm{~cm}^{-1}$

${ }^{1} \mathbf{H}$ NMR (500 MHz, $\left.\mathrm{CDCl}_{3}\right) \delta$ (major diastereomer only): 7.39-7.24 (5H, m, Ph), 4.50 (1H, d, $J$ $=12, \mathrm{CHPh}), 4.48(1 \mathrm{H}, \mathrm{d}, J=12 \mathrm{~Hz}, \mathrm{CHPh}), 4.09(1 \mathrm{H}, \mathrm{ddd}, J=2.5,3,9 \mathrm{~Hz}, \mathrm{HC}-5), 4.05(1 \mathrm{H}$, ddd, $J=3,4.5,7 \mathrm{~Hz}, \mathrm{HC}-9), 3.48(1 \mathrm{H}, \mathrm{dd}, J=4.5,9.5 \mathrm{~Hz}, \mathrm{HC}-11), 3.43(1 \mathrm{H}, \mathrm{dd}, J=4.5,9.5 \mathrm{~Hz}$, HC-11), $3.38(1 \mathrm{H}, \mathrm{d}, J=3 \mathrm{~Hz}, \mathrm{HOC}-5), 3.08(1 \mathrm{H}, \mathrm{d}, J=3 \mathrm{~Hz}, \mathrm{HOC}-9), 2.89(1 \mathrm{H}, \mathrm{dq}, J=9,7$ Hz, HC-6), $2.85(1 \mathrm{H},, J=4.5,7 \mathrm{~Hz}, \mathrm{HC}-8), 2.65(1 \mathrm{H}, \mathrm{dq}, J=2.5,7 \mathrm{~Hz}, \mathrm{HC}-4), 2.56(1 \mathrm{H}, \mathrm{dq}, J=$ $18,7.5 \mathrm{~Hz}, \mathrm{HC}-2), 2.50(1 \mathrm{H}, \mathrm{dq}, J=18,7.5 \mathrm{~Hz}, \mathrm{HC}-2), 1.96-1.84(1 \mathrm{H}, \mathrm{m}, \mathrm{HC}-10), 1.13(3 \mathrm{H}, \mathrm{d}, J$ $\left.=7 \mathrm{~Hz}, \mathrm{H}_{3} \mathrm{CC}-4\right), 1.11\left(3 \mathrm{H}, \mathrm{d}, J=7 \mathrm{~Hz}, \mathrm{H}_{3} \mathrm{CC}-8\right), 1.09\left(3 \mathrm{H}, \mathrm{d}, J=7 \mathrm{~Hz}, \mathrm{H}_{3} \mathrm{CC}-10\right), 1.05(3 \mathrm{H}, \mathrm{t}$, $\left.J=7.5 \mathrm{~Hz}, \mathrm{H}_{3} \mathrm{C}-1\right), 0.94\left(3 \mathrm{H}, \mathrm{d}, J=7 \mathrm{~Hz}, \mathrm{H}_{3} \mathrm{C}-6\right)$

${ }^{13} \mathbf{C}$ NMR (125 MHz, $\mathrm{CDCl}_{3}$ ) $\delta$ (major diastereomer only): 217.9 (s, C-7), 216.5 (s, C-3), 138.6 (s, Ph), $128.6(\mathrm{~d} \times 2, \mathrm{Ph}), 127.8(\mathrm{~d}, \mathrm{Ph}), 127.7(\mathrm{~d} \times 2, \mathrm{Ph}), 74.3(\mathrm{t}, \mathrm{C}-11), 73.6(\mathrm{~d}, \mathrm{C}-5), 73.5(\mathrm{t}$, 
$\left.\mathrm{CH}_{2} \mathrm{Ph}\right), 73.0$ (d, C-9), 50.5 (d, C-8), $46.2(\mathrm{~d} \times 2, \mathrm{C}-4, \mathrm{C}-6), 36.1$ (d, C-10), $35.0(\mathrm{t}, \mathrm{C}-2), 14.0(\mathrm{q}$, $\left.\mathrm{CH}_{3} \mathrm{C}-6\right), 13.6$ (q, $\left.\mathrm{CH}_{3} \mathrm{C}-10\right), 10.0$ (q, $\left.\mathrm{CH}_{3} \mathrm{C}-8\right), 9.3$ (q, $\left.\mathrm{CH}_{3} \mathrm{C}-4\right), 7.8$ (q, C-1)

LRMS (EI), $m / z$ (relative intensity): 378 ([M] $\left.{ }^{+}, 4\right), 361$ (81), 360 (100), 345 (45), 343 (47), 342

HRMS $\mathrm{m} / \mathrm{z}$ calcd for $\mathrm{C}_{22} \mathrm{H}_{34} \mathrm{O}_{5}+\mathrm{H}: 379.2485$; found: $379.2490\left(\mathrm{CI}, \mathrm{NH}_{3}\right.$ ).

$(4 R, 5 R, 6 R, 10 S)$-5,9-Dihydroxy-4,6,8,10-tetramethyl-11-(phenylmethoxy)undecan-3,7-dione (150).

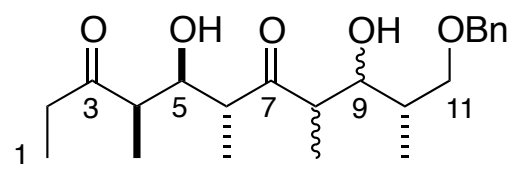

150

$\mathrm{FeCl}_{3} \cdot 6 \mathrm{H}_{2} \mathrm{O}$ (532 mg, $1.97 \mathrm{mmol}$ ) was added to a stirred solution of aldol adducts 149 (coming from the reaction with $\mathrm{Li}$ enolate $)(1.51 \mathrm{~g}, 2.81 \mathrm{mmol})$ in acetone $(63 \mathrm{~mL})$ at room temperature. After $1.5 \mathrm{~h}$, the mixture was diluted with ethyl acetate and washed sequentially with a saturated aq $\mathrm{NaHCO}_{3}, \mathrm{H}_{2} \mathrm{O}$ and brine, dried over $\mathrm{Na}_{2} \mathrm{SO}_{4}$, concentrated to afford the crude titled compound $(1.26 \mathrm{~g})$ that was used directly in the next step. The crude from a smaller scale reaction as above was fractionated by FCC (30\% ethyl acetate in hexane) to give the titled compound $(90 \%)$. $[\alpha]_{\mathrm{D}}$ $+14\left(c 1.1, \mathrm{CHCl}_{3}\right)$

IR $v_{\max }: 3479,1706 \mathrm{~cm}^{-1}$

${ }^{1} \mathbf{H}$ NMR $\left(500 \mathrm{MHz}, \mathrm{CDCl}_{3}\right)$ 8: 7.40-7.21 (5H, m, Ph), $4.53(1 \mathrm{H}, \mathrm{d}, J=12 \mathrm{~Hz}, \mathrm{HCPh}) 4.50(2 \mathrm{H}$, $\mathrm{d}, J=12 \mathrm{~Hz}, \mathrm{HCPh}), 4.11(1 \mathrm{H}, \mathrm{ddd}, J=3,3.5,8.5 \mathrm{~Hz}, \mathrm{HC}-5), 3.90(1 \mathrm{H}$, br d, $J=9 \mathrm{~Hz}, \mathrm{HC}-9)$, $3.82\left(1 \mathrm{H}\right.$, br s, HOC-9), 3.61-3.54 (2H, m, $\left.\mathrm{H}_{2} \mathrm{C}-11\right), 3.40(1 \mathrm{H}, \mathrm{d}, J=3.5 \mathrm{~Hz}, \mathrm{HOC}-5), 2.99(1 \mathrm{H}$, dq, $J=8.5,7 \mathrm{~Hz}, \mathrm{HC}-6), 2.73(1 \mathrm{H}, \mathrm{dq}, J=2.5,7 \mathrm{~Hz}, \mathrm{HC}-8), 2.64(1 \mathrm{H}, \mathrm{dq}, J=3,7 \mathrm{~Hz}, \mathrm{HC}-4)$, 
2.61-2.44 (2H, m, $\left.\mathrm{H}_{2} \mathrm{C}-2\right), 1.99-1.85$ (1H, m, HC-10), 1.14 (3H, d, J = 7 Hz, H $\left.\mathrm{H}_{3} \mathrm{CC}-4\right), 1.14$ (3H, $\left.\mathrm{d}, J=7 \mathrm{~Hz}, \mathrm{H}_{3} \mathrm{CC}-8\right), 1.04\left(3 \mathrm{H}, \mathrm{t}, J=7.5 \mathrm{~Hz}, \mathrm{H}_{3} \mathrm{C}-1\right), 1.01\left(3 \mathrm{H}, \mathrm{d}, J=7 \mathrm{~Hz}, \mathrm{H}_{3} \mathrm{CC}-6\right), 0.89(3 \mathrm{H}$, $\left.\mathrm{d}, J=7 \mathrm{~Hz}, \mathrm{H}_{3} \mathrm{CC}-10\right)$

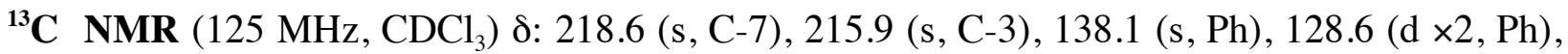
127.9 (d, Ph), 127.9 (d ×2, Ph), 75.3 (d, C-9), 74.9 (t, C-11), 73.9 (d, C-5), 73.6 (t, $\left.\mathrm{CH}_{2} \mathrm{Ph}\right), 50.1$ (d, C-8), 47.0 (d, C-4), 45.7 (d, C-6), 36.2 (d, C-10), 34.9 (t, C-2), 14.3 (q, $\left.\mathrm{CH}_{3} \mathrm{C}-6\right), 13.9$ (q, $\left.\mathrm{CH}_{3} \mathrm{C}-10\right), 9.7$ (q, $\left.\mathrm{CH}_{3} \mathrm{C}-4\right), 8.1\left(\mathrm{q}, \mathrm{CH}_{3} \mathrm{C}-8\right), 7.9$ (q, C-1)

LRMS (CI, $\left.\mathrm{NH}_{3}\right), m / z$ (relative intensity): 379 ([M+1] $\left.]^{+}, 43\right), 265$ (51), 218 (27), 201 (39), 196 (50), $183(38), 179(28), 108(27), 91(100)$

HRMS $m / z$ calcd for $\mathrm{C}_{22} \mathrm{H}_{34} \mathrm{O}_{5}+\mathrm{H}$ : 379.2485; found: $379.2487\left(\mathrm{CI}, \mathrm{NH}_{3}\right)$.

$(2 S, 3 R, 5 R, 6 R)-T e t r a h y d r o-2-h y d r o x y-3,5-d i m e t h y l-6-((R)-1-m e t h y l-2-o x o b u t y l)-2-((S)-1-$ methyl-2-(phenylmethoxy)ethyl)-4H-pyran-4-one (151).

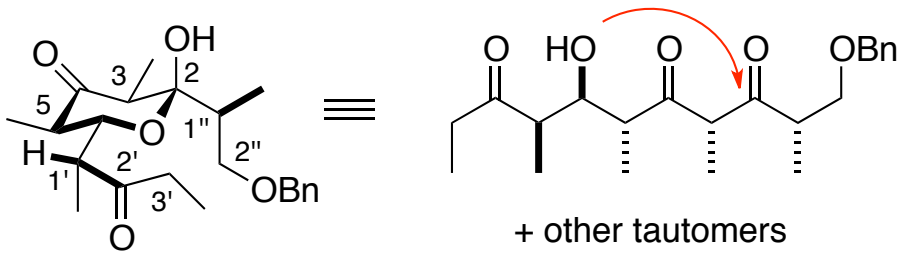

151

DMP (1.25 g, $2.95 \mathrm{mmol})$ was added to a stirred solution of the above crude diols (1.26 $\mathrm{g}$; from $1.51 \mathrm{~g}$ of aldol adducts) in $\mathrm{CH}_{2} \mathrm{Cl}_{2}(200 \mathrm{~mL})$ at room temperature. After $3 \mathrm{~h}$, the reaction was washed sequentially with a $1: 1(\mathrm{v} / \mathrm{v})$ mixture of saturated aq $\mathrm{NaHCO}_{3}$ and $10 \%$ aq $\mathrm{Na}_{2} \mathrm{SO}_{3}, \mathrm{H}_{2} \mathrm{O}$ and brine, dried over $\mathrm{Na}_{2} \mathrm{SO}_{4}$, concentrated, and fractionated by FCC (20-50\% ethyl acetate in hexane) to give recovered 150 (200 $\mathrm{mg}, 19 \%$ from 149) and the titled compound as the predominant component in a mixture of ring-chain tautomers (842 $\mathrm{mg}, 80 \%$ from 149). 
Resubjecting recovered 150 to the above reaction conditions gave additional 151 (148 $\mathrm{mg}, 14 \%$ from 149).

IR $v_{\max }: 3429,1717 \mathrm{~cm}^{-1}$

${ }^{1} \mathbf{H}$ NMR $\left(500 \mathrm{MHz}, \mathrm{CDCl}_{3}\right) \delta$ (major diastereomer only): 7.40-7.20 (5H, m, Ph), $4.15(1 \mathrm{H}, \mathrm{d}, J$ $=12 \mathrm{~Hz}, \mathrm{HCPh}), 4.41(1 \mathrm{H}, \mathrm{d}, J=12 \mathrm{~Hz}, \mathrm{HCPh}), 4.32(1 \mathrm{H}, \mathrm{dd}, J=3,10.5 \mathrm{~Hz}, \mathrm{HC}-6), 3.59(1 \mathrm{H}$, dd, $J=6.5,9.5 \mathrm{~Hz}, \mathrm{HC}-2 "), 3.49$ (1H, dd, $J=5,9.5 \mathrm{~Hz}, \mathrm{HC}-2 "), 3.33(1 \mathrm{H}, \mathrm{s}, \mathrm{HO}), 2.77(1 \mathrm{H}, \mathrm{br}$ q, $J=6.5 \mathrm{~Hz}, \mathrm{HC}-3), 2.64\left(1 \mathrm{H}, \mathrm{dq}, J=3,7 \mathrm{~Hz}, \mathrm{HC}-1^{\prime}\right), 2.58-2.35$ (3H, m, $\mathrm{H}_{2} \mathrm{C}-3$ ', HC-5), 2.18 $(1 \mathrm{H}, \mathrm{ddq}, J=5,6.5,7 \mathrm{~Hz}, \mathrm{HC}-1 "), 1.14\left(3 \mathrm{H}, \mathrm{d}, J=7 \mathrm{~Hz}, \mathrm{H}_{3} \mathrm{CC}-1^{\prime}\right), 1.09(3 \mathrm{H}, \mathrm{d}, J=6.5 \mathrm{~Hz}$, $\left.\mathrm{H}_{3} \mathrm{CC}-3\right), 1.02\left(3 \mathrm{H}, \mathrm{t}, J=7.5 \mathrm{~Hz}, \mathrm{H}_{3} \mathrm{C}-4{ }^{\prime}\right), 0.99\left(3 \mathrm{H}, \mathrm{d}, J=6.5 \mathrm{~Hz}, \mathrm{H}_{3} \mathrm{CC}-5\right), 0.98(3 \mathrm{H}, \mathrm{d}, J=7$ $\left.\mathrm{Hz}, \mathrm{H}_{3} \mathrm{CC}-1 "\right)$

${ }^{13} \mathbf{C}$ NMR (125 MHz, $\mathrm{CDCl}_{3}$ ) $\delta$ (major diastereomer only): 211.5 (s, C-2'), 209.0 (s, C-4), 138.0 (s, Ph), $128.6(\mathrm{~d} \times 2, \mathrm{Ph}), 127.9(\mathrm{~d}, \mathrm{Ph}), 127.7(\mathrm{~d} \times 2, \mathrm{Ph}), 102.2(\mathrm{~s}, \mathrm{C}-2), 74.5$ (d, C-6), $73.4(\mathrm{t}$, $\left.\mathrm{CH}_{2} \mathrm{Ph}\right), 72.8$ (t, C-2"), 51.4 (d, C-3), 47.8 (d, C-1'), 46.5 (d, C-5), 41.4 (d, C-1"), 33.4 (t, C-3'), 12.0 (q, $\mathrm{CH}_{3} \mathrm{C}-1$ "), 9.4 (q, $\mathrm{CH}_{3} \mathrm{C}-3$ or $\left.\mathrm{CH}_{3} \mathrm{C}-5\right), 9.3$ (q, $\mathrm{CH}_{3} \mathrm{C}-3$ or $\left.\mathrm{CH}_{3} \mathrm{C}-5\right), 8.07$ (q, C-4' or $\left.\mathrm{CH}_{3} \mathrm{C}-1 "\right), 8.06$ (q, C-4' or $\left.\mathrm{CH}_{3} \mathrm{C}-1 "\right)$

LRMS (CI, $\mathrm{NH}_{3}$ ), $m / z$ (relative intensity): 394 ([M+18] $\left.]^{+}, 76\right), 377\left([\mathrm{M}+1]^{+}, 21\right), 359$ (31), 212 (45), 200 (49), 183 (100), 108 (28), 91 (46)

HRMS $\mathrm{m} / \mathrm{z}$ calcd for $\mathrm{C}_{22} \mathrm{H}_{32} \mathrm{O}_{5}+\mathrm{NH}_{4}: 394.2593$; found: $394.2596\left(\mathrm{CI}, \mathrm{NH}_{3}\right)$. 
$(1 S, 3 S, 5 S, 7 S, 8 R, 9 S, 10 R)-3-E t h y l-8,9,10-t r i m e t h y l-5-[(S)$-1-methyl-2-(phenylmethoxy)ethyl]-

2,4,6-trioxatricyclo[3.3.1.1 $\left.{ }^{3,7}\right]$ decan-1-ol (ent-10-epi-116).

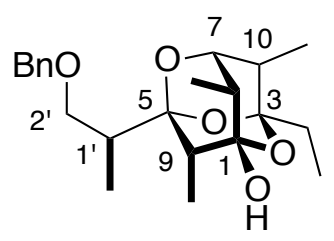

ent-10-epi-116

A solution of imidazole (539 mg, $7.92 \mathrm{mmol})$ and hemiacetals 151 (432 mg, $1.15 \mathrm{mmol})$ in $\mathrm{CHCl}_{3}$ (14.4 mL; previously neutralized by passing through basic alumina) was stirred at $40{ }^{\circ} \mathrm{C}$. After $50 \mathrm{~h}$, the mixture was diluted in ethyl acetate, washed sequentially with $1 \%$ aq citric acid $(\times 3)$, saturated aq $\mathrm{NaHCO}_{3}$ and brine, dried over $\mathrm{Na}_{2} \mathrm{SO}_{4}$, concentrated, and fractionated by FCC (20\% ethyl acetate in hexane) to crude ent-10-epi-116 (234 mg) and recovered hemiacetals 151 (113 mg, 26\%). The hemiacetal fraction was resubjected to the isomerization conditions and the crude ent-10-epi-116 was fractioned by FCC (5\% ethyl acetate in toluene) to yield the titled compound (225 mg, 51\%). $[\alpha]_{\mathrm{D}}-41\left(c 1.1, \mathrm{CHCl}_{3}\right)$

IR $v_{\text {max }}: 3424 \mathrm{~cm}^{-1}$

${ }^{1} \mathbf{H}$ NMR $\left(500 \mathrm{MHz}, \mathrm{CDCl}_{3}\right)$ 8: 7.37-7.23 (5H, m, Ph), $4.56(1 \mathrm{H}, \mathrm{d}, J=12 \mathrm{~Hz}, \mathrm{HCPh}), 4.46(1 \mathrm{H}$, d, $J=12 \mathrm{~Hz}, \mathrm{HCPh}), 3.90(1 \mathrm{H}, \mathrm{dd}, J=2.5,9 \mathrm{~Hz}, \mathrm{HC}-2 '), 3.73(1 \mathrm{H}, \mathrm{d}, J=3.5 \mathrm{~Hz}, \mathrm{HC}-7), 3.35$ (1H, dd, $J=9,9.5 \mathrm{~Hz}, \mathrm{HC}-2$ '), 2.63 (1H, s, HO), 2.10-1.97 (4H, m, HC-1', HC-8, HC-9, HC10,), 1.63(1 \mathrm{H}, \mathrm{dq}, J=14.5,7.5 \mathrm{~Hz}, \mathrm{HCC}-3), 1.55(1 \mathrm{H}, \mathrm{dq}, J=14.5,7.5 \mathrm{~Hz}, \mathrm{HCC}-3), 1.11(3 \mathrm{H}$, d, $\left.J=7 \mathrm{~Hz}, \mathrm{H}_{3} \mathrm{CC}-8\right), 1.04\left(3 \mathrm{H}, \mathrm{d}, J=7 \mathrm{~Hz}, \mathrm{H}_{3} \mathrm{CC}-1\right.$ '), $0.97\left(3 \mathrm{H}, \mathrm{d}, J=6.5 \mathrm{~Hz}, \mathrm{H}_{3} \mathrm{CC}-9\right), 0.92$ $\left(3 \mathrm{H}, \mathrm{t}, J=7.5 \mathrm{~Hz}, \mathrm{H}_{3} \mathrm{CCC}-3\right), 0.89\left(3 \mathrm{H}, \mathrm{d}, J=7 \mathrm{~Hz}, \mathrm{H}_{3} \mathrm{CC}-10\right)$

${ }^{13}$ C NMR $\left(125 \mathrm{MHz}, \mathrm{CDCl}_{3}\right)$ 8: $139.1(\mathrm{~s}, \mathrm{Ph}), 128.5(\mathrm{~d} \times 2, \mathrm{Ph}), 127.8(\mathrm{~d}, \mathrm{Ph}), 127.5(\mathrm{~d} \times 2, \mathrm{Ph})$, 103.0 (s, C-3), 102.9 (s, C-5), 97.6 (s, C-1), 78.1 (d, C-7), 73.3 (t, $\left.\mathrm{CH}_{2} \mathrm{Ph}\right), 71.3$ (d, C-2'), 38.8 (d, 
C-1'), 36.9 (d, C-10), 35.8 (d, C-8), 34.9 (d, C-9), 29.6 (t, $\left.\mathrm{CH}_{2} \mathrm{C}-3\right), 13.3$ (q, $\left.\mathrm{CH}_{3} \mathrm{C}-8\right), 12.5$ (q, $\left.\mathrm{CH}_{3} \mathrm{C}-10\right), 11.1$ (q, $\mathrm{CH}_{3} \mathrm{C}-1$ '), 6.8 (q, $\left.\mathrm{CH}_{3} \mathrm{C}-9\right), 6.5$ (q, $\left.\mathrm{CH}_{3} \mathrm{CC}-3\right)$

LRMS (CI, $\left.\mathrm{NH}_{3}\right), m / z$ (relative intensity): $394\left([\mathrm{M}+18]^{+}, 70\right), 377\left([\mathrm{M}+1]^{+}, 33\right), 376(15), 359$ (100), 227 (33), 212 (33), 183 (69), 165 (34), 101 (56), 91 (57)

HRMS $\mathrm{m} / \mathrm{z}$ calcd for $\mathrm{C}_{22} \mathrm{H}_{32} \mathrm{O}_{5}+\mathrm{NH}_{4}: 394.2594$; found: $394.2593\left(\mathrm{CI}, \mathrm{NH}_{3}\right)$.

\section{Methyl (3R,4S)-Tetrahydro-4-hydroxy-2H-thiopyran-3-carboxylate (155)}

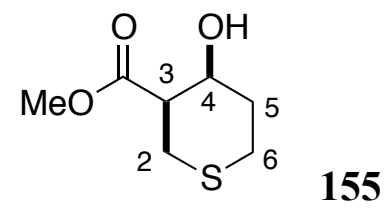

Procedure adapted from Hayakawa R.; Shimizu M. Synlett 1999, 1328-1330. A suspension of Bakers' yeast (Fleischmann's; $5.59 \mathrm{~g})$ in distilled water $(55.5 \mathrm{~mL})$ was stirred (orbital shaker at $150 \mathrm{rpm}$ ) at room temperature. After $30 \mathrm{~min}$, DMSO $(0.40 \mathrm{~mL})$ was added and stirring continued for $30 \mathrm{~min}$. A solution of 2-ketoester $154(326 \mathrm{mg}, 1.87 \mathrm{mmol})$ in absolute ethanol $(5.5 \mathrm{~mL})$ was added. After stirring for 1 day, Celite ${ }^{\circledR}(40 \mathrm{~mL})$ and ethyl acetate $(40 \mathrm{~mL})$ were added and stirring continued for $30 \mathrm{~min}$. The resulting mixture was filtered through a bed of Celite ${ }^{\circledR}$ in a sintered glass funnel rinsing with ethyl acetate and the combined filtrate and washings were extracted with ethyl acetate. The combined organic layers were dried over $\mathrm{Na}_{2} \mathrm{SO}_{4}$, concentrated, and fractionated by FCC (50\% ethyl acetate in hexanes) to yield the title compound ( $250 \mathrm{mg}, 75 \%$; 93\% ee by HPLC analysis of the benzoyl derivative). A similar experiment conducted with $7.3 \mathrm{~g}$ of $\mathbf{1 5 4}$ and $130 \mathrm{~g}$ of Baker's yeast (distributed in $15 \times 250 \mathrm{~mL}$ Erlenmeyer flasks) gave the title compound ( $4.24 \mathrm{~g}, 57 \%$; $93 \%$ ee).

$[\alpha]_{\mathrm{D}}+35(c 1.3$, benzene $)$ 
IR $v_{\max } 3504 \mathrm{~cm}^{-1}$.

${ }^{1} \mathbf{H}$ NMR $\left(500 \mathrm{MHz}, \mathrm{CDCl}_{3}\right) \delta 4.18(1 \mathrm{H}, \mathrm{ddd}, J=2.5,2.5,5 \mathrm{~Hz}, \mathrm{HC}-4), 3.72\left(3 \mathrm{H}, \mathrm{s}, \mathrm{H}_{3} \mathrm{CO}\right)$, $3.16(1 \mathrm{H}, \mathrm{dd}, J=10.5,13.5 \mathrm{~Hz}, \mathrm{HC}-2), 2.98(1 \mathrm{H}, \mathrm{ddd}, J=2.5,11,13.5 \mathrm{~Hz}, \mathrm{HC}-6), 2.85$ (1H, dt, $J=2.5,2.5,10.5 \mathrm{~Hz}, \mathrm{HC}-3), 2.57$ (1H, br d, $J=13.5 \mathrm{~Hz}, \mathrm{HC}-2), 2.32$ (1H, ddd, $J=3.5,4,13.5$ Hz, HC-6), 2.19 (1H, m, $J=2.5,4,5,14$ Hz, HC-5), 1.89 (1H, ddt, $J=2.5,3,11,14$ Hz, HC-5).

${ }^{13}$ C NMR (125 MHz, $\left.\mathrm{CDCl}_{3}\right) \delta 174.3(\mathrm{~s}, \mathrm{C}=\mathrm{O}), 65.9(\mathrm{~d}, \mathrm{C}-4), 52.2\left(\mathrm{q}, \mathrm{CH}_{3} \mathrm{O}\right), 47.6(\mathrm{~d}, \mathrm{C}-3)$, $33.5(t, C-5), 25.1(t, C-2), 22.9$ (t, C-6).

LRMS (EI), m/z (relative intensity): $176\left([\mathrm{M}]^{+}, 84\right), 158$ (38), 126 (18), 99 (100), 98 (60), 87 (66), 55 (27).

HRMS $m / z$ calcd for $\mathrm{C}_{7} \mathrm{H}_{12} \mathrm{O}_{3} \mathrm{~S}$ : 176.0507; found: 176.0510 (EI).

\section{(3S,4S)-3-(Hydroxymethyl)-tetrahydro-2H-thiopyran-4-ol (156)}

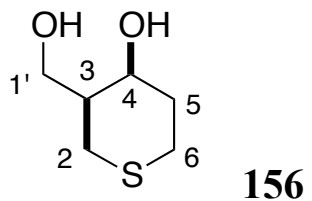

$\mathrm{NaBH}_{4}(1.77 \mathrm{~g}, 45.4 \mathrm{mmol})$ was added slowly in small portions to a stirred solution of $155(2.05 \mathrm{~g}, 11.3 \mathrm{mmol})$ in methanol $(28.3 \mathrm{~mL})$ at room temperature . After $35 \mathrm{~min}$, the mixture was neutralized to $\mathrm{pH} 7$ by addition of $10 \%$ aq $\mathrm{HCl}$. The mixture was diluted with $\mathrm{MeOH}$ and filtered though a plug of silica gel rinsing with $20 \%$ (v/v) methanol in $\mathrm{CH}_{2} \mathrm{Cl}_{2}$. The combined filtrate and washings were concentrated. The residue was taken up in $1 \mathrm{M}$ aq $\mathrm{NaOH}$ and after stirred for $1 \mathrm{~h}$, the aqueous layer was extracted with $\mathrm{CH}_{2} \mathrm{Cl}_{2}$, dried over $\mathrm{Na}_{2} \mathrm{SO}_{4}$, concentrated, and fractionated by FCC (50\% ethyl acetate in hexanes to $100 \%$ ethyl acetate) to yield the title 
compound (1.23 g, 73\%).[known compound: Hayakawa, R.; Shimizu, M. Synlett 1999, 12981300.]

$[\alpha]_{\mathrm{D}}+17\left(c 0.7, \mathrm{CHCl}_{3}\right)$

IR $v_{\max } 3372 \mathrm{~cm}^{-1}$.

${ }^{1} \mathbf{H}$ NMR $\left(500 \mathrm{MHz}, \mathrm{CDCl}_{3}\right) \delta 4.16(1 \mathrm{H}, \mathrm{ddd}, J=2.5,3,5.5 \mathrm{~Hz}, \mathrm{HC}-4), 3.84(1 \mathrm{H}, \mathrm{dd}, J=5.5,11$ Hz, HC-1'), 3.82 (1H, dd, $J=4.5,11 \mathrm{~Hz}, \mathrm{HC}-1$ '), 3.03 (1H, dd, $J=105 ., 13.5 \mathrm{~Hz}, \mathrm{HC}-2), 2.99$ (1H, ddd, $J=2.5,11,14 \mathrm{~Hz}, \mathrm{HC}-6), 2.85$ (1H, br s, HOC-4), 2.59 (1H, br s, HOC-7), 2.37-2.30 (2H, m, HC-2, HC-6), 2.08 (1H, dddd, $J=3,5.5,5.5,14 \mathrm{~Hz}, \mathrm{HC}-5$ ), 2.00 (1H, ddddd, $J=2.5,3$, 4.5, 5.5, $10.5 \mathrm{~Hz}, \mathrm{HC}-3), 1.91$ (1H, dddd, $J=3,3.5,11,14 \mathrm{~Hz}, \mathrm{HC}-5)$.

${ }^{13}$ C NMR (125 MHz, $\left.\mathrm{CDCl}_{3}\right)$ \& 69.2 (d, C-4), 66.3 (t, C-1'), 43.2 (d, C-3), 34.4 (t, C-5), 25.6 (t, C-2), $23.1(\mathrm{t}, \mathrm{C}-6)$.

LRMS (EI), $m / z$ (relative intensity): 148 ([M] $\left.]^{+}, 81\right), 130$ (24), 112 (25), 99 (100), 87 (40), 79 (31), 74 (39), 57 (43).

HRMS $m / z$ calcd for $\mathrm{C}_{6} \mathrm{H}_{12} \mathrm{O}_{2} \mathrm{~S}: 148.0558$; found: 148.0552 (EI).

$(2 R, 4 \mathrm{a} S, 8 \mathrm{a} S)$-Hexahydro-2-phenylthiopyrano[4,3-d][1,3]dioxine (157)

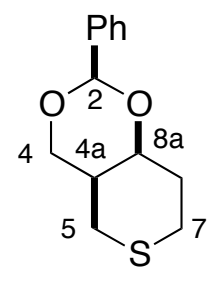

157

Benzaldehyde dimethyl acetal (2.65 mL, $18.135 \mathrm{mmol})$ and p-TsOH (58 mg, $0.30 \mathrm{mmol})$ were added to a stirred solution of diol $156(896 \mathrm{mg}, 6.04 \mathrm{mmol})$ in $\mathrm{CH}_{2} \mathrm{Cl}_{2}(60.5 \mathrm{~mL})$ at room 
temperature under Ar at rt. After 20 min, the mixture was washed with saturated aq $\mathrm{NaHCO}_{3}$, dried over $\mathrm{Na}_{2} \mathrm{SO}_{4}$, and concentrated to provide the title compound that was homogeneous by TLC and ${ }^{1} \mathrm{H}$ NMR (1.38 g, 97\%).

$[\alpha]_{\mathrm{D}}+6\left(c 0.9, \mathrm{CHCl}_{3}\right)$

IR $v_{\max } 2914 \mathrm{~cm}^{-1}$.

${ }^{1}$ H NMR $\left(500 \mathrm{MHz}, \mathrm{CDCl}_{3}\right) \delta 7.51(2 \mathrm{H}$, app d, $J=7.5 \mathrm{~Hz}, \mathrm{Ph}), 7.42-7.32(3 \mathrm{H}, \mathrm{m}, \mathrm{Ph}), 5.54$ (1H, s, HC-2), $4.21(1 \mathrm{H}, \mathrm{br} \mathrm{s}, \mathrm{HC}-8 \mathrm{a}), 4.06(1 \mathrm{H}, \mathrm{dd}, J=2.5,11.5 \mathrm{~Hz}, \mathrm{HC}-4), 3.99(1 \mathrm{H}, \mathrm{d}, J=$ $11.5 \mathrm{~Hz}, \mathrm{HC}-4), 3.57$ (1H, dd, $J=12.5,13 \mathrm{~Hz}, \mathrm{HC}-5), 3.07-3.00(1 \mathrm{H}, \mathrm{m}, J=13.5 \mathrm{~Hz}, \mathrm{HC}-7)$, $2.36(1 \mathrm{H}, \mathrm{br} \mathrm{d}, J=13 \mathrm{~Hz}, \mathrm{HC}-5), 2.33-2.24$ (2H, m, HC-7, HC-8), 2.02-1.92 (1H, m, HC-8), $1.80(1 \mathrm{H}$, br d, $J=12.5 \mathrm{~Hz}, \mathrm{HC}-4 \mathrm{a})$.

${ }^{13}$ C NMR (125 MHz, $\left.\mathrm{CDCl}_{3}\right) \delta 138.7(\mathrm{~s}, \mathrm{Ph}), 129.2(\mathrm{~d}, \mathrm{Ph}), 128.5(\mathrm{~d} \times 2, \mathrm{Ph}), 126.4(\mathrm{~d} \times 2, \mathrm{Ph})$, 102.4 (d, C-2), 74.1 (d, C-8a), 72.8 (t, C-4), 36.4 (d, C-4a), 33.6 (t, C-8), 26.3 (t, C-5), 22.5 (t, C7).

LRMS (EI), $m / z$ (relative intensity): 236 ([M] $\left.]^{+}, 100\right), 205$ (24), 130 (94), 105 (68), 99 (61), 74 $(81)$.

HRMS $m / z$ calcd for $\mathrm{C}_{13} \mathrm{H}_{16} \mathrm{O}_{2} \mathrm{~S}: 236.0871$; found: 236.0869 (EI). 


\section{((3S,4S)-4-Benzyloxy-tetrahydro-2H-thiopyran-3-yl)methanol (158)}

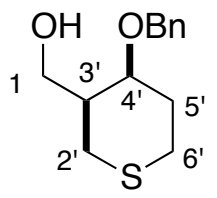

158

Procedure adapted from Takano et al, Chem Lett. 1983, 12, 1593-1596. DIBALH (1 M in toluene; $10.6 \mathrm{~mL}, 10.6 \mathrm{mmol}$ ) was added slowly via syringe (ca. $3 \mathrm{~min}$ ) to a stirred solution of benzylidene acetal $157(1.0 \mathrm{~g}, 4.2 \mathrm{mmol})$ in $\mathrm{CH}_{2} \mathrm{Cl}_{2}(42 \mathrm{~mL})$ at $0{ }^{\circ} \mathrm{C}$ under Ar. After $5 \mathrm{~min}$, the cooling bath was removed and the mixture was allowed to reach ambient temperature. After 13.5 $\mathrm{h}$, the mixture was cooled to $0{ }^{\circ} \mathrm{C}$ and a saturated solution of Rochelle's salt $(30 \mathrm{~mL})$ was added. The mixture was allowed to warm to ambient temperature and after $2 \mathrm{~h}$, was extracted with $\mathrm{CH}_{2} \mathrm{Cl}_{2}$. The combined organic layers were dried over $\mathrm{Na}_{2} \mathrm{SO}_{4}$ and concentrated to yield the title compound that was homogeneous by TLC and ${ }^{1} \mathrm{H}$ NMR (1.0 g, 99\%).

$[\alpha]_{\mathrm{D}}+62\left(c 1.2, \mathrm{CHCl}_{3}\right)$

IR $v_{\max } 3405 \mathrm{~cm}^{-1}$.

${ }^{1}$ H NMR (500 MHz, $\left.\mathrm{CDCl}_{3}\right) \delta$ 7.39-7.27 (5H, m, Ph), $4.64(1 \mathrm{H}, \mathrm{d}, J=11.5 \mathrm{~Hz}, \mathrm{HCPh}), 4.41$ $(1 \mathrm{H}, \mathrm{d}, J=11.5 \mathrm{~Hz}, \mathrm{HCPh}), 3.81(1 \mathrm{H}, \mathrm{ddd}, J=2.5,2.5,5 \mathrm{~Hz}, \mathrm{HC}-4), 3.73(1 \mathrm{H}, \mathrm{dd}, J=6.5,11$ Hz, HC-1), 3.67 (1H, dd, $J=5,11 \mathrm{~Hz}, \mathrm{HC}-1), 3.02-2.90$ (2H, m, HC-2', HC-6'), 2.41-2.29 (3H, m, HC-2', HC-5', HC-6'), 2.20 (1H, br s, HO), 2.05 (1H, dddd, $J=5,6.5$ Hz, HC-3'), 1.84-1.75 $\left(1 \mathrm{H}, \mathrm{m}, \mathrm{HC}-5^{\prime}\right)$.

${ }^{13}$ C NMR (125 MHz, $\left.\mathrm{CDCl}_{3}\right)$ \& $138.4(\mathrm{~s}, \mathrm{Ph}), 128.7(\mathrm{~d} \times 2, \mathrm{Ph}), 128.0(\mathrm{~d}, \mathrm{Ph}), 127.9(\mathrm{~d} \times 2, \mathrm{Ph})$, $75.2\left(\mathrm{~d}, \mathrm{C}-4^{\prime}\right), 70.6$ (t, $\left.\mathrm{CH}_{2} \mathrm{Ph}\right), 65.3(\mathrm{t}, \mathrm{C}-1), 43.8$ (d, C-3'), 29.8 (t, C-5'), 26.1 (t, C-2'), 23.4 (t, C-6 '). 
LRMS (EI), $m / z$ (relative intensity): 238 ([M] $\left.]^{+}, 10\right), 132$ (38), 129 (27), 99 (30), 91 (100), 65 (15).

HRMS $m / z$ calcd for $\mathrm{C}_{13} \mathrm{H}_{18} \mathrm{O}_{2} \mathrm{~S}: 238.1028$; found: 238.1023 (EI).

\section{(3R,4S)-Tetrahydro-4-benzyloxy-2H-thiopyran-3-carbaldehyde (159)}

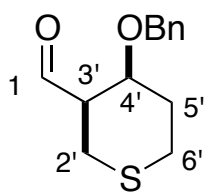

159

IBX (32 mg, $0.11 \mathrm{mmol})$ was added to a stirred solution of alcohol $158(12.5 \mathrm{mg}, 0.052$ mmol) in dry DMSO $(0.4 \mathrm{~mL})$ at room temperature under Ar. After $2 \mathrm{~h}$, the mixture was diluted in ethyl acetate, washed sequentially with saturated aq $\mathrm{NaHCO}_{3}, \mathrm{H}_{2} \mathrm{O}$ and brine, dried over $\mathrm{Na}_{2} \mathrm{SO}_{4}$, concentrated, and fractionated by FCC ( $20 \%$ ethyl acetate in hexanes) to provide the title compound as a colorless oil that was homogeneous by TLC and ${ }^{1} \mathrm{H}$ NMR $(9.5 \mathrm{mg}, 77 \%)$.

$[\alpha]_{\mathrm{D}}-14(c 1.0, \mathrm{C} 6 \mathrm{H} 6)$

IR $v_{\max } 1727 \mathrm{~cm}^{-1}$.

${ }^{1} \mathbf{H}$ NMR $\left(500 \mathrm{MHz}, \mathrm{CDCl}_{3}\right) \delta 9.55(1 \mathrm{H}, \mathrm{s}, \mathrm{HC}-1), 7.39-7.23(5 \mathrm{H}, \mathrm{m}, \mathrm{Ph}), 4.62(1 \mathrm{H}, \mathrm{d}, J=12$ $\mathrm{Hz}, \mathrm{HCPh}), 4.42(1 \mathrm{H}, \mathrm{d}, J=12 \mathrm{~Hz}, \mathrm{HCPh}), 4.23(1 \mathrm{H}, \mathrm{ddd}, J=2.5,2.5,4.5 \mathrm{~Hz}, \mathrm{HC}-4$ '), $3.13(1 \mathrm{H}$, dd, $\left.J=12,14.5 \mathrm{~Hz}, \mathrm{HC}-2^{\prime}\right), 2.98$ (1H, ddd, $\left.J=2.5,12,13.5 \mathrm{~Hz}, \mathrm{HC}-6 '\right), 2.68-2.59$ (2H, m, HC2', HC-3'), 2.43 (1H, dddd, $J=2.5,4,4.5,14.5 \mathrm{~Hz}, \mathrm{HC}-5$ '), 2.35 (1H, dddd, $J=1.5,3.5,4,13.5$ Hz, HC-6'), 1.84 (1H, dddd, $\left.J=2.5,3.5,12,14.5 \mathrm{~Hz}, \mathrm{HC}-5^{\prime}\right)$. 
${ }^{13}$ C NMR (125 MHz, $\left.\mathrm{CDCl}_{3}\right) \delta 202.4$ (s, C-1), 138.0 (s, Ph), 128.7 (d ×2, Ph), 128.1 (d, Ph), $127.8(\mathrm{~d} \times 2, \mathrm{Ph}), 71.7$ (d, C-4'), $70.6\left(\mathrm{t}, \mathrm{CH}_{2} \mathrm{Ph}\right), 54.0\left(\mathrm{~d}, \mathrm{C}-3^{\prime}\right), 29.8$ (t, C-5'), 23.0 (t, C-2'), 23.0 $(t, C-6 ')$.

LRMS (EI), $m / z$ (relative intensity): 236 ([M] $\left.]^{+}, 11\right), 157$ (17), 99 (31), 91 (100), 65 (17).

HRMS $m / z$ calcd for $\mathrm{C}_{13} \mathrm{H}_{16} \mathrm{O}_{2} \mathrm{~S}: 236.0871$; found: 236.0865 (EI).

\section{$(1 R, 2 S, 4 S, 5 R, 6 S)-6-(2-E t h y l-1,3-d i o x o l a n-2-y l)-1-[(3 S, 4 S)-t e t r a h y d r o-4-(b e n z y l o x y)-2 H-$}

\section{thiopyran-3-yl]-1-hydroxy-2,4-dimethyl-5-(triethylsilyloxy)heptan-3-one (160)}

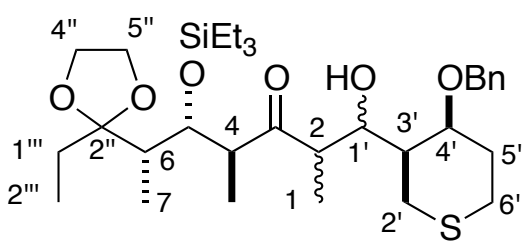

LHMDS (1 M in THF; $0.21 \mathrm{~mL}, 0.21 \mathrm{mmol})$ was added to a solution of $(+)-109(50 \mathrm{mg}$, $0.139 \mathrm{mmol})$ in THF $(0.7 \mathrm{~mL})$ at $-50{ }^{\circ} \mathrm{C}$. After $1 \mathrm{~h}$, the reaction mixture was cooled to $-78^{\circ} \mathrm{C}$ and a solution of freshly prepared aldehyde $159(40 \mathrm{mg}, 0.169 \mathrm{mmol})$ was added dropwise in THF $(0.7 \mathrm{~mL})$. After $1 \mathrm{~h}$, the reaction was quenched by addition of phosphates buffer $\mathrm{pH}=7$ ( 1 $\mathrm{mL})$, extracted with ethyl acetate, dried over $\mathrm{Na}_{2} \mathrm{SO}_{4}$, concentrated and fractionated by $\mathrm{FCC}(2 \%$ ethyl acetate in $\mathrm{CH}_{2} \mathrm{Cl}_{2}$ ) to provide a mixture of at least 3 diastereomers by TLC (62 $\mathrm{mg}, 77 \%$ ). The mixture was used in the next reaction.

IR $v_{\max } 3489 \mathrm{~cm}^{-1}$.

${ }^{1}$ H NMR (500 MHz, $\left.\mathrm{CDCl}_{3}\right)$ - complex

${ }^{13}$ C NMR (125 MHz, $\left.\mathrm{CDCl}_{3}\right)$ - complex 
HRMS $m / z$ calcd for $\mathrm{C}_{32} \mathrm{H}_{54} \mathrm{O}_{6} \mathrm{Si}_{\mathrm{S}}+\mathrm{Na}$ : 617.3302; found: 617.3294 (ESI).

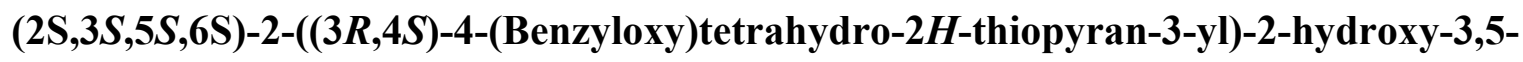
dimethyl-6-((S)-1-methyl-2-oxobutyl)tetrahydro-4H-pyran-4-one (161)

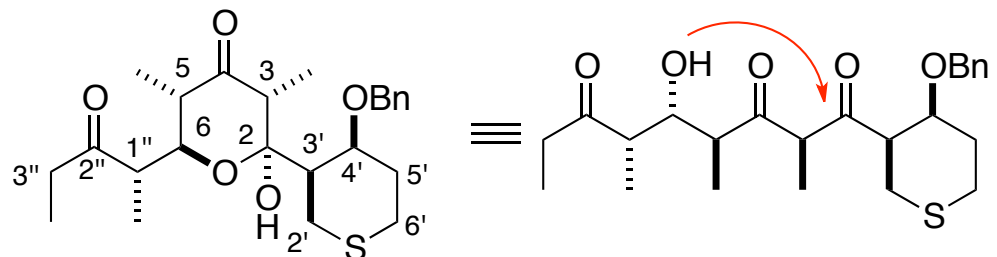

161

$\mathrm{FeCl}_{3} 6 \mathrm{H}_{2} \mathrm{O}(6.5 \mathrm{mg}, 0.024 \mathrm{mmol})$ was added to a stirred solution of aldol adducts $\mathbf{1 6 0}$ (20 $\mathrm{mg}, 0.034 \mathrm{mmol})$ in acetone $(0.8 \mathrm{~mL})$ at room temperature. After $1 \mathrm{~h}$, the mixture was diluted with ethyl acetate and washed sequentially with saturated aq $\mathrm{NaHCO}_{3}, \mathrm{H}_{2} \mathrm{O}$ and brine, dried over $\mathrm{Na}_{2} \mathrm{SO}_{4}$, and concentrated. The residue $(14 \mathrm{mg})$ was taken up in $\mathrm{CH}_{2} \mathrm{Cl}_{2}(2.4 \mathrm{~mL})$ and DMP (15 mg, $0.035 \mathrm{mmol}$ ) was added to the stirred solution. After $3 \mathrm{~h}$, the mixture was washed sequentially with a 1:1 mixture $(\mathrm{v} / \mathrm{v})$ of saturated aq $\mathrm{NaHCO}_{3}$ and saturated aq $\mathrm{Na}_{2} \mathrm{SO}_{3}, \mathrm{H}_{2} \mathrm{O}$ and brine, dried over $\mathrm{Na}_{2} \mathrm{SO}_{4}$, and concentrated. The residue (16 mg) was taken up in $\mathrm{CDCl}_{3}(0.6$ $\mathrm{mL}$; previously passed through basic alumina), imidazole $(22 \mathrm{mg}, 0.32 \mathrm{mmol})$ was added, and the mixture was heated to $40{ }^{\circ} \mathrm{C}$ (oil bath temperature). After $19.5 \mathrm{~h}$ (reaction monitored by ${ }^{1} \mathrm{H}$ NMR), the mixture was diluted with ethyl acetate, washed sequentially with $1 \%$ aq citric acid, $\mathrm{NaHCO}_{3}$, and brine, dried over $\mathrm{Na}_{2} \mathrm{SO}_{4}$, concentrated, and fractionated by PTLC ( $20 \%$ ethyl acetate in hexanes; multiple development) to give the title compound (5.1 $\mathrm{mg}, 31 \%)$.

$[\alpha]_{\mathrm{D}}+90\left(c 0.35, \mathrm{CHCl}_{3}\right)$

IR $v_{\max } 3384 \mathrm{~cm}^{-1}$. 
${ }^{1} \mathbf{H}$ NMR $\left(500 \mathrm{MHz}, \mathrm{CDCl}_{3}\right) \delta$ 7.39-7.22 (5H, m, Ph), $5.51(1 \mathrm{H}, \mathrm{s}, \mathrm{HO}), 4.57(1 \mathrm{H}, \mathrm{d}, J=11 \mathrm{~Hz}$ HCPh), $4.38(1 \mathrm{H}, \mathrm{dd}, J=2.5,10.5 \mathrm{~Hz}, \mathrm{HC}-6), 4.35(1 \mathrm{H}, \mathrm{br}$ s, HC-4'), $4.25(1 \mathrm{H}, \mathrm{d}, J=11 \mathrm{~Hz}$, HCPh), 3.09 (1H, dd, $J=13.5,13.5 \mathrm{~Hz}, \mathrm{HC}-2$ '), 2.96 (1H, dt, $J=2,13,13.5 \mathrm{~Hz}, \mathrm{HC}-6$ '), 2.76 $(1 \mathrm{H}, \mathrm{dq}, J=2.5,7 \mathrm{~Hz}, \mathrm{HC}-1 "), 2.65(1 \mathrm{H}, \mathrm{dq}, J=10.5,6.5 \mathrm{~Hz}, \mathrm{HC}-5), 2.58(1 \mathrm{H}, \mathrm{q}, J=7 \mathrm{~Hz}, \mathrm{HC}-$ 3), 2.54-2.47 (3H, m, $\left.\mathrm{H}_{2} \mathrm{C}-3 ", \mathrm{HC}-5^{\prime}\right), 2.26(1 \mathrm{H}, \mathrm{br} \mathrm{d}, J=13.5 \mathrm{~Hz}, \mathrm{HC}-6$ '), 2.17-2.09 (2H, m, HC-2', HC-3'), 1.72 (1H, dddd, $\left.J=1.5,3.5,13,13.5 \mathrm{~Hz}, \mathrm{HC}-5^{\prime}\right), 1.24$ (3H, d, $J=7 \mathrm{~Hz}, \mathrm{H}_{3} \mathrm{CC}-$ 1"), $1.12\left(3 \mathrm{H}, \mathrm{d}, J=7 \mathrm{~Hz}, \mathrm{H}_{3} \mathrm{CC}-3\right), 1.04\left(3 \mathrm{H}, \mathrm{t}, J=7.5 \mathrm{~Hz}, \mathrm{H}_{3} \mathrm{CC}-4 "\right), 1.02(3 \mathrm{H}, \mathrm{d}, J=6.5 \mathrm{~Hz}$, $\left.\mathrm{H}_{3} \mathrm{CC}-5\right)$.

${ }^{13}$ C NMR (125 MHz, $\left.\mathrm{CDCl}_{3}\right)$ \& 211.3 (s, C-3"), 210.7 (s, C-4), 137.4 (s, Ph), 128.9 (d ×2, Ph), $128.3(\mathrm{~d}, \mathrm{Ph}), 127.4(\mathrm{~d} \times 2, \mathrm{Ph}), 102.3(\mathrm{~s}, \mathrm{C}-2), 74.2(\mathrm{~d}, \mathrm{C}-6), 73.8\left(\mathrm{~d}, \mathrm{C}-4\right.$ '), 70.1 (t, $\left.\mathrm{CH}_{2} \mathrm{Ph}\right), 51.5$ (d, C-3), 47.6 (d, C-1"), 45.3 (d, C-3'), 41.8 (d, C-5), 34.0 (t, C-3"), 29.9 (t, C-5'), 22.3 (t, C-2'), 21.9 (t, C-6'), 14.0 (q, $\mathrm{CH}_{3} \mathrm{C}-3$ ), 9.3 (q, $\left.\mathrm{CH}_{3} \mathrm{C}-5\right), 8.3$ (q, C-4"), 8.1 (q, $\mathrm{CH}_{3} \mathrm{C}-1$ ").

LRMS (EI), $m / z$ (relative intensity): 434 ([M] $\left.]^{+}, 1\right), 245$ (18), 100 (19), 91 (100), 69 (11), 57 (25).

HRMS $m / z$ calcd for $\mathrm{C}_{24} \mathrm{H}_{34} \mathrm{O}_{5} \mathrm{~S}: 434.2127$; found: 434.2117 (EI).

$(1 R, 3 R, 5 S, 7 R, 8 R, 9 R, 10 R)-3-E t h y l-8,9,10-t r i m e t h y l-5-[(S)-1-m e t h y l-2-$

(phenylmethoxy)ethyl]-1-trimethylsilyloxy-2,4,6-trioxatricyclo[3.3.1.1 $\left.{ }^{3,7}\right]$ decane (ent-10-epi163).

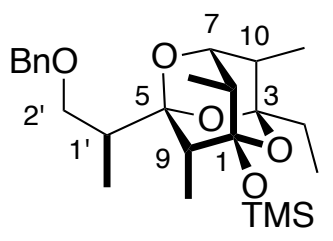

ent-10-epi-163

2,6-Lutidine (0.34 mL, $0.31 \mathrm{mg}, 2.9 \mathrm{mmol})$ and TMSOTf $(0.21 \mathrm{~mL}, 0.26 \mathrm{~g}, 1.2 \mathrm{mmol})$ were sequentially added to a stirred solution of trioxaadamantane ent-10-epi-116 (220 mg, 0.584 
$\mathrm{mmol})$ in $\mathrm{CH}_{2} \mathrm{Cl}_{2}(7.3 \mathrm{~mL})$ at $0{ }^{\circ} \mathrm{C}$ under argon. After $10 \mathrm{~min}$, additional TMSOTf $(0.21 \mathrm{~mL}$, $0.26 \mathrm{~g}, 1.2 \mathrm{mmol}$ ) was added. After a further $10 \mathrm{~min}$, the reaction was quenched by addition of $1 \%$ aq citric acid $(1 \mathrm{~mL})$ and the mixture was diluted with ethyl acetate, washed sequentially with $1 \%$ citric acid, saturated aq $\mathrm{NaHCO}_{3}$ and brine, dried over $\mathrm{Na}_{2} \mathrm{SO}_{4}$, concentrated, and fractionated by FCC ( $20 \%$ ethyl acetate in hexane) to provide the titled compound ( $229 \mathrm{mg}$, $87 \%) \cdot[\alpha]_{\mathrm{D}}-27\left(c 1.0, \mathrm{CHCl}_{3}\right)$

IR $v_{\max }: 2973,2941,2883,1454,1249,1045,906,877,842 \mathrm{~cm}^{-1}$

${ }^{1} \mathbf{H}$ NMR (500 MHz, $\left.\mathrm{CDCl}_{3}\right) \delta: 4.56(1 \mathrm{H}, \mathrm{d}, J=12 \mathrm{~Hz}, \mathrm{CHPh}), 4.45(1 \mathrm{H}, \mathrm{d}, J=12 \mathrm{~Hz}, \mathrm{CHPh})$, $3.90\left(1 \mathrm{H}, \mathrm{dd}, J=2.5,9 \mathrm{~Hz}, \mathrm{HC}-2^{\prime}\right), 3.70(1 \mathrm{H}, \mathrm{d}, J=3.5 \mathrm{~Hz}, \mathrm{HC}-5), 3.33(1 \mathrm{H}, \mathrm{dd}, J=9,9.5 \mathrm{~Hz}$, HC-2'), 2.07-1.92 (4H, m, HC-1', HC-8, HC-9, HC-10), 1.62 (1H, dq, J = 14.5, 7.5 Hz, HCC-3), $1.52(1 \mathrm{H}, \mathrm{dq}, J=14.5,7.5 \mathrm{~Hz}, \mathrm{HCC}-3), 1.06\left(3 \mathrm{H}, \mathrm{d}, J=7 \mathrm{~Hz}, \mathrm{H}_{3} \mathrm{CC}-8\right), 1.02(3 \mathrm{H}, \mathrm{d}, J=7 \mathrm{~Hz}$, $\left.\mathrm{H}_{3} \mathrm{CC}-5\right), 0.93\left(3 \mathrm{H}, \mathrm{t}, J=7.5 \mathrm{~Hz}, \mathrm{H}_{3} \mathrm{CC}-1^{\prime}\right), 0.90\left(3 \mathrm{H}, \mathrm{d}, J=7 \mathrm{~Hz}, \mathrm{H}_{3} \mathrm{CC}-9\right), 0.88(3 \mathrm{H}, \mathrm{d}, J=7$ $\left.\mathrm{Hz}, \mathrm{H}_{3} \mathrm{CC}-10\right), 0.16\left(9 \mathrm{H}, \mathrm{s}, \mathrm{H}_{3} \mathrm{CSi} \times 3\right)$

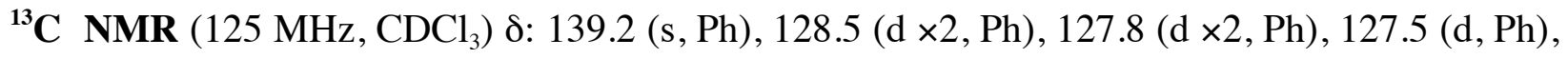
103.5 (s, C-5), 102.8 (s, C-3), 99.8 (s, C-1), 78.3 (d, C-7), 73.3 (t, $\left.\mathrm{CH}_{2} \mathrm{Ph}\right), 71.4$ (t, C-2'), 39.1 (d, C-1'), 37.4 (d, C-10), 36.9 (d, C-8), 35.5 (d, C-9), 29.6 (t, $\left.\mathrm{CH}_{2} \mathrm{C}-3\right), 13.3$ (q, $\left.\mathrm{CH}_{3} \mathrm{C}-8\right), 12.6$ (q, $\left.\mathrm{CH}_{3} \mathrm{C}-10\right), 11.1$ (q, $\left.\mathrm{CH}_{3} \mathrm{C}-1^{\prime}\right), 7.7$ (q, $\left.\mathrm{CH}_{3} \mathrm{C}-9\right), 6.5$ (q, $\left.\mathrm{CH}_{3} \mathrm{CC}-3\right), 2.2\left(\mathrm{q} \times 3, \mathrm{CH}_{3} \mathrm{Si}\right)$

LRMS (EI), $m / z$ (relative intensity): $448\left([\mathrm{M}]^{+}, 15\right), 379$ (100), 364 (5), 363 (14), 324 (17), 323 (61)

HRMS $m / z$ calcd for $\mathrm{C}_{25} \mathrm{H}_{40} \mathrm{O}_{5} \mathrm{Si}$ : 448.2645; found: 448.2644 (EI). 
(S)-2-[(1R,3R,5S,7R,8R,9R,10R)-3-Ethyl-8,9,10-trimethyl-1-trimethylsilyloxy-2,4,6-

trioxatricyclo[3.3.1.1 $\left.\left.{ }^{3,7}\right] \mathrm{dec}-5-\mathrm{yl}\right]$ propanol (ent-10-epi-164).

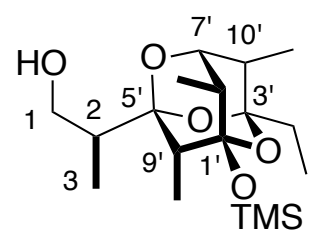

ent-10-epi-164

$10 \% \mathrm{Pd} / \mathrm{C}(163 \mathrm{mg}, 0.153 \mathrm{mmol})$ was added to a solution of trioxaadamantane ent-10-epi-163 (228 $\mathrm{mg}, 0.510 \mathrm{mmol})$ in ethanol $(64 \mathrm{~mL})$ at room temperature. After purging the flask with $\mathrm{H}_{2}$, the mixture was stirred under an atmosphere of $\mathrm{H}_{2}$ (balloon). After 15 min, the mixture was filtered through wet Celite ${ }^{\circledR}$ and the combined filtrate and EtOH washings were concentrated, and fractionated by FCC (20\% ethyl acetate in hexane) to yield the titled compound (158 $\mathrm{mg}$, $86 \%) .[\alpha]_{D}-9\left(c 1.2, \mathrm{CHCl}_{3}\right)$

IR $v_{\max }: 3469,2972,2942,2884,1465,1249,1193,903,877,843 \mathrm{~cm}^{-1}$

${ }^{1} \mathbf{H}$ NMR (500 MHz, $\left.\mathrm{CDCl}_{3}\right) \delta: 3.82(1 \mathrm{H}, \mathrm{dd}, J=3.5,1 \mathrm{~Hz}, \mathrm{HC}-7$ '), $3.75(2 \mathrm{H}$, ap dd, $J=5,6 \mathrm{~Hz}$, $\left.\mathrm{H}_{2} \mathrm{C}-1\right), 3.07(1 \mathrm{H}, \mathrm{t}, J=6 \mathrm{~Hz}, \mathrm{HO}), 2.11(1 \mathrm{H}, \mathrm{dq}, J=3.5,7 \mathrm{~Hz}, \mathrm{HC}-10 '), 2.03-1.96(2 \mathrm{H}, \mathrm{m}, \mathrm{HC}-$ 8', HC-9'), $1.92(1 \mathrm{H}$, ddq, $J=5,5,7 \mathrm{~Hz}, \mathrm{HC}-2), 1.66(1 \mathrm{H}, \mathrm{dq}, J=14,7.5 \mathrm{~Hz}, \mathrm{HCC}-3$ ') $1.54(1 \mathrm{H}$, dq, $\left.J=14,7.5 \mathrm{~Hz}, \mathrm{HCC}-3^{\prime}\right), 1.07\left(3 \mathrm{H}, \mathrm{d}, J=7 \mathrm{~Hz}, \mathrm{H}_{3} \mathrm{CC}-8^{\prime}\right), 0.94\left(3 \mathrm{H}, \mathrm{t}, J=7.5 \mathrm{~Hz}, \mathrm{H}_{3} \mathrm{CCC}-3^{\prime}\right)$, $0.92\left(3 \mathrm{H}, \mathrm{d}, J=7 \mathrm{~Hz}, \mathrm{H}_{3} \mathrm{C}-3\right.$ or $\left.\mathrm{H}_{3} \mathrm{CC}-10\right), 0.91\left(3 \mathrm{H}, \mathrm{d}, J=7 \mathrm{~Hz}, \mathrm{H}_{3} \mathrm{C}-3\right.$ or $\left.\mathrm{H}_{3} \mathrm{CC}-10\right), 0.91(3 \mathrm{H}$, $\left.\mathrm{d}, J=6.5 \mathrm{~Hz}, \mathrm{H}_{3} \mathrm{CC}-9^{\prime}\right), 0.17\left(9 \mathrm{H}, \mathrm{s}, \mathrm{H}_{3} \mathrm{CSi} \times 3\right)$

${ }^{13}$ C NMR (125 MHz, CDCl $)$ ): 105.5 (s, C-5'), 103.1 (s, C-3'), 99.6 (s, C-1'), 78.4 (d, C-7'), 64.3 (t, C-1), 39.2 (d, C-2), 37.7 (d, C-2), 36.8 (d, C-8'), 35.5 (d, C-9'), $29.6\left(\mathrm{t}, \mathrm{CH}_{2} \mathrm{C}-3^{\prime}\right), 13.3$ (q, $\left.\mathrm{CH}_{3} \mathrm{C}-8^{\prime}\right), 12.6$ (q, $\left.\mathrm{CH}_{3} \mathrm{C}-10^{\prime}\right), 10.1$ (q, C-3), 7.6 (q, $\left.\mathrm{CH}_{3} \mathrm{C}-9^{\prime}\right), 6.5$ (q, $\left.\mathrm{CH}_{3} \mathrm{CC}-3^{\prime}\right), 2.2(\mathrm{q} \times 3$, $\left.\mathrm{CH}_{3} \mathrm{Si}\right)$ 
LRMS (EI), $m / z$ (relative intensity): 358 ([M] $\left.]^{+}, 6\right), 239$ (19), 215 (94), 197 (30), 187 (25), 143 (34), $125(28), 73(45), 69(23), 57(100)$

HRMS $m / z$ calcd for $\mathrm{C}_{18} \mathrm{H}_{34} \mathrm{O}_{5} \mathrm{Si}$ : 358.2176; found: 358.2180 (EI).

(S)-2-[(1R,3R,5S,7R,8R,9R,10R)-3-Ethyl-8,9,10-trimethyl-1-trimethylsilyloxy-2,4,6trioxatricyclo[3.3.1.1 $\left.\left.{ }^{3,7}\right] \mathrm{dec}-5-\mathrm{yl}\right]$ propanal (ent-10-epi-167).

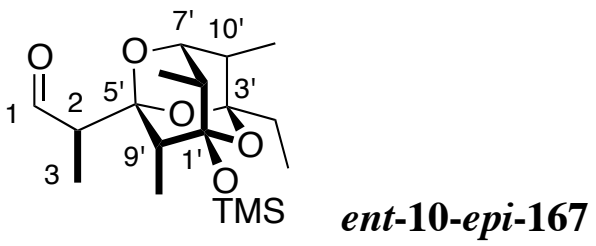

IBX (256 mg, $0.912 \mathrm{mmol})$ was added to a stirred solution of adamantane ent-10-epi-164 (294 $\mathrm{mg}, 0.820 \mathrm{mmol})$ in dry DMSO $(13 \mathrm{~mL})$ at room temperature under argon. After $12 \mathrm{~h}$, the reaction mixture was diluted with ethyl acetate, washed sequentially with saturated aq $\mathrm{NaHCO}_{3}$, water and brine, dried over $\mathrm{Na}_{2} \mathrm{SO}_{4}$, and concentrated to yield the titled compound (292 mg, $99 \%) \cdot[\alpha]_{\mathrm{D}}-70\left(c 0.8, \mathrm{CHCl}_{3}\right)$

IR $v_{\text {max }}: 1733 \mathrm{~cm}^{-1}$

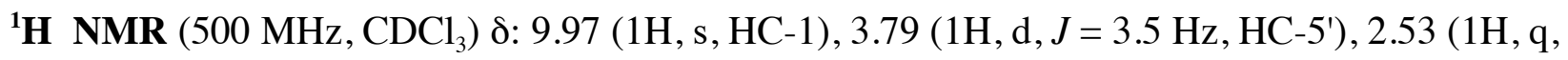
$J=7 \mathrm{~Hz}, \mathrm{HC}-2), 2.08(1 \mathrm{H}, \mathrm{dddd}, J=3.5,7 \mathrm{~Hz}, \mathrm{HC}-10 '), 2.00\left(1 \mathrm{H}\right.$, br q, $\left.J=7 \mathrm{~Hz}, \mathrm{HC}-8^{\prime}\right), 1.96$ $\left(1 \mathrm{H}, \mathrm{q}, J=6.5 \mathrm{~Hz}, \mathrm{HC}-9^{\prime}\right), 1.68\left(1 \mathrm{H}, \mathrm{dq}, J=14,7.5 \mathrm{~Hz}, \mathrm{HCC}-3^{\prime}\right), 1.57(1 \mathrm{H}, \mathrm{dq}, J=14,7.5 \mathrm{~Hz}$, HCC-3'), $1.07\left(3 \mathrm{H}, \mathrm{d}, J=7 \mathrm{~Hz}, \mathrm{H}_{3} \mathrm{CC}-8\right.$ ') $1.04\left(3 \mathrm{H}, \mathrm{d}, J=7 \mathrm{~Hz}, \mathrm{H}_{3} \mathrm{C}-3\right), 0.96(3 \mathrm{H}, \mathrm{t}, J=7.5 \mathrm{~Hz}$, $\left.\mathrm{H}_{3} \mathrm{CCC}-3^{\prime}\right), 0.95\left(3 \mathrm{H}, \mathrm{d}, J=6.5 \mathrm{~Hz}, \mathrm{H}_{3} \mathrm{CC}-9{ }^{\prime}\right), 0.92\left(3 \mathrm{H}, \mathrm{d}, J=7 \mathrm{~Hz}, \mathrm{H}_{3} \mathrm{CC}-10^{\prime}\right), 0.18(9 \mathrm{H}, \mathrm{s}$, $\left.\mathrm{H}_{3} \mathrm{CSi} \times 3\right)$

${ }^{13}$ C NMR (125 MHz, $\mathrm{CDCl}_{3}$ ) d: 204.3 (s, C-1), 103.8 (s, C-5'), 103.4 (s, C-3'), 99.7 (s, C-1'), $78.6\left(\mathrm{~d}, \mathrm{C}^{-7} \mathrm{7}^{\prime}\right), 50.6$ (d, C-2), 37.6 (d, C-10'), 36.9 (d, C-8'), 35.5 (d, C-9'), 29.6 (t, $\left.\mathrm{CH}_{2} \mathrm{C}-3^{\prime}\right), 13.2$ 
(q, $\left.\left.\mathrm{CH}_{3} \mathrm{C}-8^{\prime}\right), 12.6\left(\mathrm{q}, \mathrm{CH}_{3} \mathrm{C}-10^{\prime}\right), 7.9\left(\mathrm{q}, \mathrm{CH}_{3} \mathrm{C}-9^{\prime}\right), 6.8(\mathrm{q}, \mathrm{C}-3), 6.4\left(\mathrm{q}, \mathrm{CH}_{3} \mathrm{CC}-3\right)^{\prime}\right), 2.2(\mathrm{q} \times 3$, $\left.\mathrm{CH}_{3} \mathrm{Si}\right)$

LRMS (EI), $m / z$ (relative intensity): 356 ([M] $\left.{ }^{+}, 3\right), 231$ (40), 187 (20), 173 (13), 149 (13), 141 (16), $75(14), 73(31), 69(17), 57(100)$

HRMS $m / z$ calcd for $\mathrm{C}_{18} \mathrm{H}_{32} \mathrm{O}_{5}$ Si: 356.2019; found: 356.2020 (EI).

$\left(2 S, 3 R^{*}\right)-2-[(1 R, 3 R, 5 S, 7 R, 8 R, 9 R, 10 R)-3-E t h y l-8,9,10$-trimethyl-1-trimethylsilyloxy-2,4,6trioxatricyclo[3.3.1.1 $\left.{ }^{3,7}\right]$ dec-5-yl]pentan-3-ol (ent-10-epi-169).

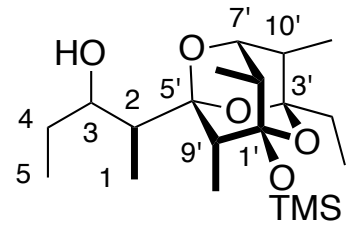

ent-10-epi-169

EtMgBr (3 M in diethyl ether; $0.071 \mathrm{~mL}, 0.21 \mathrm{mmol}$ ) was added to a stirred solution of aldehyde ent-10-epi-167 (63 mg, $0.18 \mathrm{mmol})$ in THF $(3.3 \mathrm{~mL})$ at $-78{ }^{\circ} \mathrm{C}$ under argon. After $10 \mathrm{~min}$, the reaction was quenched by addition of phosphates buffer $(\mathrm{pH}=7 ; 1 \mathrm{~mL})$, diluted with ethyl acetate and washed with phosphate buffer $(\mathrm{pH}=7)$. The aqueous layer was extracted with ethyl acetate and the combined organic layers were dried over $\mathrm{Na}_{2} \mathrm{SO}_{4}$, and concentrated to yield the titled compound as a single diastereomer $(62 \mathrm{mg}, 88 \%) .[\alpha]_{\mathrm{D}}-13\left(c 0.8, \mathrm{CHCl}_{3}\right)$

IR $v_{\text {max }}: 3554 \mathrm{~cm}^{-1}$

${ }^{1} \mathbf{H}$ NMR $\left(500 \mathrm{MHz}, \mathrm{CDCl}_{3}\right) \delta: 4.19(1 \mathrm{H}$, ap dd, $J=6,8 \mathrm{~Hz}, \mathrm{HC}-3), 3.82(1 \mathrm{H}, \mathrm{d}, J=3.5 \mathrm{~Hz}$, HC-7'), $3.43(1 \mathrm{H}, \mathrm{s}, \mathrm{HO}), 2.14(1 \mathrm{H}, \mathrm{dq}, J=3.5,7 \mathrm{~Hz}, \mathrm{HC}-10 '), 2.03(1 \mathrm{H}, \mathrm{q}, J=6.5 \mathrm{~Hz}, \mathrm{HC}-9$ '), $1.99\left(1 \mathrm{H}\right.$, br q, $\left.J=7 \mathrm{~Hz}, \mathrm{HC}-8^{\prime}\right), 1.69-1.52\left(4 \mathrm{H}, \mathrm{m}, \mathrm{HC}-2, \mathrm{H}_{2} \mathrm{CC}-3{ }^{\prime}, \mathrm{H}_{2} \mathrm{C}-4\right), 1.30$ (1H, ddq, $J=8$, 14.5, 7.5 Hz, HC-4), 1.07 (3H, d, $J=7 \mathrm{~Hz}, \mathrm{H}_{3} \mathrm{CC}-8$ '), $0.94\left(12 \mathrm{H}, \mathrm{t}, J=7.5 \mathrm{~Hz}, \mathrm{H}_{3} \mathrm{CCC}-3^{\prime}\right), 0.93$ 
$\left(3 \mathrm{H}, \mathrm{t}, J=7.5 \mathrm{~Hz}, \mathrm{H}_{3} \mathrm{C}-5\right), 0.90\left(3 \mathrm{H}, \mathrm{d}, J=7 \mathrm{~Hz}, \mathrm{H}_{3} \mathrm{CC}-10 '\right), 0.89\left(3 \mathrm{H}, \mathrm{d}, J=7 \mathrm{~Hz}, \mathrm{H}_{3} \mathrm{C}-1\right), 0.87$

$\left(3 \mathrm{H}, \mathrm{d}, J=6.5 \mathrm{~Hz}, \mathrm{H}_{3} \mathrm{CC}-8\right), 0.17\left(9 \mathrm{H}, \mathrm{s}, \mathrm{H}_{3} \mathrm{CSi} \times 3\right)$

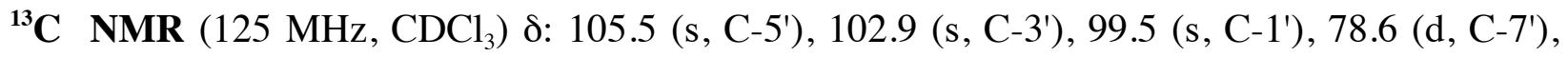
70.9 (d, C-3), 40.9 (d, C-2), 37.4 (d, C-10'), 36.9 (d, C-8'), 35.5 (d, C-9'), $29.6\left(\mathrm{t}, \mathrm{CH}_{2} \mathrm{C}-3\right.$ '), 27.6 (t, C-4), 13.2 (q, $\left.\mathrm{CH}_{3} \mathrm{C}-8^{\prime}\right), 12.6$ (q, $\mathrm{CH}_{3} \mathrm{C}-10$ '), 11.0 (q, C-5), 7.7 (q, $\left.\mathrm{CH}_{3} \mathrm{C}-9^{\prime}\right), 6.5$ (q, $\mathrm{CH}_{3} \mathrm{CC}-$ 3'), $5.3(\mathrm{q}, \mathrm{C}-1), 2.2\left(\mathrm{q} \times 3, \mathrm{CH}_{3} \mathrm{Si}\right)$

LRMS (EI), m/z (relative intensity): 386 ([M] $\left.]^{+}, 0.4\right), 243$ (99), 197 (46), 187 (42), 153 (40), 129 (36), 97 (71), 73 (77), 57 (100)

HRMS $m / z$ calcd for $\mathrm{C}_{20} \mathrm{H}_{38} \mathrm{O}_{5} \mathrm{Si}: 386.2489$; found: 386.2490 (EI).

\section{(S)-2-[(1R,3R,5S,7R,8R,9R,10R)-3-Ethyl-8,9,10-trimethyl-1-trimethylsilyloxy-2,4,6-}

trioxatricyclo[3.3.1.1 $\left.\left.{ }^{3,7}\right] \mathrm{dec}-5-\mathrm{yl}\right]$ pentan-3-one (ent-10-epi-95).

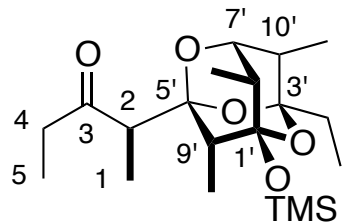

ent-10-epi-95

IBX (90 mg, $0.32 \mathrm{mmol})$ was added to a solution of adamantane ent-10-epi-169 (62 $\mathrm{mg}, 0.16$ $\mathrm{mmol})$ in dry DMSO $(2.6 \mathrm{~mL})$ at room temperature under argon. After $12.5 \mathrm{~h}$, the reaction mixture was diluted with ethyl acetate, washed sequentially with saturated aq $\mathrm{NaHCO}_{3}$, distilled water and brine, dried over $\mathrm{Na}_{2} \mathrm{SO}_{4}$, concentrated, and fractionated by FCC (10\% ethyl acetate in hexane) to yield the titled compound (61 mg, 99\%). $[\alpha]_{\mathrm{D}}-67\left(c 1.1, \mathrm{CHCl}_{3}\right)$

IR $v_{\max }: 1718 \mathrm{~cm}^{-1}$

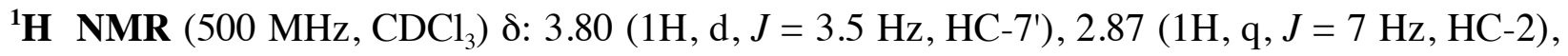
$2.76(1 \mathrm{H}, \mathrm{dq}, J=18,7.5 \mathrm{~Hz}, \mathrm{HC}-4), 2.46(1 \mathrm{H}, \mathrm{dq}, J=18,7.5 \mathrm{~Hz}, \mathrm{HC}-4), 2.02-1.92$ (3H, m, HC- 
8', HC-9',HC-10'), 1.65 (1H, dq, $\left.J=14,7.5 \mathrm{~Hz}, \mathrm{HCC}-3^{\prime}\right), 1.52\left(1 \mathrm{H}, \mathrm{dq}, J=14,7.5 \mathrm{~Hz}, \mathrm{HCC}-3^{\prime}\right)$, $1.05\left(3 \mathrm{H}, \mathrm{d}, J=7 \mathrm{~Hz}, \mathrm{H}_{3} \mathrm{CC}-8\right.$ '), $1.03\left(3 \mathrm{H}, \mathrm{d}, J=7 \mathrm{~Hz}, \mathrm{H}_{3} \mathrm{C}-1\right), 1.01\left(3 \mathrm{H}, \mathrm{t}, J=7.5 \mathrm{~Hz}, \mathrm{H}_{3} \mathrm{C}-5\right)$, $0.95\left(3 \mathrm{H}, \mathrm{d}, J=6.5 \mathrm{~Hz}, \mathrm{H}_{3} \mathrm{CC}-9^{\prime}\right), 0.94\left(3 \mathrm{H}, \mathrm{t}, J=7.5 \mathrm{~Hz}, \mathrm{H}_{3} \mathrm{CCC}-3^{\prime}\right), 0.87(3 \mathrm{H}, \mathrm{d}, J=7 \mathrm{~Hz}$, $\left.\mathrm{H}_{3} \mathrm{CC}-10^{\prime}\right), 0.16\left(9 \mathrm{H}, \mathrm{s}, \mathrm{H}_{3} \mathrm{CSi} \times 3\right)$

${ }^{13} \mathrm{C}$ NMR (125 MHz, $\mathrm{CDCl}_{3}$ ) 8: 211.8 (s, C-3), 103.2 (s, C-3'), 103.1 (s, C-5'), 99.8 (s, C-1'), 78.2 (d, C-7'), 50.6 (d, C-2), 37.4 (t, C-4), 37.2 (d, C-10'), 36.8 (d, C-8'), 35.6 (d, C-9'), 29.6 (t, $\left.\mathrm{CH}_{2} \mathrm{C}-3^{\prime}\right), 13.2\left(\mathrm{q}, \mathrm{CH}_{3} \mathrm{C}-8^{\prime}\right), 12.5$ (q, $\left.\mathrm{CH}_{3} \mathrm{C}-10^{\prime}\right), 9.7$ (q, C-1), 8.1 (q, C-5 or $\left.\mathrm{CH}_{3} \mathrm{C}-9^{\prime}\right), 8.0$ (q, C5 or $\left.\mathrm{CH}_{3} \mathrm{C}-9^{\prime}\right), 6.5\left(\mathrm{q}, \mathrm{CH}_{3} \mathrm{CC}-3^{\prime}\right), 2.2\left(\mathrm{q} \times 3, \mathrm{CH}_{3} \mathrm{Si}\right)$

LRMS (EI), $m / z$ (relative intensity): 384 ([M] $\left.{ }^{+}, 5\right), 259$ (60), 203 (18), 187 (21), 169 (67), 101 (19), 75 (17), 73 (37), 57 (100)

HRMS $\mathrm{m} / 2$ calcd for $\mathrm{C}_{20} \mathrm{H}_{30} \mathrm{O}_{5} \mathrm{Si}: 384.2332$; found: 384.2334 (EI).

\section{$(R)-2-[(1 R, 3 R, 5 S, 7 R, 8 R, 9 R, 10 R)-3$-Ethyl-8,9,10-trimethyl-5-[(S)-1-methyl-2-}

(phenylmethoxy)ethyl]-1-trimethylsilyloxy-2,4,6-trioxatricyclo[3.3.1.1 $\left.{ }^{3,7}\right] \mathrm{dec}-5$-yl]propanal (ent-167).

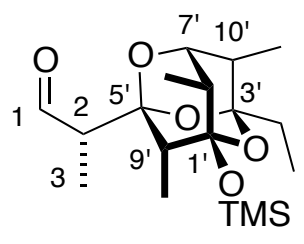

ent-167

Imidazole (552 mg, $8.11 \mathrm{mmol}$ ) was added to a stirred solution of aldehyde ent-10-epi-167 (419 $\mathrm{mg}, 1.18 \mathrm{mmol})$ in $\mathrm{CHCl}_{3}(14.8 \mathrm{~mL})$ that was previously neutralized by passing through basic alumina. After stirring at $40{ }^{\circ} \mathrm{C}$ for 1 day, the mixture was diluted with ethyl acetate, washed sequentially with $1 \%$ aq citric acid (x3), saturated aq $\mathrm{NaHCO}_{3}$ and brine, dried over $\mathrm{Na}_{2} \mathrm{SO}_{4}$, concentrated, and fractionated by FCC (5\% diethyl ether in hexanes) to yield the titled 
compound (62 mg, 14\%; dr 16-18) and recovered ent-10-epi-167 (338 mg, 80\%; dr 16-18). The latter fraction was re-subjected to the isomerization conditions and after a total of six isomerization cycles, recovered ent-10-epi-167 (119 mg, 28\%; dr 16-18) and the titled compound were obtained (208 mg, 49\%; dr 16-18). A similar experiment conducted in $\mathrm{CDCl}_{3}$ for several days resulted in a 4:1 ratio of ent-10-epi-167 and ent-167, respectively. $[\alpha]_{\mathrm{D}}+5\left(c 0.5, \mathrm{CHCl}_{3}\right)$

IR $v_{\max }: 1727 \mathrm{~cm}^{-1}$

${ }^{1} \mathbf{H}$ NMR $\left(500 \mathrm{MHz}, \mathrm{CDCl}_{3}\right)$ \&: $9.74(1 \mathrm{H}, \mathrm{d}, J=2.5 \mathrm{~Hz}, \mathrm{HC}-1), 3.80\left(1 \mathrm{H}, \mathrm{d}, J=3 \mathrm{~Hz}, \mathrm{HC}-7^{\prime}\right)$, $2.62(1 \mathrm{H}, \mathrm{dq}, J=2.5,7 \mathrm{~Hz}, \mathrm{HC}-2), 2.13(1 \mathrm{H}, \mathrm{dq}, J=3.5,7 \mathrm{~Hz}, \mathrm{HC}-10 '), 2.03-1.99(2 \mathrm{H}, \mathrm{m}, \mathrm{HC}-$ 8', HC-9'), $1.66\left(1 \mathrm{H}, \mathrm{dq}, J=14,7.5 \mathrm{~Hz}, \mathrm{HCC}-3^{\prime}\right), 1.56\left(1 \mathrm{H}, \mathrm{dq}, J=14,7.5 \mathrm{~Hz}, \mathrm{HCC}-3^{\prime}\right), 1.15$ $\left(3 \mathrm{H}, \mathrm{d}, J=7 \mathrm{~Hz}, \mathrm{H}_{3} \mathrm{C}-3\right), 1.05\left(3 \mathrm{H}, \mathrm{d}, J=7 \mathrm{~Hz}, \mathrm{H}_{3} \mathrm{CC}-8^{\prime}\right), 0.96\left(3 \mathrm{H}, \mathrm{t}, J=7.5 \mathrm{~Hz}, \mathrm{H}_{3} \mathrm{CCC}-3^{\prime}\right)$, $\left.0.92\left(3 \mathrm{H}, \mathrm{d}, J=7 \mathrm{~Hz}, \mathrm{H}_{3} \mathrm{CC}-10^{\prime}\right), 0.91\left(3 \mathrm{H}, \mathrm{d}, J=6.5 \mathrm{~Hz}, \mathrm{H}_{3} \mathrm{CC}-9\right)^{\prime}\right), 0.16\left(9 \mathrm{H}, \mathrm{s}, \mathrm{H}_{3} \mathrm{CSi} \times 3\right)$

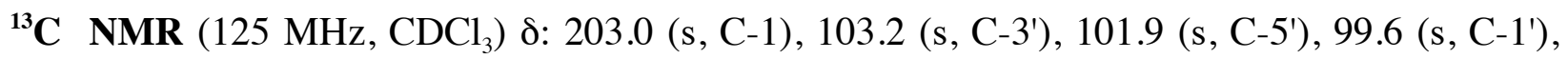
78.6 (d, C-7'), 52.6 (d, C-2), 37.6 (d, C-10'), 37.0 (d, C-9'), 36.7 (d, C-8'), 29.7 (t, $\left.\mathrm{CH}_{2} \mathrm{C}-3^{\prime}\right), 13.3$ (q, $\left.\mathrm{CH}_{3} \mathrm{C}-8^{\prime}\right), 12.7$ (q, $\left.\mathrm{CH}_{3} \mathrm{C}-10^{\prime}\right), 7.9$ (q, $\left.\mathrm{CH}_{3} \mathrm{C}-9^{\prime}\right), 7.5$ (q, C-3), 6.4 (q, $\mathrm{CH}_{3} \mathrm{CC}-3$ '), 2.2 (q ×3, $\left.\mathrm{CH}_{3} \mathrm{Si}\right)$

LRMS (EI), $m / z$ (relative intensity): 356 ([M] $\left.]^{+}, 7\right), 231$ (49), 187 (29), 141 (21), 101 (25), 73 (31), $71(21), 69(27), 57(100)$

HRMS $\mathrm{m} / \mathrm{z}$ calcd for $\mathrm{C}_{18} \mathrm{H}_{32} \mathrm{O}_{5} \mathrm{Si}$ : 356.2019; found: 356.2019 (EI). 
$\left(2 R, 3 R^{*}\right)-2-[(1 R, 3 R, 5 S, 7 R, 8 R, 9 R, 10 R)-3-E t h y l-8,9,10$-trimethyl-1-trimethylsilyloxy-2,4,6-

trioxatricyclo[3.3.1.1 $\left.{ }^{3,7}\right]$ dec-5-yl]pentan-3-ol (ent-170).

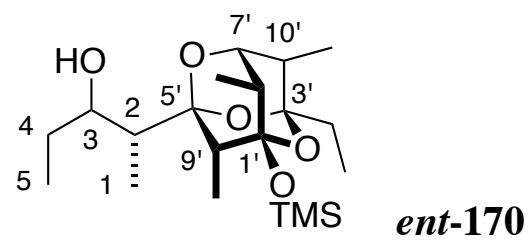

EtMgBr (3 M in diethyl ether; $0.075 \mathrm{~mL}, 0.23 \mathrm{mmol}$ ) was added to a stirred solution of aldehyde ent-167 (62 $\mathrm{mg}, 0.17 \mathrm{mmol})$ in THF $(3.4 \mathrm{~mL})$ at $-78{ }^{\circ} \mathrm{C}$ under argon. The reaction was monitored by TLC and additional EtMgBr solution (ca. $0.01 \mathrm{~mL}$ ) was added every $10 \mathrm{~min}$. After $50 \mathrm{~min}$, the reaction was quenched by addition of phosphates buffer $(\mathrm{pH}=7 ; 1 \mathrm{~mL})$, diluted with ethyl acetate and washed with phosphate buffer $(\mathrm{pH}=7)$. The aqueous layer was extracted with ethyl acetate and the combined organic layers were dried over $\mathrm{Na}_{2} \mathrm{SO}_{4}$, and concentrated to yield the titled compound as a 4:1 mixture of diastereomers $(66 \mathrm{mg}, 99 \%)$. $[\alpha]_{\mathrm{D}}+5\left(c 0.45, \mathrm{CHCl}_{3}\right)$

IR $v_{\max }: 3540 \mathrm{~cm}^{-1}$

${ }^{1} \mathbf{H}$ NMR $\left(500 \mathrm{MHz}, \mathrm{CDCl}_{3}\right) \delta$ (major diastereomer only): $3.82\left(1 \mathrm{H}, \mathrm{d}, J=3.5 \mathrm{~Hz}, \mathrm{HC}-7^{\prime}\right), 3.79$ $(1 \mathrm{H}$, ap t $J=7 \mathrm{~Hz}, \mathrm{HC}-2), 3.31(1 \mathrm{H}, \mathrm{s}, \mathrm{HO}), 2.18(1 \mathrm{H}, \mathrm{q}, J=6.5 \mathrm{~Hz}, \mathrm{HC}-9), 2.08(1 \mathrm{H}, \mathrm{dq}, J=$ 3.5, $\left.7 \mathrm{~Hz}, \mathrm{HC}-10^{\prime}\right), 1.98\left(1 \mathrm{H}\right.$, br q, $\left.J=7 \mathrm{~Hz}, \mathrm{HC}-8^{\prime}\right), 1.82(1 \mathrm{H}, \mathrm{q}, J=7 \mathrm{~Hz}, \mathrm{HC}-2), 1.71-1.49$ (3H, m, $\mathrm{H}_{2} \mathrm{CC}-3$ ' , HC-4), 1.35 (1H, ddq, $\left.J=7,14,7 \mathrm{~Hz}, \mathrm{HC}-4\right), 1.08$ (3H, d, $J=7 \mathrm{~Hz}, \mathrm{H}_{3} \mathrm{CC}-8$ '), $0.96\left(3 \mathrm{H}, \mathrm{d}, J=7 \mathrm{~Hz}, \mathrm{H}_{3} \mathrm{C}-1\right), 0.94\left(3 \mathrm{H}, \mathrm{t}, J=7.5 \mathrm{~Hz}, \mathrm{H}_{3} \mathrm{CCC}-3{ }^{\prime}\right), 0.90\left(3 \mathrm{H}, \mathrm{d}, J=7 \mathrm{~Hz}, \mathrm{H}_{3} \mathrm{CC}-\right.$ $\left.10^{\prime}\right), 0.89\left(3 \mathrm{H}, \mathrm{t}, J=6 \mathrm{~Hz}, \mathrm{H}_{3} \mathrm{C}-5\right), 0.87\left(3 \mathrm{H}, \mathrm{d}, J=6.5 \mathrm{~Hz}, \mathrm{H}_{3} \mathrm{CC}-9{ }^{\prime}\right), 0.16\left(9 \mathrm{H}, \mathrm{s}, \mathrm{H}_{3} \mathrm{CSi} \times 3\right)$

${ }^{13} \mathbf{C}$ NMR (125 MHz, $\mathrm{CDCl}_{3}$ ) $\delta$ (major diastereomer only): 104.7 (s, C-5'), 102.6 (s, C-3'), 99.7 (s, C-1'), 78.7 (d, C-7'), 70.8 (d, C-3), 40.0 (d, C-2), 37.0 (d, C-10'), 36.9 (d, C-8'), 35.8 (d, C-9'), 
29.6 (t, $\left.\mathrm{CH}_{2} \mathrm{C}-3^{\prime}\right), 27.4$ (t, C-4), 13.5 (q, $\left.\mathrm{CH}_{3} \mathrm{C}-8^{\prime}\right), 12.6$ (q, $\left.\mathrm{CH}_{3} \mathrm{C}-10^{\prime}\right), 10.7$ (q, C-5), 7.9 (q, $\left.\mathrm{CH}_{3} \mathrm{C}-9^{\prime}\right), 6.5\left(\mathrm{q}, \mathrm{CH}_{3} \mathrm{CC}-3\right.$ '), $4.5(\mathrm{q}, \mathrm{C}-1), 2.2\left(\mathrm{q} \times 3, \mathrm{CH}_{3} \mathrm{Si}\right)$

LRMS (CI, $\mathrm{NH}_{3}$ ), m/z (relative intensity): 387 ([M+1] $\left.]^{+}, 7\right), 329$ (25), 298 (19), 297 (100), 243 (25), 97 (7), 90 (14)

HRMS $m / z$ calcd for $\mathrm{C}_{20} \mathrm{H}_{38} \mathrm{O}_{5} \mathrm{Si}+\mathrm{H}: 387.2567$; found: 387.2556 (CI).

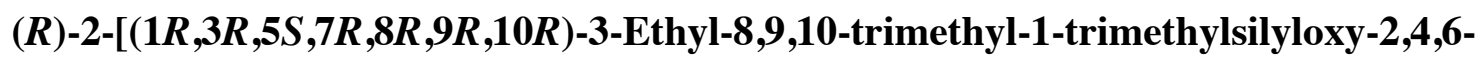
trioxatricyclo[3.3.1.1 $\left.{ }^{3,7}\right]$ dec-5-yl]pentan-3-one (ent-95).

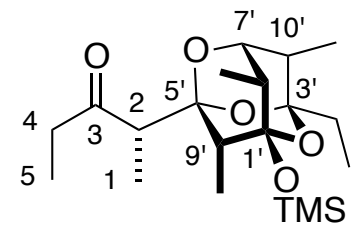

ent-95

IBX (217 mg, $0.775 \mathrm{mmol})$ was added to a stirred solution of ent-170 (148 $\mathrm{mg}, 0.382 \mathrm{mmol})$ in dry DMSO $(6.4 \mathrm{~mL})$ at room temperature under argon. After $14 \mathrm{~h}$, the reaction mixture was diluted with ethyl acetate, washed sequentially with saturated aq $\mathrm{NaHCO}_{3}$, distilled water and brine, dried over $\mathrm{Na}_{2} \mathrm{SO}_{4}$, concentrated, and fractionated by FCC (10\% ethyl acetate in hexane) to yield the titled compound $(130 \mathrm{mg}, 87 \%)[\alpha]_{\mathrm{D}}-20\left(c 0.4, \mathrm{CHCl}_{3}\right)$

IR $v_{\max }: 2980,2940,1705,1249,900,878,843 \mathrm{~cm}^{-1}$

${ }^{1} \mathbf{H}$ NMR $\left(500 \mathrm{MHz}, \mathrm{CDCl}_{3}\right) \delta: 3.81(1 \mathrm{H}, \mathrm{d}, J=3.5 \mathrm{~Hz}, \mathrm{HC}-7$ ') $2.81(1 \mathrm{H}, \mathrm{q}, J=7 \mathrm{~Hz}, \mathrm{HC}-2)$, $2.62(1 \mathrm{H}, \mathrm{dq}, J=18,7.5 \mathrm{~Hz}, \mathrm{HC}-4), 2.48(1 \mathrm{H}, \mathrm{dq}, J=18,7.5 \mathrm{~Hz}, \mathrm{HC}-4), 2.08(1 \mathrm{H}, \mathrm{dq}, J=3.5,7$ Hz, HC-10'), $1.97\left(1 \mathrm{H}\right.$, br q, $\left.J=7 \mathrm{~Hz}, \mathrm{HC}-8^{\prime}\right), 1.87\left(1 \mathrm{H}, \mathrm{q}, J=6.5 \mathrm{~Hz}, \mathrm{HC}-9^{\prime}\right), 1.62(1 \mathrm{H}, \mathrm{dq}, J=$ 14, $\left.7.5 \mathrm{~Hz}, \mathrm{HCC}-3^{\prime}\right), 1.53\left(1 \mathrm{H}, \mathrm{dq}, J=14,7.5 \mathrm{~Hz}, \mathrm{HCC}-3^{\prime}\right), 1.21\left(3 \mathrm{H}, \mathrm{d}, J=7 \mathrm{~Hz}, \mathrm{H}_{3} \mathrm{C}-1\right), 1.04$ $\left(3 \mathrm{H}, \mathrm{d}, J=7 \mathrm{~Hz}, \mathrm{H}_{3} \mathrm{CC}-8^{\prime}\right), 1.00\left(3 \mathrm{H}, \mathrm{t}, J=7.5 \mathrm{~Hz}, \mathrm{H}_{3} \mathrm{C}-5\right), 0.94\left(3 \mathrm{H}, \mathrm{t}, J=7.5 \mathrm{~Hz}, \mathrm{H}_{3} \mathrm{CCC}-3^{\prime}\right)$, $0.93\left(3 \mathrm{H}, \mathrm{d}, J=6.5 \mathrm{~Hz}, \mathrm{H}_{3} \mathrm{CC}-9 '\right), 0.90\left(3 \mathrm{H}, \mathrm{d}, J=7 \mathrm{~Hz}, \mathrm{H}_{3} \mathrm{CC}-10\right)$ ) $0.15\left(9 \mathrm{H}, \mathrm{s}, \mathrm{H}_{3} \mathrm{CSi} \times 3\right)$ 
${ }^{13} \mathrm{C}$ NMR (125 MHz, $\mathrm{CDCl}_{3}$ ) $\delta: 212.2$ (s, C-3), 103.1 (s, C-3'), 101.5 (s, C-5'), 99.8 (s, C-1'), 78.5 (d, C-6'), 53.2 (d, C-2), 37.3 (d, C-9'), 37.2 (d, C-10'), 36.8 (d, C-8'), 33.9 (t, C-4), 29.7 (t, $\left.\mathrm{CH}_{2} \mathrm{C}-3^{\prime}\right), 13.4$ (q, $\mathrm{CH}_{3} \mathrm{C}-8$ '), 12.6 (q, $\left.\mathrm{CH}_{3} \mathrm{C}-10^{\prime}\right), 10.4$ (q, C-1), 8.1 (q, C-5 or $\left.\mathrm{CH}_{3} \mathrm{C}-9^{\prime}\right), 8.0$ (q, C-5 or $\left.\mathrm{CH}_{3} \mathrm{C}-9^{\prime}\right), 6.5\left(\mathrm{q}, \mathrm{CH}_{3} \mathrm{CC}-3^{\prime}\right), 2.2\left(\mathrm{q} \times 3, \mathrm{CH}_{3} \mathrm{Si}\right)$

LRMS (EI), m/z (relative intensity): 384 ([M] $\left.]^{+}, 9\right), 259$ (45), 239 (16), 197 (17), 187 (23), 169 (61), $73(33), 57(100)$

HRMS $m / z$, calcd for $\mathrm{C}_{20} \mathrm{H}_{36} \mathrm{O}_{5} \mathrm{Si}$ : 384.2332; found: 384.2328 (EI).

ent-(10R,12R,13S)-11-Didehydro-13-dihydro-7-O-(trimethylsilyl)caloundrin B (185).

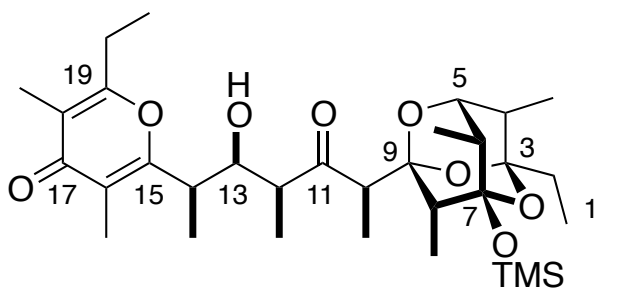

185

9-BBNOTf $(0.5 \mathrm{M}$ in hexane; $0.31 \mathrm{~mL}, 0.16 \mathrm{mmol})$ was added to a stirred solution of $\mathrm{Et}_{3} \mathrm{~N}$ $(0.024 \mathrm{~mL}, 17 \mathrm{mg}, 0.17 \mathrm{mmol})$ in ethyl ether $(1 \mathrm{~mL})$ at $-78{ }^{\circ} \mathrm{C}$ under argon. After $10 \mathrm{~min}$, a solution of ketone ent-10-epi-95 $(30 \mathrm{mg}, 0.078 \mathrm{mmol})$ in ether $(0.3 \mathrm{~mL}$ plus $2 \times 0.1 \mathrm{~mL}$ rinses $)$ was added via syringe. After $2 \mathrm{~h}$, a solution of freshly prepared aldehyde ( \pm )-30 (49 $\mathrm{mg}, 0.23$ mmol) via syringe in ether $(0.3 \mathrm{~mL})$ was added. After $2 \mathrm{~h}$, the reaction was quenched by sequential addition of phosphate buffer $(\mathrm{pH}=7 ; 3 \mathrm{~mL})$, methanol $(0.5 \mathrm{~mL})$ and $30 \% \mathrm{aq}_{2} \mathrm{O}_{2}(0.5$ $\mathrm{mL}$ ) with vigorous stirring. The mixture was warmed to $0{ }^{\circ} \mathrm{C}$ and, after $10 \mathrm{~min}$, was extracted with $\mathrm{CH}_{2} \mathrm{Cl}_{2}$. The combined organic layers were dried over $\mathrm{Na}_{2} \mathrm{SO}_{4}$, concentrated, and fractionated by FCC (20-50\% ethyl acetate in hexane) to provide the titled compound (34.5 $\mathrm{mg}$, $74 \%) \cdot[\alpha]_{\mathrm{D}}-39\left(c 1.9, \mathrm{CHCl}_{3}\right)$ 
IR $v_{\max }: 3438,1715,1656,1615 \mathrm{~cm}^{-1}$

${ }^{1} \mathbf{H}$ NMR $\left(500 \mathrm{MHz}, \mathrm{CDCl}_{3}\right) \delta: 4.32(1 \mathrm{H}, \mathrm{d}, J=10 \mathrm{~Hz}, \mathrm{HC}-13), 3.62(1 \mathrm{H}, \mathrm{d}, J=3 \mathrm{~Hz}, \mathrm{HC}-5)$, $3.07(1 \mathrm{H}, \mathrm{dq}, J=10,7 \mathrm{~Hz}, \mathrm{HC}-14), 3.05-2.96(2 \mathrm{H}, \mathrm{m}, \mathrm{HO}, \mathrm{HC}-10), 2.92(1 \mathrm{H}$, br q, $J=7 \mathrm{~Hz}$, HC-12), $2.61(1 \mathrm{H}, \mathrm{dq}, J=15,7.5 \mathrm{~Hz}, \mathrm{HC}-20), 2.48(1 \mathrm{H}, \mathrm{dq}, J=15,7.5 \mathrm{~Hz}, \mathrm{HC}-20), 1.98(3 \mathrm{H}, \mathrm{s}$, $\left.\mathrm{H}_{3} \mathrm{CC}-16\right), 1.95-1.87$ (2H, m, HC-6, HC-8), 1.92 (3H, s, $\left.\mathrm{H}_{3} \mathrm{CC}-18\right), 1.61-1.42\left(2 \mathrm{H}, \mathrm{m}, \mathrm{H}_{2} \mathrm{C}-2\right.$, HC-4), $1.34\left(3 \mathrm{H}, \mathrm{d}, J=7 \mathrm{~Hz}, \mathrm{H}_{3} \mathrm{CC}-14\right), 1.18\left(3 \mathrm{H}, \mathrm{t}, J=7.5 \mathrm{~Hz}, \mathrm{H}_{3} \mathrm{C}-21\right), 1.14(3 \mathrm{H}, \mathrm{d}, J=7.5$ $\left.\mathrm{Hz}, \mathrm{H}_{3} \mathrm{CC}-12\right), 1.03\left(3 \mathrm{H}, \mathrm{d}, J=7 \mathrm{~Hz}, \mathrm{H}_{3} \mathrm{CC}-10\right), 1.00\left(3 \mathrm{H}, \mathrm{d}, J=7 \mathrm{~Hz}, \mathrm{H}_{3} \mathrm{CC}-6\right), 0.92(3 \mathrm{H}, \mathrm{d}, J=$ $\left.6.5 \mathrm{~Hz}, \mathrm{H}_{3} \mathrm{CC}-8\right), 0.82\left(3 \mathrm{H}, \mathrm{t}, J=7.5 \mathrm{~Hz}, \mathrm{H}_{3} \mathrm{C}-1\right), 0.76\left(3 \mathrm{H}, \mathrm{d}, J=7 \mathrm{~Hz}, \mathrm{H}_{3} \mathrm{CC}-4\right), 0.14(9 \mathrm{H}, \mathrm{s}$, $\left.\mathrm{H}_{3} \mathrm{CSi} \times 3\right)$

${ }^{13}$ C NMR (125 MHz, $\mathrm{CDCl}_{3}$ ) ): 215.4 (s, C-11), 179.7 (s, C-17), 164.4 (s, C-15 or C-19), 164.3 (s, C-15 or C-19), 119.1 (s, C-16), 118.1 (s, C-18), 103.4 (s, C-9), 103.0 (s, C-3), 99.6 (s, C-7), 78.4 (d, C-5), 71.9 (d, C-13), 48.6 (d, C-12), 48.5 (d, C-10), 38.4 (d, C-14), 38.4 (d, C-4), 36.6 (d, C-6), 35.6 (d, C-8), 29.5 (t, C-2), 24.9 (t, C-20), 16.0 (q, $\left.\mathrm{CH}_{3} \mathrm{C}-14\right), 13.1$ (q, $\left.\mathrm{CH}_{3} \mathrm{C}-6\right), 12.7$ (q, $\left.\mathrm{CH}_{3} \mathrm{C}-4\right), 11.5$ (q, C-21), 10.1 (q, $\left.\mathrm{CH}_{3} \mathrm{C}-12\right), 10.0$ (q, $\left.\mathrm{CH}_{3} \mathrm{C}-10\right), 9.9$ (q, $\left.\mathrm{CH}_{3} \mathrm{C}-16\right), 9.8$ (q, $\left.\mathrm{CH}_{3} \mathrm{C}-18\right), 7.9\left(\mathrm{q}, \mathrm{CH}_{3} \mathrm{C}-8\right), 6.0(\mathrm{q}, \mathrm{C}-1), 2.1\left(\mathrm{q} \times 3, \mathrm{CH}_{3} \mathrm{Si}\right)$

LRMS (EI), m/z (relative intensity): 592 ([M] $\left.]^{+}, 4\right), 467$ (22), 259 (29), 180 (40), 179 (41), 73 (37), $57(100)$

HRMS $\mathrm{m} / \mathrm{z}$ calcd for $\mathrm{C}_{32} \mathrm{H}_{52} \mathrm{O}_{8} \mathrm{Si}$ : 592.3432; found: 592.3422 (EI). 
ent-(10R,11S,12R,13R)-13-Dihydro-7-O-(trimethylsilyl)caloundrin B (189).

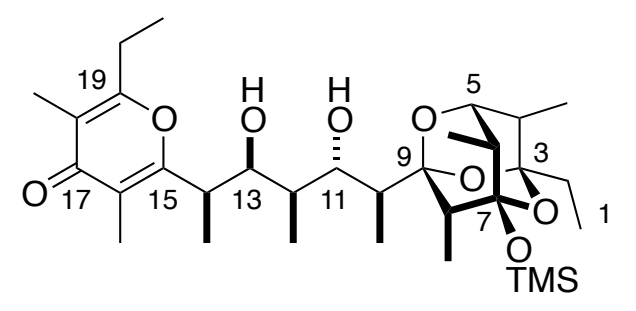

189

$\mathrm{NaBH}(\mathrm{OAc})_{3}(32 \mathrm{mg}, 0.15 \mathrm{mmol})$ and acetic acid $(77 \mathrm{mg}, 73 \mathrm{uL}, 1.3 \mathrm{mmol})$ were added sequentially to a stirred solution of aldol adduct $185(18 \mathrm{mg}, 0.030 \mathrm{mmol})$ in THF $(0.7 \mathrm{~mL})$ under argon at room temperature. After $3 \mathrm{~h}$, distilled water $(1.3 \mathrm{~mL})$ was added. The mixture was diluted with ethyl acetate, washed sequentially with saturated aq $\mathrm{NaHCO}_{3}$ and brine, dried over $\mathrm{Na}_{2} \mathrm{SO}_{4}$, concentrated, and fractionated by FCC (50\% ethyl acetate in hexane) to yield the desired product $(14 \mathrm{mg}, 78 \%) .[\alpha]_{\mathrm{D}}-5\left(c 1.4, \mathrm{CHCl}_{3}\right)$

IR $v_{\max }: 3440,1655,1604 \mathrm{~cm}^{-1}$

${ }^{1} \mathbf{H}$ NMR (500 MHz, $\mathrm{CDCl}_{3}$ ) $\delta: 4.92$ (1H, br s, HOC-11), 4.35 (1H, br s, HOC-13), 4.16 (1H, d, $J=10 \mathrm{~Hz}, \mathrm{HC}-13), 3.98(1 \mathrm{H}, \mathrm{dd}, J=1.5,9 \mathrm{~Hz}, \mathrm{HC}-11), 3.81(1 \mathrm{H}, \mathrm{d}, J=3 \mathrm{~Hz}, \mathrm{HC}-5), 3.09(1 \mathrm{H}$, $\mathrm{dq}, J=10,6.5 \mathrm{~Hz}, \mathrm{HC}-14), 2.64(1 \mathrm{H}, \mathrm{dq}, J=15,7.5 \mathrm{~Hz}, \mathrm{HC}-20), 2.49(1 \mathrm{H}, \mathrm{dq}, J=15,7.5 \mathrm{~Hz}$, HC-20), 2.10-1.97 (4H, m, HC-4,HC-6, HC-8, HC-10), 2.00 (3H, s, H $\left.\mathrm{HC}_{3}-16\right), 1.92$ (3H, s, $\left.\mathrm{H}_{3} \mathrm{CC}-18\right), 1.71-1.62(1 \mathrm{H}, \mathrm{dq}, J=14.5,7.5 \mathrm{~Hz}, \mathrm{HC}-2), 1.54-1.46$ (2H, m, HC-2, HC-12), 1.35 $\left(3 \mathrm{H}, \mathrm{d}, J=6.5 \mathrm{~Hz}, \mathrm{H}_{3} \mathrm{CC}-14\right), 1.21\left(3 \mathrm{H}, \mathrm{t}, J=7.5 \mathrm{~Hz}, \mathrm{H}_{3} \mathrm{C}-21\right), 1.07\left(3 \mathrm{H}, \mathrm{d}, J=7 \mathrm{~Hz}, \mathrm{H}_{3} \mathrm{CC}-12\right)$, $1.03\left(3 \mathrm{H}, \mathrm{d}, J=7 \mathrm{~Hz}, \mathrm{H}_{3} \mathrm{CC}-6\right), 0.93\left(9 \mathrm{H}, \mathrm{d}, J=6.5 \mathrm{~Hz}, \mathrm{H}_{3} \mathrm{CC}-8\right), 0.92\left(3 \mathrm{H}, \mathrm{t}, J=7.5 \mathrm{~Hz}, \mathrm{H}_{3} \mathrm{C}-\right.$ 1), $0.90\left(3 \mathrm{H}, \mathrm{d}, J=7 \mathrm{~Hz}, \mathrm{H}_{3} \mathrm{CC}-4\right), 0.57\left(3 \mathrm{H}, \mathrm{d}, J=7 \mathrm{~Hz}, \mathrm{H}_{3} \mathrm{CC}-10\right), 0.16\left(9 \mathrm{H}, \mathrm{s}, \mathrm{H}_{3} \mathrm{CSi} \times 3\right)$

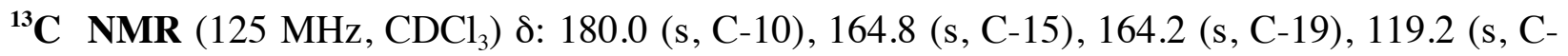
16), 118.3 (s, C-18), 106.1 (s, C-9), 103.6 (s, C-3), 99.7 (s, C-7), 78.4 (d, C-5), 78.0 (d, C-11), 72.5 (d, C-13), 40.0 (d, C-10), 39.6 (d, C-14), 37.8 (d, C-4), 36.6 (d, C-6), 35.7 (d, C-8 or C-12), 
35.6 (d, C-8 or C-12), 29.6 (t, C-2), 25.0 (t, C-20), 15.7 (q, $\left.\mathrm{CH}_{3} \mathrm{C}-14\right), 13.2\left(\mathrm{q}, \mathrm{CH}_{3} \mathrm{C}-6\right), 12.6$ (q, $\left.\mathrm{CH}_{3} \mathrm{C}-4\right), 11.8$ (q, $\left.\mathrm{CH}_{3} \mathrm{C}-12\right), 11.4$ (q, $\left.\mathrm{CH}_{3} \mathrm{C}-21\right), 10.1$ (q, $\mathrm{CH}_{3} \mathrm{C}-16$ ), 9.9 (q, $\mathrm{CH}_{3} \mathrm{C}-10$ ), 9.7 (q, $\left.\mathrm{CH}_{3} \mathrm{C}-18\right), 7.5\left(\mathrm{q}, \mathrm{CH}_{3} \mathrm{C}-8\right), 6.3(\mathrm{q}, \mathrm{C}-1), 2.1\left(\mathrm{q} \times 3, \mathrm{CH}_{3} \mathrm{Si}\right)$

LRMS (EI), m/z (relative intensity): 594 ([M] $\left.{ }^{+}, 5\right), 525$ (10), 469 (24), 267 (14), 209 (12), 181 (17), 180 (100), $153(12), 73(26), 57$ (46)

HRMS $m / z$ calcd for $\mathrm{C}_{32} \mathrm{H}_{54} \mathrm{O}_{8} \mathrm{Si}$ : 594.3588; found: 594.3592 (EI).

ent-(10R,12S,13S)-11-Didehydro-13-dihydro-7-O-(trimethylsilyl)caloundrin B (186)

\section{0-epi-anti-aldol-A}

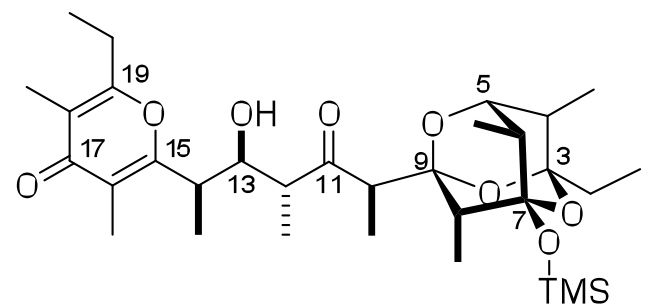

186

$[\alpha]_{\mathrm{D}}-90\left(\right.$ c $\left.0.23, \mathrm{CHCl}_{3}\right)$

IR $v_{\max }: 3364,1703,1654,1612,1597(\mathrm{sh}) \mathrm{cm}^{-1}$

${ }^{1} \mathbf{H}$ NMR $\left(500 \mathrm{MHz}, \mathrm{CDCl}_{3}\right) \delta: 3.82(1 \mathrm{H}, \mathrm{ddd}, J=4,8,9 \mathrm{~Hz}, \mathrm{HC}-13), 3.61(1 \mathrm{H}, \mathrm{dd}, J=3.5,1$ Hz, HC-5), 3.38 (1H, dq, $J=8,7 \mathrm{~Hz}, \mathrm{HC}-14), 3.04(1 \mathrm{H}, \mathrm{dq}, J=4,7.5 \mathrm{~Hz}, \mathrm{HC}-12), 2.98(1 \mathrm{H}, \mathrm{q}$, $J=7 \mathrm{~Hz}, \mathrm{HC}-10), 2.89(1 \mathrm{H}, \mathrm{d}, J=9 \mathrm{~Hz}, \mathrm{HO}), 2.63-2.53\left(2 \mathrm{H}, \mathrm{m}, \mathrm{H}_{2} \mathrm{C}-20\right), 1.97-1.86(2 \mathrm{H}, \mathrm{m}$, HC-6, HC-8), 1.93 (3H, s, $\left.\mathrm{H}_{3} \mathrm{CC}-18\right), 1.88$ (3H, s, $\left.\mathrm{H}_{3} \mathrm{CC}-16\right), 1.66-1.47$ (2H, m, HC-2, HC-4), 1.40-1.29 (1H, m, HC-2), 1.31 (3H, d, $\left.J=7 \mathrm{~Hz}, \mathrm{H}_{3} \mathrm{CC}-14\right), 1.28\left(3 \mathrm{H}, \mathrm{d}, J=7.5 \mathrm{~Hz}, \mathrm{H}_{3} \mathrm{CC}-12\right)$, $1.20\left(3 \mathrm{H}, \mathrm{t}, J=7.5 \mathrm{~Hz}, \mathrm{H}_{3} \mathrm{C}-21\right), 1.02\left(3 \mathrm{H}, \mathrm{d}, J=7 \mathrm{~Hz}, \mathrm{H}_{3} \mathrm{CC}-10\right), 1.01\left(3 \mathrm{H}, \mathrm{d}, J=7 \mathrm{~Hz}, \mathrm{H}_{3} \mathrm{CC}-\right.$ 6), $0.93\left(3 \mathrm{H}, \mathrm{d}, J=6.5 \mathrm{~Hz}, \mathrm{H}_{3} \mathrm{CC}-8\right), 0.86\left(3 \mathrm{H}, \mathrm{t}, J=7.5 \mathrm{~Hz}, \mathrm{H}_{3} \mathrm{C}-1\right), 0.74(3 \mathrm{H}, \mathrm{d}, J=7 \mathrm{~Hz}$, $\left.\mathrm{H}_{3} \mathrm{CC}-4\right), 0.14\left(9 \mathrm{H}, \mathrm{s}, \mathrm{H}_{3} \mathrm{CSi} \times 3\right)$ 
${ }^{13} \mathrm{C}$ NMR (125 MHz, $\mathrm{CDCl}_{3}$ ) $\delta: 215.1$ (s, C-11), 179.7 (s, C-17), 165.4 (s, C-15), 164.3 (s, C19), 118.8 (s, C-16), 118.1 (s, C-18), 103.7 (s, C-9), 103.2 (s, C-3), 99.7 (s, C-7), 78.1 (d, C-5), 76.7 (d, C-13), 49.7 (d, C-12), 48.5 (d, C-10), 39.7 (d, C-14), 37.5 (d, C-4), 36.5 (d, C-6), 35.8 (d, C-8), 29.5 (t, C-2), 24.0 (t, C-20), 16.7 (q, $\left.\mathrm{CH}_{3} \mathrm{C}-12\right), 15.1$ (q, $\left.\mathrm{CH}_{3} \mathrm{C}-14\right), 13.1$ (q, $\left.\mathrm{CH}_{3} \mathrm{C}-6\right)$, 12.5 (q, $\left.\mathrm{CH}_{3} \mathrm{C}-4\right), 11.4$ (q, C-21), 9.8 (q, $\left.\mathrm{CH}_{3} \mathrm{C}-18\right), 9.3$ (q $\left.\times 2, \mathrm{CH}_{3} \mathrm{C}-10, \mathrm{CH}_{3} \mathrm{C}-16\right), 8.1$ (q, $\left.\mathrm{CH}_{3} \mathrm{C}-8\right), 6.3(\mathrm{q}, \mathrm{C}-1), 2.1\left(\mathrm{q} \times 3, \mathrm{CH}_{3} \mathrm{Si}\right)$

LRMS (EI), m/z (relative intensity): 592 ([M] $\left.]^{+}, 9\right), 468$ (18), 467 (54), 349 (32), 181 (17), 180 (100), $179(19), 73(33), 57(49)$

HRMS $m / z$ calcd for $\mathrm{C}_{32} \mathrm{H}_{52} \mathrm{O}_{8} \mathrm{Si}$ : 592.3431; found: 592.3448 (EI).

ent-(10R,12R,13R)-11-Didehydro-13-dihydro-7-O-(trimethylsilyl)caloundrin B (188)

\section{0-epi-anti-aldol-B}

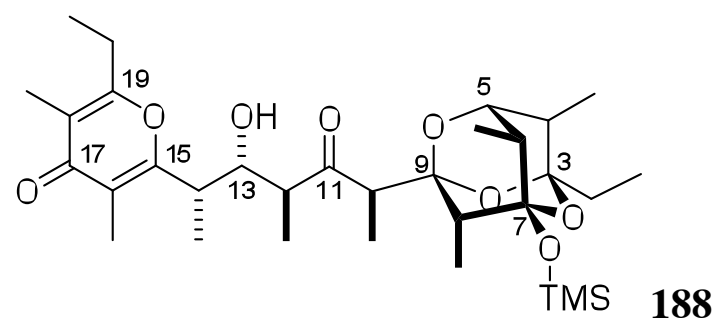

$\mathrm{Et}_{3} \mathrm{~N}(0.008 \mathrm{~mL}, 6 \mathrm{mg}, 0.06 \mathrm{mmol})$ and $\mathrm{BCl}\left(c-\mathrm{C}_{6} \mathrm{H}_{12}\right)_{2}(1 \mathrm{M}$ in hexane; $0.052 \mathrm{~mL}, 0.052 \mathrm{mmol})$ were added sequentially to a stirred solution of ent-10-epi-95 $(9 \mathrm{mg}, 0.023 \mathrm{mmol})$ in ether $(0.2$ $\mathrm{mL}$ ) at $0{ }^{\circ} \mathrm{C}$ under argon. After $1 \mathrm{~h}$, the reaction mixture was cooled at $-78^{\circ} \mathrm{C}$ and a solution of freshly prepared aldehyde $( \pm)-30(16 \mathrm{mg}, 0.078 \mathrm{mg})$ in ether $(0.25 \mathrm{~mL})$ was added. After $2 \mathrm{~h}$, the reaction was quenched by sequential addition of of phosphate buffer $(\mathrm{pH}=7,0.5 \mathrm{~mL}), \mathrm{MeOH}$ $(0.5 \mathrm{~mL})$, and $30 \%$ aq $\mathrm{H}_{2} \mathrm{O}_{2}(0.5 \mathrm{~mL})$ with vigorous stirring. After $10 \mathrm{~min}$ at $0{ }^{\circ} \mathrm{C}$, the mixture was extracted with $\mathrm{CH}_{2} \mathrm{Cl}_{2}$ and the combined organic layers were dried over $\mathrm{Na}_{2} \mathrm{SO}_{4}$, 
concentrated, and fractionated by PTLC (50\% ethyl acetate in hexane) to provide $\mathbf{1 8 6}$ (anti-aldol, $3 \mathrm{mg}, 16 \%)$ and $\mathbf{1 8 8}$ (anti-aldol, $9.3 \mathrm{mg}, 67 \%) .[\alpha]_{\mathrm{D}}-60\left(c 0.9, \mathrm{CHCl}_{3}\right)$

IR $v_{\max }: 3379,1716,1651,1595 \mathrm{~cm}^{-1}$

${ }^{1} \mathbf{H}$ NMR $\left(500 \mathrm{MHz}, \mathrm{CDCl}_{3}\right) \delta: 3.83(1 \mathrm{H}, \mathrm{q}, J=6.5, \mathrm{~Hz}, \mathrm{HC}-13), 3.80(1 \mathrm{H}, \mathrm{br} \mathrm{d}, J=3 \mathrm{~Hz}, \mathrm{HC}-$ 5), $3.12(1 \mathrm{H}, \mathrm{dq}, J=6.5,7 \mathrm{~Hz}, \mathrm{HC}-12), 2.98(1 \mathrm{H}, \mathrm{q}, J=7 \mathrm{~Hz}, \mathrm{HC}-10), 2.91(1 \mathrm{H}, \mathrm{dq}, J=6.5,7$ $\mathrm{Hz}, \mathrm{HC}-14), 2.65(1 \mathrm{H}, \mathrm{d}, J=6.5 \mathrm{~Hz}, \mathrm{HO}), 2.60\left(2 \mathrm{H}\right.$, ap q, $\left.J=7.5 \mathrm{~Hz}, \mathrm{H}_{2} \mathrm{C}-20\right), 2.02-1.87(3 \mathrm{H}$, m, HC-4, HC-6, HC-8), 1.93 (3H, s, $\mathrm{H}_{3} \mathrm{CC}-16$ or $\left.\mathrm{H}_{3} \mathrm{CC}-18\right), 1.92$ (3H, s, $\mathrm{H}_{3} \mathrm{CC}-16$ or $\mathrm{H}_{3} \mathrm{CC}-18$ ), $1.65(1 \mathrm{H}, \mathrm{dq}, J=15,7.5 \mathrm{~Hz}, \mathrm{HC}-2), 1.44(1 \mathrm{H}, \mathrm{dq}, J=15,7.5 \mathrm{~Hz}, \mathrm{HC}-2), 1.30(3 \mathrm{H}, \mathrm{d}, J=7 \mathrm{~Hz}$, $\left.\mathrm{H}_{3} \mathrm{CC}-14\right), 1.20\left(3 \mathrm{H}, \mathrm{t}, J=7.5 \mathrm{~Hz}, \mathrm{H}_{3} \mathrm{C}-21\right), 1.13\left(3 \mathrm{H}, \mathrm{d}, J=7 \mathrm{~Hz}, \mathrm{H}_{3} \mathrm{CC}-12\right), 1.03(3 \mathrm{H}, \mathrm{d}, J=7$ $\left.\mathrm{Hz}, \mathrm{H}_{3} \mathrm{CC}-6\right), 1.00\left(3 \mathrm{H}, \mathrm{d}, J=7 \mathrm{~Hz}, \mathrm{H}_{3} \mathrm{CC}-10\right), 0.90\left(3 \mathrm{H}, \mathrm{t}, J=7.5 \mathrm{~Hz}, \mathrm{H}_{3} \mathrm{C}-1\right), 0.89(3 \mathrm{H}, \mathrm{d}, J=$ $\left.7 \mathrm{~Hz}, \mathrm{H}_{3} \mathrm{CC}-8\right), 0.86\left(3 \mathrm{H}, \mathrm{d}, J=7 \mathrm{~Hz}, \mathrm{H}_{3} \mathrm{CC}-4\right), 0.16\left(9 \mathrm{H}, \mathrm{s}, \mathrm{H}_{3} \mathrm{CSi} \times 3\right)$

${ }^{13} \mathrm{C}$ NMR (125 MHz, $\mathrm{CDCl}_{3}$ ) ): 216.9 (s, C-11), 179.7 (s, C-12), 164.9 (s, C-15), 164.3 (s, C19), 118.6 (s, C-18), 118.4 (s, C-16), 104.0 (s, C-9), 103.1 (s, C-3), 99.7 (s, C-7), 78.4 (d, C-5), 77.4 (d, C-13), 52.5 (d, C-10), 49.4 (d, C-12), 39.9 (d, C-14), 37.9 (d, C-4), 36.6 (d, C-6), 35.6 (d, C-8), 29.7 (t, C-2), 24.9 (t, C-20), 14.5 (q, $\left.\mathrm{CH}_{3} \mathrm{C}-12\right), 13.7$ (q, $\left.\mathrm{CH}_{3} \mathrm{C}-14\right), 13.2$ (q, $\left.\mathrm{CH}_{3} \mathrm{C}-6\right)$, 12.6 (q, $\left.\mathrm{CH}_{3} \mathrm{C}-4\right), 11.5$ (q, C-21), $9.72\left(\mathrm{q}, \mathrm{CH}_{3} \mathrm{C}-16\right.$ or $\left.\mathrm{CH}_{3} \mathrm{C}-18\right), 9.66$ (q, $\mathrm{CH}_{3} \mathrm{C}-16$ or $\left.\mathrm{CH}_{3} \mathrm{C}-18\right)$, $9.5\left(\mathrm{q}, \mathrm{CH}_{3} \mathrm{C}-10\right), 7.9\left(\mathrm{q}, \mathrm{CH}_{3} \mathrm{C}-8\right), 6.1(\mathrm{q}, \mathrm{C}-1), 2.2\left(\mathrm{q} \times 3, \mathrm{H}_{3} \mathrm{CSi}\right)$

LRMS (EI), $m / z$ (relative intensity): 592 ([M] $\left.{ }^{+}, 5\right), 467$ (45), 349 (28), 180 (100), 179 (54), 169 (15), $153(33), 73(36), 57(86)$

HRMS $\mathrm{m} / \mathrm{z}$ calcd for $\mathrm{C}_{32} \mathrm{H}_{52} \mathrm{O}_{8} \mathrm{Si}: 592.3431$; found: 592.3418 (EI). 
syn-aldol-A.

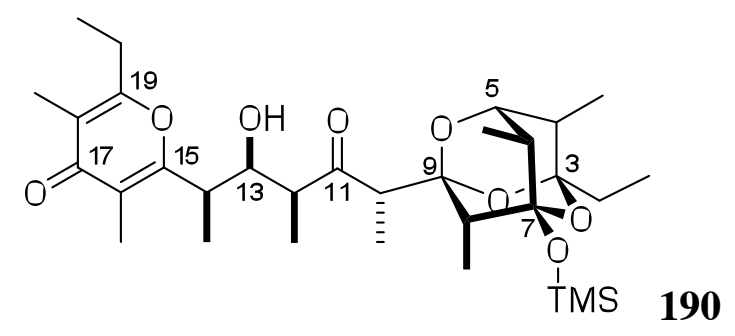

$[\alpha]_{\mathrm{D}}-15\left(c 0.2, \mathrm{CHCl}_{3}\right)$

IR $v_{\max }: 3421,1700,1653,1616 \mathrm{~cm}^{-1}$

${ }^{1} \mathbf{H}$ NMR (500 MHz, $\left.\mathrm{CDCl}_{3}\right) \delta: 4.08(1 \mathrm{H}, \mathrm{d}, J=10 \mathrm{~Hz}, \mathrm{HC}-13), 3.74(1 \mathrm{H}, \mathrm{d}, J=3.5 \mathrm{~Hz}, \mathrm{HC}-5)$, $1.19(1 \mathrm{H}$, br s, HO), $3.04(1 \mathrm{H}, \mathrm{dq}, J=10,7 \mathrm{~Hz}, \mathrm{HC}-14), 2.89(1 \mathrm{H}, \mathrm{q}, J=7 \mathrm{~Hz}, \mathrm{HC}-10), 2.78$ $(1 \mathrm{H}$, br q $, J=7 \mathrm{~Hz}, \mathrm{HC}-12), 2.67(1 \mathrm{H}, \mathrm{dq}, J=15,7.5 \mathrm{~Hz}, \mathrm{HC}-20), 2.51(1 \mathrm{H}, \mathrm{dq}, J=15,7.5 \mathrm{~Hz}$, HC-20), 2.08-1.90 (2H, m, HC-4, HC-6), 1.99 (3H, s, H $\left.{ }_{3} \mathrm{CC}-16\right), 1.95$ (3H, s, $\left.\mathrm{H}_{3} \mathrm{CC}-18\right), 1.76$ $(1 \mathrm{H}, \mathrm{s}, J=6.5 \mathrm{~Hz}, \mathrm{HC}-8), 1.68-1.42(2 \mathrm{H}, \mathrm{m}, \mathrm{HC}-2), 1.35\left(3 \mathrm{H}, \mathrm{d}, J=7 \mathrm{~Hz}, \mathrm{H}_{3} \mathrm{CC}-14\right), 1.20(3 \mathrm{H}$, $\left.\mathrm{t}, J=7.5 \mathrm{~Hz}, \mathrm{H}_{3} \mathrm{C}-21\right), 1.14\left(3 \mathrm{H}, \mathrm{d}, J=7 \mathrm{~Hz}, \mathrm{H}_{3} \mathrm{CC}-10\right), 1.09\left(3 \mathrm{H}, \mathrm{d}, J=7 \mathrm{~Hz}, \mathrm{H}_{3} \mathrm{CC}-12\right), 0.99$ $\left(3 \mathrm{H}, \mathrm{d}, J=7 \mathrm{~Hz}, \mathrm{H}_{3} \mathrm{CC}-6\right), 0.87\left(3 \mathrm{H}, \mathrm{t}, J=7.5 \mathrm{~Hz}, \mathrm{H}_{3} \mathrm{C}-1\right), 0.87\left(3 \mathrm{H}, \mathrm{d}, J=7 \mathrm{~Hz}, \mathrm{H}_{3} \mathrm{CC}-4\right), 0.81$ $\left(3 \mathrm{H}, \mathrm{d}, J=6.5 \mathrm{~Hz}, \mathrm{H}_{3} \mathrm{CC}-8\right), 0.14\left(9 \mathrm{H}, \mathrm{s}, \mathrm{H}_{3} \mathrm{CSi} \times 3\right)$

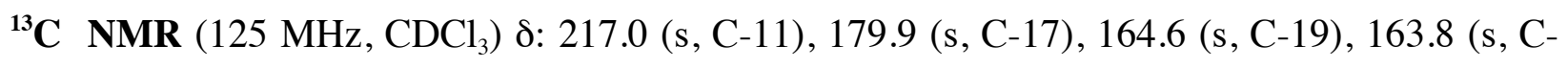
15), 119.2 (s, C-16), 118.2 (s, C-18), 103.2 (s, C-3), 101.4 (s, C-9), 99.6 (s, C-7), 78.4 (d, C-5), 72.4 (d, C-13), 52.0 (d, C-10), 46.4 (d, C-12), 38.7 (d, C-14), 37.4 (d, C-8), 37.0 (d, C-4), 36.6 (d, C-6), 29.6 (t, C-2), 25.0 (t, C-20), 15.9 (q, $\left.\mathrm{CH}_{3} \mathrm{C}-14\right), 13.2$ (q, $\left.\mathrm{CH}_{3} \mathrm{C}-6\right), 12.5$ (q, $\left.\mathrm{CH}_{3} \mathrm{C}-4\right)$, 11.4 (q, C-21), 10.8 (q, $\left.\mathrm{CH}_{3} \mathrm{C}-10\right), 10.1$ (q, $\left.\mathrm{CH}_{3} \mathrm{C}-12\right), 9.9$ (q, $\left.\mathrm{CH}_{3} \mathrm{C}-16\right), 9.8$ (q, $\left.\mathrm{CH}_{3} \mathrm{C}-18\right), 8.3$ $\left(\mathrm{q}, \mathrm{CH}_{3} \mathrm{C}-8\right), 6.4(\mathrm{q}, \mathrm{C}-1), 2.2\left(\mathrm{q} \times 3, \mathrm{CH}_{3} \mathrm{Si}\right)$ 
LRMS (EI), m/z (relative intensity): 592 ([M] $\left.{ }^{+}, 10\right), 467$ (57), 349 (63), 209 (19), 180 (70), 179 (39), 169 (22), 73 (42), 57 (100)

HRMS $m / z$ calcd for $\mathrm{C}_{32} \mathrm{H}_{52} \mathrm{O}_{8} \mathrm{Si}$ : 592.3431; found: 592.3446 (EI).

ent-(13S)-11-Didehydro-13-dihydro-7-O-(trimethylsilyl)caloundrin B (192)

syn-aldol-B

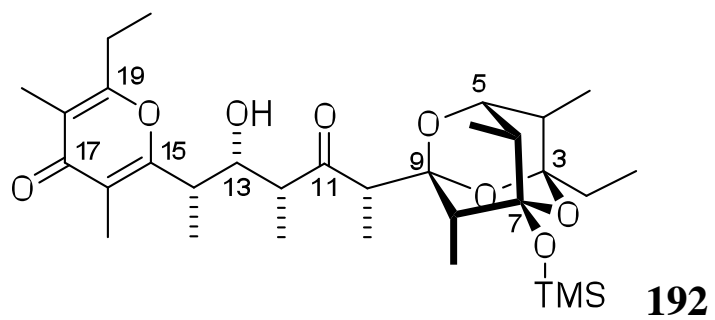

$n$-BuLi (2.4 M in hexanes; $0.012 \mathrm{~mL}, 0.027 \mathrm{mmol}$ ) was added to a stirred solution of tertbutyl(trimethylsilyl)amine $(0.006 \mathrm{~mL}, 4 \mathrm{mg}, 0.03 \mathrm{mmol})$ in $\mathrm{THF}(0.1 \mathrm{~mL})$ at $0{ }^{\circ} \mathrm{C}$ under argon. After $3 \mathrm{~min}$, the reaction mixture was warmed to room temperature and, after $15 \mathrm{~min}$, was cooled $0{ }^{\circ} \mathrm{C}$. A solution of ketone ent-95 $(7 \mathrm{mg}, 0.02 \mathrm{mmol})$ in THF $(0.1 \mathrm{~mL}$ plus $3 \times 0.1 \mathrm{~mL}$ rinses $)$ was added, After $10 \mathrm{~min}$, the mixture cooled to $-78{ }^{\circ} \mathrm{C}$, and a solution of freshly prepared aldehyde ( \pm )-30 $(11.5 \mathrm{mg}, 0.055 \mathrm{mmol})$ in THF $(0.3 \mathrm{~mL})$ was added. After $20 \mathrm{~min}$, the reaction was quenched by addition of phosphate buffer $(\mathrm{pH}=7 ; 1 \mathrm{~mL})$. The mixture was extracted with ethyl acetate. The combined organic layers were dried over $\mathrm{Na}_{2} \mathrm{SO}_{4}$, concentrated, and fractionated by FCC (20\%-100\% ethyl acetate in hexanes) to provide recovered starting ketone ent-95 (2 mg, $28 \%$ ), and a mixture of aldol adducts that were further fractionated by PTLC (30\% ethyl acetate in hexane, multiple elution) to provide a 1.5:1 mixture of two anti aldols $(2.5 \mathrm{mg}$, ca. $23 \%)$, synaldol-A 190 (2 mg,18\%), and syn-aldol-B $192(3 \mathrm{mg}, 28 \%) \cdot[\alpha]_{\mathrm{D}}+15\left(c 0.3, \mathrm{CHCl}_{3}\right)$

IR $v_{\max }: 3396,1716,1653,1595 \mathrm{~cm}^{-1}$ 


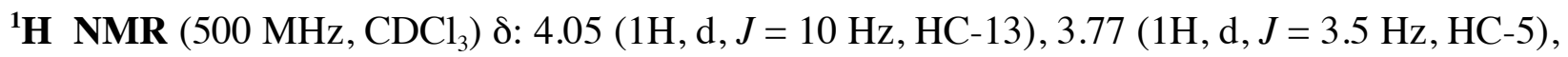
$3.16(1 \mathrm{H}, \mathrm{s}, \mathrm{HO}), 3.03(1 \mathrm{H}, \mathrm{dq}, J=10,7 \mathrm{~Hz}, \mathrm{HC}-14), 2.89(1 \mathrm{H}, \mathrm{q}, J=7 \mathrm{~Hz}, \mathrm{HC}-10), 2.73(1 \mathrm{H}$, $\mathrm{q}, J=7 \mathrm{~Hz}, \mathrm{HC}-12), 2.63(1 \mathrm{H}, \mathrm{dq}, J=15,7.5 \mathrm{~Hz}, \mathrm{HC}-20), 2.54(1 \mathrm{H}, \mathrm{dq}, J=15,7.5 \mathrm{~Hz}, \mathrm{HC}-20)$, $2.13(1 \mathrm{H}, \mathrm{q}, J=6.5 \mathrm{~Hz}, \mathrm{HC}-8), 2.01-1.91(2 \mathrm{H}, \mathrm{m}, \mathrm{HC}-4, \mathrm{HC}-6), 1.98$ (3H, s, $\left.\mathrm{H}_{3} \mathrm{CC}-16\right), 1.95$ $\left(3 \mathrm{H}, \mathrm{s}, \mathrm{H}_{3} \mathrm{CC}-18\right), 1.64-1.50(1 \mathrm{H}, \mathrm{m}, \mathrm{HC}-2), 1.50-1.39(1 \mathrm{H}, \mathrm{m}, \mathrm{HC}-2), 1.34(3 \mathrm{H}, \mathrm{d}, J=7 \mathrm{~Hz}$, $\left.\mathrm{H}_{3} \mathrm{CC}-14\right), 1.20\left(3 \mathrm{H}, \mathrm{t}, J=7.5 \mathrm{~Hz}, \mathrm{H}_{3} \mathrm{C}-21\right), 1.15\left(3 \mathrm{H}, \mathrm{d}, J=7 \mathrm{~Hz}, \mathrm{H}_{3} \mathrm{CC}-10\right), 1.10(3 \mathrm{H}, \mathrm{d}, J=7$ $\left.\mathrm{Hz}, \mathrm{H}_{3} \mathrm{CC}-6\right), 1.07$ (3H, d, $\left.J=7 \mathrm{~Hz}, \mathrm{H}_{3} \mathrm{CC}-12\right), 0.88\left(3 \mathrm{H}, \mathrm{d}, J=7 \mathrm{~Hz}, \mathrm{H}_{3} \mathrm{CC}-4\right), 0.84$ (3H, t, $J=$ $\left.7.5 \mathrm{~Hz}, \mathrm{H}_{3} \mathrm{C}-1\right), 0.81\left(3 \mathrm{H}, \mathrm{d}, J=6.5 \mathrm{~Hz}, \mathrm{H}_{3} \mathrm{CC}-8\right), 0.14\left(9 \mathrm{H}, \mathrm{s}, \mathrm{H}_{3} \mathrm{CSi} \times 3\right)$

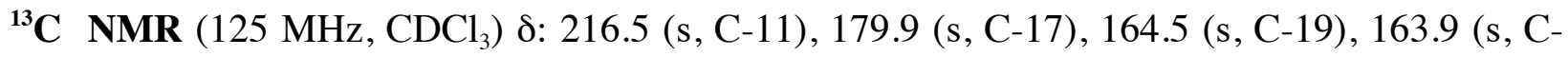
15), 119.2 (s, C-16), 118.3 (s, C-18), 103.1 (s, C-3), 102.0 (s, C-9), 99.7 (s, C-7), 78.6 (d, C-5), 72.4 (d, C-13), 51.3 (d, C-10), 46.1 (d, C-12), 38.9 (d, C-14), 37.4 (d, C-4), 36.7 (d, C-6), 36.0 (d, C-8), 29.6 (t, C-2), 25.0 (t, C-20), 15.9 (q, $\left.\mathrm{CH}_{3} \mathrm{C}-14\right), 13.3$ (q, $\left.\mathrm{CH}_{3} \mathrm{C}-6\right), 12.6$ (q, $\left.\mathrm{CH}_{3} \mathrm{C}-4\right)$, 11.6 (q, C-21), 10.7 (q, $\left.\mathrm{CH}_{3} \mathrm{C}-10\right), 10.0$ (q, $\left.\mathrm{CH}_{3} \mathrm{C}-16\right), 9.9$ (q, $\left.\mathrm{CH}_{3} \mathrm{C}-18\right), 9.7$ (q, $\left.\mathrm{CH}_{3} \mathrm{C}-12\right), 8.1$ $\left(\mathrm{q}, \mathrm{CH}_{3} \mathrm{C}-8\right), 6.3(\mathrm{q}, \mathrm{C}-1), 2.1\left(\mathrm{q} \times 3, \mathrm{CH}_{3} \mathrm{Si}\right)$

LRMS (EI), m/z (relative intensity): 592 ([M] $\left.]^{+}, 11\right), 468$ (24), 467 (73), 349 (76), 209 (25), 180 (97), $179(44), 73(64), 57(100)$

HRMS $\mathrm{m} / \mathrm{z}$, calcd for $\mathrm{C}_{32} \mathrm{H}_{52} \mathrm{O}_{8} \mathrm{Si}$ : 592.3431; found: 592.3451 (EI). 
ent-(13S)-11-Didehydro-13-dihydro-7-O-(trimethylsilyl)caloundrin B (191).

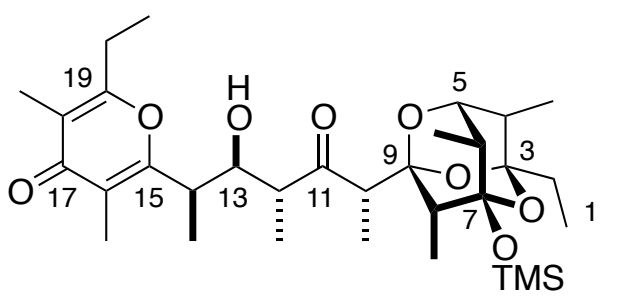

191

$n$-BuLi (2.4 M in hexanes; $0.070 \mathrm{~mL}, 0.17 \mathrm{mmol}$ ) was added to a stirred solution of tertbutyl(trimethylsilyl)amine $(0.035 \mathrm{~mL}, 26 \mathrm{mg}, 0.18 \mathrm{mmol})$ in $\mathrm{THF}(0.7 \mathrm{~mL})$ at $0{ }^{\circ} \mathrm{C}$ under argon. After $1 \mathrm{~min}$, the reaction mixture was warmed to room temperature and, after $15 \mathrm{~min}$, was cooled $0{ }^{\circ} \mathrm{C}$. A solution of ketone ent-95 $(48 \mathrm{mg}, 0.12 \mathrm{mmol})$ in THF $(0.6 \mathrm{~mL}$ plus $3 \times 0.2 \mathrm{~mL}$ rinses $)$ was added, After $10 \mathrm{~min}$, the mixture cooled to $-78^{\circ} \mathrm{C}$, and $\left(c-\mathrm{C}_{6} \mathrm{H}_{12}\right)_{2} \mathrm{BCl}(1 \mathrm{M}$ in hexane; 0.169 $\mathrm{mL}, 0.17 \mathrm{mmol}$ ) was added. After $15 \mathrm{~min}$, a solution of freshly prepared aldehyde $( \pm)-30$ (95 $\mathrm{mg}$, $0.45 \mathrm{mmol})$ in THF $(0.6 \mathrm{~mL})$ was added. After $7 \mathrm{~h}$, the reaction was quenched by sequential addition of phosphate buffer $(\mathrm{pH}=7 ; 1 \mathrm{~mL})$, methanol $(1 \mathrm{~mL})$ and $30 \%$ aq $\mathrm{H}_{2} \mathrm{O}_{2}(1 \mathrm{~mL})$ with vigorous stirring. The mixture was warmed to $0{ }^{\circ} \mathrm{C}$ and, after 10 min, was extracted with $\mathrm{CH}_{2} \mathrm{Cl}_{2}$. The combined organic layers were dried over $\mathrm{Na}_{2} \mathrm{SO}_{4}$, concentrated, and fractionated by FCC (20-50\% ethyl acetate in hexane) to provide the titled compound (38 $\mathrm{mg}, 51 \%)$ and a mixture of diastereomers including 191 (24 mg, 31\%). Fractionation of the latter mixture by PTLC (30\% ethyl acetate in hexane, multiple elution) provided a 2:1 mixture of aldol diastereomers (13 mg, $18 \%)$ and additional titled compound $(7 \mathrm{mg}, 9 \%$; total yield of $\mathbf{1 9 1}=60 \%) \cdot[\alpha]_{\mathrm{D}}+15(c 0.9$, $\left.\mathrm{CHCl}_{3}\right)$

IR $v_{\max }: 3378,1703,1652,1596 \mathrm{~cm}^{-1}$

${ }^{1} \mathbf{H}$ NMR $\left(500 \mathrm{MHz}, \mathrm{CDCl}_{3}\right) \delta: 3.89(1 \mathrm{H}, \mathrm{ddd}, J=6,6.5,7 \mathrm{~Hz}, \mathrm{HC}-13), 3.77(1 \mathrm{H}, \mathrm{br} \mathrm{d}, J=3.5$ Hz, HC-5), 3.11 (1H, dq $J=6,7 \mathrm{~Hz}, \mathrm{HC}-14), 2.93(1 \mathrm{H}, \mathrm{dq}, J=7,7 \mathrm{~Hz}, \mathrm{HC}-12), 2.88(1 \mathrm{H}, \mathrm{q}, J$ 
$=7 \mathrm{~Hz}, \mathrm{HC}-10), 2.70(1 \mathrm{H}, \mathrm{d}, J=6.5 \mathrm{~Hz}, \mathrm{HO}), 2.59\left(2 \mathrm{H}\right.$, ap q, $\left.J=7.5 \mathrm{~Hz}, \mathrm{H}_{2} \mathrm{C}-20\right), 2.09-2.00$ (2H, m, HC-4, HC-8), 1.97-1.91 (1H, m, HC-6), 1.93 (3H, s, $\mathrm{H}_{3} \mathrm{CC}-16$ or $\left.\mathrm{H}_{3} \mathrm{CC}-18\right), 1.92(3 \mathrm{H}, \mathrm{s}$, $\left.\mathrm{H}_{3} \mathrm{CC}-16, \mathrm{H}_{3} \mathrm{CC}-18\right), 1.59(1 \mathrm{H}, \mathrm{dq}, J=14.5,7.5 \mathrm{~Hz}, \mathrm{HC}-2), 1.51(1 \mathrm{H}, \mathrm{dq}, J=14.5,7.5 \mathrm{~Hz}, \mathrm{HC}-$ 2), $1.29\left(3 \mathrm{H}, \mathrm{d}, J=7 \mathrm{~Hz}, \mathrm{H}_{3} \mathrm{CC}-14\right), 1.20\left(3 \mathrm{H}, \mathrm{t}, J=7.5 \mathrm{~Hz}, \mathrm{H}_{3} \mathrm{C}-21\right), 1.19(3 \mathrm{H}, \mathrm{d}, J=7 \mathrm{~Hz}$, $\left.\mathrm{H}_{3} \mathrm{CC}-10\right), 1.12\left(3 \mathrm{H}, \mathrm{d}, J=7 \mathrm{~Hz}, \mathrm{H}_{3} \mathrm{CC}-12\right), 1.03\left(3 \mathrm{H}, \mathrm{d}, J=7 \mathrm{~Hz}, \mathrm{H}_{3} \mathrm{CC}-6\right), 0.92(3 \mathrm{H}, \mathrm{t}, J=7.5$ $\left.\mathrm{Hz}, \mathrm{H}_{3} \mathrm{C}-1\right), 0.92\left(3 \mathrm{H}, \mathrm{d}, J=6.5 \mathrm{~Hz}, \mathrm{H}_{3} \mathrm{CC}-8\right), 0.88\left(3 \mathrm{H}, \mathrm{d}, J=7 \mathrm{~Hz}, \mathrm{H}_{3} \mathrm{CC}-4\right), 0.14(9 \mathrm{H}, \mathrm{s}$, $\left.\mathrm{H}_{3} \mathrm{CSi} \times 3\right)$

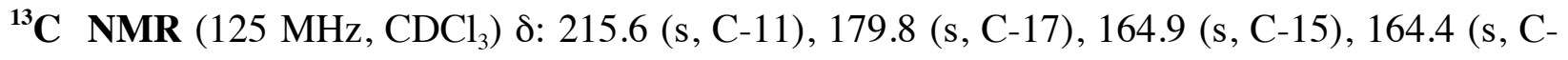
19), 118.6 (s, C-16), 118.3 (s, C-18), 103.1 (s, C-3), 102.2 (s, C-9), 99.8 (s, C-7), 78.5 (d, C-13), 76.6 (d, C-5), 52.1 (d, C-10), 47.5 (d, C-12), 39.0 (d, C-14), 37.2 (d, C-4), 36.9 (d, C-8), 36.8 (d, C-6), 29.6 (t, C-2), 24.9 (t, C-20), 15.1 (q, $\left.\mathrm{CH}_{3} \mathrm{C}-12\right), 13.3$ (q, $\left.\mathrm{CH}_{3} \mathrm{C}-6\right), 13.0$ (q, $\left.\mathrm{CH}_{3} \mathrm{C}-14\right), 12.6$ (q, $\left.\mathrm{CH}_{3} \mathrm{C}-4\right), 11.5$ (q, C-21), 10.5 (q, $\left.\mathrm{CH}_{3} \mathrm{C}-10\right), 9.7$ (q, $\left.\mathrm{CH}_{3} \mathrm{C}-16\right), 9.7$ (q, $\left.\mathrm{CH}_{3} \mathrm{C}-18\right), 8.4$ (q, $\left.\mathrm{CH}_{3} \mathrm{C}-8\right), 6.5(\mathrm{q}, \mathrm{C}-1), 2.2\left(\mathrm{q} \times 3, \mathrm{CH}_{3} \mathrm{Si}\right)$

LRMS (EI), $m / z$ (relative intensity): 592 ([M] $\left.{ }^{+}, 8\right), 523$ (11), 467 (53), 349 (55), 180 (100), 179 (43), $169(22), 73(54), 57$ (56)

HRMS $\mathrm{m} / \mathrm{z}$ calcd for $\mathrm{C}_{32} \mathrm{H}_{52} \mathrm{O}_{8} \mathrm{Si}$ : 592.3431; found: 592.3441 (EI).

ent-(13R)-13-Dihydro-7-O-trimethylsilyl-caloundrin B (194).

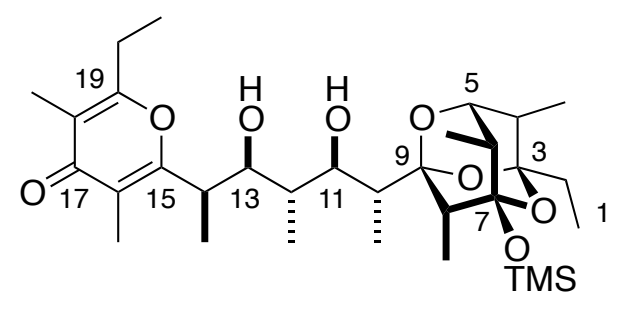

194

$\mathrm{Et}_{2} \mathrm{BOMe}(1 \mathrm{M}$ in toluene; $0.27 \mathrm{~mL}, 0.27 \mathrm{mmol})$ was added to a stirred solution of aldol adduct $191(16 \mathrm{mg}, 0.027 \mathrm{mmol})$ in $\mathrm{THF}(0.23 \mathrm{~mL})$ and $\mathrm{MeOH}(0.077 \mathrm{~mL})$ at $0{ }^{\circ} \mathrm{C}$ under argon. After 
$30 \mathrm{~min}$, the solution was cooled to $-78{ }^{\circ} \mathrm{C}$ and $\mathrm{NaBH}_{4}(44 \mathrm{mg}, 1.1 \mathrm{mmol})$ was added. After 40 min at $-78{ }^{\circ} \mathrm{C}$ and $2.5 \mathrm{~h}$ at $0{ }^{\circ} \mathrm{C}$, phosphate buffer $(\mathrm{pH}=7 ; 0.5 \mathrm{~mL})$ and $\mathrm{MeOH}(0.5 \mathrm{~mL})$ were added to the reaction mixture followed by dropwise addition of $30 \%$ aq $\mathrm{H}_{2} \mathrm{O}_{2}(0.5 \mathrm{~mL})$ (caution: exothermic). After $5 \mathrm{~min}$, the mixture was allowed to warm to ambient temperature. After $2 \mathrm{~h}$, the mixture was extracted $\mathrm{CH}_{2} \mathrm{Cl}_{2}$ and the combined organic layers were dried over $\mathrm{Na}_{2} \mathrm{SO}_{4}$, concentrated, and fractionated by PTLC (30\% ethyl acetate in hexanes) to yield diol 194 (9 mg, $58 \%$ ) and its borate diester (4.6 $\mathrm{mg}, 27 \%)$. The boronate ester, obtained as above from several experiments, was combined $(20 \mathrm{mg})$ and taken up in THF $(2 \mathrm{~mL})$ and $N$-methyldiethanolamine $(0.35 \mathrm{~mL}, 0.38 \mathrm{~g}, 0.87 \mathrm{mmol})$ was added. After $10 \mathrm{~min}$, the mixture was cooled at $0{ }^{\circ} \mathrm{C}$ and phosphate buffer $(\mathrm{pH}=7 ; 2 \mathrm{~mL})$ and $30 \%$ aq $\mathrm{H}_{2} \mathrm{O}_{2}(2 \mathrm{~mL})$ were added sequentially. After $5 \mathrm{~min}$, the mixture was warmed at room temperature and, after $2 \mathrm{~h}$, was extracted with $\mathrm{CH}_{2} \mathrm{Cl}_{2}$. The combined organic layers were dried over $\mathrm{Na}_{2} \mathrm{SO}_{4}$, concentrated, and fractionated by PTLC (50\% ethyl acetate in hexane) to yield diol 194 (17 mg, 91\%). Thus, the overall yield of 194 was 84\%. $[\alpha]_{\mathrm{D}}-3\left(c 0.3, \mathrm{CHCl}_{3}\right)$

IR $v_{\max }: 3413,1652,1592 \mathrm{~cm}^{-1}$

${ }^{1} \mathbf{H}$ NMR (500 MHz, $\left.\mathrm{CDCl}_{3}\right)$ ): 4.42 (1H, br s, HOC-11), 3.98 (1H, br s, HOC-13), 3.80 (1H, d, $J=3.5 \mathrm{~Hz}, \mathrm{HC}-5), 3.78(1 \mathrm{H}, \mathrm{dd}, J=6,6 \mathrm{~Hz}, \mathrm{HC}-13), 3.61(1 \mathrm{H}, \mathrm{dd}, J=5,8 \mathrm{~Hz}, \mathrm{HC}-11), 3.30$ $(1 \mathrm{H}, \mathrm{dddd}, J=7 \mathrm{~Hz}, \mathrm{HC}-14), 2.61\left(2 \mathrm{H}\right.$, ap q, $\left.J=8 \mathrm{~Hz}, \mathrm{H}_{2} \mathrm{C}-20\right), 2.20-2.05(3 \mathrm{H}, \mathrm{m}, \mathrm{HC}-4$, HC-8, HC-10), $1.99(1 \mathrm{H}$, br q, $J=7 \mathrm{~Hz}, \mathrm{HC}-6), 1.97\left(3 \mathrm{H}, \mathrm{s}, \mathrm{H}_{3} \mathrm{CC}-16\right), 1.94\left(3 \mathrm{H}, \mathrm{s}, \mathrm{H}_{3} \mathrm{CC}-18\right), 1.85$ $(1 \mathrm{H}, \mathrm{ddq}, J=6,8,7 \mathrm{~Hz}, \mathrm{HC}-12), 1.63(1 \mathrm{H}, \mathrm{dq}, J=14.5,7.5 \mathrm{~Hz}, \mathrm{HC}-2), 1.53(1 \mathrm{H}, \mathrm{dq}, J=14.5$, $7.5 \mathrm{~Hz}, \mathrm{HC}-2), 1.27\left(3 \mathrm{H}, \mathrm{d}, J=7 \mathrm{~Hz}, \mathrm{H}_{3} \mathrm{CC}-14\right), 1.21\left(3 \mathrm{H}, \mathrm{t}, J=7.5 \mathrm{~Hz}, \mathrm{H}_{3} \mathrm{C}-21\right), 1.04(3 \mathrm{H}, \mathrm{d}, J$ $\left.=7 \mathrm{~Hz}, \mathrm{H}_{3} \mathrm{CC}-10\right), 1.03\left(3 \mathrm{H}, \mathrm{d}, J=7 \mathrm{~Hz}, \mathrm{H}_{3} \mathrm{CC}-6\right), 0.97-0.91\left(6 \mathrm{H}, \mathrm{d}, J=7 \mathrm{~Hz}, \mathrm{H}_{3} \mathrm{CC}-8, \mathrm{H}_{3} \mathrm{CC}-\right.$ 12), $0.93\left(3 \mathrm{H}, \mathrm{t}, J=7.5 \mathrm{~Hz}, \mathrm{H}_{3} \mathrm{C}-1\right), 0.90\left(3 \mathrm{H}, \mathrm{d}, J=7 \mathrm{~Hz}, \mathrm{H}_{3} \mathrm{CC}-4\right), 0.16\left(9 \mathrm{H}, \mathrm{s}, \mathrm{H}_{3} \mathrm{CSi} \times 3\right)$ 
${ }^{13} \mathrm{C}$ NMR (125 MHz, $\mathrm{CDCl}_{3}$ ) \&: 180.1 (s, C-17), 165.9 (s, C-15), 164.5 (s, C-19), 118.3 (s, C16), 118.1 (s, C-18), 104.9 (s, C-9), 102.9 (s, C-3), 99.6 (s, C-7), 81.0 (d, C-11), 79.0 (d, C-5), 78.4 (d, C-13), 41.8 (d, C-10), 40.2 (d, C-14), 39.6 (d, C-12), 37.7 (d, C-8), 37.4 (d, C-4), 36.7 (d, C-6), 29.7 (t, C-2), 25.0 (t, C-20), 16.8 (q, $\left.\mathrm{CH}_{3} \mathrm{C}-12\right), 13.8$ (q, $\left.\mathrm{CH}_{3} \mathrm{C}-10\right), 13.5$ (q, $\left.\mathrm{CH}_{3} \mathrm{C}-6\right)$, 12.8 (q, $\left.\mathrm{CH}_{3} \mathrm{C}-14\right), 12.6$ (q, $\left.\mathrm{CH}_{3} \mathrm{C}-4\right), 11.6$ (q, C-21), 9.8 (q, $\left.\mathrm{CH}_{3} \mathrm{C}-16\right), 9.7$ (q, $\left.\mathrm{CH}_{3} \mathrm{C}-18\right), 8.8$ (q, $\left.\mathrm{CH}_{3} \mathrm{C}-8\right), 6.5(\mathrm{q}, \mathrm{C}-1), 2.2(\mathrm{q} \times 3, \mathrm{CH} 3-\mathrm{Si})$

LRMS (EI), $m / z$ (relative intensity): 594 ([M] $\left.]^{+}, 3\right), 469$ (12), 351 (15), 267 (19), 181 (17), 180 (100), $153(10), 73(21), 57(37)$

HRMS $m / z$ calcd for $\mathrm{C}_{32} \mathrm{H}_{54} \mathrm{O}_{8} \mathrm{Si}$ : 594.3588; found: 594.3597 (EI).

ent-(13S)-13-Dihydro-11-O-triethylsilyl-7-O-trimethylsilyl-caloundrin B (195).

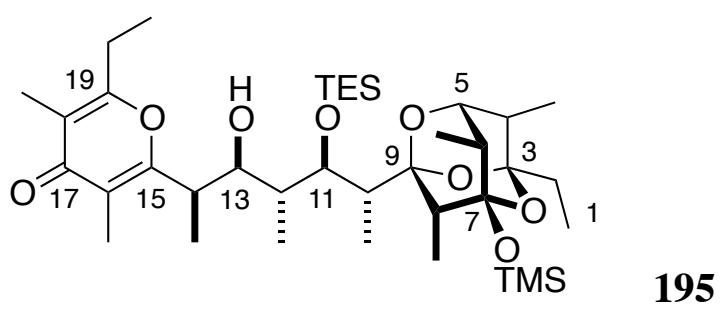

2,6-Lutidine (46 uL,42 mg, $0.392 \mathrm{mmol})$ and TESOTf $(0.01 \mathrm{~mL}, 10 \mathrm{mg}, 0.044 \mathrm{mmol})$ were sequentially added to a solution of diol $194(23 \mathrm{mg}, 0.039 \mathrm{mmol})$ in $\mathrm{CH}_{2} \mathrm{Cl}_{2}(3.9 \mathrm{~mL})$ at $-50{ }^{\circ} \mathrm{C}$ under argon. After $6 \mathrm{~min}$, the reaction mixture was diluted with ethyl acetate and washed sequentially with $1 \%$ aq citric acid, saturated aq $\mathrm{NaHCO}_{3}$, and brine. The organic layer was dried over $\mathrm{Na}_{2} \mathrm{SO}_{4}$, concentrated, and fractionated by PTLC (30\% ethyl acetate in hexanes) to yield recovered diol $194(14 \mathrm{mg}, 61 \%)$ and the titled compound as a colorless oil (9 $\mathrm{mg}, 31 \%$; $79 \%$ BORSM $) \cdot[\alpha]_{\mathrm{D}}+10\left(c 0.35, \mathrm{CHCl}_{3}\right)$

IR $v_{\max }: 3437,1653,1611,1596 \mathrm{~cm}^{-1}$ 


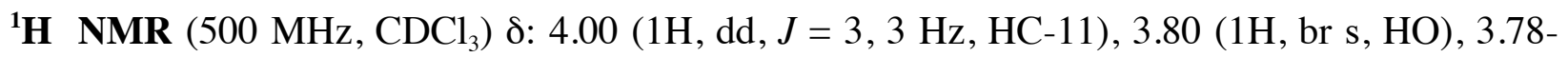
$3.71(2 \mathrm{H}, \mathrm{m}, \mathrm{HC}-5, \mathrm{HC}-13), 3.11(1 \mathrm{H}, \mathrm{dq}, J=4,7 \mathrm{~Hz}, \mathrm{HC}-14), 2.62\left(2 \mathrm{H}\right.$, ap q, $J=7.5 \mathrm{~Hz}, \mathrm{H}_{2} \mathrm{C}-$ 20), 2.37-2.25 (1H, m, HC-12), 2.05 (1H, dq, $J=4,7$ Hz, HC-4), 2.02-1.90 (2H, m, HC-6, HC10), 1.97 (3H, s, $\left.\mathrm{H}_{3} \mathrm{CC}-16\right), 1.95$ (3H, s, $\left.\mathrm{H}_{3} \mathrm{CC}-18\right), 1.85$ (1H, q, J = 6.5 Hz, HC-8), 1.70-1.46 $\left(2 \mathrm{H}, \mathrm{m}, \mathrm{H}_{2} \mathrm{C}-2\right), 1.24\left(3 \mathrm{H}, \mathrm{d}, J=7 \mathrm{~Hz}, \mathrm{H}_{3} \mathrm{CC}-14\right), 1.21\left(3 \mathrm{H}, \mathrm{t}, J=7.5 \mathrm{~Hz}, \mathrm{H}_{3} \mathrm{C}-21\right), 1.09$ (3H, d, $\left.J=7 \mathrm{~Hz}, \mathrm{H}_{3} \mathrm{CC}-10\right), 1.03\left(3 \mathrm{H}, \mathrm{d}, J=7 \mathrm{~Hz}, \mathrm{H}_{3} \mathrm{CC}-6\right), 0.98\left(3 \mathrm{H}, \mathrm{d}, \mathrm{H}_{3} \mathrm{CC}-8\right), 0.97(3 \mathrm{H}, \mathrm{d}, J=7$ $\left.\mathrm{Hz}, \mathrm{H}_{3} \mathrm{CC}-12\right), 0.94\left(9 \mathrm{H}, \mathrm{t}, J=8 \mathrm{~Hz}, \mathrm{H}_{3} \mathrm{CCSi} \times 3\right), 0.93\left(3 \mathrm{H}, \mathrm{t}, \mathrm{H}_{3} \mathrm{C}-1\right), 0.89\left(3 \mathrm{H}, \mathrm{d}, \mathrm{H}_{3} \mathrm{CC}-4\right)$, $0.61\left(6 \mathrm{H}\right.$, ap q, $\left.\mathrm{H}_{2} \mathrm{CSi} \times 3\right), 0.17\left(9 \mathrm{H}, \mathrm{s}, \mathrm{H}_{3} \mathrm{CSi} \times 3\right)$

${ }^{13} \mathrm{C}$ NMR (125 MHz, $\mathrm{CDCl}_{3}$ ) $\delta: 180.3$ (s, C-17), 166.5 (s, C-15), 164.6 (s, C-19), 117.9 (s, C16), 117.7 (s, C-18), 102.7 (s, C-3), 102.6 (s, C-9), 99.7 (s, C-7), 78.4 (d, C-5), 77.7 (d, C-11), 75.6 (d, C-13), 46.6 (d, C-10), 39.0 (d, C-14), 37.5 (d, C-8), 37.3 (d, C-12), 37.0 (d, C-4), 36.8 (d, C-6), 29.7 (t, C-2), 25.1 (t, C-20), 19.2 (q, $\left.\mathrm{CH}_{3} \mathrm{C}-12\right), 13.4$ (q, $\left.\mathrm{CH}_{3} \mathrm{C}-6\right), 12.6$ (q, $\left.\mathrm{CH}_{3} \mathrm{C}-4\right)$, 11.5 (q, C-21), 10.6 (q, $\left.\mathrm{CH}_{3} \mathrm{C}-14\right), 9.8$ (q, $\left.\mathrm{CH}_{3} \mathrm{C}-16\right), 9.7$ (q, $\left.\mathrm{CH}_{3} \mathrm{C}-18\right), 8.6$ (q, $\left.\mathrm{CH}_{3} \mathrm{C}-8\right), 7.8$ (q, $\left.\mathrm{CH}_{3} \mathrm{C}-10\right), 7.0\left(\mathrm{q} \times 3, \mathrm{CH}_{3} \mathrm{CSi}\right), 6.5(\mathrm{q}, \mathrm{C}-1), 5.2\left(\mathrm{t} \times 3, \mathrm{CH}_{2} \mathrm{Si}\right), 2.2\left(\mathrm{q} \times 3, \mathrm{CH}_{3} \mathrm{Si}\right)$

LRMS (EI), m/z (relative intensity): 708 ([M] $\left.]^{+}, 3\right), 381$ (12), 255 (17), 209 (37), 181 (15), 180 (100), $115(15), 73(20), 57(22)$

HRMS $\mathrm{m} / z$, calcd for $\mathrm{C}_{38} \mathrm{H}_{68} \mathrm{O}_{8} \mathrm{Si}_{2}:$ 708.4453; found: 708.4452 (EI). 
ent-11-O-Triethylsilyl-7- $O$-trimethylsilyl-caloundrin B (196).

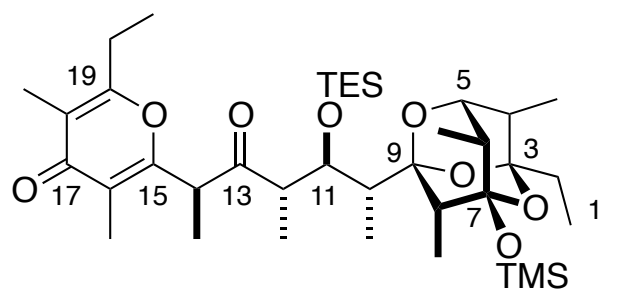

196

IBX (41 mg, $0.1467 \mathrm{mmol})$ was added to a stirred solution of alcohol 195 (13 mg, $0.0183 \mathrm{mmol})$ in DMSO (2.4 mL) at room temperature under Ar. After $13 \mathrm{~h}$, the reaction was diluted with ethyl acetate and washed sequentially with saturated aq $\mathrm{NaHCO}_{3}$, distilled water and brine, dried over $\mathrm{Na}_{2} \mathrm{SO}_{4}$, concentrated, and fractionated by PTLC (30\% ethyl acetate in hexane) to provide the titled compound $(13 \mathrm{mg}, 99 \%) .[\alpha]_{\mathrm{D}}+80\left(c 0.3, \mathrm{CHCl}_{3}\right)$

IR $v_{\max }: 1727,1657,1621 \mathrm{~cm}^{-1}$

${ }^{1} \mathbf{H}$ NMR (500 MHz, $\left.\mathrm{CDCl}_{3}\right) \delta: 4.10(1 \mathrm{H}, \mathrm{dd}, J=2.5,7 \mathrm{~Hz}, \mathrm{HC}-11), 4.08(1 \mathrm{H}, \mathrm{q}, J=7 \mathrm{~Hz}, \mathrm{HC}-$ 14), $3.74(1 \mathrm{H}, \mathrm{d}, J=3.5 \mathrm{~Hz}, \mathrm{HC}-5), 2.93(1 \mathrm{H}, \mathrm{dq}, J=7,7 \mathrm{~Hz}, \mathrm{HC}-12), 2.49-2.57$ (2H, m, $\mathrm{H}_{2} \mathrm{C}-$ 20), 2.08 (3H, s, $\mathrm{H}_{3} \mathrm{CC}-16$ ), 2.02-1.91 (3H, m, HC-4, HC-6, HC-10), 1.95 (3H, s, $\left.\mathrm{H}_{3} \mathrm{CC}-18\right)$, $1.86(1 \mathrm{H}, \mathrm{q}, J=6.5 \mathrm{~Hz}, \mathrm{HC}-8), 1.64-1.43\left(2 \mathrm{H}, \mathrm{m}, \mathrm{H}_{2} \mathrm{C}-2\right), 1.30\left(3 \mathrm{H}, \mathrm{d}, J=7 \mathrm{~Hz}, \mathrm{H}_{3} \mathrm{CC}-14\right), 1.14$ $(3 \mathrm{H}, \mathrm{t}, J=7.5 \mathrm{~Hz}, \mathrm{HC}-21), 1.01\left(24 \mathrm{H}, \mathrm{d}, J=7 \mathrm{~Hz}, \mathrm{H}_{3} \mathrm{CC}-6\right), 0.99\left(3 \mathrm{H}, \mathrm{d}, J=6.5 \mathrm{~Hz}, \mathrm{H}_{3} \mathrm{CC}-10\right)$, $0.97\left(3 \mathrm{H}, \mathrm{d}, J=6.5 \mathrm{~Hz}, \mathrm{H}_{3} \mathrm{CC}-8\right), 0.96\left(3 \mathrm{H}, \mathrm{d}, J=6.5 \mathrm{~Hz}, \mathrm{H}_{3} \mathrm{CC}-12\right), 0.94(9 \mathrm{H}, \mathrm{t}, J=8 \mathrm{~Hz}$, $\left.\mathrm{H}_{3} \mathrm{CCSi} \times 3\right), 0.91\left(3 \mathrm{H}, \mathrm{t}, J=7.5 \mathrm{~Hz}, \mathrm{H}_{3} \mathrm{CC}-1\right), 0.87\left(3 \mathrm{H}, \mathrm{d}, J=7 \mathrm{~Hz}, \mathrm{H}_{3} \mathrm{CC}-4\right), 0.577,3.5(6 \mathrm{H}$, ap $\left.\mathrm{q}, J=8 \mathrm{~Hz}, \mathrm{H}_{2} \mathrm{CSi} \times 3\right), 0.16\left(9 \mathrm{H}, \mathrm{s}, \mathrm{H}_{3} \mathrm{CSi} \times 3\right)$

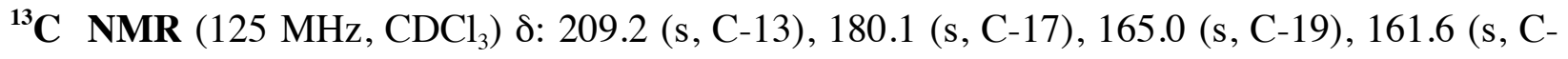
15), 120.3 (s, C-16), 118.4 (s, C-18), 102.7 (s, C-3), 102.0 (s, C-9), 99.8 (s, C-7), 78.6 (d, C-5), 75.0 (d, C-11), 50.9 (d, C-14), 47.5 (d, C-10), 46.2 (d, C-12), 38.0 (d, C-8), 37.1 (d, C-4 ), 36.7 (d, C-6), 29.7 (t, C-2), 24.9 (t, C-20), 15.1 (q, $\left.\mathrm{CH}_{3} \mathrm{C}-12\right), 13.5$ (q, $\left.\mathrm{CH}_{3} \mathrm{C}-6\right), 13.2$ (q, $\left.\mathrm{CH}_{3} \mathrm{C}-14\right)$, 
12.7 (q, $\left.\mathrm{CH}_{3} \mathrm{C}-4\right), 11.5$ (q, C-21), 10.3 (q, $\left.\mathrm{CH}_{3} \mathrm{C}-16\right), 9.7$ (q, $\left.\mathrm{CH}_{3} \mathrm{C}-18\right), 8.6$ (q, $\left.\mathrm{CH}_{3} \mathrm{C}-10\right), 7.5$ (q, $\left.\mathrm{CH}_{3} \mathrm{C}-8\right), 7.1\left(\mathrm{q} \times 3, \mathrm{CH}_{3} \mathrm{Si}\right), 6.4(\mathrm{q}, \mathrm{C}-1), 5.4\left(\mathrm{t} \times 3, \mathrm{CH}_{2} \mathrm{Si}\right), 2.2\left(\mathrm{q} \times 3, \mathrm{CH}_{3} \mathrm{Si}\right)$

LRMS (EI), $m / z$ (relative intensity): 706 ([M] $\left.]^{+}, 8\right), 678$ (18), 677 (37), 581 (56), 527 (30), 379 (43), 349 (100), 255 (49), 180 (46)

HRMS $m / z$ calcd for $\mathrm{C}_{38} \mathrm{H}_{66} \mathrm{O}_{8} \mathrm{Si}: 706.4296$; found: 706.4270 (EI).

ent-Caloundrin B (ent-3).

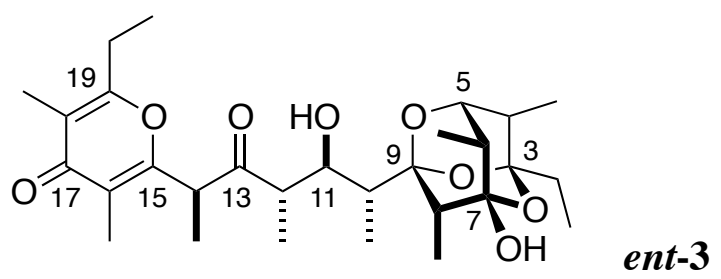

Pyridine $(0.16 \mathrm{~mL}, 16 \mathrm{mg}, 2.0 \mathrm{mmol})$, distilled water $(0.007 \mathrm{~mL}, 7 \mathrm{mg}, 0.4 \mathrm{mmol})$, and HF.pyridine $(0.108 \mathrm{~mL})$ were sequentially added to a stirred solution of ketone 196 in THF (2 $\mathrm{mL}$ ) at room temperature. After $2 \mathrm{~h}$, the mixture was diluted with ethyl acetate and washed sequentially with $1 \%$ aq citric acid $(\times 3)$, saturated aq $\mathrm{NaHCO}_{3}$ and brine. The organic layer was dried over $\mathrm{Na}_{2} \mathrm{SO}_{4}$, concentrated, and fractionated by PTLC (50\% ethyl acetate in hexanes) to give ent-caloundrin B (ent-3) $\left(7 \mathrm{mg}\right.$, quantitative). $[\alpha]_{\mathrm{D}}+50\left(c 0.2, \mathrm{CHCl}_{3}\right)$

IR $v_{\text {max }}: 3385,1653,1598 \mathrm{~cm}^{-1}$

${ }^{1} \mathbf{H}$ NMR $\left(500 \mathrm{MHz}, \mathrm{CDCl}_{3}\right) \delta: 4.14(1 \mathrm{H}, \mathrm{q}, J=7 \mathrm{~Hz}, \mathrm{HC}-14), 3.95(1 \mathrm{H}, \mathrm{d}, J=7.5 \mathrm{~Hz}, \mathrm{HOC}-$ 11), $3.83(1 \mathrm{H}$, br d, $J=3.5 \mathrm{~Hz}, \mathrm{HC}-5), 3.68(1 \mathrm{H}, \mathrm{ddd}, J=5,5,7.5 \mathrm{~Hz}, \mathrm{HC}-11), 3.03(1 \mathrm{H}, \mathrm{dq}, J=$ 5, $7 \mathrm{~Hz}, \mathrm{HC}-12), 2.62\left(1 \mathrm{H}\right.$, br s, HOC-7), 2.62-2.52 (2H, m, $\left.\mathrm{H}_{2} \mathrm{C}-20\right), 2.24(1 \mathrm{H}, \mathrm{q}, J=6.5 \mathrm{~Hz}$, HC-8), $2.10(1 \mathrm{H}, \mathrm{dq}, J=3.5,7 \mathrm{~Hz}, \mathrm{HC}-4), 2.09-2.03$ (2H, m, HC-6, HC-10), 2.07 (3H, s, $\mathrm{H}_{3} \mathrm{CC}-$ 16), $1.95\left(3 \mathrm{H}, \mathrm{s}, \mathrm{H}_{3} \mathrm{CC}-18\right), 1.65-1.54\left(2 \mathrm{H}, \mathrm{m}, \mathrm{H}_{2} \mathrm{C}-2\right), 1.38\left(3 \mathrm{H}, \mathrm{d}, J=7 \mathrm{~Hz}, \mathrm{H}_{3} \mathrm{CC}-14\right), 1.16$ 
$\left(3 \mathrm{H}, \mathrm{t}, J=7.5 \mathrm{~Hz}, \mathrm{H}_{3} \mathrm{C}-21\right), 1.09\left(3 \mathrm{H}, \mathrm{d}, J=7 \mathrm{~Hz}, \mathrm{H}_{3} \mathrm{CC}-6\right), 1.03\left(3 \mathrm{H}, \mathrm{d}, J=7 \mathrm{~Hz}, \mathrm{H}_{3} \mathrm{CC}-12\right)$, $0.99\left(3 \mathrm{H}, \mathrm{d}, J=6.5 \mathrm{~Hz}, \mathrm{H}_{3} \mathrm{CC}-8\right), 0.97\left(3 \mathrm{H}, \mathrm{d}, J=7 \mathrm{~Hz}, \mathrm{H}_{3} \mathrm{CC}-10\right), 0.93\left(3 \mathrm{H}, \mathrm{t}, J=7.5 \mathrm{~Hz}, \mathrm{H}_{3} \mathrm{C}-\right.$ 1), $0.93\left(3 \mathrm{H}, \mathrm{d}, J=7 \mathrm{~Hz}, \mathrm{H}_{3} \mathrm{CC}-4\right)$

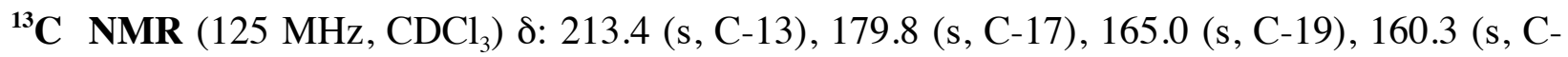
15), 120.4 (s, C-16), 118.7 (s, C-18), 103.1 (s, C-9), 103.0 (s, C-3), 97.4 (s, C-7), 78.6 (d, C-5), 77.7 (d, C-11), 50.7 (d, C-14), 46.5 (d, C-12), 42.0 (d, C-10), 36.9 (d, C-8), 36.8 (d, C-4), 35.8 (d, C-6), 29.7 (t, C-2), 24.9 (t, C-20), 16.3 (q, $\left.\mathrm{CH}_{3} \mathrm{C}-12\right), 13.6\left(\mathrm{q} \times 2, \mathrm{CH}_{3} \mathrm{C}-6\right.$ anCH $\left.\mathrm{H}_{3} \mathrm{C}-14\right), 12.6$ (q, $\left.\mathrm{CH}_{3} \mathrm{C}-4\right), 11.5$ (q, C-21), 11.4 (q, $\left.\mathrm{CH}_{3} \mathrm{C}-10\right), 10.4$ (q, $\left.\mathrm{CH}_{3} \mathrm{C}-16\right), 9.8$ (q, $\left.\mathrm{CH}_{3} \mathrm{C}-18\right), 7.7$ (q, $\left.\mathrm{CH}_{3} \mathrm{C}-8\right), 6.5$ (q, C-1)

LRMS (EI), m/z (relative intensity): 520 ([M] $\left.]^{+}, 1\right), 236$ (9), 207 (3), 181 (13), 180 (100), 179 (16), $153(12), 125(8), 69(7), 57(42)$

HRMS $\mathrm{m} / \mathrm{z}$ calcd for $\mathrm{C}_{29} \mathrm{H}_{44} \mathrm{O}_{8}: 520.3036$; found: 520.3027 (EI). 


\section{REFERENCES}

1. Davies-Coleman, M. T.; Garson, M. J., Marine polypropionates. Nat. Prod. Rep. 1998, 15 (5), 477-493.

2. Avila, C., Molluscan natural products as biological models: chemical ecology, histology, and laboratory culture. Prog. Mol. Subcell. Biol. 2006, 43 (Molluscs), 1-23.

3. Darias, J.; Cueto, J.; Diaz-Marrero, A. R., The chemistry of marine pulmonate gastropods. Prog. Mol. Subcell. Biol. 2006, 43 (Molluscs), 105-131.

4. Garson, M. J., Marine mollusks from Australia and New Zealand: chemical and ecological studies. Prog. Mol. Subcell. Biol. 2006, 43 (Molluscs), 159-174.

5. Hochlowski, J.; Coll, J.; Faulkner, D. J.; Clardy, J., Novel metabolites of four Siphonaria species. J. Am. Chem. Soc. 1984, 106 (22), 6748-6750.

6. Garson, M. J.; Jones, D. D.; Small, C. J.; Liang, J.; Clardy, J., Biosynthetic studies on polypropionates: a stereochemical model for siphonarins A and B from the pulmonate limpet Siphonaria zelandica. Tetrahedron Lett. 1994, 35 (37), 6921-6924.

7. Paterson, I.; Franklin, A. S., Assignment of the absolute configuration of the siphonarins and baconipyrones. Enantiocontrolled synthesis of a $\gamma$-pyrone subunit. Tetrahedron Lett. 1994, 35 (37), 6925-6928.

8. Paterson, I.; Chen, D. Y.-K.; Franklin, A. S., Total synthesis of siphonarin B and dihydrosiphonarin B. Org. Lett. 2002, 4 (3), 391-394.

9. Beye, G. E.; Ward, D. E., On the origin of siphonariid polypropionates: Total synthesis of baconipyrone $\mathrm{A}$, baconipyrone $\mathrm{C}$, and siphonarin $\mathrm{B}$ via their putative common precursor. $J$. Am. Chem. Soc. 2010, 132 (20), 7210-7215. 
10. Manker, D. C.; Faulkner, D. J.; Stout, T. J.; Clardy, J., The baconipyrones. Novel polypropionates from the pulmonate Siphonaria baconi. J. Org. Chem. 1989, 54 (22), $5371-5374$.

11. Brecknell, D. J.; Collett, L. A.; Davies-Coleman, M. T.; Garson, M. J.; Jones, D. D., New non-contiguous polypropionates from marine molluscs: A comment on their natural product status. Tetrahedron 2000, $56(16), 2497-2502$.

12. Paterson, I.; Chen, D. Y.-K.; Acena, J. L.; Franklin, A. S., Studies in marine polypropionate synthesis: Total synthesis of (-)-baconipyrone C. Org. Lett. 2000, 2 (11), $1513-1516$.

13. Gillingham, D. G.; Hoveyda, A. H., Chiral N-heterocyclic carbenes in natural product synthesis: Application of Ru-catalyzed asymmetric ring-opening/cross-metathesis and $\mathrm{Cu}$ catalyzed allylic alkylation to total synthesis of baconipyrone C. Angew. Chem., Int. Ed. 2007, 46 (21), 3860-3864.

14. Yadav, J. S.; Sathaiah, K.; Srinivas, R., Total synthesis of (-)-baconipyrone C. Tetrahedron 2009, 65 (17), 3545-3552.

15. Blanchfield, J. T.; Brecknell, D. J.; Brereton, I. M.; Garson, M. J.; Jones, D. D., Caloundrin B and funiculatin A: new polypropionates from siphonariid limpets. Aust. J. Chem. 1994, 47 (12), 2255-2269.

16. Manker, D. C.; Garson, M. J.; Faulkner, D. J., De Novo biosynthesis of polypropionate metabolites in the marine pulmonate Siphonaria denticulata. J. Chem. Soc., Chem. Commun. 1988, (16), 1061-1062.

17. Celmer, W. D., Macrolide stereochemistry. III. A configurational model for macrolide antibiotics1. J. Am. Chem. Soc. 1965, 87 (8), 1801-1802. 
18. Cane, D. E.; Celmer, W. D.; Westley, J. W., Unified stereochemical model of polyether antibiotic structure and biogenesis. J. Am. Chem. Soc. 1983, 105 (11), 3594-3600.

19. Garson, M. J.; Goodman, J. M.; Paterson, I., A configuration model for siphonariid polypropionates derived from structural and biosynthetic considerations. Tetrahedron Lett. 1994, 35 (37), 6929-6932.

20. T. Davies-Coleman, M.; J. Garson, M., Marine polypropionates. Nat. Prod. Rep. 1998, 15 (5), 477-493.

21. Paterson, I.; Norcross, R. D.; Ward, R. A.; Romea, P.; Lister, M. A., Studies in macrolide synthesis: A stereocontrolled synthesis of oleandolide employing reagent- and substratecontrolled aldol reactions of (S)-1-(benzyloxy)-2-methylpentan-3-one. J. Am. Chem. Soc. 1994, $116(25), 11287-11314$.

22. Paterson, I.; Perkins, M. V., Total synthesis of (-)-denticulatins A and B using efficient methods of acyclic stereocontrol. Tetrahedron 1996, 52 (5), 1811-1834.

23. Evans, D. A.; Hoveyda, A. H., Samarium-catalyzed intramolecular Tishchenko reduction of .beta.-hydroxy ketones. A stereoselective approach to the synthesis of differentiated anti 1,3-diol monoesters. J. Am. Chem. Soc. 1990, 112 (17), 6447-6449.

24. Jin, H.; Uenishi, J.; Christ, W. J.; Kishi, Y., Catalytic effect of nickel(II) chloride and palladium(II) acetate on chromium(II)-mediated coupling reaction of iodo olefins with aldehydes. J. Am. Chem. Soc. 1986, 108 (18), 5644-5646.

25. Takai, K.; Tagashira, M.; Kuroda, T.; Oshima, K.; Utimoto, K.; Nozaki, H., Reactions of alkenylchromium reagents prepared from alkenyl trifluoromethanesulfonates (triflates) with chromium(II) chloride under nickel catalysis. J. Am. Chem. Soc. 1986, 108 (19), 6048-6050. 
26. Arimoto, H.; Nishiyama, S.; Yamamum, S., Mild conditions for cyclization of $\beta$-triketides to the corresponding $\gamma$-pyrones carrying adjacent chiral centers toward biomimetic synthesis of fully substituted $\gamma$-pyrone-containing natural products. Tetrahedron Lett. 1990, $31(39), 5619-5620$.

27. Pratt, N. E.; Zhao, Y.-b.; Hitchcock, S.; Albizati, K. F., Generation of polypropionate fragments via a tandem aldol-bis-oxidation procedure. Synlett 1991, 1991 (5), 361-363.

28. Arimoto, H.; Ohba, S.; Nishiyama, S.; Yamamura, S., Chemical properties of $\beta$-triketones: Reexamination of Albizati's tandem aldol process. Tetrahedron Lett. 1994, 35 (26), 45814584.

29. Ward, D. E., The thiopyran route to polypropionates. Chem. Commun. 2011, 47 (41), 11375-11393.

30. Bettelli, E.; Cherubini, P.; D'Andrea, P.; Passacantilli, P.; Piancatelli, G., Mercurationreductive demercuration of glycals: A mild and convenient entry to 2-deoxy-sugars. Tetrahedron 1998, 54 (22), 6011-6018.

31. Passacantilli, P.; Centore, C.; Ciliberti, E.; Leonelli, F.; Piancatelli, G., A highly efficient and stereocontrolled synthesis of 2-deoxy-1,5-thioanhydro-L-hexitols from D-glycals in a tandem nucleophilic displacement reaction. Eur. J. Org. Chem. 2006, (14), 3097-3104.

32. Roll, D. M.; Biskupiak, J. E.; Mayne, C. L.; Ireland, C. M., Muamvatin, a novel tricyclic spiro ketal from the Fijian mollusk Siphonaria normalis. J. Am. Chem. Soc. 1986, 108 (21), $6680-6682$.

33. Hoffmann, R. W.; Dahmann, G., Synthesis of a hydroxytrioxaadamantane, a model for the trioxaadamantane moiety of muamvatin. Chem. Ber. 1994, 127 (7), 1317-1322. 
34. Hoffman, R. W.; Dahmann, G., The absolute and relative configuration of muamvatin. Tetrahedron Lett. 1993, 34 (7), 1115-1118.

35. Dahmann, G.; Hoffmann, R. W., The absolute configuration of muamvatin. Liebigs Ann. Chem. 1994, (8), 837-845.

36. Paterson, I.; Perkins, M. V., Total synthesis of the marine polypropionate (+)-muamvatin. A configurational model for siphonariid metabolites. J. Am. Chem. Soc. 1993, 115 (4), 1608-1610.

37. Lister, T.; Perkins, M. V., A retro-Claisen approach to dolabriferol. Org. Lett. 2006, 8 (9), 1827-1830.

38. Scheidt, K. A.; Chen, H.; Follows, B. C.; Chemler, S. R.; Coffey, D. S.; Roush, W. R., Tris(dimethylamino)sulfonium difluorotrimethylsilicate, a mild reagent for the removal of silicon protecting groups. J. Org. Chem. 1998, 63 (19), 6436-6437.

39. Beye, G. E.; Goodman, J. M.; Ward, D. E., Synthetic studies on siphonariid polypropionates: Synthesis and isomerization of the caloundrin B trioxaadamantane ring system. Org. Lett. 2009, 11 (6), 1373-1376.

40. Ward, D. E.; Jheengut, V.; Beye, G. E.; Gillis, H. M.; Karagiannis, A.; Becerril-Jimenez, F., Enantioselective direct aldol reactions of achiral ketones with racemic enolizable $\alpha$ substituted aldehydes: scope and limitations. Synlett 2011, (EFirst), 508,512.

41. Arimoto, H.; Yokoyama, R.; Okumura, Y., Synthesis and revised structure of vallartanone B. Tetrahedron Lett. 1996, 37 (27), 4749-4750.

42. Sengoku, T.; Takemura, T.; Fukasawa, E.; Hayakawa, I.; Kigoshi, H., Aldol-type reaction of a 4-pyrone: a straightforward approach to 4-pyrone-containing natural products. Tetrahedron Lett. 2009, 50 (3), 325-328. 


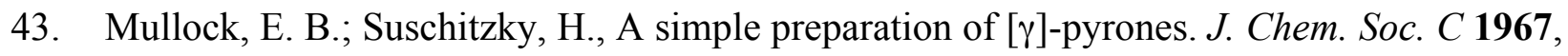
828-830.

44. Ward, D. E.; Rasheed, M. A.; Gillis, H. M.; Beye, G. E.; Jheengut, V.; Achonduh, G. T., Simple and efficient preparation of reagents for thiopyran introduction. Methyl tetrahydro4-oxo- $2 H$-thiopyran-3-carboxylate, tetrahydro-4H-thiopyran-4-one, and 3,6-dihydro-4trimethylsilyloxy-2H-thiopyran. Synthesis 2007, (10), 1584-1586.

45. Ward, D. E.; Beye, G. E.; Sales, M.; Alarcon, I. Q.; Gillis, H. M.; Jheengut, V., Thiopyran route to polypropionates: Exploiting and overcoming double stereodifferentiation and mutual kinetic enantioselection in aldol couplings of chiral fragments. J. Org. Chem. 2007, $72(5), 1667-1674$.

46. Ward, D. E.; Becerril-Jimenez, F.; Zahedi, M. M., Rational design of aldol reactions that proceed via kinetic resolution with switchable enantioselectivity. J. Org. Chem. 2009, 74 (12), 4447-4454.

47. Hayakawa, R.; Shimizu, M., Synthesis of chiral epoxides from aldehydes using sulfur ylide derived from reduced product of bakers' yeast reduction. Synlett 1999, (8), 1328-1330.

48. Heathcock, C. H.; Ratcliffe, R., Stereoselective total synthesis of the guaiazulenic sesquiterpenoids $\alpha$-bulnesene and bulnesol. J. Am. Chem. Soc. 1971, 93 (7), 1746-1757.

49. Sharpless, K. B.; Young, M. W., Olefin synthesis. Rate enhancement of the elimination of alkyl aryl selenoxides by electron-withdrawing substituents. J. Org. Chem. 1975, 40 (7), 947-949.

50. Grieco, P. A.; Gilman, S.; Nishizawa, M., Organoselenium chemistry. A facile one-step synthesis of alkyl aryl selenides from alcohols. J. Org. Chem. 1976, 41 (8), 1485-1486. 
51. Frigerio, M.; Santagostino, M.; Sputore, S.; Palmisano, G., Oxidation of alcohols with oiodoxybenzoic acid in DMSO: A new insight into an old hypervalent iodine reagent. $J$. Org. Chem. 1995, 60 (22), 7272-7276.

52. Ward, D. E.; Sales, M.; Sasmal, P. K., Syn-anti isomerization of aldols by enolization. $J$. Org. Chem. 2004, 69 (14), 4808-4815.

53. Ward, D. E.; Jheengut, V.; Akinnusi, O. T., Enantioselective direct intermolecular aldol reactions with enantiotopic group selectivity and dynamic kinetic resolution. Org. Lett. 2005, 7 (6), 1181-1184.

54. Masamune, S.; Choy, W.; Petersen, J. S.; Sita, L. R., Double asymmetric synthesis and a new strategy for stereochemical control in organic synthesis. Angew. Chem. Int. Ed. 1985, $24(1), 1-30$.

55. Nakayama, K., A derivation of the Masamune rule of multiplicativity in double asymmetric induction. J. Chem. Educ. 1990, 67 (1), 20.

56. Heathcock, C. H.; Pirrung, M. C.; Lampe, J.; Buse, C. T.; Young, S. D., Acyclic stereoselection. 12. Double stereodifferentiation with mutual kinetic resolution. A superior class of reagents for control of Cram's rule stereoselection in synthesis of erythro- $\alpha$-alkyl$\beta$-hydroxy carboxylic acids from chiral aldehydes. J. Org. Chem. 1981, 46 (11), 22902300.

57. Horeau, A., Method for obtaining enantiomer containing less than $0.1 \%$ of its antipode. Determination of its maximum rotatory power. Tetrahedron 1975, 31 (10), 1307-9.

58. Nebot, J.; Romea, P.; Urpí, F., Stereoselective synthesis of highly functionalized structures from lactate-derived halo ketones. J. Org. Chem. 2009, 74 (19), 7518-7521. 
59. Girard, C.; Kagan, H. B., Nonlinear effects in asymmetric synthesis and stereoselective reactions: Ten years of investigation. Angew. Chem., Int. Ed. 1998, 37 (21), 2922-2959.

60. Kagan, H. B., Nonlinear effects in asymmetric catalysis: A personal account. Synlett 2001, 888-899.

61. Satyanarayana, T.; Abraham, S.; Kagan, H. B., Nonlinear effects in asymmetric catalysis. Angew. Chem., Int. Ed. 2009, 48 (3), 456-494.

62. Johnson, D. W.; Singleton, D. A., Nonlinear effects in kinetic resolutions. J. Am. Chem. Soc. 1999, 121 (40), 9307-9312.

63. Gau, H.-M.; Lee, C.-S.; Lin, C.-C.; Jiang, M.-K.; Ho, Y.-C.; Kuo, C.-N., Chemistry of $\mathrm{Ti}(\mathrm{OiPr}) \mathrm{Cl}_{3}$ with chloride and oxygen-containing ligands: The roles of alkoxide and solvents in the six-coordinate titanium complexes. J. Am. Chem. Soc. 1996, 118 (12), 2936-2941.

64. Heathcock, C. H.; Buse, C. T.; Kleschick, W. A.; Pirrung, M. C.; Sohn, J. E.; Lampe, J., Acyclic stereoselection. 7. Stereoselective synthesis of 2-alkyl-3-hydroxy carbonyl compounds by aldol condensation. J. Org. Chem. 1980, 45 (6), 1066-1081.

65. Mukaiyama, T.; Stevens, R. W.; Iwasawa, N., Stannous triflate: a new aldol reaction via divalent tin enolates. Chem. Lett. 1982, (3), 353-6.

66. Cowden, C. J.; Paterson, I., Asymmetric aldol reactions using boron enolates. Organic Reactions, John Wiley \& Sons, Inc.: 2004; pp 3-191.

67. Xie, L.; Isenberger, K. M.; Held, G.; Dahl, L. M., Highly stereoselective kinetic enolate formation: steric vs. electronic effects. J. Org. Chem. 1997, 62 (21), 7516-7519.

68. Hoffmann, R. W.; Froech, S., Tandem aldol addition/allyl metal addition. Tetrahedron Lett. 1985, 26 (13), 1643-1646. 
69. Hoffmann, R. W.; Ditrich, K.; Froech, S., Stereoselective syntheses of alcohols, XXV. Generation of enol borates and their addition to aldehydes. Liebigs Ann. Chem. 1987, (11), 977-985.

70. Suginome, M.; Uehlin, L.; Yamamoto, A.; Murakami, M., A new look at boron enolate chemistry: Aminative C-C bond formation using diaminoboron enolate with aldehyde. Org. Lett. 2004, 6 (7), 1167-1169.

71. Brown, H. C.; Dhar, R. K.; Bakshi, R. K.; Pandiarajan, P. K.; Singaram, B., Major effect of the leaving group in dialkylboron chlorides and triflates in controlling the stereospecific conversion of ketones into either [E]- or [Z]-enol borinates. J. Am. Chem. Soc. 1989, 111 (9), 3441-3442.

72. Evans, D. A.; Chapman, K. T.; Carreira, E. M., Directed reduction of $\beta$-hydroxy ketones employing tetramethylammonium triacetoxyborohydride. J. Am. Chem. Soc. 1988, 110 (11), 3560-3578.

73. Roush, W. R., Concerning the diastereofacial selectivity of the aldol reactions of $\alpha$-methyl chiral aldehydes and lithium and boron propionate enolates. J. Org. Chem. 1991, 56 (13), 4151-4157.

74. Sakuma, K.; Gilchrist, J. H.; Romesberg, F. E.; Cajthaml, C. E.; Collum, D. B., Lithium bis(2-adamantyl)amide: Structure and reactivity of an extremely hindered lithium dialkylamide. Tetrahedron Lett. 1993, 34 (33), 5213-5216.

75. Hall, P. L.; Gilchrist, J. H.; Collum, D. B., Effects of lithium salts on the stereochemistry of ketone enolization by lithium 2,2,6,6-tetramethylpiperidide (LiTMP). A convenient method for highly E-selective enolate formation. J. Am. Chem. Soc. 1991, 113 (25), 95719574. 
76. Evans, D. A.; Dart, M. J.; Duffy, J. L.; Rieger, D. L., Double stereodifferentiating aldol reactions. The documentation of "Partially Matched" aldol bond constructions in the assemblage of polypropionate systems. J. Am. Chem. Soc. 1995, 117 (35), 9073-9074.

77. Jung, M. E.; Salehi-Rad, R., Total synthesis of auripyrone A using a tandem non-aldol aldol/Paterson aldol process as a key step. Angew. Chem., Int. Ed. 2009, 48 (46), 87668769.

78. Jung, M. E.; Chaumontet, M.; Salehi-Rad, R., Total synthesis of auripyrone B using a nonaldol aldol-cuprate opening process. Org. Lett. 2010, 12 (12), 2872-2875.

79. Evans, D. A.; Ng, H. P.; Clark, J. S.; Rieger, D. L., Diastereoselective anti aldol reactions of chiral ethyl ketones. Enantioselective processes for the synthesis of polypropionate natural products. Tetrahedron 1992, 48 (11), 2127-2142.

80. Chen, K.-M.; Hardtmann, G. E.; Prasad, K.; Repic, O.; Shapiro, M. J., 1,3-syn diastereoselective reduction of $\beta$-hydroxyketones utilizing alkoxydialkylboranes. Tetrahedron Lett. 1987, 28 (2), 155-158.

81. Poon, K. W. C.; Dudley, G. B., Mix-and-heat benzylation of alcohols using a bench-stable pyridinium salt. J. Org. Chem. 2006, 71 (10), 3923-3927.

82. de Lemos, E.; Porée, F.-H.; Bourin, A.; Barbion, J.; Agouridas, E.; Lannou, M.-I.; Commerçon, A.; Betzer, J.-F.; Pancrazi, A.; Ardisson, J., Total synthesis of discodermolide: Optimization of the effective synthetic route. Chem. Eur. J. 2008, 14 (35), $11092-11112$.

83. Mozingo, R., Org. Synth. 1941, 21, 15-17 (Coll. Vol. III 1955, 181-183).

84. Nishimura, S., Handbook of Heterogeneous Catalytic Hydrogenation for Organic Synthesis. John Wiley and Sons, Inc.: 2001; p 720. 
85. Frigerio, M.; Santagostino, M.; Sputore, S., A User-friendly entry to 2-iodoxybenzoic acid (IBX). J. Org. Chem. 1999, 64 (12), 4537-4538.

86. Boeckman, R. K.; Shao, P.; Mullins, J. J., The Dess-Martin periodinane: 1,1,1-triacetoxy1,1-dihydro-1,2-benziodoxol-3(1H)-one. Org. Synth. 2000, 77, 141-152. 